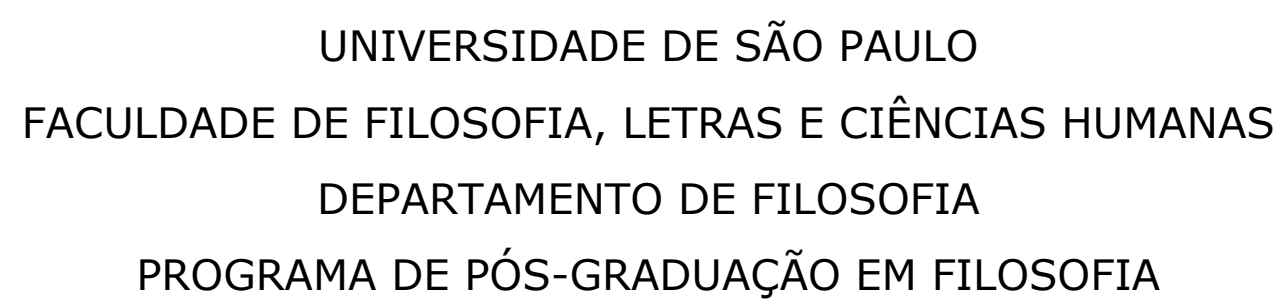

BENITO EDUARDO ARAUJO MAESO

Kafka: estética e política do estranhamento

Versão corrigida

São Paulo

2013 
BENITO EDUARDO ARAUJO MAESO

\section{Kafka: estética e política do estranhamento}

Versão corrigida

Dissertação apresentada à Coordenação de PósGraduação da Faculdade de Filosofia, Letras e Ciências Humanas (FFLCH) da Universidade de São Paulo (USP) para a obtenção do grau de Mestre em Filosofia.

Áreas de Concentração: Estética e Filosofia Política.

Orientador: Prof. Dr. Ricardo Nascimento Fabbrini.

São Paulo

2013 


\section{Folha de Aprovação}

Benito Eduardo Araujo Maeso

Kafka: estética e política do estranhamento

Dissertação apresentada à Faculdade de Filosofia, Letras e Ciências Humanas da Universidade de São Paulo para a obtenção do título de Mestre. Área de concentração: Filosofia (Estética e Política)

Aprovado em:

Banca examinadora:

Prof. Dr.

Instituição: Assinatura:

Prof. Dr.

Instituição: Assinatura:

Prof. Dr. Instituição: Assinatura: 
Para Patricia e Gabriel (Shoo e Cathu) 


\section{Agradecimentos}

Ao Prof. Ricardo Fabbrini, pela orientação segura e exigente, pelo voto de confiança em minha capacidade e no potencial do projeto, assim como pela extrema paciência nas correções de rota pelo caminho.

Ao Prof. Paulo Vieira Neto, pela amizade, incentivo, ideias, cafés, risadas e por acreditar que seria possível desde antes da ideia existir, mesmo quando eu achava o contrário.

Aos Profs. Celso Favaretto e Ricardo Musse, pelo estímulo e conselhos preciosos nas aulas e na qualificação.

Aos Profs. Marco Aurélio Werle, Vladimir Safatle, Christian Dunker e Nelson Silva Jr., pelas aulas, conversas, respostas e dicas durante o período letivo.

À Profa. Otília Arantes, pelo apoio e recomendações desde o início.

Ao Prof. Franklin Leopoldo e Silva, pelos insights para o fechamento do texto.

Às servidoras do Departamento de Filosofia da FFLCH, em especial à Maria Helena, "salvadora" dos orientandos.

Aos amigos e colegas de magistério no Integral e na UTFPR, em especial Tadeu, Sissi, Cláudio (grato pela revisão, meu nobre!), Jan, Júlio, Mariza, Fábio, Gastão e Marcelo Stein (e aos estagiários também).

Aos meus alunos de ensino fundamental, médio e graduação, em especial à turma T51-2009 da UTFPR, a armada que "cria conceitos".

Aos amigos e colegas da UFPR e da USP, em especial Gustavo (Mãozinha), Marcelo, Daniclei, Selma, Élisson, Glauber, Sarah, Vivi, Tina e Ajax (que salvou a turma inteira gravando as aulas).

Aos queridos Su Kardosh, Catarina, Maria Lúcia, Raul Neto e Daniel.

À adorada Camila Zupo, por muita coisa mesmo - e por grandes conversas num incrível sofá gigante.

E, principalmente, aos meus preciosos Patricia e Gabriel, por mais do que qualquer palavra possa expressar em um papel. 
A partir de certo ponto não há mais retorno. É este o ponto que tem que ser alcançado.

É ridículo como você coloca arreios em si mesmo para este mundo. (Kafka, aforismos 5 e 44)

Se eu pudesse acordar em outro lugar, numa outra época, seria outra pessoa? (Palahniuk, Chuck) 


\section{RESUMO}

MAESO, Benito Eduardo Araujo. Kafka: estética e política do Estranhamento. 2013, 181 p. Dissertação (Mestrado) - Faculdade de Filosofia, Letras e Ciências Humanas. Departamento de Filosofia, Universidade de São Paulo, São Paulo, 2013.

Esta dissertação tem como objetivo investigar de que forma a estrutura e a temática do texto de Franz Kafka, ao criarem um espaço de estranhamento na relação entre o leitor e o texto - uma sensação constante de que algo está "fora de lugar", constroem um campo de resistência política. Parte-se da análise dos elementos constitutivos da obra kafkiana, buscando localizar quais elementos efetuariam tal processo, assim como da análise dos trabalhos de pensadores como Adorno, Benjamin, Deleuze \& Guattari e outros sobre o escritor checo. Para tanto, será feito recurso livre à produção do autor, com destaque para a tríade $O$ Processo, $O$ Castelo e A Metamorfose, sem prejuízo de outros contos, novelas, cartas e anotações de seus diários. Também será buscada uma articulação dos temas inerentes à obra de Kafka com os conceitos principais dos filósofos citados. Como procedimento metodológico, estruturamos este percurso em quatro eixos principais: a escrita, o conceito de mímesis, o conceito de estranhamento (unheimlich) e as relações entre arte, política e sociedade, com especial foco no conceito de resistência, presente nas definições de Adorno e Deleuze sobre a arte. Assim, busca-se averiguar o caráter político dos textos de Kafka como alegorias da condição humana.

Palavras-chave: alegoria, estranhamento, Kafka, política, estética, Adorno, Deleuze. 


\begin{abstract}
MAESO, Benito Eduardo Araujo. Kafka: Aesthetics and Politics of the Uncanny. 2013. 181 p. Thesis (Master Degree) - Faculdade de Filosofia, Letras e Ciências Humanas. Departamento de Filosofia, Universidade de São Paulo, São Paulo, 2013.

This work aims to investigate the way Kafka's thematics and narrative structure builds the sensation of uncanny, misplacing and oddity between the reader and the story. Simultaneously, these characteristics of Kafka's work can build a political field of resistance. To achieve this goal and locate those elements in Kafka's literary corpus, an in-depth analysis of his works - letters, aphorisms, romances and short stories - is necessary, with special attention to The Process, The Castle and The Metamorphosis. Also, this work intends to establish a dialogue between Kafka's thematics and the concepts of Adorno, Benjamin, Deleuze and Guattari, among others. Four lines of force are the core of this thesis: Kafka's writing techniques; the concept of mimesis; the uncanny (unheimlich); and the linkage between art, poltics and society, with emphasis in the concept of "resistance" - which is present in Kafka's work and in Adorno's (and also in Deleuze's) definition of art. At last, what is the political status of Kafka's work as an allegory of human condition?
\end{abstract}

Keywords: allegory, uncanny, Kafka, politics, aesthetics, Adorno, Deleuze. 
LISTA DE ABREVIATURAS

\section{Textos de Adorno e/ou Horkheimer}

$\begin{array}{ll}\text { AsK } & \text { Anotações sobre Kafka } \\ \text { DE } & \text { Dialética do Esclarecimento } \\ \text { TE } & \text { Teoria Estética } \\ \text { DN } & \text { Dialética Negativa } \\ \text { ER } & \text { Eclipse da Razão } \\ \text { MM } & \text { Minima Moralia } \\ \text { TF } & \text { Terminologia Filosófica - Tomo } 1\end{array}$

\section{Textos de Deleuze e/ou Guattari}

$\begin{array}{ll}\text { K } & \text { Kafka: por uma literatura menor } \\ \text { MP } & \text { Mil Platôs } \\ \text { A-E } & \text { O Anti-Édipo } \\ \text { Conv. } & \text { Conversações } \\ \text { Cin. } & \text { Cinema: a imagem-tempo } \\ \text { LS } & \text { Lógica do Sentido } \\ \text { ID } & \text { A Ilha Deserta } \\ \text { OQF } & \text { O que é a Filosofia? } \\ \text { MK } & \text { Máquina Kafka }\end{array}$

\section{Obras, coletâneas ou textos de Kafka}

$\begin{array}{ll}\text { M } & \text { A Metamorfose } \\ \text { P } & \text { O Processo } \\ \text { C } & \text { O Castelo } \\ \text { NCP } & \text { Na Colônia Penal } \\ \text { D/A } & \text { O Desaparecido/ América } \\ \text { UMR } & \text { Um Médico Rural } \\ \text { CP } & \text { Carta ao Pai } \\ \text { C/F } & \text { Contemplação/O Foguista } \\ \text { AF/C } & \text { Um Artista da Fome/A Construção } \\ \text { EFK } & \text { Essencial Franz Kafka } \\ \text { S } & \text { Sonhos } \\ \text { PF } & \text { Parábolas e Fragmentos } \\ \text { D } & \text { Diários }\end{array}$




\section{SUMÁRIO}

1 INTRODUÇÃO

2 A NARRATIVA 17

$\begin{array}{ll}2.1 \text { Fantástica e realista? } & 17\end{array}$

$\begin{array}{ll}2.2 \text { Cinemática } & 21\end{array}$

2.30 narrador 26

2.4 Símbolo, alegoria e parábola 33

3 O MIMÉTICO $\quad 49$

$\begin{array}{ll}3.1 \text { Gesto } & 49\end{array}$

3.2 Mímesis $\quad 54$

3.3 Mutação/Sonho $\quad 59$

$\begin{array}{ll}3.4 \text { Humor } & 64\end{array}$

$\begin{array}{ll}3.5 \text { Horror } & 71\end{array}$

4 DAS UNHEIMLICHE

4.1 Do Sublime ao inquietante 76

4.2 Desumano e inumano 88

4.3 Duplos e séries $\quad 97$

4.4 O estranhamento de si 103

$\begin{array}{ll}4.5 \text { As sobras da razão } & 114\end{array}$

5 A ESTÉTICA POLÍTICA $\quad 121$

5.1 Literatura a contrapelo 123

$\begin{array}{ll}5.2 \text { Burocracia } & 134\end{array}$

5.3 O caso K.: estranhamento e arte política 144

$\begin{array}{lr}\text { EXCURSO: FORMA E ESTILO } & 159\end{array}$

$\begin{array}{lr}\text { REFERÊNCIAS } & 168\end{array}$ 


\section{INTRODUÇÃO}

Toda a arte de Kafka consiste em obrigar o leitor a reler ${ }^{1}$

A obra de Kafka nos conduz a um universo singular, no qual o espanto e a indiferença existem simultaneamente e a multiplicidade brota da padronização opressiva e da relação mecânica dos homens entre si e com o mundo.

Tentar desvelar este enigma é uma tarefa já tentada por muitos ${ }^{2}$, nem sempre com sucesso. Por isso, este trabalho não tem a pretensão de encontrar respostas definitivas sobre a narrativa kafkiana, mas a ambição - talvez ainda assim desmedida - de buscar jogar certa luz sobre sua natureza inquietante.

Para tal objetivo, elegeu-se esta inquietação, este estranhamento ${ }^{3}$ causado por Kafka como primeiro objeto de estudo, entendendo-o como parte de um processo histórico presente que é abordado pelo escritor e que encontra seu ápice nos dias de hoje: o estranhamento de si e sua relação com as alterações no tecido social que o originam ou decorrem dele.

\footnotetext{
${ }^{1}$ CAMUS, 2004, p. 89

${ }^{2}$ Esta riqueza crítica acumulada acaba por funcionar como uma faca de dois gumes: se fornece amplo material de pesquisa sobre as formas de entendimento da obra, por outro lado as discrepâncias entre os diversos enfoques acabam por dificultar sobremaneira a tentativa de aproximação em relação ao autor, visto por muitos como "difícil" e "hermético". Não seria de estranhar, então, que muito do hermetismo atribuído à obra de Kafka tenha origem exatamente nesta profusão de interpretações sobre seus textos. Escolhê-lo como foco de estudo, portanto, é lidar com um problema extra: a escolha correta de uma bibliografia, dentro do excesso de interpretações da obra kafkiana. A seleção de autores será então limitada para melhor delimitar o objeto da pesquisa.

${ }^{3} \mathrm{Em}$ muitos momentos os termos inquietante, inquietação, estranhamento e seus correlatos serão usados para se referir ao mesmo processo abordado neste trabalho. Tal flutuação semântica ocorre como efeito das diferentes traduções já dadas ao termo Unheimliche nas edições das obras freudianas em língua portuguesa (estranho, estranhamento, inquietante, inquietante estranheza e até mesmo sinistro), referindo-se ao texto Das Unheimliche (1919), crucial para o entendimento da categoria do estranhamento. Todos os termos se referem à sensação de desconforto que surge, na visão freudiana, como efeito do choque entre familiar e inesperado.
} 
Tal relação remeter-nos-ia ao conceito hegeliano de que a arte é uma das narrativas que dão sustentação a uma visão de mundo específica ${ }^{4}$ e localizada no tempo, permitindo o entendimento tanto do período histórico no qual foi produzida como do pensamento que norteia esse período. Assim, entender a estética do estranhamento na obra de Kafka significa averiguar a possibilidade de que, ao provocar esta inquietação, sua narrativa retire o leitor de sua zona de conforto e o leve à observação do mundo que o cerca sob um outro prisma.

Poderíamos dizer que o procedimento kafkiano de retratar o que há de "grotesco", "absurdo" e até "tragicômico" na existência cotidiana provoca intencionalmente no leitor um questionamento sobre o que 0 cerca, operando como forma de resistência política? E esta "ruptura estética" antecipa o conceito de arte como resistência ao mundo, abordado por autores como Theodor Adorno e Gilles Deleuze (que não à toa produziram obras lapidares sobre o autor $\left(\mathrm{checo}^{5}\right)$ ? Qual a tarefa do

\footnotetext{
${ }^{4}$ Hegel considera a Arte uma das metanarrativas, junto com a religião e a filosofia, que expressam as "necessidades e exigências mais elevadas do Espírito" e que permitem a compreensão tanto da época histórica onde ocorrem como do indivíduo em sua época, ou do "Espírito objetivo" de uma época. Pela arte o homem expressa sua consciência de si e do mundo, especialmente a lírica (prosa e poesia). Se a leitura comum sobre a proposta hegeliana aponta para as narrativas citadas como "camisas de força" sobre a compreensão da realidade, dando a entender que tais discursos moldam nossa visão de mundo, a inversão do conceito permite pensarmos que o mundo - a história enquanto presente/momento - é o que direciona e produz as narrativas, e estas depois acabam por perpetuar esta moldagem. A totalização não se daria na ação destas narrativas, mas estas seriam os objetos totalizados - gerados ou transformados em códigos para o funcionamento do humano no mundo, no momento histórico específico de sua existência e como forma de ultrapassamento das condições da vida prosaica, que já é em si componente da própria Arte: "Pois o conjunto do ânimo humano, com tudo o que o move no mais íntimo e o que nele é uma potência, cada sentimento e paixão, cada interesse profundo do coração [Burst] - esta vida concreta configura a matéria viva da arte e o ideal é sua exposição e expressão" (HEGEL, p.186). Já Adorno verá, ainda dentro de uma análise hegeliana, a Arte como um negativo do mundo, como espaço de contestação e crítica. Se a arte está relacionada ao espírito objetivo de uma época, o estranhamento, enquanto característica da obra kafkiana, está relacionado ao mundo que o cerca. O próprio escritor checo observa que a literatura tem menos a ver com história literária do que com a coletividade a qual esta literatura se relaciona.

${ }^{5}$ Anotações sobre Kafka, de Adorno, e Kafka - por uma literatura menor, de Gilles Deleuze e Félix Guattari, a serem referidas neste trabalho, respectivamente, pelas siglas AsK e K. Além destas obras, serão utilizados textos de Walter Benjamin, Gunter Anders, Georg Lukács e outros pensadores sobre o escritor checo. Tais conceitos e ideias servirão como referência (citados diretamente ou não no texto) para o desenvolvimento das hipóteses deste trabalho. Além desses autores, os textos de Modesto Carone e Susana Kampff-Lages,
} 
estranhamento na obra de Kafka? Arte como emancipação do homem, um diagnóstico da desesperança ou uma fuga do "real"?

O primeiro passo é analisar as circunstâncias que deram ensejo à criação da obra kafkiana e de que forma este estranhamento opera em seu interior.

Recorrendo a um conceito de Adorno, toda obra artística surge em relação próxima com a realidade histórico-social na qual foi engendrada. Porém, a arte opera não como replicação ou afirmação desta realidade e sim como sua negação: uma mensagem contrária que coloca "sob suspeita o idêntico" obras, a arte é uma crítica da feroz seriedade que a realidade impõe sobre os seres humanos ${ }^{7 \prime \prime}$.

Da mesma forma, não há para Adorno a dicotomia entre arte e sociedade, como se estas fossem categorias independentes que exigiriam uma mediação para sua integração e entendimento ${ }^{8}$. O movimento dialético buscado não tem como polos opostos arte e sociedade - sendo aquela a expressão do confronto das assincronias intrínsecas a esta: "não há mediação entre arte e sociedade, há mediação da sociedade na obra artística" $^{\prime \prime}$. A obra é produzida pelo pensamento de seu tempo, mas também o produz, em uma imbricação forma-conteúdo.

De certa forma, Adorno inverte o pensamento hegeliano: em vez de a arte ser um discurso-síntese de um mundo, cabe a ela ser o negativo deste mundo; ser o ponto de resistência à integração, possuir em si um

tradutores da obra de Kafka em língua portuguesa, terão papel importante no entendimento sobre as peculiaridades da escrita kafkiana. A divisão do trabalho por temas tem como objetivo facilitar a detecção - ou não - de uma relação entre as visões dos autores a partir da análise dos textos de Kafka.

${ }^{6}$ DN, p. 148. Para Adorno, a arte tem em si elementos da própria realidade que a gerou, da mesma forma que abre espaço para a crítica desta mesma realidade. Numa sociedade onde a padronização dos bens culturais é produtora e produto de uma padronização do indivíduo, a arte teria para si o papel de resgate da alteridade, da diferença, de uma nova configuração na relação eu-outro.

${ }^{7}$ TE, p.13

${ }^{8}$ Mediação que pode ser entendida, neste caso, como a existência de um terceiro elemento entre os dois polos. Tal elemento, supostamente neutro, estabeleceria uma relação entre os polos originais, operação realizada, por exemplo, pela Indústria Cultural como difusora e reprodutora de formas artísticas "aceitas" para as massas, com certo intuito pedagógico.

${ }^{9}$ COHN, 1986, p.20 
enigma cuja tentativa de interpretação provoca um deslocamento da visão habitual das coisas - visão à qual estamos acostumados por nossa imersão na realidade que a produz.

Tal análise nos levaria a questionar, em um primeiro momento, até que ponto a inquietação presente na obra kafkiana está relacionada à inquietação existente no mundo que a cerca. Seria esta característica resultante da inter-relação entre indivíduo, corpo social e realidade? Ou a expressão, por meio da literatura, da voz de um indivíduo ou grupo dentro de um conjunto maior - a sociedade?

Nas palavras do próprio Kafka, "a literatura tem menos a ver com a história literária do que com o povo ${ }^{10 " . ~ S e ~ u m ~ p o v o ~ s e ~ e x p r e s s a ~ p o r ~ m e i o ~}$ da literatura que cria, não é de todo descabido imaginar que os elementos presentes nesta produção literária também podem ser "localizados" na comunidade que esta retrata ${ }^{11}$.

Originário de uma família judia de classe média de Praga, Kafka teve contato - como se sabe - desde a infância com as culturas checa (seu local de nascimento), alemã (a cultura dominante à época na Europa Oriental) e judaica (apreendida pelas tradições familiares). Este caldeirão cultural, assim como sua relação conflituosa e tensa com o pai ${ }^{12}$, seu caráter reservado e uma certa dificuldade no relacionamento com as pessoas certamente tiveram papel na formação tanto de sua personalidade como de seu universo textual.

Mas não é possível reduzir sua obra apenas a estes fatores. O mundo que gera Kafka e que é por ele figurado de forma sui generis mostra dimensões mais complexas do que um simples decalque de elementos

\footnotetext{
${ }^{10}$ Nos Diários de Kafka, 25 de dezembro de 1911. p. 181. In K., p. 27

${ }^{11}$ O conceito deleuzoguattariano de "literatura menor" pode ser utilizado na compreensão de algumas características da produção kafkiana. O texto onde se encontra tal conceito é o já citado Kafka - por uma literatura menor, de 1975. Foram utilizadas as edições/traduções inglesa, espanhola e brasileira do texto. Por uma questão de economia e estilística, as referências à colaboração entre Deleuze e Guattari serão indicadas como "deleuzoguattariano(a)", pelos nomes dos autores ou simplesmente pelo nome de Deleuze, sem demérito ao caráter conjunto do trabalho dos autores.

12 Uma descrição - talvez exagerada ou dramatizada - desta relação é o tema de sua famosa Carta ao Pai, a ser abordada posteriormente.
} 
externos ${ }^{13}$. Isto posto, deve-se proceder a partir deste ponto em direção a um aprofundamento da compreensão sobre como tais efeitos ocorrem, investigando aspectos estruturais da narrativa.

Neste percurso, em alguns momentos será necessário um foco maior nos escritos dos analistas que compõem a vastíssima fortuna crítica sobre Kafka do que em seus próprios textos. Mas é exatamente desta forma, em uma tradição dialética ${ }^{14}$, que talvez seja possível avançar na compreensão das questões que o escritor checo suscita.

\footnotetext{
${ }^{13}$ A fortuna crítica sobre Kafka aponta para uma miríade de interpretações possíveis de sua obra, mas uma característica em comum a estas é a mensuração do efeito da realidade europeia dos anos 10 e 20 do século XX sobre a escrita kafkiana. Ao considerar, por exemplo, "A Construção" como o testamento literário de Kafka, CARONE (2011, pp.111114) aponta de maneira direta a relação entre o medo que ronda a toca e a ascensão do totalitarismo na Europa do período. O próprio texto em questão chegou a ser confiscado pelos nazistas em uma das inúmeras batidas policialescas na casa da última mulher de Kafka, Dora Diamant.

${ }^{14} \mathrm{Em}$ todas as acepções do termo "dialética", até mesmo se pensarmos que o método deleuziano de aproximação e ressonância com outros filósofos (o "pensar com" cf. MACHADO, 2009, passim) e sua articulação de conceitos e elementos de fora da tradição acadêmica podem ser, com alguma liberdade, pensados como "microdialéticas elevadas ao infinito", pois tais articulações não caminham para uma síntese que esgote o assunto, e sim para abrirem novos pontos de apoio (de forma positiva, mas mesmo assim com uma mecânica interna dialógica). Em música, a ressonância ocorre quando um emissor de ondas (a corda) vibra em uma frequência fantasticamente próxima (ou igual) à frequência natural de um instrumento. O corpo de um instrumento musical, um violão, por exemplo, é uma caixa de ressonância. As vibrações da corda entram em ressonância com a estrutura da caixa de madeira que "amplifica" o som e acrescenta vários harmônicos, dando o timbre característico do instrumento. Ou seja: parte-se de duas ou mais fontes sonoras que interagem de forma sistêmica com o objeto, gerando não apenas a amplificação da nota, como produzindo harmônicos (frequências múltiplas da nota principal, derivadas desta, que de certa forma a contém. Os harmônicos compõem a nota principal assim como são realçados, abafados ou criados por ela.). Na afinação de um instrumento musical, a técnica de batimento dos harmônicos acaba por gerar uma terceira onda resultante das duas ondas iniciais, de modo que o par de cordas está afinado entre si quando as ondas coincidem (se sintetizam), liberando toda a complexidade do campo harmônico - o timbre do instrumento. Analogamente, o conceito de dialética pode ser pensado de forma não totalizante ou diversa da síntese de opostos: para Engels, a dialética "não delimita de modo isolado os objetos, nem os toma como algo fixo e acabado, investiga os processos, a origem e o desenvolvimento das coisas e as insere em uma trama infinita de concatenações e de mútuas influências, em que nada permanece o que era nem como e onde existia" (MUSSE, 1997, p.43, grifo nosso). Já Horkheimer lembra que a dialética rejeita tanto o monismo como o dualismo filosóficos e, nessa dupla rejeição, resiste à sua própria imobilização, já que a hipostasia de um dos polos ou dos momentos do processo é abdicar da própria dialética. Assim, o chamado à multiplicidade e diferença característicos de Deleuze - o rizoma - podem ser vistos, de forma semelhante, como uma dialética da Diferença.
} 
Assim, o objeto principal deste estudo é averiguar se a obra de Kafka, por criar um espaço de estranhamento, possui uma dimensão de resistência política, assim como localizar quais elementos da obra efetuariam tal processo. Para tal investigação, estruturamos este percurso em quatro eixos principais a serem mapeados pela análise da produção do autor checo: a análise da narrativa kafkiana, o conceito de mímesis, o conceito de estranhamento (unheimlich ${ }^{15}$ ) e a relação entre estética e politica. Será feito recurso livre à produção kafkiana, com destaque para a tríade O Processo, O Castelo e A Metamorfose, sem prejuízo de outros contos, novelas, cartas e anotações dos diários do escritor.

${ }^{15}$ Cf. nota 3 desta introdução. 


\section{A NARRATIVA}

O estranhamento provocado pela obra de Kafka tem como primeiro motor a própria forma da escrita do autor: períodos longos, entremeados por vírgulas constantes e compostos por um léxico limitado, que é construído ao se tomar "ao pé da letra metáforas fossilizadas da linguagem corrente ${ }^{16 "}$. A "seleção dos detalhes ${ }^{17 "}$ por Kafka coloca em primeiro plano aquilo que é essencial, gerando um espaço entre $o$ que é descrito e o como algo é descrito. Lukács verá o mundo de Kafka como "a

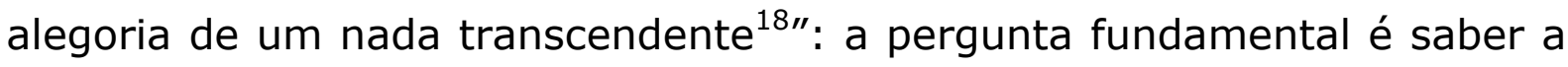
que este nada se refere e se há, na estrutura narrativa kafkiana, algum indício para localizar esta resposta.

\subsection{Fantástica e realista?}

A época que dá suporte à obra de Kafka é um tempo no qual esperanças e angústias conhecem novos limites: de Marx a Nietzsche, da Comuna de Paris aos germes do fascismo, o mundo que antecede o escritor de Praga é o tempo das revoluções, da ascensão burguesa, do surgimento da esquerda e da vida nas metrópoles.

Tais mudanças nas conformações sociais trazem uma nova sociabilidade, baseada nas distâncias cada vez maiores entre os componentes desta sociedade apesar de sua maior proximidade física: o trabalho e o capital se tornam elementos definidores da própria subjetividade, numa espécie de pragmatismo das relações sociais.

Também é uma época de experimentações artísticas e busca de novas linguagens, como o dadaísmo, o surrealismo, o surgimento do

\footnotetext{
${ }^{16}$ CARONE, 2011. In EFK., p.222

${ }^{17}$ LUCAKS, 1969, p. 84

${ }^{18}$ ibid., p. 86
} 
cinema e, no campo da literatura, o que se convencionou chamar de literatura especulativa ${ }^{19}$ ou fantástica (que tem entre seus expoentes nomes como Poe e Hoffmann), que soma elementos do arcaico - antigos medos e sonhos - ao que o novo tem de mais promissor e assustador ${ }^{20}$. Narrativas cujo centro abriga "a tentativa de criar realidades alternativas que vêm relativizar a nossa própria ao especular sobre a realidade, fornecendo paradigmas que relativizam as compreensões estabelecidas ${ }^{\prime 21}$.

Se admitirmos - com sérias ressalvas ${ }^{22}$ - a possibilidade de perfilar Kafka no terreno da literatura fantástica, que elementos de sua obra nos possibilitariam tal aproximação? Uma das características da literatura fantástica está no fato de que o que ela descreve, quando confrontado com nossa realidade, não pode ser explicado pelas leis aparentemente constantes que regem o "real". Um evento fantástico é aquele no qual há dúvidas se sua explicação se dá de forma lógica ou não. Para TODOROV,

Há um fenômeno estranho que se pode explicar de duas maneiras, por meio de causas de tipo natural e sobrenatural. A possibilidade de se hesitar entre os dois criou o efeito fantástico ${ }^{23}$.

Todorov observa, porém, que a história fantástica não deve soar como metáfora ou alegoria. Deve haver uma predisposição do leitor para negar a simples analogia e hesitar sobre a realidade do fato. Na obra

\footnotetext{
${ }^{19}$ CAUSO, 2003, p.32.

${ }^{20}$ No caso de Hoffmann, por exemplo, cujo livro "O Homem de Areia" é analisado por Freud no já citado Das Unheimliche ("O inquietante"), a antiga história da personagem que assustava as crianças que não queriam dormir é amalgamada com o fascínio pela tecnologia, na possibilidade da criação de um andróide.

${ }^{21}$ CAUSO, 2003, loc.cit.

${ }^{22}$ A problemática do fantástico na obra de Kafka não é nova e, de certa forma, se encontra superada. Todavia, o manejo de elementos do fantástico em suas obras pode ser interpretado como um procedimento do autor para mostrar o real. A discussão fantástico versus realismo já guardaria, em si, indícios da análise do estranhamento como dimensão estética e política da obra de Kafka.

${ }^{23}$ TODOROV, 2008, p. 31
} 
kafkiana, a naturalidade com a qual o "absurdo" é narrado colocaria o leitor neste ponto de hesitação.

Se partimos de pessoas que viram insetos ou animais falantes, em uma história como $O$ Veredicto este híbrido entre o "absurdo" e o dito "natural" está presente em uma situação quase cotidiana, na qual uma simples comunicação é o estopim para um conflito brutal entre Georg e seu pai.

Neste conto, o amigo de São Petersburgo, cuja existência é colocada inicialmente em dúvida pelo pai, acaba por ser retratado como um tipo de observador onisciente de tudo que acontece na vida do jovem Georg, pois o pai o informa sobre todas as atividades condenáveis realizadas pelo filho, como casar-se sem autorização, negligenciar o amigo e desrespeitar a autoridade do pai, além de tomar-lhe a frente nos negócios. Nas palavras do pai de Georg,

Como você hoje me divertiu quando veio perguntar se devia escrever ao seu amigo sobre o noivado! Ele sabe de tudo, jovem estúpido, ele sabe de tudo! Eu escrevi a ele porque você se esqueceu de me tirar o material para escrever! É por isso que há anos ele não vem, ele sabe de tudo cem vezes mais do que você mesmo, amassa sem abrir as suas cartas na mão esquerda enquanto com a direita segura as minhas diante dos olhos para ler. ${ }^{24}$

O desenlace, no qual o pai condena o filho a morrer afogado sentença cumprida obedientemente por este - leva o leitor ao questionamento sobre as razões da sentença: o drama familiar, elemento presente na literatura, evolui para algo que não é esperado - e mesmo que pensemos que Georg tem seu destino selado a partir do momento em que recebe a condenação, sobra a dúvida sobre qual a motivação real tanto do pai como do filho no caso.

Não se trata de simplesmente aplicarmos uma analogia edípica, visto que a mãe já está morta, mas de talvez levar ao extremo a 
possibilidade do conflito: o desenlace esperado ocorre, mas de uma forma inesperada. O fantástico na narrativa chama a atenção, segundo Carone, pela crescente deformação da realidade desde o momento em que Georg "sai do seu quarto e entra no quarto escuro do pai. O estranhamento consiste aqui na integração do que não é plausível num acontecimento cotidiano descrito com aparente naturalidade"25.

Paradoxalmente, tal recurso à imagética do fantástico é o que daria à obra de Kafka seu caráter mais realista. Devemos entender realismo, aqui, não como mímesis - o que será abordado posteriormente - mas como o que se mostra a partir da não-identificação, da fratura do aparente que é tomado como real. "Evidentemente não se trata do

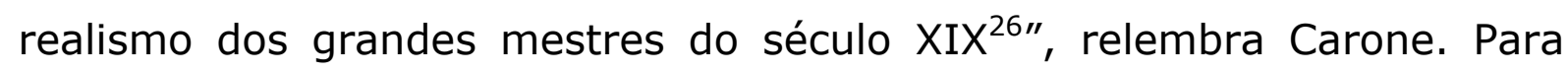
ele, o termo é entendido como o mostrar "no próprio corpo de obrasprimas como esta, as coisas como elas são e as coisas como elas são percebidas pelo olhar alienado. ${ }^{27 \prime \prime}$.

A observação de Benjamin sobre a obra de Picasso - que registraria "não as nossas formas, mas nossas deformidades ${ }^{28 "}$ - é aplicável também ao texto kafkiano. Por meio da imagética do fantástico surge uma realidade à qual, em circunstâncias normais, nos recusamos a enxergar.

É como se muita coisa tivesse sido negligenciada na defesa de nossa pátria. Até então não havíamos nos importado com isso, entregues como estávamos ao nosso trabalho; mas os acontecimentos dos últimos tempos nos causam preocupações $^{29}$.

Outra característica do fantástico - o caráter amedrontador - não seria, em um primeiro momento, plenamente aplicável ao "estranho inquietante": o estranhamento não produz pânico, mas um sentimento de

\footnotetext{
${ }^{25}$ CARONE, 2009, p.49

${ }^{26}$ ibid., p. 45

${ }^{27} \mathrm{Em}$ sua análise sobre o conto Na Galeria, que será abordado na sequência. Ibid., loc.cit.

${ }^{28}$ Ibid., p.37

${ }^{29}$ UMR, p. 24
} 
difícil definição (não capturável em sua totalidade pelos sentidos). Todavia, o conceito freudiano sobre o estranhamento opera uma clivagem entre o medo de algo não-familiar e o estranhamento propriamente dito: "O estranho é aquela categoria do assustador que remete ao que é conhecido, de velho, e há muito familiar" ${ }^{30 " . ~ O ~ t e m o r ~ c a u s a d o ~ p e l o ~}$ ressurgimento de algo familiar que foi reprimido é o que provoca a estranheza. Ou seja, o estranhamento surge de algo que remete diretamente à realidade - ou que remete à impressão emocional de alguma ocorrência real e familiar ${ }^{31}$.

\subsection{Cinemática}

O desvelar desta dimensão oculta do real pode ser investigado também pela mudança na relação estabelecida entre a obra e o seu receptor (ou público). Se em um teatro assistimos confortavelmente a tragédia que se descortina diante de nossos olhos - contemplando em segurança a loucura de Hamlet ou Lear - e em um livro nossa "imaginação" nos permite a identificação ou projeção no narrador - seja este o protagonista da história ou não - face aos textos do escritor checo podemos dizer que sua narrativa tem um quê de fílmica ${ }^{32}$. Suas descrições pormenorizadas assemelham-se a cenas pois permitem uma visualização completa do que ocorre no local e dos personagens que 0 compõem, mas interditam o movimento de identificação do espectador por meio do recurso ao inesperado. O inverossímil é descrito de forma absolutamente verossímil, com riqueza de detalhes.

\footnotetext{
${ }^{30}$ FREUD, 1985 , p. 87

31 Podemos dizer que há uma espécie de parentesco entre elementos do fantástico contemporâneo, conforme definido por SARTRE (2006, passim), e as características do estranhamento freudiano, notadamente no mecanismo de deslocamento, que "retira o fato da normalidade ao deformá-lo, ao transformá-lo, sem, no entanto, tirar-lhe a característica primordial" (SÁ, 2003. p. 69)

32 O que é coerente com a atmosfera cultural de sua época, como referenciado anteriormente. O cinema dava passos importantes em seu desenvolvimento e consolidação como linguagem artística à época de Kafka.
} 
Percorri o pátio mais uma vez; não via nenhuma possibilidade; distraído, atormentado, bati com o pé na frágil porta da pocilga que já não era usada fazia anos. Ela se abriu, foi e voltou, estalando nos gonzos. Veio de dentro um bafo quente e um cheiro como que de cavalos. Uma fosca lanterna de curral oscilava pendente de uma corda. Um homem acocorado no cômodo baixo mostrou o rosto aberto e de olhos azuis.

- Devo atrelar? - perguntou, rastejando de quatro para fora.

Eu não soube o que dizer e me inclinei só para ver o que ainda havia na pocilga. A criada estava ao meu lado.

- A gente não sabe as coisas que tem armazenadas na própria casa - disse ela e nós dois rimos.

- Olá irmão, olá irmã! - bradou o cavalariço e dois cavalos, possantes animais de flancos fortes, as pernas coladas ao corpo, baixando as cabeças bem formadas como se fossem camelos, saíram um atrás do outro, impelidos só pela força dos movimentos do tronco, através da abertura da porta que eles ocupavam por completo.

Mas logo ficaram em pé, altos sobre as pernas, o corpo soltando um vapor denso. ${ }^{33}$

A ação se passa à frente do leitor, que é como um coadjuvante na história: está ao lado das personagens, mas não tem poder de ação sobre o desenrolar da narrativa, ocasionando um choque disruptivo em relação à identificação que normalmente ocorre entre leitor e protagonista.

Em A Metamorfose, ao sabermos que na sala ao lado Grete e os pais de Gregor conversam, há um desejo de querer saber o que se passa, exatamente como Samsa expressa, mas permanece uma distância entre o que ocorre com ele e conosco.

Mas ao passo que não podia tomar conhecimento imediato de qualquer novidade, Gregor escutava muita coisa vinda dos quartos vizinhos, e onde quer que ouvisse vozes corria logo à respectiva porta e se espremia nela com o corpo todo. Especialmente nos primeiros tempos não havia conversa que de algum modo não tratasse dele, mesmo em segredo ${ }^{34}$.

\footnotetext{
${ }^{33}$ UMR, pp. 13-14. A descrição do que ocorre é profundamente pormenorizada, mesmo que o fato descrito seja em si inverossímil.

${ }^{34} \mathrm{M}$, pp. $39-40$
} 
Podemos até, de certa forma, dizer que ao abrir a porta e rever exatamente a mesma situação de castigo dos guardas Franz e Willem em O Processo, Josef $\mathrm{K}$. nos brinda com um flashback, não para que nosso entendimento sobre o que ocorre se aprofunde, mas para mostrar que há algo profundamente perturbador nesta repetição - o que não nos deixa sair completamente ilesos da situação.

Isso não significa que Kafka tenha adaptado sua prosa à narrativa da cinematografia nascente. Nas correspondências entre Kafka e Max Brod, assim como entre o autor e sua noiva Felice, os comentários sobre o cinema mostram a posição ambígua de Kafka em relação à nova arte e as transformações que ocorriam nos espaços urbanos e sociais ${ }^{35}$.

A correspondência deixa clara a convicção de Kafka sobre a necessidade de visitas mais demoradas e numerosas às salas de projeção para assimilar o que acontecia. Mas a discordância de visões entre Brod e Kafka (o primeiro considera o cinema uma extensão da literatura e o segundo criticava o caráter fugidio da imagem, pois os filmes ofereciam "agitação" em contraste com a calma contemplativa que admirava)

\footnotetext{
${ }^{35}$ Tal ambiguidade em Kafka apenas reforçaria, na visão deleuziana, o caráter político de sua literatura, enquanto imediatamente inserida no locus social que a suporta. O cinema, arte nascente à época e ainda em processo de definição de seu público, é visto pelo filósofo francês como portador de uma dupla mensagem, notadamente em sua intencionalidade política: se no cinema político tradicional "o público já estava lá" (DELEUZE, 1989. p. 216), ou seja, o espectador (sozinho ou coletivo) se reconhecia na obra, que tinha como objetivo a representação/captura de algo que já estava latente ou escancarado nas massas ou no povo - o cinema político moderno se dirige a um público ainda por vir, que ainda deve construir suas identidades, que busca forjar uma coletividade não por laços com o passado, mas abraçando o futuro. Analogamente, a literatura de Kafka se dirigiria a um povo ainda não detectado, imerso na coletividade. Seria um processo de invenção deste novo "devircomunidade" (o que nos remete a Blanchot e a Agambem) que irrompe pelas brechas do grupo maior ou consagrado. Não é um campo de representação de um povo ou indivíduo, mas de sua criação, assumindo que tanto o projeto coletivista como o individualista estão destinados ao fracasso e à incompletude.
} 
também não significa que a sétima arte não causou algum impacto sobre o escritor ${ }^{36}$.

A similitude entre a narrativa kafkiana e os planos cinematográficos em alguns momentos mostra que a efervescência cultural da época em Praga teve seu papel como elemento de composição na prosa do autor; mas é importante lembrar que não foram os escritores do século XIX e início do XX que adaptaram sua linguagem à do cinema, e sim o inverso: "os diretores do cinema é que usam técnicas da literatura de ficção 37 ".

Em Kafka, não ocorre uma simples equivalência da alternância literária entre primeira e terceira pessoas (intercalando os diálogos do protagonista com o pensamento do narrador) e a alternância entre a câmera subjetiva (a que emula o olhar da personagem) e a câmera objetiva (a que nos dá o plano geral): uma inversão como a operada no conto "Na Galeria" ${ }^{38}$, em que um único acontecimento é narrado de duas

\footnotetext{
${ }^{36}$ Segundo ZISCHLER (2005, passim), o romance incompleto "Ricardo e Samuel", escrito a quatro mãos por Kafka e Brod, possui referências diretas, do próprio punho de Kafka, a cenas de filmes assistidos por ele, como "A escrava branca", de 1911.

${ }^{37}$ ECO, 1994, p. 77

38 Segue-se na íntegra o conto "Na Galeria": "Se alguma amazona frágil e tísica fosse impelida meses sem interrupção ao redor do picadeiro sobre o cavalo oscilante diante de um público infatigável pelo diretor de circo impiedoso e de chicote na mão, sibilando em cima do cavalo, atirando beijos, equilibrando-se na cintura, e se esse espetáculo prosseguisse pelo futuro que se vai abrindo à frente sempre cinzento sob o bramido incessante da orquestra e dos ventiladores, acompanhado pelo aplauso que se esvai e outra vez se avoluma das mãos que na verdade são martelos a vapor - talvez então um jovem espectador da galeria descesse às pressas a longa escada através de todas as filas se arrojasse no picadeiro e bradasse o basta! em meio às fanfarras da orquestra sempre pronta a se adaptar às situações.

Mas uma vez que não é assim, uma bela dama em branco e vermelho entra voando por entre as cortinas que os orgulhosos criados de libré abrem diante dela; o diretor, que busca abnegadamente seus olhos, respira voltado para ela numa postura de animal fiel; ergue-a cauteloso sobre o alazão como se ela fosse a neta amada acima de tudo que parte para uma viagem perigosa; não consegue se decidir a dar o sinal com o chicote; afinal dominando-se ele o dá com um estalo; corre de boca aberta ao lado do cavalo; segue com o olhar agudo os saltos de amazona; mal pode entender sua destreza; procura adverti-la com exclamações em inglês; furioso exorta os palafreneiros que seguram os arcos à atenção mais minuciosa; as mãos levantadas, implora à orquestra para que faça silêncio antes do grande salto mortal; finalmente alça a pequena do cavalo trêmulo, beija-a nas duas faces e não considera suficiente nenhuma homenagem do público; enquanto ela própria, sustentada por ele, na ponta dos pés, de braços estendidos, a cabecinha inclinada para trás, quer partilhar sua felicidade com o circo inteiro - uma vez que é assim o espectador da galeria apoia o rosto sobre o parapeito e, afundando na marcha final como num sonho pesado, chora sem o saber." UMR, pp.22-23
} 
formas distintas - uma como desejo/esperança e outra como realidade objetiva - remete a um recurso de quebra de narrativa, ou "desnarração"39.

Se fosse possível relacionar a narrativa kafkiana ao foco de uma câmera cinematográfica, é mais fácil conceber tal relação como se a câmera - nosso olhar - estivesse logo atrás do protagonista e

${ }^{39}$ Conforme SILVA (2008, passim), a "desnarração é um termo que designa uma operação de contestação voluntária da narrativa. Com ela se tem em vista acabar com as diversas ilusões do espectador: ilusão realista e referencial da narrativa como reflexo do mundo real; ilusão da continuidade lógica pautada pela causalidade; ilusão de transparência, da neutralidade da narrativa". Ao analisar o filme Cidade dos Sonhos (Mullholland Drive), de 2001, dirigido por David Lynch, Silva considera que "uma narrativa fechada, com começo, meio e fim, na perspectiva de Lynch, apenas ilude que capta a realidade, pois a realidade em "estado bruto" não é captada. Com isso, a opção pela desnarração. Com ela, cabe à imaginação dar sentido ao lacunar, ao impreciso. Lynch reforça que narrar é de algum modo apelar para a imaginação. A desnarração quebra o hábito de "explicações" fechadas pelas imagens. Para ele, como na vida, a narrativa fechada ilude que se possa explicar o que está por trás dos "fatos brutos". (SILVA, pp. 1-2) A diferença entre a visão idealizada, ou onírica, do fato e a descrição da realidade objetiva, caracterizadas respectivamente pelo caráter condicional do primeiro trecho e indicativo no segundo trecho, são para CARONE (2009, passim) a indicação do realismo da prosa de Kafka, entendendo este termo como o mostrar, "no próprio corpo de obras-primas como esta, as coisas como elas são e as coisas como elas são percebidas pelo olhar alienado", conforme já dito. Para ele, se o leitor é capaz de ver no mundo do circo um "símile do próprio mundo em que vive, então a realidade 'propriamente dita' do primeiro parágrafo, em comparação com a realidade 'aparente' do segundo, expõe sibilinamente a ferida da alienação contemporânea" (Ibid., p. 44). Porém as causas desta ferida ou não são percebidas pelo público (os outros espectadores alheios ao que se passa, mas que são o real ponto de observação da história) ou são empurradas para um ponto em que parecem irreais (o modo subjuntivo), a despeito de sua existência real. A quebra narrativa entre as imagens descritas abre o espaço para que a nossa própria imaginação promova o desencantamento da ilusão que o primeiro trecho evoca, mostrandoo como "o real". Se todos na plateia enxergam a bela dama no cavalo, o jovem espectador da galeria é o único que vê o drama da proletária. A narrativa dita realista - e fechada - é o que cria a ilusão aos olhos do público, ainda conforme Carone. O que aproxima Lynch de Kafka, então, é a capacidade de desvelar o que está escondido a partir de um universo de imagens corriqueiras ou gastas: no conto, enquanto todos veem a bailarina e enxergam o clichê positivo da situação, o espectador anseia por interromper o drama que aparentemente só ele enxerga. Em Lynch, o mundo aparentemente perfeito que cerca a protagonista é revelado como falso - e todo o investimento emocional/libidinal dela se mostra vão. A partir das imagens mais comuns, do cotidiano ou do idealizado, irrompe a constatação de que aquilo não é exatamente como sua aparência nos diz, nos causando o estranhamento. Assim, a arte autêntica "conhece a expressividade do inexpressivo e sabe que só haverá experiência do real quando perdermos o medo de entrarmos em um teatro de ilusões" (SAFATLE, 2002, p.2). A própria linguagem utilizada possibilita este desvelamento: se Lynch se utiliza de clichês de narrativa em toda a primeira parte do filme para desmontá-los radicalmente a partir do ponto de inversão na cena do Club Silencio, o "alemão protocolar" esgrimido por Kafka - uma linguagem burocrática, comum, um tipo de clichê da dita língua maior - acaba por revelar significados mais profundos a partir do momento em que o leitor é exposto à obra. 
espiássemos por cima do ombro deste ${ }^{40}$, numa visão nem objetiva nem subjetiva. E nosso único poder nesta situação, por não sermos protagonistas nem simples espectadores, é o de estranharmos as imagens que surgem em nossa mente a partir disto ${ }^{41}$.

\subsection{0 narrador}

O sentimento de abandono do indivíduo perante a burocracia e as instituições, vistas como confusas e opacas, é tido por muitos como uma característica quase pessoal do autor checo - visível em suas relações pessoais e de trabalho, por exemplo. Porém, pode ser interpretado também como um efeito resultante de uma profunda modificação que Kafka promove na forma de se contar uma história: a reconfiguração da posição do narrador que, agora despido do poder de condução da história, não olha para os eventos com a segurança da distância existente no romance tradicional. Para Carone,

O narrador inventado por Kafka tem muito pouco a ver com o narrador do romance ou novela tradicional, que como

\footnotetext{
${ }^{40}$ Conforme será aprofundado no tópico O estranhamento de si. CARONE (2011) observa a mesma similitude de planos de visão em relação ao narrador de $A$ Metamorfose, que "se comporta como uma câmera cinematográfica na cabeça do protagonista" (EFK., p 214)

${ }^{41}$ A observação feita por Deleuze em relação à versão cinematográfica de O Processo dirigida por Orson Welles - remete-nos também à questão dos pontos de observação de uma narrativa. A relação dita arquitetural na construção narrativa de Kafka (visível nas proximidades e distâncias de $A$ Muralha da China ou $O$ Castelo e nas contiguidades e amplitudes de O Processo) é comparada por Deleuze à composição das cenas por Welles, construída pelo uso de plongées e contre-plongées (de cima para baixo e de baixo para cima, respectivamente) e grandes planos abertos, com ampla profundidade de campo e tomadas feitas com o uso de lente grande angular. A cena do corredor que leva ao quarto de Titorelli, dos "Iongínquos e contiguidades repentinas" (K., p.112) proporciona a percepção deste deslocamento constante no ponto de observação tanto na cena do filme como no livro. Mas a análise deleuziana da construção arquitetural existente dos textos de Kafka também nos remete, de forma inusitada, a um paralelo com o conceito de ruína em Benjamin e Adorno. Quando Deleuze aponta que Kafka teria sido um dos primeiros a tomar consciência do problema histórico da penetração mútua das burocracias do passado e do futuro, dos "arcaísmos com função atual e as neoformações" (K., p.110), é possível vermos isso como a busca por analisar de que forma os elementos do passado ainda se mostram operantes no presente, seja como denúncia ou crítica; ou ainda como eco ou rememoração.
} 
sabemos se caracteriza sobretudo pela onisciência. Isso quer dizer que o narrador tradicional, pré-kafkiano, não só tem acesso imediato à intimidade mais profunda dos seus personagens como também dispõe de uma visão panorâmica do conjunto da história que está narrando - embora se comporte como se estivesse contando esta história sem ter conhecimento prévio de seus desdobramentos ou do seu desfecho $^{42}$

Um efeito singular que isto provoca é o de nos empurrar a uma posição no mundo descrito, sem que ao mesmo tempo façamos parte dele: um deslocamento de ponto de vista em relação à narrativa-padrão da literatura, notadamente a do romance. O quadro que as palavras formam, em seu conjunto, se encaminha em direção a um ponto que parece estar fora da relação entre o que está enunciado (ou escrito), o sujeito de enunciação (aquele que diz o que ocorre) e o sujeito do enunciado (aquele de quem se diz algo). Esta experiência de deslocamento coloca o observador e o narrador dentro da cena, não como o centro dela, mas sim desconhecendo causas e descobrindo consequências enquanto o processo se desenrola: existem na obra e através dela, em uma posição incerta, tão jogados dentro das situações quanto as personagens.

Isto gera a necessidade de aceitarmos o que é dito na narrativa como verdadeiro - não por que tenhamos certeza disso, mas sim por não termos nenhum referencial anterior que ateste a validade ou não do que é dito. Não é possível termos certeza de que "alguém certamente havia caluniado Josef $K$, pois uma manhã ele foi detido sem ter feito mal algum ${ }^{43 "}$. Porém isto nos é dado a priori e não há outra solução a não ser aceitar esta premissa como verossímil, normal até, assim como a de que um homem possa acordar, um belo dia, transformado em inseto:

Em Kafka, o inquietante não são os objetos nem as ocorrências, mas o fato de que as criaturas reagem a elas

\footnotetext{
${ }^{42}$ CARONE, 2011, p.16.

${ }^{43}$ Frase de abertura de $O$ Processo
} 
descontraidamente, como se estivessem diante de objetos e acontecimentos normais. Não é a circunstância de Gregor Samsa acordar de manhã transformado em barata, mas o fato de não ver nisso nada de surpreendente - a trivialidade do grotesco - que torna a leitura aterrorizante. Esse princípio, que se poderia chamar de princípio da explosão negativa, consiste em não fazer soar sequer um pianíssimo onde caberia um fortíssimo: 0 mundo simplesmente conserva inalterada a intensidade do som. De fato, nada é mais espantoso do que a fleuma e a inocência com que Kafka entra nas estórias mais incríveis. ${ }^{44}$

De certa maneira, isso nos coloca em posição de "risco" perante o real: assumindo-se que o estranhamento surge daquilo que nos é mais cotidiano ou familiar ${ }^{45}$, podemos deslocá-lo para além da obra, em direção ao que nos cerca - com a diferença de que não é possível usar o recurso à suspensão da descrença ${ }^{46}$ como saída conciliatória.

A ambiguidade que experimentamos ao ver ambientes familiares e ao mesmo tempo aterrorizantes nas obras acabaria por nos levar a perceber relações similares nos ambientes que nos cercam no mundo? Não é estranho que isso ocorra. Se em vez de seguirmos o que é dito pelo sujeito de enunciação (tradicionalmente o narrador que produz o sentido do texto) voltarmos nosso foco para o que é enunciado, não identificaríamos o narrador como nossa contraparte na obra, mas aquilo que é descrito seria identificado com o que nos cerca.

Poderíamos arriscar um paradoxo e dizer que a obra de Kafka, o maior 'narrador' moderno, segundo Benjamin, representa uma 'experiência' única: a da perda da experiência, da desagregação da tradição e do desaparecimento do sentido primordial. Kafka conta-nos com uma minúcia extrema, até mesmo com certo humor, ou seja, com uma dose de jovialidade (Heiterkeit), que não temos

\footnotetext{
${ }^{44}$ ANDERS, 2007, pp 19-20

${ }^{45}$ Conforme será visto no capítulo 4.1

${ }^{46}$ Entende-se, aqui, "suspensão da descrença" como a aceitação das premissas de uma obra de ficção como "verdadeiras", mesmo que sejam por demais fantásticas ou contraditórias. Por exemplo, para que possamos entrar no universo dos contos infantis e frui-lo é necessário aceitarmos a existência de animais falantes, casas com pernas de avestruz, unicórnios e dragões.
} 
nenhuma mensagem definitiva para transmitir, que não existe mais uma totalidade de sentidos, mas somente trechos de histórias e de sonhos. Fragmentos esparsos que falam do fim da identidade do sujeito e da univocidade da palavra, indubitavelmente uma ameaça de destruição, mas também e ao mesmo tempo - esperança e possibilidade de novas significações $^{47}$

Aquilo que é inquietante pode ser entendido como o que provoca a revelação de uma diferença, uma fratura no tecido aparentemente coeso no qual estamos, permitindo que enxerguemos para além dele. Este processo pressupõe ter que lidar com um outro, uma alteridade. É possível então estabelecer paralelos entre a narrativa kafkiana e este processo, pois ambos não consistem em isolamento ou aceitação e sim em um confronto do qual surge uma visão deste real ${ }^{48}$.

${ }^{47}$ GAGNEBIN, in BENJAMIN, 1985, p. 18. A questão da dissolução da identidade do sujeito na obra de Kafka será abordada no transcorrer do trabalho, notadamente no tópico Desumano e Inumano.

${ }^{48}$ A pergunta aqui pode ser resumida em definirmos qual ou quem é esse outro presente na literatura de Kafka. Uma abordagem possível e que proporciona um interessante debate está contida no conceito de "literatura menor", aplicado por Deleuze e Guattari à obra de Kafka. Se, conforme os autores franceses, "maior", ou majoritário, se refere a processos relacionados à criação de padrões fixos e gerais, que funcionam como regras para o todo, o "menor" ou minoritário define aquilo que se desvia do padrão e que se volta contra a configuração destes padrões abstratos que caracterizam o "maior". Para Deleuze, o maior, exatamente por esta caracterização, se refere a um nada ou "ninguém", pois induz o mundo a se ajustar a um modelo que não pode existir de forma concreta. Em contrapartida, o menor é encontrado - ou se expressa - nos momentos concretos em que nos desviamos deste padrão, sendo um tipo de enunciação coletiva surgida da constatação inicial de que, no modelo maior, esta homogeneidade não existe na realidade: "Pois a maioria, na medida em que é analiticamente compreendida no padrão abstrato, não é nunca alguém, é sempre Ninguém - Ulisses - ao passo que a minoria é o devir de todo o mundo, seu devir potencial por desviar do modelo. Há um "fato" majoritário, mas é o fato analítico de Ninguém que se opõe ao devir-minoritário de todo o mundo. É por isso que devemos distinguir: o majoritário como sistema homogêneo e constante, as minorias como subsistemas, e o minoritário como devir potencial e criado, criativo." (MP, v2. p.105). Logo, o "outro" em questão poderia ser tanto a constatação de que tais modelos maiores ou molares são vazios - o que nos colocaria frente à dificuldade do reconhecimento de si dentro do modelo-padrão do Eu na sociedade - como também que o menor/minoritário pode ser entendido como um campo de experimentação, expressão e criatividade para aqueles que, espremidos por todos os lados por modelos maiores, não encontrariam forma de delimitar um espaço onde poderiam ser parte de algo maior já dado (o "povo"). A obra de Kafka, assim, contém tanto aquilo que a fortuna crítica chama de "abandono de si" como a força de vocalizar um "eu" feito a partir de uma coletividade que ainda não encontrou espaço para se pronunciar. Como, na visão deleuziana, o real nunca está terminado, sendo uma série perpétua e mutável de interpretações e forças que se entrecruzam e se produzem simultaneamente, a 
O efeito de estranhamento torna possível tratar o ato de viver e a relação com o semelhante como um problema filosófico: o ver-se ou colocar-se em uma posição que não a sua exige uma reflexão sobre a natureza deste outro. Esta dialética viver/pensar se processa em um movimento entre o sujeito e o mundo que o cerca: aquilo que lhe causa o estranhamento incita perguntas sobre o que antes parecia banal.

Muitos sistemas filosóficos e de pensamento colocam as respostas a serem obtidas como o mais importante, mas a prosa de Kafka mostra não a irrelevância da pergunta, mas sim a imprecisão ou ausência de respostas. O que ele descreve é, ao mesmo tempo, próximo e distante, familiar e impossível ${ }^{49}$. Uma narrativa que expõe, a cada diálogo, a incomunicabilidade entre o Eu e o Outro, não porque os personagens sejam impedidos de se expressar - mesmo que seja por guinchos ou sons intraduzíveis, como Gregor Samsa - mas sim pela incapacidade de se fazerem entender. Assim, evidencia-se a incompreensibilidade entre os polos dessa dialética.

Mas esta dificuldade de comunicação não se dá em relação a uma categoria transcendental, porém ao que é contingente ou quotidiano. É

obra kafkiana acaba por operar diretamente neste processo/mecanismo por ter a capacidade de invenção deste Outro. Kafka não escreve em seu nome, e sim em nome dos judeus checos de Praga do início do século XX. No limite, a obra dele é a obra deles. "O autor da literatura menor não é, estritamente, um sujeito, mas um evento ou singularidade, um 'foco de criação' composto". (THOBURN, 2003, p.51). A letra K não é, então, a inicial do nome do escritor, mas a deste sujeito de enunciação que ganha voz por meio dele - um sujeito composto e mutável nas reconfigurações que este grupo experimenta em sua relação com os demais grupos e com os fatores molares. O autor não é um gênio inatingível nem sua obra um produto autônomo em relação ao ambiente e comunidade. $O$ narrador está tão imerso nas situações quanto o protagonista, visto que não há separação entre forma da obra, significado e sujeitos de enunciado e enunciação, o que sugere uma aproximação com a indissociabilidade entre forma, conteúdo e sociedade na obra de arte, voltando ao terreno adorniano.

49 De acordo com GAGNEBIN (2007, p.68), a dialética próximo-distante contém em si a relação entre distância e inatingibilidade/independência, associada diretamente ao Eros e ao transcendente. $O$ próximo está ligado à percepção do sensível. Se as mudanças nesta relação dialética ocorridas na sociedade alteram a dinâmica entre os polos deste sistema, a mudança na configuração do narrador promovida por Kafka leva a um ponto além da simples aproximação entre a obra de arte e sua imagem aurática, dessacralizando-a. $\mathrm{O}$ autor checo cria novas relações auráticas a partir de uma aproximação excessiva com o sensível, com o real, o que vai ao encontro da ideia de aproximação entre o sublime e o prosaico. 
nas pequenas observações e frases de cada personagem que surgem as imagens mais irreais e simultaneamente mais possíveis. Pela proximidade inquietante, o pasmo e o assombro se transmutam em incômodos.

Kafka não se conforma ao mundo, não aceita como inevitável o que descreve. Neste sentido, sua prosa não está carregada de fatalismo, mas de perplexidade diante de situações nas quais o protagonista de suas histórias é colocado à sua revelia e, enquanto está mergulhado nelas, tanto ele como o leitor compartilham a sensação de não pertencerem àquele universo, como se tudo transcorresse em uma dimensão inverossímil. Um exemplo é a segurança e até o pouco caso de Josef $\mathrm{K}$. em relação ao processo: ele não crê, em muitos momentos, que aquilo tenha a ver com ele, tanto que a partir de um determinado instante sua preocupação passa a ser não mais saber do que é acusado e sim quem o acusa. Porém, o processo continua a transcorrer até seu fim anunciado, com K. sendo executado "como um cão".

Analogamente, o homem contempla o mundo que o cerca - e este mundo, para ele, é similar a um sonho, no qual não há relação de causa e consequência entre os atos. O indivíduo é dominado por aquilo que ele mesmo cria. Mas a vida continua, independentemente dele tomar consciência disso ou não. O fato de Samsa ou o agrimensor K., os protagonistas, morrerem não significa o fim das obras $A$ Metamorfose ou O Castelo; haja vista que a história continua, inclusive para o leitor: uma bela metáfora para o fato de que o mundo continua a existir sem nós.

As distâncias existentes ou construídas por Kafka em relação ao mundo que o cerca - e a reconfiguração da relação entre autor-obra-leitor que decorre disso - fascinam ao mesmo tempo que provocam um profundo incômodo, em um ponto externo ao texto e ao leitor, mas que se dá no mundo ${ }^{50}$. A sobriedade e a literalidade de Kafka ao descrever tais

\footnotetext{
${ }^{50}$ Conforme SCHOLLHAMMER (2002, pp. 59-70), "nas leituras de Kafka feitas pelo escritor e teórico francês Maurice Blanchot, nas quais Deleuze e Guattari se inspiraram diretamente, esta renúncia se dá em primeiro lugar como uma passagem do "eu" ao "ele". Acontece pela primeira vez de maneira notável no conto $O$ Veredito, e não só expressa o esvaziamento do íntimo "eu" numa terceira pessoa "ele", mas também a emergência de um "neutro" que se
} 
cenários provocam o estranhamento no leitor em decorrência da dificuldade em apreender o sentido do que é narrado, assim como da sensação de deslocamento em relação ao que se passa na narrativa. Ao mesmo tempo, o estranhamento - em sua acepção filosófica - surge a partir da leitura, pois nos descobrimos em uma posição na qual é imperativo realizar o questionamento, análoga ao Verfremdungseffekt buscado por Brecht, pois assim como nas peças deste, o espectador (o leitor) é impelido a assumir uma posição crítica e de certo distanciamento em relação ao que presencia ${ }^{51}$.

Mas se Brecht dá ao espectador o poder de julgar a ação que é representada, Kafka mantém a si e ao leitor em uma posição de suspeição em relação ao que acontece, como se a crítica resultasse da constatação da existência deste mundo opaco e impenetrável. Só é possível um julgamento ou entendimento sobre o narrado se o leitor sair de sua passividade e alienação.

Não é possível sair incólume após uma leitura de Kafka. Ao estranharmos a cisão apresentada pelo autor entre o protagonista e seu mundo, somos confrontados com nossa própria cisão entre existência e estrutura social. O leitor contempla de fora e ao mesmo tempo está imerso no mundo, como Gregor Samsa eternamente preso no quarto enquanto tudo se passa nos ambientes contíguos, mas nem por isso

instala no intervalo indeterminado entre sujeito de enunciação e sujeito do enunciado. 0 "neutro" vem de uma zona indiscernível entre o "eu" e o "ele", da qual transparece aquilo que Blanchot denomina o "Fora" da literatura. Na leitura de Deleuze e Guattari, o "Fora" é o lugar da multidão, isto é, de uma vitalidade anônima e de intensidades sem sujeito, constituído de puras hecceidades, blocos de perceptos e afetos, como um avesso a partir do qual e em direção ao qual a língua e as práticas culturais e sociais se articulam". (ibid., p. 65). A posição do narrador de Kafka pode ser entendida tanto como um ponto externo ao sujeito do enunciado e o sujeito de enunciação como a coincidência entre eles. Para Deleuze, Kafka opera nas cartas uma inversão entre o sujeito de enunciação (forma da expressão) e sujeito do enunciado (forma do conteúdo da carta), de modo que este último passa a ser o motor do fluxo epistolar. O assunto ganha importância frente aos interlocutores e o "intercâmbio ou inversão da dualidade dos sujeitos (...) produz um desdobramento", um duplo que posteriormente surgirá com mais força em outras obras, como O Desaparecido e O Veredicto. (K., p. 31 - ed. EUA)

51 Porém, é necessário dizer que o estranhamento em Kafka não possui o caráter de pedagogia de massas que o distanciamento cumpre na obra brechtiana. Esta diferença de mecanismo é, possivelmente, a causa maior da insatisfação de Brecht e de Lukács com Kafka. 
deixando de estar presente em todo o processo ${ }^{52}$. Tanto na realidade do escritor checo como na nossa, o fato de a vida transcorrer apesar de todos os impeditivos é em si o mais estranho:

O "absurdo" em F. Kafka rejeita todas as formas de "alienação", seja a família, profissão, dinheiro, sistemas filosóficos, religião e o patriotismo. Elas nada podem contra o "escândalo" que consiste no simples existir ${ }^{53}$.

\subsection{Símbolo, alegoria e parábola}

Em seu ensaio sobre Kafka ${ }^{54}$, Adorno revela qual é, em sua visão, a chave para o entendimento do autor checo: "insistir nos aspectos que dificultam o enquadramento e que, por isso mesmo, requerem interpretação ${ }^{55 " .}$ A recusa em ser absorvido facilmente. Aquilo que nos obriga a interrogar o mundo e desnudar seus paradoxos, escondidos por baixo de um manto de aparente coerência. O não-enquadramento ao qual o filósofo se refere remete à necessidade de ruptura do sempre-igual para o resgate da autonomia do pensamento. É daí que vem a "força de maelstrom ${ }^{56 "}$ da obra do escritor checo, segundo Adorno.

Colocar a obra kafkiana em rótulos ou escolas, o "conforto no desconfortável que o rebaixa a escritório de informações sobre a condição

\footnotetext{
${ }^{52}$ No conceito de literatura menor, conforme DELEUZE, "o campo político contaminou todo enunciado. Mas sobretudo, ainda mais, porque a consciência coletiva ou nacional está "sempre inativa na vida exterior e sempre em vias de desagregação", é a literatura que se encontra encarregada positivamente desse papel e dessa função de enunciação coletiva, e mesmo revolucionária: é a literatura que produz uma solidariedade ativa, apesar do ceticismo; e se o escritor está à margem ou afastado de sua frágil comunidade, essa situação o coloca ainda mais em condição de exprimir uma outra comunidade potencial, de forjar os meios de uma outra consciência e de uma outra sensibilidade" (K, p.27). O escritor acaba por amplificar esta nova consciência.

53 TRAGTENBERG, 1962.

54 "Anotações sobre Kafka", in Prismas - Crítica da Cultura e da Sociedade. Já referido como AsK.

${ }^{55}$ AsK, p. 239

${ }^{56}$ ibid., loc.cit
} 
eterna ou atual do homem ${ }^{57 "}$ é, para ele, uma tentativa de bloquear este potencial de ruptura. Por isso, todo o início de seu ensaio sobre Kafka traz a tentativa de libertar a obra do escritor checo das interpretações de cunho existencialista ${ }^{58}$, psicologizado e teológico, como se estas, ao assinalarem a presença de elementos tais na obra, acabassem por oferecer uma falsa solução ao seu "enigma", restringindo seu entendimento apenas a estes elementos (existentes, por certo, mas que não são suficientes para nos fornecerem, sozinhos, a chave para elucidar o autor).

A distinção entre símbolo e alegoria ${ }^{59}$, salientada pelo filósofo, é crucial para a compreensão de seu pensamento. Kafka não escreve A querendo dizer $B$. Ele quer nos levar ao ponto $B$ a partir do efeito que $A$ nos provoca. Não é uma obra de conciliação, e sim de ruptura.

Cada frase é literal, e cada frase significa. Esses dois aspectos não se misturam, como exigiria o símbolo, mas se distanciam um do outro, e o ofuscante raio da fascinação surge do abismo que se abre entre ambos. Apesar do protesto de seu amigo, a prosa de Kafka se alinha com os

\footnotetext{
${ }^{57}$ ibid., loc.cit

${ }^{58}$ Notadamente a de Max Brod, as leituras místico-teológicas de Scholem e o materialismo histórico de Brecht.

59 Segundo GADAMER (2009, p.69), "símbolo é a coincidência do sensível e do nãosensível; alegoria é uma referência significativa do sensível ao não-sensível". A distinção fundamental entre a alegoria e o símbolo foi estabelecida durante o Romantismo, em Coleridge no Statesman's Manual (1816) e em especial com Goethe e Schlegel. Para Goethe, "a simbólica [die Symbolik] transforma o fenómeno em ideia, a ideia em imagem, e de tal modo que na imagem a ideia permanece sempre infinitamente eficaz e inatingível e, ainda que pronunciada em todas línguas, continuaria a ser indizível. A alegoria transforma o fenômeno num conceito, o conceito em imagem, mas de tal modo que na imagem o conceito permanece limitado e suscetível de ser completamente apreendido e usado, e pronto para ser expresso por essa mesma imagem" (GOETHE, 1992, pp. 188-189). Para o escritor de Werther, o símbolo é dotado de maior amplitude de significação em relação à alegoria, esta uma mera tradução de ideias abstratas, ao passo que o símbolo parte sempre de imagens poéticas para construir a sua significação final. Já Hegel se contrapõe ao princípio de Schlegel, que defendia que toda a obra de arte devia ser uma alegoria. Para Hegel, tal só seria possível se significar que toda obra de arte deve representar uma ideia geral e implicar uma significação verdadeira, visto que a alegoria é "um modo de representação secundária tanto no conteúdo como na forma e só de um modo imperfeito corresponde ao conceito de arte" (HEGEL, 2001, p. 224).
} 
proscritos também por buscar antes a alegoria do que o símbolo ${ }^{60}$.

A alegoria, como figura de linguagem, pode ser definida como uma metáfora contínua, na qual um enunciado passível de leitura imediata transmite um ou mais significados diferentes do que a leitura literal possibilita. Tal processo faz o receptor da mensagem criar ou inferir um segundo enunciado, apropriado ao contexto apresentado na narrativa, que mantenha uma relação de similaridade com o primeiro ${ }^{61}$. Toda alegoria, para fazer sentido, precisa estar inserida em um contexto. Toda alegoria alega algo, enuncia um discurso, um conceito e se refere a um fato.

${ }^{60}$ AsK, p. 240-241. Adorno parte da visão do símbolo e da alegoria de BENJAMIN (1984, pp. 187-188): "a medida temporal da experiência simbólica é o instante místico, na qual o símbolo recebe o sentido em seu interior oculto e por assim dizer, verdejante. Por outro lado, a alegoria não está livre de uma dialética correspondente, e a calma contemplativa, com que ela mergulha no abismo que separa o Ser Visual e a Significação, nada tem da autossuficiência desinteressada que caracteriza intenção significativa, e com a qual ela tem afinidades aparentes". Ou seja, a alegoria reveste-se de símbolo, mas não é símbolo. Benjamin enumera dois tipos de alegoria: a "cristã", que se atesta no drama barroco e que nos dá a visão da finitude do homem na absurdidade do mundo, e a "moderna", atestada na obra de Baudelaire, colocada ao serviço da representação da degenerescência e da alienação humanas. Desta forma, a alegoria assume o papel de revelação de uma verdade oculta, pois não representa as coisas tal como elas são, mas pretende antes dar-nos uma versão de como foram ou podem ser. A alegoria é temporal e aparece como um fragmento arrancado à totalidade do contexto social; o símbolo é essencialmente orgânico. Para Benjamin, a alegoria se encontra "entre as ideias como as ruínas estão entre as coisas" (ibid., p.198). Por isso ele fala da alegoria como expressão da melancolia: o objeto deixa escapar a vida, fixado para a eternidade. Todo o sentido do objeto deriva exatamente de sua alegorização.

61 Os ditados populares são exemplos tradicionais de alegorias. Como exemplo, uma expressão como "água mole em pedra dura, tanto bate até que fura" possui três níveis de enunciação: o primeiro (alegórico) é o próprio ditado. O segundo (enunciado substituído pela alegoria) tem como mensagem principal 'não desista!'. O terceiro, um enunciado genérico que permite a aplicação da alegoria em diferentes casos, pode ser lido como 'a perseverança quebra lentamente as resistências'. Considerando que Kafka mostra especial predileção por usar ditados ao pé da letra, pode-se dizer que o que ocorre é uma inversão do processo alegórico, no qual os enunciados coincidem entre si. Uma alegoria com semântica aberta. Cabe a quem lê a obra efetuar a substituição do enunciado alegórico, determinar a que ele se refere. Ao seguirmos tal raciocínio, a questão que se coloca é perturbadora: e se as alegorias não estão realmente na obra de Kafka, mas são "colocadas" ali por nossas leituras? E se Kafka escreveu ficção literal (isto é, a ser interpretada ao pé da letra) e quem enxerga sua obra como alegórica são os leitores? O reverso não é menos perturbador: a escrita alegórica kafkiana sendo interpretada de forma literal. A hipótese da literalidade alegórica caminha com seu contrário, a alegoria "realista". Mais sobre tal possibilidade será abordado no tópico Humor. 
Porém, na alegoria kafkiana não há uma determinação exata do contexto no qual ela se aplica. É uma alegoria de que, afinal? A delimitação do objeto ao qual esta alegoria se refere (ou deixa de se referir) é um dos maiores pontos de discordância entre os analistas do autor checo. A questão pode ser - e talvez a estratégia de Kafka em seus textos tenha sido exatamente essa - a de que nunca saibamos se o que está escrito é alegórico ou não. Esta impossibilidade de determinar o sentido alegórico de um texto, ou o questionamento da necessidade de se expressar por alegorias, é abordada pelo próprio autor em um pequeno conto:

Muitos se queixam de que as palavras dos sábios sejam sempre alegorias, porém inaplicáveis na vida diária, e isto é o único que possuímos. Quando o sábio diz: "Anda para ali", não quer dizer que alguém deva passar para o outro lado, o que sempre seria possível se a meta do caminho assim o justificasse, porém que se refere a um local legendário, algo que nos é desconhecido, que tampouco pode ser precisado por ele com maior exatidão e que, portanto, de nada pode servir-nos aqui.

Em realidade, todas essas alegorias apenas querem significar que o inexequível é inexequível, o que já sabíamos. Mas aquilo em que cotidianamente gastamos as nossas energias, são outras coisas.

A este propósito disse alguém: "Por que vos defendeis? Se obedecêsseis às alegorias, vós mesmos vos teríeis convertido em tais, com o que vos teríeis libertado da fadiga diária."

Outro disse: "Aposto que isso é também uma alegoria."

Disse o primeiro: "Ganhaste".

Disse o segundo: "Mas por infelicidade, apenas naquilo sobre alegoria".

O primeiro disse: "Em verdade, não; no que disseste da alegoria perdeste." ${ }^{62}$

${ }^{62}$ Das Alegorias, in: O abutre e outras histórias, 2009, p. 15. Sobre qual parte do que foi dito sobre alegoria a segunda pessoa "perdeu"? Se formos tomar a primeira parte do conto como uma alegoria, assim como o interlocutor, a crítica direciona-se exatamente a que? Em uma primeira leitura, Kafka poderia se referir às alegorias religiosas, por exemplo: segui-las fielmente transformar-nos-ia em alegorias em si, em caricaturas. Porém, isso seria extensível a toda alegoria à qual devêssemos "obedecer" (ideologias, política, costumes sociais, etc.) e nos libertaria da "fadiga" do questionamento. Se, ao contrário, a primeira parte do conto deva ser lida literalmente, o que é criticado é a própria função ou necessidade de alegorização do real. 
A problemática símbolo-alegoria oculta, também, uma dimensão ideológica ${ }^{63}$. A obra de Kafka é vista por muitos de seus analistas como uma alegoria da desesperança e da alienação do ser humano, ao ponto de considerá-las inerentes (ou imanentes) à condição humana. Mas Kafka fecharia a saída para a superação da alienação ao colocá-la neste patamar? Dialeticamente falando, se a alienação e a desesperança (ou angústia) são imanentes ao ser, não estão em contradição com sua natureza, logo não poderiam ser sobrepujadas. Para Lukács, a arte moderna (alegórica) reduz o ser à impotência e esvazia qualquer possibilidade de ação, e o autor checo seria a epítome desta paralisia:

Essa impressão de impotência elevada ao nível de concepção do mundo, que em Kafka se transformou na angústia imanente do próprio devir do mundo, o total abandono do homem em face dum temor inexplicável, impenetrável, inelutável, faz da sua obra como que o símbolo de toda a arte moderna. Todas as tendências que, noutros artistas, assumiam uma forma literária ou filosófica, reúnem-se aqui no temor pânico, elementar, platônico, perante a realidade efetiva, eternamente estranha e hostil ao homem, e isto num grau de espanto, de confusão, de estupor, que não tem paralelo em toda a história da literatura. A experiência

${ }^{63}$ Este é um dos centros da análise de LUKÁCS (1969, passim). Para ele, as inovações estético-formais da obra de Kafka, ainda que admiráveis, não são suficientes como tentativa de superação das contradições da realidade e do capitalismo. Lukács vê o romance realista como uma forma mais adequada de apreensão da individualidade e das condições gerais da sociedade, por sua característica de composição de tipos (personagens que vivem em um determinado pano de fundo e atravessam situações típicas). Tais situações permitiriam, sua visão, uma perspectiva mais aguda tanto do caso particular (definidor do romance como forma literária) como do quadro geral da sociedade onde tal caso ocorre, permitindo entender de forma mais aprofundada a mentalidade da época na qual tal romance foi escrito. Da mesma forma, visto que o romance é a forma literária burguesa por excelência, o romance burguês realista permite o deslindar das contradições e ideologias que dão suporte a este tipo de sociedade. Para que isto ocorra, é necessária a coincidência entre o sensível e o não-sensível, ou seja, o simbólico. As minúcias descritivas de Kafka, apesar de o aproximarem de tal realismo necessário, não seriam suficientes, para Lukács, pois as ações deveriam estar em primeiro plano, e não os detalhes. Assim como Brecht apontará a respeito da falta de lições explícitas nas parábolas kafkianas, Lukács não considera que a aproximação alegórica com o real seja suficiente para provocar a reflexão crítica do leitor, talvez por não permitir, aparentemente, uma solução dialética para a questão homemmundo. 
fundamental da angústia, tal como a viveu Kafka, resume bem a decadência moderna da arte ${ }^{64}$.

A alegoria em Kafka seria vazia de significado político? 0 rompimento da coerência do mundo experimentado na obra kafkiana ocorre "a fim de nele fazer reinar uma vida que ignora qualquer consolação, que torna insensíveis todos os projetos humanos ${ }^{65 "}$ ? Seria Kafka um conformista? A questão política na obra kafkiana será tratada posteriormente, mas não se pode descartar tão rapidamente a alegoria sem a pensarmos como uma "representação (ou figuração mimética) da essência de uma realidade social e humana historicamente determinada66". Uma alegação do real. Os sentimentos-chave de perda e isolamento presentes na obra de Kafka também são aqueles que servem de base para a criação de governos e religiões, entre outras estruturas presentes no real.

Ler os textos como se fossem apenas alegorias, no sentido raso do termo, faz com que busquemos "preenchê-las", atribuindo sentidos prévios a elas e esvaziando a própria alegoria de sentido. 0 estranhamento causado ao lermos as alegorias de Kafka de forma literal, ou seja, como se o que está descrito correspondesse plenamente à realidade, é o que daria ao leitor a possibilidade de compreender o "enigma", ou seja, delimitar o objeto que está sendo alegorizado: "o fantástico está a serviço do realismo ${ }^{67 " .}$

\footnotetext{
${ }^{64}$ LUKÁCS, 1969, p. 61

65 ibid., p. 72

${ }^{66}$ COUTINHO, 2005, p.1. O pensador brasileiro opera uma interessante inversão sobre o pensamento lukacsiano. Se para Lukács a vanguarda na qual Kafka se inscreveria padece de uma crônica falta de correspondência com o real, reduzindo o mundo a uma simples particularidade, Coutinho observa que o pressuposto à obra kafkiana (o conteúdo sóciohistórico) é reposto por meio da estrutura dos textos, denominando este processo de "poética do realismo". Tal pensamento se aproxima do conceito adorniano de imbricação entre arte e sociedade e traz à discussão a possibilidade de uma representação alegórica do real ainda assim ser realista. Para Coutinho, toda a arte contemporânea pode ser pensada dentro deste prisma representativo/mimético, no que é acompanhando, com certas ressalvas, por Lowy.

${ }^{67}$ LOWY, in COUTINHO, 2005, p. 6
} 
É desta oposição de elementos, aparentemente contraditória, que a força da obra de Kafka surge, tendendo não para uma conciliação, mas para o desvelamento de possibilidades no aqui e agora, invertendo a dialética nos moldes hegelianos. Ao criar tal espaço de estranhamento, as alegorias de Kafka ultrapassam a simples relação leitor-obra e passam a operar no real, como resistência.

Desta forma, o objeto da obra kafkiana é, para Adorno, maior do que o homem imóvel perante um mundo de difícil compreensão. Não há conformismo ou desesperança em Kafka; há uma necessidade imensa não em ser compreendido, mas em levar o leitor a este desafio, a despertar e constatar a existência de um ponto de fuga - ou construir um. Em vez do pessimismo, a obra de Kafka guarda uma aposta na vida: "nada disso atravessando as palavras há restos de luz"68.

Isso daria um novo sentido à afirmação adorniana de que não devemos "confundir a tese abstrata da obra kafkiana, a obscuridade da existência, com o conteúdo de sua obra" ${ }^{\prime 69}$. De certa forma, a existência desta saída desmente as interpretações tradicionais sobre Kafka ${ }^{70}$, carregadas de fatalismo perante um mundo monolítico e no qual restaria ao homem "cumprir humildemente e sem muita esperança seus deveres imediatos, integrando-se a uma comunidade que espera exatamente isso $^{71 "}$. Podemos tomar o trecho abaixo de Adorno, em Tempo Livre, como exemplo desta nova possibilidade de leitura:

Os interesses reais do indivíduo ainda são suficientemente fortes para, dentro de certos limites, resistir à apreensão total. Isso coincidiria com o prognóstico social segundo o qual uma sociedade cujas contradições fundamentais permanecem inalteradas também não poderia ser totalmente integrada pela consciência ${ }^{72}$

\footnotetext{
${ }^{68}$ KAFKA, in BARRENTO (2006, p.104).

${ }^{69}$ AsK, p. 240

${ }^{70}$ E também sobre Adorno, visto também injustamente como "pessimista" e "apocalíptico" (Cf.BOLLE, in TIBURI, 1995, p.136)

${ }^{71}$ AsK, loc.cit.

${ }^{72}$ ADORNO, 2004, p. 116
} 
Comparativamente, em Kafka temos a insubmissão de Amália ${ }^{73}$ como um manifesto desta resistência - ou sobrevivência da capacidade de resistir à injustiça do sistema. Lembremos, também, que no fundo, $O$ Processo versa sobre um inocente que é acusado por uma máquina burocrática hipócrita e confusa - e também sobre a diferença entre legalidade e justiça. Tal denúncia é em si resistência por sua "capacidade de resistir a uma situação extrema, transformando-a em linguagem"74 e pela habilidade de "produzir arte a partir do que é recusado pela realidade ${ }^{\prime 75}$, constituindo-se como ruptura em relação ao tecido social, desafiando o leitor.

Todavia, também é possível buscar estes novos significados por meio de um ajuste extremo e quase caricato a este tecido social, uma superconformidade $^{76}$ que estica os limites formais até o ponto de esgarçamento. Adorno aponta tal possibilidade no texto kafkiano: "Na obra de Kafka, tudo é o mais duro, definido e delimitado possível" ${ }^{\prime 77}$. A burocracia retratada por Kafka, assim como seu uso de um idioma alemão visto como "protocolar", a "linguagem dos escritórios", podem ser

${ }^{73} \mathrm{Em}$ O Castelo. Ao se negar a satisfazer as vontades de um dos funcionários do castelo, Amália atrai as maiores desgraças à sua família, mas resiste sem ceder em nenhum instante (Cf. LOWY, 2005, p. 185). O mesmo comentador observa o papel da alegoria como desvelamento da realidade no texto kafkiano: "Trata-se da criação de um universo imaginário, regrado unicamente pela lógica do maravilhoso que, de modo algum visa reproduzir ou representar a realidade, mas que não deixa de conter uma crítica radical dela, feroz ou irônica segundo o caso. Realista ou não, a obra de Kafka, graças à sua atitude de distanciamento permanente com relação às instituições sociais, é um dos exemplos mais cativantes do poder de iluminação profana da literatura. É por isso que André Breton o considerava, pura e simplesmente, o maior vidente do século".

${ }^{74}$ AsK. p. 250

${ }^{75}$ Ibid., p. 247

${ }^{76}$ KRIPS (2007, passim) apresenta uma interessante tese sobre o extremo rigor formal de um dos ensaios mais famosos de Adorno narrado pelo próprio autor em transmissões radiofônicas: "Educação após Auschwitz" segue um rigor acadêmico tão extremado exatamente para provocar nas pessoas a estranheza por este tipo de linguagem estar presente em um meio de massa. Ou seja, o rigor extremo da forma-ensaio, visto como conservador, é o que destoa e revoluciona na paisagem massificada. A apropriação do alemão protocolar, "idioma" pobre de significado, para a transmissão de novos sentidos obriga o uso de um léxico restrito de forma inovadora, ou conforme Deleuze, para "estranhos usos menores" (K. p.26).

${ }^{77}$ AsK, p. 240 
entendidas como uma subversão, uma exploração de limites que ressignifica a relação entre a língua e o tecido da sociedade. Este caráter protocolar da língua pode ser comparado à visão deleuziana sobre a ausência de alegorias na escrita kafkiana ${ }^{78}$.

Ao utilizar a língua alemã falada em Praga, que não pertence totalmente nem ao território do alemão erudito nem ao iídiche falado nas comunidades judaicas, Kafka busca um modo de composição e prática da linguagem que produza novos sentidos a partir de velhas e poucas palavras, usando para isso a sobriedade e economia na escrita. Em seu comentário sobre o iídiche, Kafka caracteriza a língua menor a partir de sua capacidade de constituir novas relações de representação por meio da reapropriação e mudanças de sentido do vocabulário utilizado:

O iídiche consiste apenas de palavras estrangeiras. Mas estas não estão firmemente enraizadas nele, elas retêm a velocidade e vivacidade que as fizeram ser adotadas. Grandes imigrações se movem por meio do iídiche, de um extremo a outro. Todo este alemão, hebraico, francês, inglês, eslavo, holandês, romeno, e até latim, é capturado e

\footnotetext{
${ }^{78}$ Adorno, acompanhando o pensamento de Benjamin, vê em Kafka um mestre da alegoria, tipo de construção que exige profundo domínio linguístico: "a prosa de Kafka se alinha com os proscritos também por buscar antes a alegoria do que o símbolo. Benjamin a definiu com razão como parábola" (AsK, pp. 240-241). Já Deleuze vê a literatura "menor" kafkiana despida destes atributos alegóricos devido à sua economia de vocabulário e seu caráter literal, cirúrgico. Mas a divergência camufla uma micro-dialética que operaria entre a abordagem dos autores citados sobre a alegoria: fazer o alemão vibrar de novas formas, dentro de um vocabulário limitado, possui certa semelhança com o conceito que Benjamin e Adorno atribuem à alegoria. Ao menos, do ponto de vista prático, aquela gramática magra deve ser dominada com precisão para adquirir a expressividade ou os significados desejados. Se adotarmos o conceito de desterritorialização como uma reapropriação para novas finalidades, pode-se dizer que Kafka sequestra o idioma alemão para reposicionar seus significados: a palavra passa a ser uma alegoria ao mesmo tempo que tem sua literalidade exacerbada. Com um vocabulário restrito (o alemão "protocolar") e utilizado de forma literal ("O princípio da literalidade, certamente uma lembrança da exegese da torá feita pela tradição judaica, pode se apoiar em vários textos de Kafka." AsK, p. 242), Kafka descreve imagens poderosas: "às vezes as próprias palavras, principalmente as metáforas, se libertam e ganham uma existência própria" (AsK, p. 242). Um exemplo são as figuras animais kafkianas, portadores do resíduo/resistência que caracteriza a arte tanto em Adorno como em Deleuze: ao provocarem o estranhamento, abrem novas possibilidades de visão. Se a forma ocupa lugar de destaque na abordagem que Kafka faz do ato de escrever, a escolha cirúrgica das palavras possui função na construção e entendimento do texto, pois elas remetem a outros significados. Os "protocolos" kafkianos, caracterizados pela economia de vocabulário, tornam-se assim um tipo singular de alegoria, no qual a literalidade no léxico e na significação opera um papel importante.
} 
incluído com curiosidade e frivolidade assim que contaminado pelo iídiche, e exige um grande esforço manter todas estas linguagens juntas, neste estado ${ }^{79}$.

Se no í́diche a riqueza do léxico surge desta apropriação de palavras, o alemão de Praga é uma língua "pobre", visto que aqueles que a usam não a dominam plenamente. O vasto léxico alemão é simplificado para a linguagem do cotidiano, da burocracia - ambiente de trabalho de Kafka: é uma "linguagem de papel ${ }^{80 "}$ ou artificial que ele usa para reatar relações com o real. Mas tal magreza de vocabulário não é, em seu limite, um impeditivo para a compreensão da escrita e, certamente, exige o extremo domínio de seus processos e modos de composição para a criação da obra, pois o autor checo busca que este vocabulário econômico assuma uma nova cor. A sobriedade exige tanto ou mais do que o excesso ${ }^{81}$. Neste ponto, a prosa de Kafka se aproximaria da poesia de

\footnotetext{
${ }^{79}$ KAFKA, 1983, p. 69.

${ }^{80}$ K., p. 26. Deleuze e Guattari veem em Kafka um tipo de criação que não está contida nas leituras tradicionais do autor (seja pelo viés psicológico, biográfico ou místico) e que opera como uma máquina de escritura/expressão: "Kafka mata deliberadamente toda a metáfora, todo simbolismo, toda a significação, assim como toda a designação" (K., p.40). Deleuze entende a metáfora como um tipo de envelope ou camisa de força para o conceito. Por isso, considera que não se trata de buscar interpretações e significados para aquilo que Kafka diz, e sim entender seu funcionamento - o como é dito - não se atendo aos efeitos individuais da leitura da obra. A obra em si opera como um laboratório de experimentação onde as experiências ocorrem na forma, no discurso e na linguagem utilizada. É possível imaginarmos um paralelo entre esta abordagem e o conceito de "fábula sem moral": como a lição não está dada, estamos livres para capturar seu significado. Conforme CARONE (2009), "Kafka sustenta com todas as letras que o conteúdo e a forma da frase devem coincidir de maneira precisa. Sua fé flaubertiana na linguagem usada com discernimento e responsabilidade o faz afirmar que "o sentimento infinito permanece tão infinito nas palavras como era no coração" (p.80). Para Kafka a palavra justa tem vida própria, que requer a maior vigilância, e o empenho para captá-la, ou capturá-la, é descrito com o humor e a agilidade típicos de quem conhece por dentro aquilo de que está falando: "Meu corpo inteiro me adverte diante de cada palavra; cada palavra, antes de se deixar escrever por mim, olha primeiro para todos os lados". (CARONE, 2009, p. 80-81)

${ }^{81}$ É possível aproximar as qualidades da forma-conteúdo da obra de acordo com Adorno e a visão deleuziana sobre o escrever em Kafka, que pode ser visto como uma forma de rearticulação das relações entre escritor e vida: a literatura não é mais constituída a partir de imagens ou reconstruções imaginárias do mundo, e sim a partir da experiência do mundo, dando sentido a este. Uma tese a ser averiguada aqui é a de que o que regeria a questão da escrita em Kafka é mais a forma (sua desorganização e reorganização como máquina, para Deleuze, ou a impossibilidade de separação entre forma e conteúdo, para Adorno) do que o conteúdo tomado isoladamente. Para Deleuze, a obra de Kafka é desejo de escrever,
} 
Samuel Beckett, também visto por Deleuze como um autor de literatura menor com a mesma característica "de sobriedade, de pobreza voluntária, levando a desterritorialização até ao lugar onde apenas subsistem intensidades". ${ }^{82}$

Ainda em Deleuze, a não-existência da "massa" que compartilha uma identidade faz com que as pessoas e minorias nunca estejam à vontade dentro deste grupo maior. Elas vivem imersas em uma linguagem que não Ihes pertence. A prosa de Kafka, como epítome deste tipo de literatura, refletiria a dificuldade dos judeus de Praga em expressarem sua consciência de si pela literatura, pois só poderiam escrever num idioma que não thes pertence, do qual não possuiriam o domínio pleno e que simboliza a "distância irredutível em relação a uma territorialidade primitiva, a checa ${ }^{83 "}$.

Sendo a desterritorialização tanto a liberação da força de trabalho de meios específicos de produção como a reconfiguração dos laços entre a cultura e seu lugar no espaço e no tempo, o fato de Kafka ser um judeu de Praga escrevendo em alemão mostra tanto a dificuldade citada como a necessidade imperiosa de expressão deste grupo. Não havia outra possibilidade de expressão e escrita, portanto era necessário fazer algo a respeito: utilizar de formas novas a linguagem maior, libertando novos significados a partir dos meios - palavras - específicos ${ }^{84}$.

ler e amar, não a interiorização de si ou ausência da lei. O comentário de Carone sobre o método da escrita kafkiana sustenta, de certa forma, esta ideia: "Com certeza era por isso que Kafka dizia ser necessário escrever na obscuridade, como se fosse num túnel: "minhas histórias são uma espécie de fechar de olhos", diz ele. O que, por sinal, não o impede de conceber seu trabalho como um esforço para encontrar, flaubertianamente, a palavra justa, pois para ele a escrita essencial é uma forma de oração ou, por outra via, um "assalto à fronteira". (itálico nosso) (CARONE, 2009, p. 62)

${ }^{82}$ K., p. 35. Outro autor considerado de literatura menor por Deleuze e Guattari é James Joyce, mas este se utilizaria de um processo oposto: a exuberância e proficuidade de seus neologismos operam "todas as reterritorializações mundiais" (K., p. 35)

${ }^{83}$ K., p. 26

${ }^{84}$ Citando Deleuze, "vale dizer que o 'menor' não qualifica mais certas literaturas, mas as condições revolucionárias de toda literatura no seio daquela que chamamos de grande (ou estabelecida). Mesmo aquele que tem a infelicidade de nascer no país de uma grande literatura, deve escrever em sua língua, como um judeu tcheco que escreve em alemão, ou como um usbesque que escreve em russo. Escrever como um cão que faz seu buraco, como um rato que faz a sua toca. E, para isso, encontrar o seu próprio ponto de 
Isso só é possível graças à capacidade do autor checo em retratar seu tempo sem ser aprisionado por ele. O vigor da obra permanece porque, de alguma forma, nela aparece algo que nos remete ao que não foi superado em seu tempo - e que ainda ecoa ou existe no nosso, seja este algo de ordem política, sentimental ou metafísica. Ou, citando Adorno, "os antagonismos não resolvidos da realidade retornam à obra de arte como os problemas imanentes da sua forma" ${ }^{85}$.

No caso, a sobriedade e crueza do texto modificam a relação entre texto e leitor, substituindo a fruição como contemplação pela fruição como urgência, levando o leitor a uma espécie de vertigem que está imbricada na própria obra ${ }^{86}$.

Kafka impõe ao observador de outro tempo, supostamente desinteressado, um esforço desesperado, que lhe assalta e sugere que de sua correta compreensão depende muito mais do que seu equilíbrio espiritual: é uma questão de vida ou morte. $^{87}$

A discussão sobre a pertinência da noção de parábola em Kafka ${ }^{88}$ segue um caminho similar: uma interpretação bastante aceita considera que o escritor checo subverte esta forma narrativa, tradicionalmente associada à transmissão de um ensinamento moral a ser aplicado na vida prática e à consolidação da autoridade cristalizada nesse ensinamento.

A parábola de Kafka se constituía, contudo, como o paradoxo de uma parábola sem doutrina, o que era explicado por Benjamin pelo fato de ela figurar o desmoronamento da doutrina judaica que conferia sentido à interpretação do ensinamento contido nos textos sagrados.

subdesenvolvimento, seu próprio patoá, seu próprio terceiro mundo, seu próprio deserto". K., p.28

${ }^{85}$ TE, p. 16

${ }^{86}$ A sensação de vertigem, ou o choque disruptivo entre imagem e pensamento, aponta uma ligação com a problemática do sublime a partir da assincronia entre signo, significado e significante no uso da linguagem.

${ }^{87}$ AsK. p. 241

${ }^{88}$ Cf. GATTI, 2009, p. 141 et seq. A diferença entre Benjamin e Brecht sobre o conceito da parábola serve como exemplo claro desta discussão teórica. 
Na ausência dessa chave de leitura que vinculava os textos à verdade fundada na doutrina, Kafka transformara a parábola em um enigma indecifrável. ${ }^{89}$.

A ausência do ensinamento, porém, era vista por outros como uma falha na obra kafkiana. Por exemplo, para Brecht o que Kafka escreve é tomado por uma "estéril profundidade ${ }^{90 ", ~ v i s t o ~ q u e ~ e s t e ~ s e ~ r e c u s a ~ a ~}$ embutir no texto um código de conduta ou uma pedagogia para as massas. A parábola de Kafka, para o dramaturgo, nunca foi "inteiramente transparente ${ }^{91 \prime \prime}$.

A posição brechtiana talvez não leve em conta a possibilidade de Kafka extrair destes esquemas narrativos apenas o necessário para a construção de sua história, sem a necessidade de se prender a um deles de forma plena. Da fábula, temos o caráter fantástico - com a ressalva da inversão da narrativa animal. Da parábola, o uso de uma linguagem simbólica; e do apólogo o não-enquadramento da lição de moral, visto que esta figura de linguagem não tem como tema, necessariamente, uma lição de vida que possa ser adotada pela maioria como forma de ação no cotidiano ${ }^{92}$.

\footnotetext{
${ }^{89}$ Ibidem

${ }^{90}$ Ibidem. Neste ponto, as análises de Brecht e Lukács se aproximam.

${ }^{91}$ Cf. GATTI, op. cit, p. 141 et seq

${ }^{92}$ Ao se compararem as narrativas da fábula, da parábola e do apólogo, é possível observar que os apólogos têm o objetivo de atingir os conceitos humanos de forma que os modifique e reforme, levando-os a agir de maneira diferente. Os exemplos são utilizados para ajudar a modificar conceitos e comportamentos humanos, de ordem moral e social. Diferencia-se da fábula por se concentrar mais em situações reais, enquanto a fábula dá preferência a situações fantásticas e também pelo fato de a fábula se utilizar de animais como personagens. Diferencia-se da parábola pois esta trata de questões religiosas e lições éticas, enquanto o apólogo fala de qualquer tipo de lição de vida, mesmo que esta não seja a que é adotada pela maioria como a maneira correta de agir. Na Estética de Hegel, o apólogo surge como "uma parábola que não usa apenas por similitude o caso singular para tornar intuitivo um significado universal, mas apresenta e exprime neste revestimento a sentença universal, na medida em que a mesma está contida efetivamente no caso singular, que todavia é contado apenas como um exemplo singular" (HEGEL, 2001, p. 119-120). As obras de Kafka parecem acolher essa característica de desvelamento do geral naquilo que é visto apenas como ilustrativo. Conforme PEREIRA, "no apólogo, a fábula é independente da sua interpretação moral. Funciona como um acumulador de sentidos e faz-se eco de focalizações de afectos, reminiscências de histórias originais. A moral insere-a numa determinada cultura, isto é, num determinado espaço e num determinado tempo, por vezes de forma tão tênue ou tão forçada ou tão inábil que o processo
} 
O próprio autor, pelo que se sabe, era avesso à compreensão de sua obra dentro dessa forma estilística. Ao contrário, parecia especialmente incomodado com tal associação, ao ponto de recomendar expressamente a seu editor, Kurt Wolff, providências para evitar tal identificação. Conforme Carone,

Embora Wolff tenha achado as histórias de Um Médico Rural 'excepcionalmente belas e maduras' e quisesse investir no aproveitamento editorial delas, Kafka não permitiu que ele as tomasse por parábolas e alegorias ${ }^{93}$.

Assim, pode-se sugerir uma apropriação intencional da forma da parábola e da alegoria, mas sem uma obediência canônica às suas dinâmicas internas ${ }^{94}$, o que remete à relação entre os problemas da forma e os problemas de uma sociedade ${ }^{95}$.

A dialética operada aqui expõe os paradoxos da racionalidade em contato com os acontecimentos do século $X X$, um tempo no qual o racional e a barbárie convivem de forma doentia. Para Adorno, a obra de Kafka é um exemplo da exploração destes paradoxos e ao mesmo tempo a obra forma um campo no qual as regras da razão instrumental não operam plenamente.

Esta leitura de Kafka busca, segundo alguns críticos, revelar o mundo real que está presente no interior de suas obras "surreais". Tal revelação opera simultaneamente como denúncia e resistência, visando

\footnotetext{
parece querer desmascarar-se voluntariamente." (PEREIRA, 2007, p. 27). Logo, o apólogo pode ser entendido como uma fábula sem moral.

${ }^{93}$ CARONE in UMR, p. 76-77

${ }^{94}$ Tal possibilidade acaba por nos aproximar novamente da ideia de Deleuze e Guattari de que a questão mais importante na obra de Kafka não é o que é dito, e sim como é dito. A obra passa a ser vista como máquina de expressão e o autor "mata deliberadamente" a metáfora, o simbólico, como forma de apreensão do significado do texto. Conforme ROSENTHAL, "as obras de Kafka são, de um modo geral, parábolas sem conclusão. Oferecem ao leitor processos, manifestações e feitos modelares que, sem expressá-lo nitidamente, marcam posições fundamentais de gênero humano, sendo que assim provocam a perplexidade de uns e a curiosidade de outros, vindo a exercer profunda influência." (THEODOR ROSENTHAL, 1968, p. 156)

${ }^{95}$ Cf. a teoria estética de Adorno.
} 
encontrar uma saída dentro do próprio problema que parece sem saídas: a regressão da razão à barbárie e a formatação do pensamento. $E$, com isso, localizar o último bastião de resistência dentro do indivíduo, exatamente como o projeto filosófico adorniano da superação da lógica identitária: "Com a força do sujeito, quebrar a ilusão (Trug) da subjetividade constitutiva."

Kafka é entendido como a tradução do mundo que o cerca: uma sociedade em mutação permeia e atravessa a obra - na qual traços arcaicos convivem com a gênese do "contemporâneo" - como evidenciam suas figuras animais nas quais o indivíduo se encontra como que imobilizado entre a expressão da racionalidade que a sociedade exige e as demandas de sua individualidade. "O permanente déjà-vu é o déjà-vu de todos $^{97 \prime \prime}$.

Mas isto não ocorre de forma a reduzi-la a um retrato de seu tempo ou das angústias de um momento histórico específico, o que seria retirar também a sua força: ela atinge uma universalidade exatamente porque as assincronias que the dão a força da expressão não se encontram resolvidas. Adorno comenta que os cenários de Kafka são "sempre obsoletos $^{98 ",}$ e usa como exemplo o prédio que funcionava como escola em 0 Castelo, do qual "é dito que reunia de modo estranho o caráter do provisório com o do muito antigo' ${ }^{99 " .}$. O prédio significa a reelaboração do arcaico, fugidia, já a priori obsoleta; sua simples lembrança ou resgate $e^{100}$ não dá conta de explicar o que ocorre. O arcaico deve ser pensado de

\footnotetext{
${ }^{96}$ ADORNO, 1975, p. 10

${ }^{97}$ AsK, p. 248

98 Ibid., p. 254

99 ibidem
}

100 O provisório apontado por Adorno nesta passagem de Kafka nos indica o presente, aquilo que não está, digamos assim, "fixado". Se o provisório se torna permanente, torna-se passado. Percebe-se aqui certa reverberação da análise de Benjamin, mas com uma diferença de abordagem substancial: se em Adorno "o passado (sob a forma de elementos arcaicos) importa na medida em que condena e denuncia as práticas do presente" (SANTOS, 2008, p. 150), Benjamin busca as formas pelas quais o passado se mostra ainda operante no presente, sendo o presente o meio pelo qual ele observa como a tradição se transmite e se sustenta - ou não. 
acordo com seu entrelaçamento com o presente, permanentemente em construção.

Ou seja, para Adorno, "enquanto a palavra do enigma não for encontrada, o leitor permanece preso ${ }^{101 "}$. Enquanto não se decifrar o funcionamento do tecido que gera e é gerado por estas contradições, não há como entendê-las ou superá-las. A busca desta decifração das condições do mundo exige um duplo olhar sobre o objeto da análise, "o déjà-vu em permanência ${ }^{102 ": ~ h a ́ ~ a l g o ~ d e ~ e s t r a n h a m e n t e ~ f a m i l i a r ~ e ~}$ inquietante - (un)heimlich - no modo como Kafka o descreve. E talvez sua escrita tenha o poder de provocar em nós a surpresa de descobrir algo que nunca havíamos visto, mas que, no fundo, já suspeitávamos que estivesse lá. Ao provocar nossa razão, Kafka obriga-nos a utilizá-la de forma crítica, apontando e mapeando as contradições do sistema.

Essa é a ferramenta de resistência em relação ao mundo homogêneo que nos cerca. "Só o trabalho do pensamento, consciente de si mesmo, consegue escapar a esse poder alucinatório e, segundo o idealismo de Leibniz e de Hegel, a filosofia"103. Ter a consciência de si é a difícil tarefa em um mundo no qual a própria noção do Eu já está predeterminada, de acordo com o filósofo alemão, pelas assim chamadas "ferramentas" que condicionam o processo de formação de consciências. Por este prisma, pensar - criticamente - é resistir a esse semipensamento formatado, é deslocar seu ponto de visão e ver o mundo com outros olhos.

Seja fábula, alegoria, símbolo, parábola ou apólogo sem moral, o caráter de denúncia e de estranhamento perante um mundo em mudança - no qual há uma profunda suspeição em relação a esta moral dita positiva e que é evidente nas formas clássicas dessas narrativas - é um elemento importante para o entendimento do autor checo.

\footnotetext{
${ }^{101}$ Ibid., p. 241

102 ibidem.

${ }^{103}$ DE, p. 181
} 


\section{O MIMÉTICO}

De que forma a narrativa de Kafka operaria uma representação mimética da realidade? Torna-se necessária uma análise dos elementos textuais no autor checo para esboçarmos uma resposta a tal questão.

A imitação das ações do homem e da natureza, para Aristóteles, é a essência da arte, pois ela não se restringe a um retratar. Ao contrário, significa um fazer, uma práxis, um processo. Uma expressão consciente, que não necessariamente precisa estar vinculada a uma linguagem falada.

Se para buscar a compreensão sobre Kafka é necessária a compreensão de seu método de composição narrativa, não é menos importante o mapeamento de que elementos desta concorrem para que seja possível estabelecer uma relação entre o processo mimético e a obra do autor checo.

\subsection{Gesto}

Uma característica do texto de Kafka é a profusão de descrições de gestos e ações corporais. Mais que como uma simples ênfase de um diálogo, ele opera como elemento expressivo e significante na narrativa. Em conflito direto com a leitura de Walter Benjamin, que influenciado por Brecht analisou o gestual em Kafka em comparação ao teatro chinês ${ }^{104}$, Adorno fixa-se na relação entre linguagem e gesto, considerando este como um "contraponto para a palavra", uma forma de expressão antiga, a qual supera o bloqueio de comunicação resultante da derrocada da linguagem.

\footnotetext{
${ }^{104}$ A extensa disputa intelectual entre Adorno e Brecht exigiria um texto exclusivo para ser devidamente analisada. Por enquanto, é importante citarmos a disputa de ambos por influência sobre o pensamento de Benjamin.
} 
O gesto comunica tanto ou mais que a verbalização do conceito, por remeter diretamente - sem mediações ou conceitos prontos - ao fato ou ao que precisa ser comunicado. Observa-se assim no texto kafkiano uma outra maneira de torcer a relação entre o emissor e o receptor da informação (além do deslocamento na dinâmica entre narrador e leitor $\left.^{105}\right)$.

Tais gestos são os vestígios de experiências que foram encobertas pelos significados. É o mais novo estado de uma língua que enche a boca dos que a falam, é a segunda confusão babilônica, à qual a dicção sóbria de Kafka resiste, forçando a inverter a relação histórica entre conceito e gesto, como num espelho. O gesto é o "assim é". ${ }^{106}$

Tal inversão é visível em um trecho como este, de $O$ Castelo, que precede a demissão do pai de Olga da brigada de fogo. O chefe

\begin{abstract}
Seemann não pode falar nada. Dá tapinhas sem parar nos ombros do pai, como se desejasse que este fizesse saírem as palavras que ele próprio deve dizer e não encontra. Nesse meio tempo ri sem cessar, gesto com o qual quer com certeza acalmar um pouco a si mesmo e aos outros; mas uma vez que não sabe rir e nunca ninguém ainda o ouviu rir, não ocorre a nenhuma pessoa acreditar que se trata de um riso. Mas o pai já está desesperado e cansado desse dia para poder auxiliar Seemann; parece mesmo cansado até para pensar no assunto de que se trata ${ }^{107}$. (grifos nossos)
\end{abstract}

Ruídos ininteligíveis e gestos substituindo palavras: o que não pode ser dito pode ser expressado de alguma forma, ainda que incompleta. 0 efeito do gesto sobre quem o contempla nos remete às imagens expressionistas tão caras ao escritor ${ }^{108}$, assim como às comédias mudas

\footnotetext{
${ }^{105}$ Conforme o tópico O Narrador

${ }^{106}$ AsK, p. 244

107 C., pp 203-204

${ }^{108}$ AsK, p. 258
} 
de Chaplin ${ }^{109}$ e Buster Keaton (nascidas da fusão entre o vaudeville e o teatro í́diche), nas quais gestos extremos - emoldurados por trilhas de piano - levam o espectador ao riso, ao choro ou ao terror ${ }^{110}$. O próprio Kafka diz: "uma vez que não sabe rir e nunca ninguém ainda o ouviu rir, não ocorre a nenhuma pessoa acreditar que se trata de um riso ${ }^{111 "}$. Cabe lembrar que no cinema mudo o ato precisa ser exagerado para ser reconhecido como tal.

$\mathrm{Na}$ correspondência entre Adorno e Benjamin a respeito do ensaio deste sobre Kafka, aquele faz uma interessante observação sobre esta ligação - não sem uma queixa a respeito da interpretação de Brod sobre as obras:

Assim, com sua referência banal ao filme, Brod parece haver acertado em algo muito mais preciso do que poderia suspeitar. Os romances de Kafka não são manuais de direção para o teatro experimental, pois Ihe falta, em princípio, uma plateia que pudesse participar do experimento. Eles são, antes, os últimos e evanescentes vínculos textuais com o cinema mudo (o qual, não por coincidência, desapareceu quase simultaneamente à morte de Kafka). A ambiguidade do gesto se dá entre o mergulho

\footnotetext{
${ }^{109}$ Nos arquivos de Walter Benjamin, abertos ao público em 2012, foi localizada uma nota que permite ver esta relação de forma mais clara: "Chaplin é chave para entender Kafka, na medida em que Chaplin oferece situações onde as condições do excluído e do deserdado, e a eterna dor humana se encontram ligados de maneira única às circunstâncias mais especiais da existência hoje em dia, o regime do dinheiro, a grande cidade, a polícia... em Kafka, todo acontecimento é, ao mesmo tempo, imemorável e uma notícia de última hora" (http://diversao.terra.com.br/arteecultura/noticias/0,,OI5432400-EI3615,00-

Arquivos+do+filosofo+Walter+Benjamin+sao+apresentados+em+Paris+pela+primeira+vez.ht $\mathrm{m})$

110 Principalmente nas películas de Wiene, Lang e Murnau. Alguns estudos indicam a existência de ecos do Nosferatu em textos de Kafka, principalmente em O Castelo e em trechos dos Diários e dos Oktavhefte, notadamente um trecho datado de 1922 (coincidentemente ano de produção de $O$ Castelo e de lançamento do filme citado) que reproduziria a chegada do viajante Thomas Hutter ao castelo do conde: "Já era tarde da noite quando eu toquei a campainha do portão. Demorou bastante até que o castelão saísse - indubitavelmente das profundezas do átrio - e o abrisse. "O senhor manda entrar", disse o criado fazendo uma reverência e abriu a alta porta de vidro com um solavanco sem ruídos. Da escrivaninha em que se encontrava ao lado da janela aberta e com um passo meio esvoaçante, o conde se apressou ao meu encontro. Observamos um ao outro nos olhos, o olhar fixo do conde me causou estranheza. (KAFKA, 2006, p. 608, in BENITEZ, 2010, p. 103)". Tal parentesco, se é que possa ser chamado assim, levanta outra possibilidade: a de que a figura do vampiro possa ser entendida como um novo tipo de devir-animal em Kafka.

${ }^{111}$ C., p.232
} 
no mutismo (com a destruição da linguagem) e a emersão dele na música - donde a peça mais importante na constelação gesto-animal-música provavelmente seja a descrição do grupo mudo de músicos caninos de Investigações de um Cão, que eu não hesitaria a equiparar a Sancho Pança. ${ }^{112}$

O gesto, ambíguo, remete a algo que se encontra encoberto pela linguagem. Benjamin e Adorno apontam na mesma direção por caminhos diferentes: a literalidade e a ironia kafkiana efetuam-se tanto pela palavra como pelo gesto. Por meio deste, Kafka produz literatura, que nos remete ao que é universal, e teatro, que nos leva ao concreto, ao acontecimento ${ }^{113}$.

Os gestos também são indicativos de um processo de humanização: gesticular é comunicação sem palavras que envolve compreensão mútua, e a reprodução do gesto uma tentativa de contato e de semelhança. O

\footnotetext{
${ }^{112}$ ADORNO; BENJAMIN, in ZISCHLER, 2005 ,p. 76

113 Para os estudiosos do teatro pós-dramático, o conceito de "Acontecimento" significa a particularidade do teatro ser uma arte que acontece na presença mútua de executores e espectadores. Na visão deleuziana, acontecimento é uma relação de forças concretizada em um momento presente: "Em todo acontecimento, há de fato o momento presente da efetuação, aquele em que o acontecimento se encarna em um estado de coisas, um indivíduo, uma pessoa, aquele que é designado quando se diz: pronto, chegou a hora; e o futuro e o passado do acontecimento só são julgados em função desse presente definitivo, do ponto de vista daquele que o encarna." (LS, p. 177). O acontecimento tem portanto um caráter simultâneo e diferenciado no tempo (variando de acordo com o ponto de observação) e na linguagem, pois é diferente da proposição que o nomeia e também dos estados de coisas aos quais estaria vinculado. Para Deleuze, "não se perguntará qual o sentido de um acontecimento: o acontecimento é o próprio sentido. O acontecimento pertence essencialmente à linguagem, mantém uma relação essencial com a linguagem; mas a linguagem é o que se diz das coisas." (LS, p. 34). Assim, o acontecimento é inseparavelmente o sentido das frases e o devir do mundo; é o que, do mundo, é possível captar via linguagem e isto permite que a própria linguagem funcione. Entendendo o gesto como uma forma de dizer/comunicar sem palavras, mesmo assim o gestual acaba por assumir um status léxico. A obra em si é o acontecimento, ou, para Deleuze, a arte é a contra-efetuação do acontecimento, uma nova significação, um rearranjo dos elementos deste acontecimento. Tal rearranjo nos permite traçar uma linha de força entre a visão das duplas Deleuze/Guattari e Adorno/Benjamin sobre a reapropriação e ressignificação efetuada por Kafka em relação ao gesto e à linguagem. Conforme SANTOS (2007, p.153), "um dos elementos que fazem de Kafka aquilo que ele significa no âmbito literário é o fato de ele expressar na literatura, e não no teatro, embora fazendo uso extensivo do gestual, sua práxis de questionamentos linguísticos. Em outras palavras: é uma herança do teatro, como o quer Benjamin, e também é uma reflexão (sobre a) da aporia linguística, como o quer, por sua vez, Adorno". (itálicos nossos)
} 
macaco de Um Relatório para uma Academia diz: "Era tão fácil imitar as pessoas! Nos primeiros dias eu já sabia cuspir ${ }^{114 " . ~ A ~ d e d i c a c ̧ a ̃ o ~ d o ~}$ protagonista em buscar a reprodução do gesto denota a busca da união com aquilo a que deseja pertencer.

Só agora começo o exercício prático. Já não estava esgotado demais pela aula teórica? Certamente: esgotado demais. Faz parte do meu destino. Apesar disso, estendo a mão o melhor que posso para pegar a garrafa que me é oferecida; desarrolho-a trêmulo; com este sucesso se apresentam aos poucos novas forças; ergo a garrafa - quase não há diferença do modelo original; levo-a aos lábios e - com asco, com asco, embora ela esteja vazia e apenas o cheiro a encha, atiro-a com asco ao chão. Para tristeza do meu professor, para tristeza maior de mim mesmo; nem com ele nem comigo mesmo eu me reconcilio por não ter esquecido após jogar fora a garrafa - de passar a mão com perfeição na minha barriga e de arreganhar os dentes num sorriso ${ }^{115}$.

E a repetição do gesto, ato mecânico e desumanizante, leva ao reconhecimento da humanidade do macaco pelos demais humanos, conforme se lê nesta passagem de Kafka:

De qualquer modo, que vitória foi tanto para ele como para mim quando então uma noite, diante de um círculo grande de espectadores - talvez fosse uma festa, tocava uma vitrola, um oficial passeava entre as pessoas -, quando nessa noite, sem ser observado, eu agarrei uma garrafa de aguardente deixada por distração diante da minha jaula, desarrolhei-a segundo as regras, sob a atenção crescente das pessoas, levei-a aos lábios e sem hesitar, sem contrair a boca, como um bebedor de cátedra, com os olhos virados, a goela transbordando, eu a esvaziei de fato e de verdade; joguei fora a garrafa não mais como um desesperado, mas como um artista; na realidade esqueci de passar a mão na barriga, mas em compensação - porque não podia fazer outra coisa, porque era impelido para isso, porque os meus sentidos rodavam - eu bradei sem mais "alô!", prorrompi num som humano, saltei com esse brado dentro da

\footnotetext{
${ }^{114}$ UMR, p. 67

115 UMR, pp 68-69. Todo o processo de humanização do macaco se dá pela reprodução dos gestos, o que coloca este também no terreno da mimesis, tópico a seguir.
} 
comunidade humana e senti, como um beijo em todo o meu corpo que pingava de suor, o eco - "Ouçam, ele fala!". ${ }^{116}$

O significado do gesto na atualidade - operando-se aqui uma articulação dialética cara a Adorno, entre o elemento arcaico residual e o tecido da modernidade - é o que deve ser buscado, entendendo que no processo a própria linguagem experimenta uma profunda modificação, pois de código consciente para expressar significados, passa a ocultá-los: "Às vezes as experiências sedimentadas nos gestos seguirão a interpretação que deveria reconhecer na sua mímesis um universal reprimido pela consciência humana"117.

\subsection{Mímesis}

Se o gesto, mesmo exagerado, remete a algo que está interditado à compreensão mas que é reconhecível para quem o faz e a quem o contempla, o conceito de mímesis ${ }^{118}$ como imitação - aplicado à obra kafkiana - implica em uma ruptura no uso comum da linguagem.

A mímesis para Benjamin é também um processo de reconhecimento do outro e do entorno. O agir no mundo se dá a partir deste reconhecimento; a mímesis é uma práxis na relação individual/social. GAGNEBIN observa que

\footnotetext{
${ }^{116}$ UMR, pp 69-70

${ }^{117}$ AsK, p. 244

${ }^{118}$ Como o termo mímesis é recorrente nas análises de Adorno e Benjamin sobre Kafka, é necessário que exploremos um pouco mais seu significado em ambos os pensadores. Para SCHLESENER (2009, p. 149), por exemplo, “(...) muito mais que simples imitação, a mímesis se apresenta como a ação humana capaz de conhecer produzindo semelhanças, ou seja, capaz de '“fazer-se parecido', 'trazer algo à representação', encenar e expressar-se pela arte, principalmente a dança, embora o termo não se restrinja a essa atividade". (...) Nos escritos de Walter Benjamin, o conceito de mímesis assume um significado central" continua SCHLESENER - "como uma capacidade humana que concretiza a nossa inserção no mundo por meio da percepção e da linguagem. A capacidade mimética se apresenta como o dom de reconhecer e de produzir semelhanças para compreender e ordenar o mundo, atribuindo-lhe um sentido: representação e expressão são indissociáveis nesse processo". (2009, p. 149).
} 
Como já ressaltava Aristóteles, a mímesis será ligada por definição ao jogo e ao aprendizado, ao conhecimento e ao prazer de conhecer. O homem é capaz de produzir semelhanças porque reage, segundo Benjamin, às semelhanças já existentes no mundo. De maneira paradoxal, essas semelhanças não permaneceram as mesmas no decorrer dos séculos. A originalidade da teoria benjaminiana está em supor uma história da capacidade mimética. Em outras palavras, as semelhanças não existem em si, imutáveis e eternas, mas são descobertas e inventariadas pelo conhecimento humano de maneira diferente, de acordo com as épocas ${ }^{119}$.

Adorno compartilha em termos esta leitura de Benjamin, mas considera que este reconhecimento do outro passa necessariamente pelo método dialético para que não se transforme em simples replicação de comportamentos, como são, por exemplo, os rituais nos quais os guerreiros pintam as figuras de animais em seu corpo para adquirir a força e velocidade destes. Ou seja, para que a mímesis não se resuma a simples imitação. A elaboração deste momento de mímesis pela razão se dá em direção ao trabalho: o comportamento imitado adquire um caráter social e funciona como sublimação da energia inicialmente direcionada ao Eros. Conforme Adorno,

Inicialmente, em sua fase mágica, a civilização havia substituído a adaptação orgânica ao outro, isto é, o comportamento propriamente mimético, pela manipulação organizada da mímesis e, por fim, na fase histórica, pela práxis racional, isto é, pelo trabalho. ${ }^{120}$

Para Adorno, a imediaticidade não existe, pois dialeticamente falando sempre há uma mediação, uma "imediaticidade mediata (vermittelte Unmittelbarkeit), que provém do profundo (e compreensível) desejo de poder chegar a um conhecimento total, definitivo, no qual o

${ }^{119}$ GAGNEBIN, 1993, p. 80

${ }^{120}$ DE, p. 168 
objeto seria realmente alcançado e no qual o sujeito poderia repousar feliz"121. Porém, Benjamin vê a mímesis por outro ângulo, não como reprodução/cópia, mas como semelhança: o movimento do pensar se dá não de forma linear, mas metafórica e contígua, ou "não num depois do

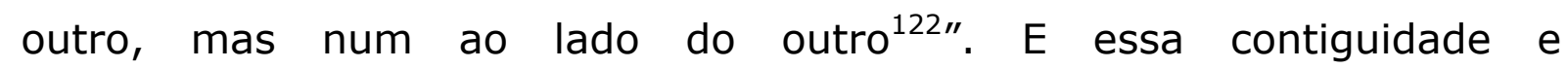
descontinuidade permite momentos nos quais aquilo que está separado se recombine "para formar uma nova intensidade e, talvez, possibilitar a eclosão de um verdadeiro outro"123.

O mesmo embate se dá nas análises de ambos sobre Kafka. O ato mimético na obra de arte tem o poder de romper tal racionalização e a linearidade da ordenação do mundo; no entanto, para Adorno mímesis não é natureza, mas realidade social e desvelamento da dimensão da alteridade. Na imitação ocorre um deslocamento do sempre-igual que é em si aterrador, pois nos coloca frente ao reconhecimento do Outro. "Proust estava familiarizado com o leve mal-estar suscitado pelo reconhecimento da semelhança com um parente longínquo. Em Kafka, o mal-estar se transforma em pânico."124 Quanto mais forte o impulso mimético - seja 0 do medo ${ }^{125}$ como 0 da felicidade originária, experimentada na dissolução das amarras da subjetividade e no contato com o outro - mais rígidas são as interdições a ele e mais forte o efeito de seu desvelamento.

O rigor com que os dominadores impediram no curso dos séculos a seus próprios descendentes, bem como às massas dominadas, a recaída em modos de viver miméticos começando pela proibição social dos atores e dos ciganos e chegando, enfim, a uma pedagogia que desacostuma as crianças de serem infantis - é a própria condição da civilização. A educação social e individual reforça nos homens seu comportamento objetivo enquanto

\footnotetext{
${ }^{121}$ GAGNEBIN, 1993, p. 76

122 Ibid, p. 84.

123 Ibid. p. 84.

${ }^{124}$ AsK, pág 249.

125 "A proteção pelo susto é uma forma de mimetismo. Essas reações de contração no homem são esquemas arcaicos da autoconservação: a vida paga o tributo de sua sobrevivência, assimilando-se ao que é morto" (DE, p. 168).
} 
trabalhadores e impede-os de se perderem nas flutuações da natureza ambiente. Toda diversão, todo abandono tem algo de mimetismo. Foi enrijecendo contra isso que o ego se forjou. ${ }^{126}$

Pode-se dizer que é possível ver as obras de Kafka de acordo com o conceito adorniano de arte como desafio ou negação da realidade, como forma de denúncia de suas contradições. O interessante é ver este desafio ocorrer não somente pela denúncia, mas também pelo uso da mímesis: uma "superconformidade $127 "$ que leva as imagens ao limite do absurdo para apontar a insustentabilidade do real, ao ponto deste horror e ameaça reais transformarem "o homem ou o animal cheio de medo num bicho imóvel, quase morto, cuja presença não é mais traída ao agressor por nenhum movimento" ${ }^{128}$.

Segundo tal interpretação, nesta imitação completa se camufla uma estratégia de sobrevivência. A indiferença dos personagens de Kafka acaba mostrando-se uma forma segura para lidar com o mundo que os rodeia, pois funciona como um tipo de imersão: ao se misturarem com os ambientes opressivos, os personagens buscam escapar da opressão que os ameaça.

Em A Metamorfose, isso é visível em dois momentos: o primeiro quando o despertador bate novamente às sete horas e Gregor deixa-se ficar quieto, "respirando suavemente, como se porventura esperasse que um repouso tão completo devolvesse todas as coisas à sua situação real e vulgar $^{129 " .}$. Depois, ao ser descoberto pelos hóspedes, com o desenrolar do drama vemos que

Durante todo esse tempo Gregor esteve deitado no lugar onde os inquilinos o haviam surpreendido. A decepção com o malogro do seu plano, mas talvez a fraqueza causada por muita fome, tornavam impossível que ele se movesse. Com

\footnotetext{
${ }^{126}$ DE, p. 169

${ }^{127}$ Cf. nota 73.

128 GAGNEBIN, 1993, p.86,

${ }^{129}$ M, p. 76
} 
uma certa clareza, temia já para o instante seguinte uma avalanche geral descarregada em cima dele e ficou aguardando ${ }^{130}$.

Se a normatização excessiva da sociedade é uma forma de interditar aquilo que rememore o processo mimético ${ }^{131}$, a obra de Kafka realiza, por seu caráter extremamente racional, a reelaboração desta mímesis em um tipo de linha de fuga ${ }^{132}$. O que não pode ser esquecido precisa ser elaborado: nossa natureza animal e simultaneamente o que nos faz humanos. A sociabilização - a sublimação das pulsões e da mímesis em direção ao trabalho - deixa um resíduo que não consegue ser eliminado ou esquecido. "A gênese social do indivíduo" - entendendo esta como a família, o trabalho e a organização - "revela-se no final como o poder que o aniquila. A obra de Kafka é uma tentativa de absorver isso"133.

Assim, o gesto mimético - e a reprodução do gesto como prosa, no caso específico de Kafka - está relacionado diretamente ao mundo, ao cotidiano e, de certa forma, à história: "Os gestos perpetuados são em

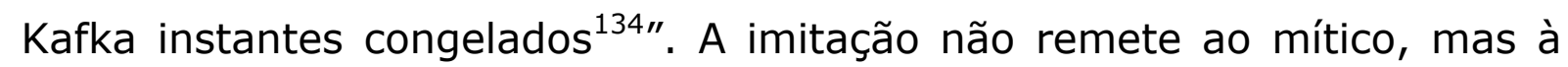
história, ao real.

É próprio da experiência traumática essa impossibilidade do esquecimento, essa insistência na repetição. Assim, seu primeiro esforço consistia em tentar dizer o indizível, numa tentativa de elaboração simbólica do trauma que lhes permitisse continuar a viver e, simultaneamente, numa atitude de testemunha de algo que não podia nem devia ser

\footnotetext{
${ }^{130}$ M., p. 30

${ }^{131}$ Conforme Adorno.

132 A escolha do termo remete propositadamente a Deleuze, pois tal ideia - a possibilidade de achar novas saídas a partir do que se apresentaria como dado ou imutável - constitui um dos pilares do pensamento político/estético deleuziano. Como o estranhamento é visto também por Adorno como uma forma de provocar um deslocamento no receptor, tirando-o da normatização do sempre-igual e abrindo novas formas de pensamento, pode-se usar o termo para ambos os autores.

${ }^{133}$ AsK, p. 249.

${ }^{134}$ AsK, p. 249
} 
apagado da memória e da consciência da humanidade ${ }^{135}$.

A questão da mímesis espelha simultaneamente a dificuldade das relações eu/outro e eu/mundo: a imitação/reprodução dos gestos como busca da semelhança e da proximidade com o outro ${ }^{136}$, mas também como uma estratégia de enfrentamento do medo e da ameaça que este mesmo outro representa: a sensação de desconforto que é derivada da contemplação da alteridade - e do reconhecimento desta alteridade dentro de si.

Para superar esta dificuldade de relacionamento que se apresenta, busca-se a semelhança máxima com o outro, chegando até mesmo ao ponto da caricatura, se necessário: mímesis como expressão do horror e do humor. A imitação, o medo e o riso são usados como estratégias de preservação, para que o indivíduo possa se fundir com a massa sem despertar suspeitas ou correr riscos. Assim, a escolha do macaco Rotpeter pela imitação, em Um Relatório para uma Academia, se mostra acertada: mimetizar é uma questão de sobrevivência social.

\subsection{Mutação/Sonho}

O caráter hermético dos escritos de Kafka não oferece apenas a tentação de contrapor abstratamente a ideia de sua obra à história - o que ele próprio faz, em longas passagens -, mas também a de retirar, por meio de uma profundidade barata, sua obra do âmbito histórico. Mas é precisamente como obra hermética que ela toma parte do movimento literário do decênio da Primeira Guerra Mundial,

\footnotetext{
135 GAGNEBIN, 1993, p. 99. Se para Benjamin a história só pode ser apreendida no momento em que se cristaliza na obra, o que nos remete também à noção de acontecimento, Adorno busca apreender a história na negatividade que a obra lhe impõe, dentro de um momento temporal que a cerca no qual "se mesclam o efêmero e a mesmice" (AsK, p. 249)

${ }^{136}$ A pantomima, pan-mimesis, é uma imitação completa e detalhada de um outro, assim como uma forma de comunicação e expressão que rompe a necessidade da palavra.
} 
que tinha Praga como um de seus pontos centrais, e a cujo ambiente intelectual Kafka pertencia. Somente quem conhece (...) consegue captar Kafka em seu horizonte autêntico, o do expressionismo. A sua mentalidade épica procurou evitar o gesto linguístico deste expressionismo. ${ }^{137}$

A assemblage de Kafka entre o teatro iídiche (no qual o gesto adquire uma função primordial) e as figuras expressionistas e surrealistas, materializada na relação gesto-palavra, evocam por vezes uma atmosfera de sonho, notadamente na passagem dos ambientes e nos pequenos detalhes que aparecem em suas descrições. O passeio de Josef $\mathrm{K}$. pelos cartórios do tribunal, onde chegou por uma pequena escada de madeira que saía do sótão do prédio muito comprido e alto na Juliusstrasse ${ }^{138}$ nos remete às imagens de Escher ${ }^{139}$ e do experimentalismo de Buñuel e Dali em Um Cão Andaluz.

A própria forma da narrativa aproxima mímesis e sonho, em uma descrição minuciosa e hiper-real do ocorrido: a negação do sonho e a oposição ao real, contudo, se dão pela hiperconformidade a estes dois elementos; o que é descrito pode até ser inverossímil, mas é descrito de forma verossímil e rigorosa. Mais do que isso, parece perfeitamente normal que as coisas sejam da forma apresentada; o sonho mostra-se, em outros instantes, como um realismo elevado a seu limite. Kafka deixa isso claro no início de A Metamorfose: "O que aconteceu comigo? pensou. Não era um sonho. ${ }^{140 " . ~ A d o r n o ~ o b s e r v a ~ q u e ~ " a o ~ l i q u i d a r ~ o ~ s o n h o ~}$ por sua onipresença, o épico Kafka levou o impulso expressionista tão longe quanto os líricos mais radicais ${ }^{141 "}$.

Ou seja, a atmosfera onírica que a narrativa assume destaca o estranho dela e confere realidade a este estranho. O princípio que opera aqui é o da inversão narrativa (ou referencial): em $A$ Metamorfose, em

\footnotetext{
${ }^{137}$ AsK, p. 258

${ }^{138}$ Conforme descrito no capítulo segundo de O Processo

${ }^{139}$ Como a litografia Relativity, de 1953.

${ }^{140}$ M. p.5

${ }^{141}$ AsK, p. 258
} 
vez da história transcorrer em direção ao clímax narrativo, ela já começa no ponto máximo de tensão - a transformação em inseto - e termina de uma forma anticlimática, com a morte de Gregor por inanição e a esperança em um futuro melhor por parte dos sobreviventes. "Ou seja, aqui a coisa narrada não caminha para o auge, ela se inicia com ele ${ }^{142 "}$.

O efeito de inversão também ocorre na própria abertura da narrativa, pois Gregor não acorda de um pesadelo, e sim para o pesadelo. A relação com a noite e $o$ ato de dormir/acordar também está presente no início de $O$ Castelo ${ }^{143}$ e de $O$ Processo ${ }^{144}$, como se os personagens acordassem dentro de um mundo onírico onde os absurdos se sucedem. Mas a inversão só se completa se levarmos esse jogo de oposições a um limite novo: se o "comum" é o onírico, o incomum, um "incomum estranhamente familiar", é real. Para Adorno,

pelo contraste com este sonho todo o resto é confirmado como realidade. (...) Tudo o que se assemelha ao sonho e a sua lógica pré-lógica é eliminado, e por isso o próprio sonho é eliminado. Não é o monstruoso que choca, mas sua naturalidade ${ }^{145}$.

A realidade distorcida, leitmotif do expressionismo, desvela o real e o assombro do humano capturado em um jogo de forças que parecem, à primeira vista, não fazer sentido - exigindo, portanto, um grande esforço de compreensão daquele que recebe o impacto da obra. Adorno apresenta a tese de que tais elementos são fundamentais na apreensão da obra, salientando a capacidade de Kafka em descrever os ambientes que imagina.

Somente o visível pode ser narrado, mas nesse processo o visível torna-se completamente estranho, transforma-se em

\footnotetext{
142 CARONE, 2009. p.32.

${ }^{143}$ Ao chegar tarde da noite ao vilarejo, K. acaba por se alojar na sala da pousada, e seu sono é interrompido pelos curiosos camponeses.

144 Josef K. é detido logo depois de acordar.

${ }^{145}$ AsK, p. 246
} 
imagem, no sentido mais literal da palavra. Kafka salva a ideia do expressionismo não ao se esforçar em vão para escutar os sons primordiais, mas ao transferir para a literatura os procedimentos da pintura expressionista. Ele se relaciona com essa pintura da mesma maneira que Utrillo com os cartões-postais, que teriam servido de modelo para suas ruas cobertas de gelo. Diante do olhar de pânico que retira dos objetos toda carga afetiva, essas ruas se petrificam em algo diferente: nem sonho, que se deixa apenas falsear, nem macaqueamento da realidade, mas sim a imagem enigmática dessa realidade, composta de fragmentos dispersos ${ }^{146}$.

A pista para localizar estes fragmentos do real está nas elipses narrativas que surgem como consequência de seu estilo (ou forma) de escrita/escritura: "descontínuo, labiríntico, com vazios que o leitor deve

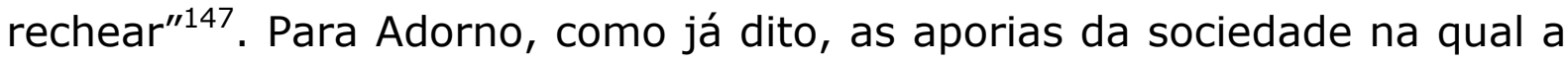
obra surge retornam como problemas inerentes de sua forma. Uma sociedade na qual o absurdo é a regra se vê "refletida" em uma narrativa na qual o absurdo é elemento constitutivo, assim como a "suspeita universal, profundamente incrustada na fisionomia da época contemporânea ${ }^{148 \prime \prime}$. Sob este aspecto, a escrita kafkiana comunica a necessidade do questionamento perante o que parece natural; ou, dito de outro modo: do contraste entre o esperado (ou aquilo que se está acostumado a ver) e o encontrado na leitura do texto resulta o potencial de ruptura/negatividade da obra kafkiana.

O leitor deveria se relacionar com Kafka da mesma forma como Kafka se relaciona com o sonho, ou seja, deveria se fixar nos pontos cegos e nos detalhes incomensuráveis e intransparentes. O fato de que os dedos de Leni estejam ligados por uma membrana ou que os executores pareçam tenores são coisas mais importantes do que as digressões sobre as leis ${ }^{149}$.

\footnotetext{
${ }^{146}$ AsK, p. 261

${ }^{147}$ MALDONADO, 2006, p. 136.

${ }^{148}$ AsK, p. 263

${ }^{149}$ AsK, p. 246. A visão de Adorno sobre a relação Kafka-sonho poderia sugerir que o onírico contivesse o significado oculto de Kafka, mas é possível também conjecturar em outra direção: a de que os detalhes do sonho operam a relação entre texto e leitor; ou seja,
} 
Se em muitos momentos os textos de Kafka assumem este caráter supostamente onírico, é exatamente deste caráter que surge a possibilidade de entendimento do real: devemos observar com especial atenção aquilo que não deveria estar ali, indagar o porquê de aparecerem. Tudo que nos cerca deve ser entendido de forma literal, sem espaço para duplas interpretações. Este procedimento faz com que a narrativa transmita humor, prazer e terror simultaneamente. As situações se sucedem muitas vezes sem um elo claro de ligação; esta aparente falta de nexo narrativo cria o efeito do absurdo, triste, assustador e engraçado ao mesmo tempo. O fio condutor, para Adorno, não reside no que é descrito e sim na lógica que a narrativa segue ${ }^{150}$. Nas palavras do próprio Kafka, "o sonho revela a verdade atrás da qual se encontra o pensamento"151.

Ao observarmos um texto como Um Sonho ${ }^{152}$, o homem que escreve o nome de Josef $K$. na lápide teria a posição daquele que desvela a

que estes detalhes contribuem tanto para o entendimento do significado da obra como para o estabelecimento de uma dinâmica entre o leitor e o texto kafkiano. Permitem não apenas interpretar o texto, mas construir o significado a partir desta dinâmica. Nesta acepção, a análise de Adorno aproxima-se das de Deleuze e Guattari porque, para ambos, tão importante como o porquê do sonho na produção kafkiana é o para quê ele funciona na obra.

${ }^{150}$ Carone, referência na tradução de Kafka no Brasil, segue a mesma linha quando declara que "a importância da obra, toda a sua força, não vem propriamente da história contada, mas sim da sua coerência e da sua extraordinária unidade, do seu timbre particular inconfundível. (...) na verdade não se ouve senão essa voz, e essa voz é inteligível de imediato, mas não é possível dizer o que ela de fato exprime, apesar da angústia, da desolação, do humor e da falta de saída do entrecho". (Entrevista ao jornal O Estado de São Paulo, edição de 02 de julho de 2000.)

${ }^{151}$ S, p. 7. Guattari, ao analisar os sonhos de Kafka registrados em suas cartas, anotações e diários, nota que o estágio de sonho é distinto tanto do sono como da vigília, e que Kafka se queixava constantemente do esgotamento ao que o sonhar o levava, contraponto ao vigor que o escrever the trazia. O estágio entre sono e vigília pode tanto se referir ao onírico do sonho como o da escrita, momentos nos quais "o sentido colapsa". (PELBART, p.5)

${ }^{152}$ Este texto de Kafka foi originalmente pensado para ser um dos capítulos de O Processo, mas foi eliminado pelo autor. Adorno considera que o intento de Kafka ao retirar o capítulo em questão foi o de que a fronteira entre real e imaginário permanecesse nublada. Se o sonho de Josef K. contemplando sua sepultura se mantivesse na obra, não apenas o final estaria comprometido como tornar-se-ia evidente que o que ocorria era real, incluindo todos os movimentos de suspensão da descrença, as salas contíguas, as membranas entre os dedos, etc. Tais elementos fantásticos, agora desprovidos da "aura dúbia", perderiam o sentido na obra. (cf. AsK, p. 243) 
verdade pela palavra ${ }^{153}$. O coveiro é o próprio escritor, pois este sabe o destino da personagem e o escreve na obra, sabe a verdade da obra. Somente o escritor sabe o real significado ou intenção do que escreve; por não se ter a possibilidade de compreender isto, o único ponto de referência para o leitor se encontra em admitir a palavra escrita como a realidade em si. O sonho é o real e aquilo que está descrito na narrativa é a única realidade ou verdade que temos, mas é uma verdade incompleta e imprecisa. O despertar de Josef $\mathrm{K}$. ao final do conto já lhe dá a certeza de seu destino, assim como a nós, "participantes" da trama. Assim, invertese a lógica sonho-realidade: acordamos para o pesadelo e sonhamos com o destino mais real e inexorável.

\subsection{Humor}

A obra de Kafka também apresenta uma dimensão pouco explorada: ao descartar as interpretações mais comuns sobre sua obra, assume-se que o entendimento sobre ela deve surgir da leitura do texto e não da acomodação deste a posições predeterminadas. "A autoridade de Kafka é a dos textos ${ }^{154 \prime}$. Recorde-se a crítica de Adorno às interpretações correntes do texto kafkiano, insistindo numa literalidade de interpretação ${ }^{155}$ que nos leva ao chiste em algumas das situações

\footnotetext{
${ }^{153}$ Além da talvez óbvia referência aos escritos e à religião judaica que isso possa significar, podemos ver este "sonho dentro do sonho" como um exercício de metalinguagem, uma referência de Kafka ao fato da literatura permitir a criação de um universo onde onírico e real se amalgamam e no qual o homem que escreve na lápide é a representação do próprio Kafka. O conto é um sonho que ocorre dentro de uma ficção.

${ }^{154}$ AsK, p.242

${ }^{155}$ É interessante observar que o texto de Deleuze/Guattari sobre o autor checo também defende tal literalidade ao descartar de forma contundente o psicologismo nas leituras do autor, o que será tratado no decorrer do trabalho. Estranhamente, Adorno considera que Kafka opera fundamentalmente e com maestria por alegorias (AsK, p. 242, cf. nota 75) e tais alegorias não conduzem a uma determinação definitiva de sentido do que está escrito, no que acompanha o pensamento de BENJAMIN (1985): "a palavra desdobramento tem duplo sentido. $O$ botão se desdobra em flor, também o papel dobrado em barco que se ensina a criança a fazer desdobra-se em folha lisa. E esse segundo "desdobramento" é adequado, com efeito, à parábola, ao prazer do leitor ao alisá-la, até que seu significado caiba na palma da mão. Mas as parábolas de Kafka desdobram-se no primeiro sentido, como o botão se
} 
descritas. Tal literalidade é um processo que ocorre em dois planos que se entrecruzam: forma e conteúdo (ou enunciado e enunciação ${ }^{156}$ ) que, para Adorno e Benjamin, são uma reminiscência da tradição judaica e da leitura da Torá, mas que também remete a elementos de comédia. Isso é notado por Adorno em sua análise ${ }^{157}$.

desdobra em flor." (pp. 147-148). Por este critério, seria possível falar na existência de uma "literalidade alegórica" - ou de "alegorias literais" - enquanto figura de linguagem per se que definiria a forma da obra kafkiana? Um termo desses deve ser usado com sérias reservas, por ser aparentemente paradoxal. Porém, se podemos entender literalidade como uma correspondência direta entre signo e significado (assim como alegoria como a alusão a um significado a partir de um deslocamento do sentido do signo utilizado), talvez vejamos um estranho fenômeno em Kafka: a compreensão do significado do que é escrito só é possível a partir da interpretação literal de figuras alegóricas, como um homem inseto ou animais falantes. Para entendermos o significado de suas alegorias, precisamos interpretá-las de forma literal. Isso adiciona à equação a figura do intérprete, estabelecendo um terceiro plano de funcionamento do dispositivo literário. TADEU (2005, p. 1331 et seq.), ao analisar a abordagem de Deleuze sobre a diferença entre metáfora e literalidade, observa que para o autor francês " a metáfora é uma operação linguística, uma palavra pela outra, enquanto a literalidade, o 'ao pé da letra', propõe justamente uma operação extralinguística, material, empírica, uma coisa pela outra. A primeira, como operação linguística supõe uma identidade, uma semelhança, uma similitude, uma equivalência de sentido, uma equivalência semântica. Não saímos, aqui, da significância, apenas trocamos uma por outra. A segunda, como operação material, supõe um isomorfismo, uma equivalência de funcionamento, uma equivalência pragmática" (p. 1335). Se o realismo de Kafka, conforme Carone, opera na junção entre "o que as coisas são e como elas são percebidas pelo olhar alienado" (Cf. nota 38), a alegoria surge a partir de tomarmos ao pé da letra aquilo que está escrito, por mais absurdo que isto pareça.

156 ANSCROMBE e DUCROT (2010, passim) definem enunciação como "a atividade de linguagem exercida por aquele que fala no momento em que fala", o que exige que aquele que ouve o que é dito tenha também a compreensão dos signos e códigos usados por aquele que enuncia. $O$ produto do ato de enunciação é o enunciado, sequência acabada de palavras de uma língua emitida por um falante. Do ponto de vista da estilística, TODOROV (1982, passim) distingue duas divisões: a do enunciado que se ocupa do aspecto verbal, suas particularidades fônicas, morfológicas, semânticas, sintáticas; e a da enunciação, que se ocupa da relação entre protagonistas do discurso: locutor, receptor, referente.

157 Tal relação também é sugerida na leitura deleuzoguattariana. Deleuze apresenta outra dimensão de Kafka como complemento ou contraponto à ideia de abandono, relacionada à sua visão (baseada em informações de Max Brod, responsável pela publicação dos textos de Kafka após sua morte) de que há uma intencionalidade no absurdo kafkiano, e esta intencionalidade busca o humor e não a tristeza. Para Deleuze, em sua argumentação para refutar as leituras ditas densas, Kafka exige uma leitura bem-humorada para adentrarmos o rizoma de sua obra, mas sem deixar de reconhecer seu caráter político e seu potencial de experiência. Assim, rir ao ler Kafka seria uma verdadeira subversão em relação às leituras tradicionais, tidas por ele como interiorizadas e por isso mesmo emasculadas do potencial político e social que a literatura menor possuiria. Se o mundo surge como um monolito absurdo perante os olhos dos personagens de Kafka, a saída para este mundo não é o desespero e a melancolia, mas o riso sarcástico. Conforme Deleuze, "nunca houve um autor tão cômico e alegre do ponto de vista do desejo; nunca houve autor mais político e social do ponto de vista do enunciado. Tudo é riso, a começar pelo Processo. Tudo é político, a começar pelas Cartas a Felice" (K., p. 42) 
Ocasionalmente, a literalidade chega, por associação de palavras, ao extremo do chiste. Assim, por exemplo, na historia da família de Barnabás em O Castelo, onde está dito que o funcionário Sortini teria ficado 'bei der Spritze" (junto à bomba) na festa do corpo de bombeiros. A expressão coloquial alemã, que designa a fidelidade ao dever, é levada a sério. O respeitável personagem fica ao lado da bomba dos bombeiros, ao mesmo tempo que se alude, como nos atos falhos, ao desejo grosseiro que leva o funcionário a escrever a carta fatal a Amélia ${ }^{158}$

A leitura ao pé da letra do que é descrito remete a elementos do cinema mudo, como a perseguição policial na chegada ao edifício onde Brunelda vive (em O Desaparecido/Amerika). Porém, remete também ao dito "sal judaico159" - um humor sarcástico, que mostra a capacidade de rir de suas próprias mazelas e características, historicamente relacionado a este povo, mas que ganhou corpo na Europa oriental no final do século XVIII ${ }^{160}$ como forma de lidar com a dura realidade.

Segundo Feldman (2009), o humor judaico é "uma tentativa de nomeação do que não satisfaz ${ }^{161 " ~ n a ~ c u l t u r a ~ e ~ c o t i d i a n o ~ d o ~ p o v o ~ j u d e u, ~}$ mas que opera de uma forma mais simples e eficaz do que a pura denúncia dos motivos desta insatisfação, pois tal oposição pura e simples envolveria um conflito consigo mesmo e com suas origens. Com ele, o indivíduo "tem a chance de se separar de sua cultura e demonstrar seu desagrado sobre alguns temas que o cercam, sem que haja uma punição por isso ${ }^{162 " .}$. É mais simples lidar com questões individuais ou de grupo por meio do riso do que pela ruptura.

Considerando que entre suas características se encontram a ênfase na incongruência, o recurso a interpretações literais, absurdas e a crítica ácida da relação entre os indivíduos e as estruturas de poder, do

\footnotetext{
${ }^{158}$ AsK, p. 243

${ }^{159}$ Revista Morashá ed. 51 - dezembro de 2005. Publicação do CBSp. São Paulo. SP

160 Cf. BRUMER, A. O Humor Judaico em Questão. In WebMosaica - Revista do Instituto Cultural Judaico Marc Chagall. V1 N.2 - Jul-dez 2009

${ }^{161}$ FELDMAN, L. Humor judaico: o sorriso entre lágrimas. Webmosaica. 2009, p. 27-28

162 ibidem
} 
autoritarismo e das normas que parecem não ter sentido para o homem comum, não é um tipo de humor que apele para o riso fácil, para simples jogos de palavras de conotação dúbia ou duplo sentido, pastelão ou de personagens caricatos com frases mordazes na medida certa para agradar ao leitor comum, como o humor de seriados de costumes com suas crianças mais espertas do que adultos ou idosos que repetem imprecações a todo momento: "o humor judaico induz à reflexão. É um humor reservado, não provoca o riso fácil, a gargalhada e sim um pensativo sorriso ${ }^{163 "}$.

Tais elementos influenciaram sobremaneira os espetáculos teatrais da época, além de serem facilmente reconhecíveis na prosa kafkiana. Sabe-se que em 1911 Kafka assistiu a apresentações de teatro iídiche em Praga $^{164}$ e que a amizade com Isaac Löwy, ator da companhia que se apresentou na cidade, teve tremenda influência em sua literatura. O í́diche tem entre um de seus trunfos o uso pouco ortodoxo do texto, pois não raro os artistas, a partir de comentários (espontâneos ou não) da plateia, improvisavam diálogos nos quais o absurdo era a tônica. O dito humor judaico é rico em passagens nas quais, por meio da crítica irônica, inteligente e até excessiva aos arquétipos de sua cultura, busca o esvaziamento dos estereótipos atribuídos ao grupo por outras coletividades. De uma aparente submissão, decorre a afirmação da própria força. Com isto em mente, uma passagem do texto de Adorno se torna mais clara:

O mundo é antes revelado como sendo tão absurdo quanto o seria para o intellectus archetypus. (...). Mas a ironia destes traços, muitas vezes notada, faz parte do próprio conteúdo doutrinário. Kafka não pregou a humildade, mas um comportamento mais testado contra o mito: a astúcia. Para ele, a única, mais fraca e menor possibilidade de o mundo não ter razão é a possibilidade de lhe dar razão. (...). O humor de Kafka deseja reconciliar o mito através de uma

\footnotetext{
163 SCLIAR, in BRUMER, p. 8

164 Kafka comentou extensivamente sobre tais apresentações, assim como sobre seu envolvimento com duas atrizes e sua amizade com o ator Isaac Löwy, em seus Diários.
} 
espécie de mímica. (...) Como há milhares de anos, Kafka procura a salvação pela incorporação da força do inimigo ${ }^{165}$.

Se a observação de que Kafka "incorporou à escrita o sistema burocrático em que vivia, recriando na ficção o estilo protocolar, como forma de registro e ironia ${ }^{166 " ~ f o r ~ a n a l i s a d a ~ s o b ~ e s t e ~ a s p e c t o, ~ e s t a ~}$ absorção surge como denúncia, crítica e resistência ao mundo que cerca o autor de Praga.

Ao usar de fórmulas do humor judaico - a "salvação pela força do inimigo ${ }^{167 " ~-~ p a r a ~ t a l ~ d e n u ́ n c i a, ~ K a f k a ~ c o m b a t e ~ o ~ i s o l a m e n t o ~ d a ~ c u l t u r a ~}$ judaica em direção a um terreno acima de culturas regionais, em direção a temas que transcendem fronteiras nacionais ${ }^{168}$. O dito absurdo de suas obras opera como denúncia do absurdo do mundo. Um combate à burocratização por meio de um texto rígido como um relatório. Por isso o falsum é o index sui: atesta-se por si e, por meio disso, revela a verdade oculta.

Parte do enigma reside na denúncia e definição do real por meio do absurdo, do caricato e do cômico que sua interpretação ao pé da letra proporciona. Um conto como O Novo Advogado é um bom exemplo de como o absurdo pode ser usado como ferramenta cômica e ao mesmo tempo crítica. O mais absurdo talvez não seja o fato de Bucéfalo, o cavalo de Alexandre Magno, se tornar advogado, mas a compreensão das pessoas de que, "sendo a sociedade moderna aquilo que é ${ }^{169 ", ~ o ~ p o b r e ~}$ animal não tinha mesmo outra alternativa na vida. Ou seja, dito de forma

\footnotetext{
${ }^{165}$ AsK. p. 268

${ }^{166}$ CARONE, 2000. Entrevista a OESP. 02/06/2000

167 AsK., p.168.

168 A obra de Kafka apresenta características que permitem alinhá-la ao conceito de Weltliteratur (Cf. CARONE, 2005, p. 72). Para Goethe, tal literatura tem como característica aquilo que "há em comum entre as diferentes culturas, sem que se apague a individualidade que se baseia em diferenças nacionais" (KESTLER, 2010), não se constituindo em uma homogeneização cultural nem na superioridade de uma cultura ou literatura sobre as demais. O que é comum a todos, este caráter humano, é o que está em primeiro plano neste tipo de literatura, que não é restrita nem por questões geográficas nem mesmo pelas inúmeras diferenças entre as culturas.

${ }^{169}$ KAFKA, 1988, p. 69
} 
popular, o mundo não está fácil nem para quem, digamos assim, tem estirpe ou amigos poderosos (no caso de Bucéfalo e Alexandre, muito poderosos). Ao pé da letra, podemos ler também que até mesmo um cavalo conseguiria trabalhar como advogado à época de Kafka, o que nivelaria os advogados a animais ${ }^{170}$.

A ironia kafkiana mostra a impossibilidade de separação entre o negativo e o positivo - uma coisa é definida também pela determinação de sua negação ${ }^{171}$. Assim, a ironia funciona como uma forma de lidar com o fato de que a identidade de um indivíduo ou de um grupo se forma, muitas vezes, pela oposição ou contraste em relação a outros grupos ou ideias. No caso de Kafka, pode-se pensar que ele pertence a vários grupos simultaneamente e, de certa forma, ele é um estrangeiro em todos eles. 0 humor surge em um mundo no qual o que se faz mais visível é o horror e a opressão, o que nos remete ao insólito ${ }^{172}$ de uma risada que exatamente pelo seu exagero transcende a simples diversão: uma expressão - o riso - que transcende a palavra escrita ${ }^{173}$.

\footnotetext{
170 Visto que Kafka era advogado, o conto torna-se irônico e um pouco autodepreciativo exatamente como as características já apresentadas do humor judaico.

171 "Ele [Kafka] é o criptograma da fase final e resplandecente do capitalismo, que Kafka excluiu para determiná-la mais precisamente em sua negatividade". (AsK, p. 252). Importante salientar a coincidência de análise entre Adorno e Deleuze sobre a obra kafkiana como retrato da passagem de modelos na sociedade; no caso do francês, a passagem entre sociedades disciplinares e de controle.

172 Insólito este que pode ser relacionado ao inquietante conforme FREUD, como veremos no capítulo 4 - Das Unheimliche.

${ }^{173}$ Tanto Adorno como Deleuze notam a importância do teatro iídiche em Kafka e sua capacidade de comunicar via códigos corporais. No rompimento da palavra, em si uma experiência de linguagem, se instala a capacidade de resistência: para o filósofo alemão, resistência como denúncia das contradições da sociedade que suporta a obra, como aquilo que surge a partir do que se mostra mais roto e arruinado na vida social. O conceito de ruína em Adorno, assim como em Benjamin, remete ao eco. Se as questões de uma sociedade se encontram imbricadas na obra de arte, também é possível rastrear aquilo que resultou no surgimento dessas questões, os resíduos de cada fase na história. Daquilo que se mostra destruído, buscar novos significados. Para PEREIRA (2007), Benjamin saberia que "o homem moderno é um indivíduo destituído de experiência; é, portanto, um ser cuja condição de perda se anuncia num mundo de escombros, em que se veem perfilados em ruínas os grandes valores antigos. O mundo moderno é um mundo cuja história foi desagregada, nele o passado já não se encontra contido no presente, remanesce apenas como uma lembrança difusa de fatos que, para ele, não lhe dizem mais respeito". Já para Deleuze, a resistência surge como multiplicidade - ou rizoma - que forma a máquina de escritura de Kafka, como potência de vida que aparece pelas brechas do campo majoritário do pensamento, pelos interstícios de um sistema dominante. Em ambos os casos, a resistência se mostra como
} 


\section{Desta maneira}

O escritor torce a linguagem, fá-la vibrar, abraça-a, fende-a, para arrancar o percepto das percepções, o afeto das afecções, a sensação da opinião - visando, esperamos, esse povo que ainda não existe. (...) ...é a tarefa de toda arte (...). Um monumento não comemora, não celebra algo que se passou, mas transmite para o futuro as sensações persistentes que encarnam o acontecimento: o sofrimento sempre renovado dos homens, seu protesto recriado, sua luta sempre retomada. Tudo seria vão porque o sofrimento é eterno, e as revoluções não sobrevivem à sua vitória? Mas o sucesso de uma revolução só reside nela mesma, precisamente nas vibrações, nos enlaces, nas aberturas que deu aos homens no momento em que se fazia, e que compõem em si um monumento sempre em devir, como esses túmulos aos quais cada novo viajante acrescenta uma pedra. ${ }^{174}$

O "surreal" dos ambientes, as atitudes egóicas e os gestos muitas vezes desprovidos de lógica dos personagens, a sisudez burocrática do texto e a aparente fragmentação da narrativa levam o leitor a um ponto em que ele se questiona, em um riso sardônico, sobre se realmente aquilo não poderia ser de outra forma, fazendo-o, por um instante, contrapor esta visão com a sua percepção de mundo. Quem, ao ler o discurso devastador de Josef $\mathrm{K}$. frente ao juiz de instrução em $O$ Processo, não se imaginou, nem que seja por um instante, realizando algo semelhante diante de uma situação na qual se sente flagrantemente desrespeitado?

voz/expressão daquilo que não está visível de imediato no tecido social predominante, apesar de que no pensamento de Adorno e Benjamin temos a rememoração como estratégia e, no de Deleuze, como instância do novo.

174 DELEUZE, 1992, pp. 228-229. É interessante a analogia possível entre a palavra e o túmulo, visto que sèma, da qual derivou signo e semântica, tem como significado originário túmulo. Conforme GAGNEBIN (2006), isto é "um indício evidente de que todo o trabalho de pesquisa simbólica e de criação de significação é também um trabalho de luto. $E$ que as inscrições funerárias estejam entre os primeiros rastros de signos escritos confirma-nos, igualmente, quão inseparáveis são memória, escrita e morte," (p. 38). Se aplicarmos esta relação ao texto deleuziano, teria a palavra - discurso, literatura menor - a missão da rememoração, de nos fazer lembrar da necessidade de irmos em frente, da possibilidade de um devir? 
O mundo abre-se ao protagonista e desta forma tudo pode acontecer: nas dobras do "surreal" descortina-se o terror e o desamparo da existência. Porém, isso ocorre de uma forma contida, sem rompantes ou descontrole: um certo humor negro surge nas sombras, aparece nos detalhes do viver e expõe inapelavelmente que nossa compreensão usual da realidade e da existência está inequivocamente equivocada, pois está contaminada pelo amortecimento do reconhecimento de si e do outro, ou seja, pela regressão da razão.

Imaginem a arte de Kafka como um tipo de porta, e a nós, leitores, batendo nesta porta, mais e mais, não apenas querendo entrar, mas precisando disso desesperadamente. Não sabemos o porquê, mas podemos sentir este desespero absoluto para entrar, batendo e empurrando e chutando, etc. Então, finalmente, a porta se abre...e se abre para fora: nós estávamos o tempo todo dentro ${ }^{175}$.

Estamos do lado contrário da porta. E Kafka sorri, educadamente, de nossos esforços infrutíferos.

\subsection{Horror}

Pode-se dizer, então, que o humor encontrado em Kafka a partir desta interpretação possui um componente de horror em sua estrutura, "um horror que antes se imiscuía quase imperceptivelmente em cada palavra"176. Mas se esse horror estava oculto, de que forma ele se desvela à medida em que lemos Kafka? Como a linguagem efetua este desvelamento na estrutura da obra? Para localizar este componente de horror, é preciso conceituar o que quer se dizer com tal expressão. Como já visto, não é possível reduzir a obra kafkiana a um expoente da

\footnotetext{
${ }^{175}$ WALLACE, 1998.

${ }^{176}$ AsK, p. 251
} 
literatura fantástica ou de horror do início do século $X X^{177}$. O componente de horror, assim como do fantástico em sua obra, está vinculado a outra problemática: a do irrepresentável, o que nos perturba; o que não pode ser descrito facilmente.

Uma observação de Kafka datada de 25 de outubro de 1915 para seu editor, Kurt Verlag, mostra a intenção clara do escritor em buscar o impacto do irrepresentável na imaginação de seu leitor:

Prezado Senhor: $O$ sr. mencionou recentemente que Ottomar Starke será o autor de ilustrações para A Metamorfose. Na medida em que conheço o estilo do artista, essa possibilidade me causou um pequeno e talvez desnecessário receio. Ocorreu-me que Starke, como ilustrador, poderia tentar desenhar o inseto propriamente dito. Isto não, por favor, não! Não quero impor-lhe restrições, mas apenas fazer este pedido devido ao conhecimento mais profundo que tenho da história. $\mathrm{O}$ inseto não pode ser representado. Não pode sequer ser visto à distância. ${ }^{178}$

Há um descompasso entre a experiência do horror e sua representação, já que esta não é capaz de abrangê-lo totalmente ${ }^{179}$. Da mesma forma, a representação funciona como um sistema de ordenamento da realidade que nos cerca. Por isso, o acontecimento extraordinário, que nos provoca pasmo, estranhamento ou horror, põe em

\footnotetext{
${ }^{177}$ Cf. o tópico 2.1

178 JESUS, 2011, p.5

179 Um problema crucial da filosofia, a relação entre realidade, pensamento e representação obriga-nos a analisar a real possibilidade de apreendermos algo pela consciência. $\mathrm{Na}$ separação clássica entre sujeito e objeto do conhecimento, a representação funcionaria como o elo entre o representante (o sujeito) e o representado (o objeto): "A noção de representação tem sido empregada, em termos gerais, para designar a forma sob a qual algo se apresenta, como distinta da simples apresentação de alguma coisa; enquanto tinha a ver com uma atitude cognoscitiva, a dita noção se referia à maneira segundo a qual um sujeito, ou um meio de representação, capta algo que se the apresenta" (ARNAO, p. 188189). Isso também vale para a problemática do sujeito, já que este é uma representação do ser ou de si. A representação se mostra sempre incompleta ou não-correspondente ao objeto representado, seja pela impossibilidade de separação completa entre quem sabe e $o$ que se sabe (entrando em um terreno caro a Bergson) como na afirmação kantiana de que somente podemos conhecer as representações, e não as coisas em si, o que indica uma diferença categorial entre elas.
} 
questão "a representação que temos do mundo, pois desestabiliza toda a compreensão que a representação propicia, visto que ela é um princípio de inteligibilidade, de razão. ${ }^{180 \prime \prime}$

O despertar de Gregor Samsa em A Metamorfose é um exemplo de acontecimento extraordinário no qual a perda de sentido, a perda da representação, se dá de forma imediata: a sentença "O que aconteceu comigo ${ }^{181 " ~ e ́ ~ e x e m p l a r . ~ O ~ d e s c o n h e c i d o ~ n a ̃ o ~ e s t a ́ ~ a p e n a s ~ a ̀ ~ f r e n t e ~ d o ~}$ protagonista, como futuro: é constitutivo de seu presente e de seu passado - de sua identidade ou representação de si. Paradoxalmente, o efeito de tal acontecimento extraordinário é maior no gerente e na família do que no próprio Gregor em um primeiro momento, visto que este, ao abrir a porta

ouviu o gerente soltar um "oh" alto - soava como o vento que zune - e então Gregor o viu também: era o mais próximo da porta e comprimia a mão sobre a boca, enquanto recuava devagar, como se o impelisse uma força invisível que continuasse agindo de modo constante. A mãe - apesar da presença do gerente, ela estava ali com os cabelos ainda desfeitos pela noite, espetados para o alto - a principio fitou o pai com as mãos entrelaçadas, depois deu dois passos em direção a Gregor e caiu no meio das saias que se espalhavam ao seu redor, o rosto totalmente afundado no peito. O pai cerrou o punho com expressão hostil, como se quisesse fazer Gregor recuar para dentro do quarto, depois olhou em volta de si, inseguro, na sala de estar, em seguida cobriu os olhos com as mãos e chorou a ponto de sacudir o peito poderoso. ${ }^{182}$

Nota-se a ausência da descrição do estado de Gregor por parte daqueles que o viram - e isso a torna mais vívida. O horror que não é dito é mais assustador do que o que é mostrado de forma explícita, assim como a perda da referência de si é mais chocante para o outro do que para o próprio Eu. Enquanto Samsa tenta argumentar, o gerente, em completo desespero

\footnotetext{
${ }^{180}$ FAVARETTO, p. 19

${ }^{181}$ M., p.7

${ }^{182}$ M., p.24
} 
tinha virado as costas e só Ihe dirigia o olhar por cima dos ombros trêmulos, com os lábios revirados. E durante a fala de Gregor não ficou parado um instante, recuando sem perder Gregor de vista, muito gradualmente, em direção à porta, como se houvesse uma proibição secreta de deixar a sala. Já estava na ante-sala e, pelo movimento súbito com que pela última vez tirou o pé do chão da sala de estar, seria possível acreditar que acabava de queimar a sola do pé. Na antessala, entretanto, esticou longe a mão direita, no sentido da escada, como se lá o aguardasse uma salvação decididamente extraterrena ${ }^{183}$.

A incapacidade de comunicação entre Gregor e o restante do mundo, seja pela incompreensibilidade do que é dito entre eles como da recusa em estabelecer contato (por parte do gerente e, em muitos momentos, da família) retiraria a possibilidade de se lidar com a situação gerada pela metamorfose. O incomunicável é o indizível, o inominável. 0 horror não se comunica, se vive. E o fato de não poder ser descrito o acentua: a linguagem - ou melhor, sua limitação - é fundamental para isso.

O horror poderia ser entendido como a realidade sem filtro: o simples fato de organizarmos a linguagem para expressar o que se sente ou contempla cria uma mediação entre o fato e o entendimento. Se o horror "é o fundo das coisas, a cultura e a linguagem (a arte) estariam aí para contê-lo184". Com isto em mente, a ausência de comunicação/linguagem entre Gregor e sua família torna a situação mais angustiante, incontida e "real". De forma similar, a escrita rígida de Kafka, a dita pobreza do léxico utilizado e a forma pouco usual de organização de sua narrativa acabariam por possibilitar uma melhor representação deste fundo exatamente por deixar espaços abertos ao leitor. A literalidade em cada palavra não engessa o texto ou restringe sua compreensão.

\footnotetext{
${ }^{183}$ M., pp 26-27

${ }^{184}$ WARIN, apud FAVARETTO, p. 20
} 
Ao interpretar figuras de linguagem de forma literal, aparentemente retirando delas seu caráter alegórico, Kafka as ressignifica, expondo a falência da linguagem como forma de contenção deste horror. O horror se torna explícito por meio da literatura que deveria, em sentido contrário, impedir seu desvelamento. 


\section{DAS UNHEIMLICHE}

O manejo da técnica da alegoria por Kafka cria um espaço de estranhamento em sua narrativa. Somando-se este fato às estranhas figuras nas quais o humano e o inumano se confundem, a inquietação gerada permitiria uma reflexão sobre categorias filosóficas tão díspares como o sublime, a subjetividade e a mímesis? O estranhamento causado pelos textos do autor de Praga pode, à sua maneira, ser um indicativo da presença de tais categorias na obra. A chave seria o conceito de inquietante, uma ruptura entre o familiar e o inusitado.

Cabe, então, uma análise dos elementos constitutivos deste estranhamento e o mapeamento de sua função na obra de Kafka, que desvela o insólito a partir do banal. O segredo estaria não no que se mostra, e sim no que se oculta, no irrepresentável e no não-representado na obra?

\subsection{Do sublime ao inquietante}

Fazer o negativo é nosso dever. O positivo já nos foi dado ${ }^{185}$.

Os textos de Kafka, talvez ao contrário do que normalmente acontece com outras obras artísticas de valor reconhecido, não provocam uma sensação de satisfação da Razão ou um arrebatamento dos sentidos. São feitos de interditos ${ }^{186}$, de pequenos ambientes ${ }^{187}$. Da sensação de

\footnotetext{
${ }^{185}$ Aforismo 27, in AsK.p.269

186 A porta e o guardião em Diante da Lei, uma interdição tanto no movimento do protagonista como um tipo de linguagem cifrada, algo entre-dito, com significado nas entrelinhas.

${ }^{187}$ As salas apertadas e sem ventilação de O Processo são exemplares neste sentido, principalmente o aposento de Titorelli. Da mesma forma, o quarto de Gregor Samsa em $A$ Metamorfose se torna um depósito de tudo aquilo que é descartado pela família, diminuindo cada vez mais o espaço de locomoção do rapaz-inseto.
} 
sempre existir algo fora de lugar, uma aresta que incomoda constantemente o leitor.

É uma obra que certamente prescinde da busca pelo belo, mas que possui uma relação dúbia com o conceito de sublime: nela não há uma ultrapassagem dos sentidos em direção ao ilimitado, ao grandioso, ou uma conciliação entre imaginação, entendimento e razão, mas sim o desacordo das estranhas figuras e ambientes descritos de forma extremamente detalhada e "realista" - e, simultaneamente, é exatamente este detalhamento que torna tais figuras "surreais".

Cada palavra é escrita como se fosse uma inserção cirúrgica e dolorosa no tecido do real e lá permanece. Tal efeito certamente era buscado pelo autor de Praga tanto no que lia como no que produzia.

\begin{abstract}
Acho que só devemos ler a espécie de livros que nos ferem e trespassam. Se o livro que estamos lendo não nos acorda com uma pancada na cabeça, por que o estamos lendo? Porque nos faz felizes, como você escreve? Bom Deus, seríamos felizes precisamente se não tivéssemos livros e a espécie de livros que nos torna felizes é a espécie de livros que escreveríamos se a isso fôssemos obrigados. Mas nós precisamos de livros que nos afetam como um desastre, que nos magoam profundamente, como a morte de alguém a quem amávamos mais do que a nós mesmos, como ser banido para uma floresta longe de todos. Um livro tem que ser como um machado para quebrar o mar de gelo que há dentro de nós. É nisso que eu creio ${ }^{188}$.
\end{abstract}

\footnotetext{
${ }^{188}$ KAFKA, Carta a Oscar Pollak, 1904. A lista de obras e autores que "ferem e trespassam" Kafka inclui, de acordo com a biografia escrita por Max Brod, desde Kleist e Dickens (o qual, apesar de apreciar, Kafka censurava a verborragia) até Thomas Mann (com especial interesse no conto Tonio Kroeger). De acordo com BROD (1995, p. 51), "seu amor por Goethe e Flaubert nunca mudou nos vinte e poucos anos em que fui seu amigo", mesmo não havendo um eco evidente destes autores em sua escrita. Goethe era para Kafka mais do que um modelo de escrita, mas sim "um modelo de vida" (ZILCOSKY, 2003, p.44), o que era um tanto comum entre os jovens da comunidade judaica em Praga, com profunda influência da cultura alemã. Na mesma carta a Pollak, Kafka recrimina o amigo por admirar Goethe sem a profundidade necessária ou sem "seguir seus passos" (ZILCOSKY, idem). No caso de Flaubert, Kafka afirma em alguns momentos ser seu "filho espiritual" (Cartas a Felice, apud ZILCOSKY, p. 45). O timbre de autores russos como Gogol, Kropotkin e, principalmente, Dostoievski - todos encontrados nas estantes kafkianas - é possível de ser sentido em alguns momentos. De acordo com TRAGTEMBERG (2001), o absurdo da existência é fator comum a ambos os autores, seja pela constatação de que toda forma de organização social ou religiosa é erigida sobre a ideia do absurdo e tende à burocracia. Para Tragtemberg, a parábola do Grande Inquisidor, em Os Irmãos Karamazovi, é um
} 
Mas o que provoca esta ruptura desejada por Kafka não está em primeiro plano em sua obra: não é a transformação de Gregor Samsa ${ }^{189}$ em inseto ou a acusação contra Josef $\mathrm{K}^{190}$ que provocam no leitor pavor ou desespero, mas sim algo que parece estar presente na obra sem que esteja realmente escrito ${ }^{191}$. Uma coisa que não aterroriza, mas provoca algo diferente, uma inquietação e um incômodo maior, que parece nunca estar resolvido. "Quando certa manhã Gregor Samsa acordou de sonhos intranquilos ${ }^{192 " ~ e m ~ d i r e c ̧ a ̃ o ~ a ~ s e u ~ d e s t i n o ~ c o m o ~ i n s e t o ~ m o n s t r u o s o, ~ n a ̃ o ~ e ́ ~}$ mais possível - tanto para o personagem como também para os leitores -

exemplo claro disso em Dostoievski: nela, "Cristo desce à terra na época da inquisição espanhola. O Grande Inquisidor justifica sua missão terrena mostrando a Cristo que ele dando liberdade ao homem - "a verdade vos tornará livres" - "eu sou a verdade" - deu-lhe um fardo pesado para suas costas fracas e o Grande Inquisidor "tirando-Ihe a liberdade em troca da segurança" revelou-se seu amigo, ao mesmo tempo em que transferia toda responsabilidade dos atos humanos na terra para si, deixando para o homem o pão terrestre. Em nome do homem e do cristianismo o Grande Inquisidor poderia atirar Cristo à fogueira." (p. 2). Já o absurdo em Kafka estaria na relação do homem consigo mesmo e na incomunicabilidade entre os seres humanos. A similaridade de abordagem sobre a questão da burocracia será alvo de análise posterior. Outro indício da presença do escritor russo no imaginário kafkiano está em uma das obras mais famosas do autor checo: na Carta ao Pai, ao comparar as ameaças do pai com seus "gritos, o enrubescimento do seu rosto" (CP, p. 30) - mas que não se concretizavam em uma surra - ao homem condenado à forca e que só fica sabendo de seu indulto quando "o laço pende diante do seu rosto" (CP, idem), o que pode fazer com que este carregue a culpa por toda a vida. Kafka faz referência direta ao ocorrido com Dostoievski, que só ficou sabendo de seu indulto exatamente nestas condições descritas. A descrição em questão é vista por BACKES (2011) como indicação clara da influência do russo no texto do autor checo. Porém, talvez a maior influência sobre a prosa kafkiana seja a exercida pelo suíço Robert Walser (1878-1956). Os primeiros contos de Kafka foram definidos por MUSIL (apud TELAROLLI, in WALSER, 2011) como "um caso particular do tipo Walser". Tal parentesco foi perpetuado em um sem-número de análises sobre Kafka, com destaque para as de BENJAMIN (p.53), ADORNO (p. 249), Coetzee e Canetti. Musil salienta "a delicadeza paradoxal - superficial e profunda - do tom lúdico e inconsequente de Walser" (ROSENFIELD, 2011) e constrói uma ponte conceitual entre este paradoxo e o rigor na escrita kafkiana, também plena de aporias.

${ }_{189}$ Protagonista de A Metamorfose.

190 Protagonista de O Processo. Cabe uma indagação a ser analisada posteriormente neste trabalho: até que ponto o personagem principal da obra, em vez de ser Josef K., não é o processo em si?

${ }^{191} \mathrm{O}$ uso da linguagem de forma conotativa ou figurada, implicando mais significados do que a interpretação literal do que está escrito, remete-nos diretamente à questão da alegoria como elemento da escrita kafkiana. A alegorização (ou seja qual a figura de linguagem utilizada), como elemento provocador do estranhamento, acaba por estar relacionada à problemática do sublime, se a entendermos como uma tentativa de expressar em palavras algo que é irrepresentável.

${ }^{192}$ M., p. 6 
"acordar" mais uma vez e escapar da situação, notar que tudo era somente mais um sonho.

Inquietação ou estranhamento, conforme definido por Freud ${ }^{193}$, seriam formas de nomear essa sensação que surge da ambivalência entre o extraordinário e o cotidiano. Unheimlich, em alemão, pode significar tanto aquilo que é incomum, não-familiar, como o que é cotidiano, usual. No texto de Freud a palavra designa exatamente aquilo que era familiar e subitamente se torna externo, inexato, inesperado, vindo dessa característica seu poder de choque e deslocamento. Conforme o fundador da psicanálise,

Em geral, somos lembrados de que a palavra 'heimlich' não deixa de ser ambígua, mas pertence a dois conjuntos de ideias que, sem serem contraditórias, ainda assim são muito diferentes: por um lado significa o que é familiar e agradável e, por outro, o que está oculto e se mantém fora da vista. 'Unheimlich' é habitualmente usado (...) apenas como o contrário do primeiro significado de 'heimlich' e não do segundo. (...)'heimlich' é uma palavra cujo significado se desenvolveu na direção da ambivalência, até que finalmente coincide com seu oposto, 'unheimlich'194.

É interessante notar que o conceito freudiano de estranhamento e a definição do sublime por Kant acabam por se mostrar ligados de forma sólida, ainda que indireta. Se para Kant o gosto é algo subjetivo e o belo é aquilo que provoca reações agradáveis por parte de todas as pessoas, trazendo sensações de tranquilidade e conforto, há coisas que provocam reações mais complexas quando contempladas, que trazem fascinação, inquietação e desconforto - ao ponto de serem praticamente indescritíveis.

Kant usa como exemplo do sublime a força da natureza. Em uma tempestade, ouvimos o som do trovão com medo, respeito e um certo alívio por sermos apenas espectadores. Em uma primeira visada, este

\footnotetext{
${ }^{193}$ No texto "O Inquietante" datado de 1919

${ }^{194}$ FREUD, 1976, pp. 282-283
} 
foco do sublime naquilo que é majestoso e ultrapassa a capacidade de compreensão pouco teria a ver com a característica de familiaridade levantada por Freud, assim como não se relacionaria com os ambientes claustrofóbicos descritos por Kafka. Mas o estranhamento, estranhamente, acaba por se aproximar do sublime por um tipo de efeito contrário: não se trata de tentar exprimir aquilo que é inexprimível e grandioso, mas sim de dizer o inominável a partir do banal e do corriqueiro. Esta visão sobre o sublime e o conceito de estranho compartilham um diagnóstico de contraste entre o objeto da contemplação e a reação a este, e não a harmonia entre eles.

O texto de Freud deixa clara esta não-aliança entre aquilo que é chamado por ele de "doutrina das qualidades de nosso modo de sentir ${ }^{195 "}$ e uma "doutrina do belo196", ou seja, um descompasso entre a fruição estética do objeto pelo sentimento do sujeito e a análise não do que sentimos, mas das pulsões que estão ocultas em nossos sentimentos ${ }^{197}$. Há algo que não está contido na beleza ou na capacidade de agradar, mas a nega ou até ultrapassa; esta negatividade fica mais evidente no próprio texto freudiano:

Ora, sobre esse ponto, nada é encontrado, por assim dizer, nas apresentações detalhadas da estética, que preferem em geral se ocupar dos modos de sentimento belos, grandiosos,

\footnotetext{
195 Ibidem, p. 282-283

196 lbidem, p. 282-283

197 Remetendo agora à obra de Kafka, tal descompasso poderia estar presente - ou ser percebido - até mesmo na linguagem utilizada pelo autor de Praga? CARONE (2011) observa que, ao se ater à imagética das figuras de linguagem e levá-las ao pé da letra, Kafka manobra a linguagem de forma a abrir novas possibilidades de sentido e de interpretação tendo como base expressões já esvaziadas pelo uso: "não é sobre a metáfora em si que o escritor se interessa, mas sobre o efeito artístico (e de conhecimento) que faz dela aquilo que é" (EFK, pg.17). A incapacidade ou supercapacidade da linguagem em expressar o que quer ser dito levaria à sensação de vertigem que define o sublime. Aqui, ganha corpo um paralelo entre a ideia da desterritorialização/reterritorialização da linguagem por Deleuze e a negação/hiperconformidade da forma-conteúdo em Adorno - como maneiras de esgarçamento e abertura de novas possibilidades de resistência e contestação no real. A própria obra de Kafka pode ser tomada como exemplo desta relação de resistência: a economia de linguagem opera como uma economia do desejo dentro da obra. Da tensão no uso da língua, que em um primeiro momento restringe o entendimento e depois paradoxalmente o abre, resulta aquilo que provoca a vertigem, o deslocamento. $\mathrm{O}$ sublime como choque e ultrapassamento.
} 
atraentes, ou seja, positivos, assim como de suas condições e objetos que os provocam, mais do que de seus modos opostos, repelentes e penosos ${ }^{198}$.

A ocultação destes "modos negativos das qualidades do sentir ${ }^{199 "}$ angustiantes, opostos, repelentes - é o maior indicativo de sua existência. Por assumir um caráter velado, aquilo que é inquietante não se dá à plenitude do conhecimento, da razão ou do intelecto, sendo irrepresentável ou indescritível. Tal estranhamento remete a uma "experiência de difícil apreensão na esfera do conceito, cuja marca fundadora é mesmo a do paradoxo de uma polaridade, uma ambivalência ${ }^{200 ", ~ q u e ~ e v o c a ~}$

o ânimo sublime, em que os elementos contrários coexistem estranhamente - o prazer e a dor; o fracasso da imaginação e o triunfo da razão; os sentimentos de pequenez, insignificância e morte e a elevação ao incondicionado eivada de reafirmação moral ${ }^{201}$.

Tal coexistência é vista no próprio léxico da obra kafkiana, que contém em si tais aporias e contrastes: a escrita, como a fé e a guilhotina, é "pesada e leve ao mesmo tempo"202 e construída com rigor para "evitar um equívoco verbal: o que deve ser ativamente destruído precisa antes ser sustentado com firmeza total; o que desmorona, desmorona, mas não pode ser destruído."203

Dois exemplos interessantes dessa coexistência dos contrários estão nos trechos a seguir de A Metamorfose e Um Artista da Fome, que se

\footnotetext{
${ }^{198}$ FREUD, in MASSARA, G. p.230

${ }^{199}$ Ibidem, p.230

${ }^{200}$ Ibidem, p.231

201 Ibidem, p. 230

202 Aforismo 87. EFK, p. 203.

${ }^{203}$ Ibidem, Aforismo 91.
} 
passam, coincidentemente, em momentos nos quais o protagonista se encontra às portas da morte ${ }^{204}$.

Logo descobriu que não podia absolutamente mais se mexer. Não se admirou com este fato, pareceu-lhe antes pouco natural que até agora tivesse conseguido se movimentar com aquelas perninhas finas. No restante, sentia-se relativamente confortável. Na realidade tinha dores no corpo todo, mas para ele era como se elas fossem ficar cada vez mais fracas e finalmente desaparecer por completo. A maçã apodrecida nas suas costas e a região inflamada em volta, inteiramente cobertas por uma poeira mole, quase não o incomodavam. Recordava-se da família com emoção e amor. Sua opinião de que precisava desaparecer era, se possível, ainda mais decidida que a da irmã. Permaneceu neste estado de meditação vazia e pacífica até que o relógio da torre bateu a terceira hora da manhã. Ele ainda vivenciou o início do clarear geral do dia do lado de fora da janela. Depois, sem intervenção de sua vontade, a cabeça afundou completamente e das suas ventas fluiu fraco o último fôlego ${ }^{205}$.

Neste trecho o sentimento de amor pela família (uma recordação, algo que ficou no passado) mistura-se à opinião racional de Gregor sobre a necessidade de desaparecer - ou dar a situação por encerrada. O protagonista chega a um estado de transcendência em relação ao que o cerca - puro pensamento - e a redenção se dá "sem intervenção de sua vontade": até a meditação, o pensar, cessa ao final, impotente contra o destino inexorável. Mas a partir do momento em que este destino se cumpre, o alívio é completo - porque sabemos que o drama de Gregor

\footnotetext{
${ }^{204}$ Certamente isto não é uma coincidência. A relação entre morte e sublime também pode ser localizada em Freud. No texto Sobre a transitoriedade (1916), ele enaltece a beleza efêmera como sublime exatamente porque acaba. A dimensão da "morte" do que é belo - e, de acordo com a análise de GUATIMOSIM (2008), esta morte está ligada à ideia de castração e vazio - engrandece a fruição da beleza: "beleza aqui não mais ideal, como queria o melancólico interlocutor de Freud, mas sublime, ou seja, para além do belo ideal imaculado, estático, especular, homo, temos o sublime que transita entre a vida e a morte, marcado pelo tempo, pelo paradoxo humano, pela divisão subjetiva, indicando então a diferença radical, o singular, o héteros" (GUATIMOSIM, p. 51). A visão freudiana ecoa, certamente, em Benjamin e Adorno, e a discussão sobre o efêmero que envolve ambos os filósofos é prova disto, como mostra a frase de Adorno "O efêmero, ao ser perpetuado, é atingido por uma maldição" . (AsK, p. 248)

${ }^{205}$ M., p. 78 / EFK, p. 286
} 
termina assim como tal alívio é visível em sua família, liberta e reconfigurada ${ }^{206}$.

Em uma situação análoga, o artista da fome é tomado como louco ao ser encontrado, e a razão extrema que esgrime em seu argumento para o jejum - a revelação da origem de seu talento - nos mostra que sua maior habilidade, ao final, pesa como um fardo para o qual a morte surge como uma solução.

- Você continua jejuando? - perguntou o inspetor - Afinal quando vai parar?

- Peço desculpas a todos - sussurrou o artista da fome, só o inspetor, que estava com o ouvido colado às grades, 0 entendia.

- Sem dúvida - disse o inspetor, colocando o dedo na testa, para indicar aos funcionários, com isso, o estado mental do jejuador. - Nós o perdoamos.

- Eu sempre quis que vocês admirassem meu jejum - disse o artista da fome.

- Nós admiramos - retrucou o inspetor. - Por que não haveríamos de admirar?

- Mas não deviam admirar - disse o jejuador.

- Bem, então não admiramos - disse o inspetor - Por que é que não devemos admirar?

- Porque eu preciso jejuar, não posso evitá-lo - disse o artista da fome.

- Bem se vê - disse o inspetor. - E por que não pode evitálo?

- Porque eu - disse o jejuador, levantando um pouco a cabecinha e falando dentro da orelha do inspetor com os lábios em ponta, como se fosse um beijo, para que nada se perdesse. - Porque eu não pude encontrar o alimento que me agrada. Se eu o tivesse encontrado, pode acreditar, não teria feito nenhum alarde e me empanturrado como você e todo mundo.

${ }^{206}$ LYOTARD (1997) afirma que, para Burke, o sublime é a composição entre terror (uma paixão mais forte do que a simples satisfação, ligada à privação de algo e a representações associadas inconscientemente a situações dolorosas) e prazer (um prazer negativo, ligado à dor e à morte). Para que esta composição ocorra, a ameaça que desencadeia o terror deve ser "mantida a uma certa distância, retida. Esta incerteza, esta diminuição de uma ameaça provoca uma espécie de prazer que não é, por certo, o de uma satisfação positiva, mas sim de um alívio" (LYOTARD, p. 104). Frente a um risco incomensurável, a alma se imobiliza. "Ao afastar esta ameaça, a arte proporciona um prazer de alívio, de delícia" (idem, ibidem). Nos dois trechos acima, a morte não chega como um castigo, mas como uma libertação. Como alívio sublime, a ser fruído após o fato. Desta forma, faz muito sentido que os contos não terminem simplesmente com a morte de seus protagonistas, indicando uma possível relação entre tal imobilidade da alma e o comportamento mimético. 
Estas foram suas últimas palavras, mas nos seus olhos embaciados persistia a convicção firme, embora não mais orgulhosa, de que continuava jejuando 207 .

Ainda em Um Artista da Fome, o contraste entre a ruína do artista e a jovem pantera que passa a ocupar a jaula chega a ser didático neste sentido, pois o terror e assombro característicos do sublime se deslocam do interior para o exterior da jaula:

Mas na jaula puseram uma jovem pantera. Era um alívio
sensível até para o sentido mais embotado ver aquela fera
dando voltas na jaula tanto tempo vazia. Nada Ihe faltava. O
alimento de que gostava, os vigilantes traziam sem pensar
muito; nem da liberdade ela parecia sentir falta: aquele corpo
nobre, provido até estourar de tudo o que era necessário,
dava a impressão de carregar consigo a própria liberdade; ela
parecia estar escondida em algum lugar das suas mandíbulas.
E a alegria de viver brotava de sua garganta com tamanha
intensidade que para os espectadores não era fácil suportá-la.
Mas eles se dominavam, apinhavam-se em torno da jaula e
não queriam de modo algum sair dali ${ }^{208}$. (grifos nossos)

Baseando-se em Kant, pode-se concluir que a fruição da experiência do sublime não está relacionada diretamente à forma pela qual ela se "manifesta", por ser uma grandeza acima de qualquer possibilidade de medida, replicação ou representação. É de se pensar, então, se é possível dizer que não é a modalidade ou linguagem artística utilizada que provoca em nós este sentimento do sublime; mas podemos supor que a delicada relação entre o que uma obra explicita e aquilo que ela deixa entrever, mas não é capturado por ela, permite uma apreensão fugidia e incompleta daquilo que nos inquieta ao termos contato com a obra ${ }^{209}$. No sublime, a

${ }^{207}$ AF/C, pp. 34-35
${ }^{208}$ AF/C, pp. 35-36
209 É possível pensar em uma digressão sobre o tema a partir do conceito de aura em Walter
Benjamin. Se, para o pensador frankfurtiano, a aura representa o caráter transcendente,
fugidio e inesgotável da obra, inapreensível apesar da proximidade a ela, este paradoxo
entre proximidade e distância não nos leva a uma remissão à ideia de beleza, como a
tradição crítica nos diz, mas ao sublime. Se, de acordo com AVELAR (2008), "a beleza da 
ideia do que é não está ao alcance de sua representação: ela parece estar sempre prestes a ocorrer, mas se mantém ainda a uma certa distância.

Assim, o sublime não estaria no que se mostra, e sim no que se oculta, no irrepresentável e no não-representado. Tal inversão do conceito é efetuada por Kafka se postularmos a ideia de que para ele, partindo daquilo que the é mais familiar, é possível desvelar o que existe de mais estranho ou surpreendente, ou seja, atingir a estranheza típica do sublime a partir do que é menos estranho.

No conto $A$ Construção, a repetição incansável dos passos do roedor para construir e vigiar os túneis de sua toca - envoltos em procedimentos meticulosos e rotineiros que em certos momentos nem ele segue à risca acaba por distrai-lo da ameaça que, em seu pensamento, sempre esteve à espreita. Tal repetição Ihe dá a segurança que julga ameaçada desde sempre. A partir do momento em que o roedor percebe o ruído que rompe o silêncio seguro da toca (um evento do qual não se tem certeza sobre a origem), a segurança desaparece quase que por mágica: "quando cheguei, não o ouvi de modo algum, embora ele decerto já estivesse presente $210 "$.

$\mathrm{Na}$ mente do roedor, a ameaça finalmente está vindo em sua direção. Foi contra esta ameaça que sua vida/obra (a toca) foi voltada mesmo sem o saber: "no entanto, houve algo parecido no início da construção. A principal diferença é que eram os primeiros tempos da obra ${ }^{211 "}$. Agora é visível que todos os procedimentos do roedor, ainda que

obra de arte reside em sua essência misteriosa" e a aura equivaleria a um "véu ou invólucro que exprime o Belo preservando a inacessibilidade da própria essência da Beleza", esta poderia ser entendida como operando em dois níveis: um no qual há a relação com a forma - o hic et nunc desta - e outro no qual esta relação é impossível. Nesta segunda acepção, tal não-coincidência nos colocaria no terreno do sublime, e não no belo.

${ }^{210}$ AF/C, p. 87

${ }^{211}$ AF/C, p. 103. CARONE (2011) considera que A Construção trata das batalhas de Kafka contra a morte (a tuberculose) e o horror (o fascismo) que se desenhavam no horizonte. Eventos contra os quais ele pouco ou nada pôde fazer, apesar da ilusão de segurança que a toca lhe proporciona (a vida regrada e a fortaleza de sua obra). Sem que se percebesse, tanto a doença como o horror se desenvolvem. Perante a inexorabilidade da doença ou a ascensão da opressão, o que um escritor judeu de Praga poderia fazer? DELEUZE ressaltará o caráter político da literatura kafkiana como a voz de seu povo em oposição às identidades majoritárias: a escrita como uma forma de expressão daqueles que não 
banais, sempre foram contaminados pelo signo do medo, por um perigo sempre presente ainda que despercebido. Com sua revelação, manifestase o "estranho" existente nos atos cotidianos do roedor.

Preso em seus pensamentos, o roedor hesita entre ação e imobilidade, buscando as certezas e a proteção perdidas. O silêncio retorna à construção - pois o ruído se torna banal, parte do ambiente. Porém, não mais como sinal de segurança, e sim como a calma que precede a tempestade que paira sobre a cabeça do narrador. A ameaça continua lá, em suspenso ("mas tudo continuou inalterado ${ }^{212 ")}$, levando o conto a um anticlímax pela ausência de desfecho.

No sentimento do sublime também é preciso superar o próprio medo e ir em direção ao desconhecido, ao que é estranho. O grotesco, o inquietante, o desconfortável identifica-se com aquilo que é mais familiar e comum. Mais do que análogo ao sublime, o estranho como efeito em Kafka torna-se idêntico a ele. O conto "O Foguista" retrata de forma bastante visível esta questão.

Uma viagem, ou o movimento de deslocamento de um lugar a outro, é em si uma experiência que mescla o abandono da segurança e o temor, ou fascínio, do desconhecido. O conto tem início com a chegada de Karl Rossmann em um novo território, a América, abandonando seus vínculos familiares e um passado que o embaraça. Podemos inclusive entender a perda de sua bagagem como uma representação simbólica desta ambiguidade entre o desbravamento de um novo território e o desejo de conservação dos objetos que the fornecem referencial de identidade e vínculo familiar, como as camisas e o salame veronês que sua mãe Ihe dera ${ }^{213}$.

conseguem se expressar. Nas palavras do próprio Kafka, "a literatura tem menos a ver com a história literária do que com o povo" (Diários, 25 de dezembro de 1911). Tal caráter político também é ressaltado por CARONE (2011, pp 19-23).

${ }^{212}$ AF/C, p. 108

213 Deleuze estabelece uma relação entre o ato de comer com os conceitos de reterritorialização e desterritorialização, que podem ser aplicados a este conto que trata, ao fim e ao cabo, exatamente do deslocamento do ser em direção ao desconhecido e, ao mesmo tempo, da tentativa do protagonista em recuperar a sensação de segurança. Em $O$ Desaparecido, romance do qual O Foguista faz parte, o alimento dado pela mãe, 
Perdido em caminhos que nunca havia percorrido no navio, Karl acaba por se tornar espectador involuntário do drama do foguista, uma pessoa com sérios problemas de relacionamento com seus colegas da tripulação, principalmente com o romeno Schubal. O foguista simpatiza imediatamente com Karl, o que acontece reciprocamente, e busca o apoio de Rossmann para a resolução de seus problemas.

Assim, o protagonista acaba sendo jogado em uma situação da qual não conhece mais do que o relato que ouviu na cabine de seu atual guia na jornada, do qual acaba por assumir a posição de "advogado de defesa". A solução da situação para Karl ocorre como um deus ex machina com o surgimento do tio, mas o problema do foguista fica sem solução, o que angustia o viajante. $O$ encontro com o tio, se pode trazer uma sensação de alívio a Karl por ser retirado da disputa, novamente o joga dentro do espectro da família, de algo que é conhecido - pelo vínculo familiar e pelo fato do tio saber os motivos pelos quais ele teve que viajar.

Se unheimlich (a inquietante estranheza) significa "tudo o que deveria ter permanecido secreto e oculto mas veio à luz" ${ }^{\prime 214}$, tanto a revelação dos segredos da família Rossmann como a da ameaça ao animal em sua toca provocam esta sensação de inquietude e de desconforto em quem lê, fundamental no enredo e presente inclusive na linguagem empregada na narrativa. A identificação com o leitor não se dá pela similitude das situações, mas sim pela sensação de deslocamento e vertigem que o texto provoca. O estranho é, em certos momentos,

mantenedora da vida, pode simbolizar tanto uma relação edípica (ou re-edípica) e o desejo de retorno ao seio familiar como a percepção de que, mesmo que tente, Karl nunca se livrará completamente de seu passado (quando a mala finalmente é entregue de volta a ele, o cheiro do salame já impregnou todas as roupas e todo o conteúdo da mala - o que é narrado no decorrer do conto). Em ambos os casos, a inadequação entre o momento vivido e o desejado é a marca, e o desconforto em sua própria origem é patente. Tal possibilidade de leitura deste conto acaba por fornecer elementos aproximativos com duas obras de Goethe e Flaubert especialmente apreciadas por Kafka, a saber: Viagem à Itália e Viagem ao Egito, e que direta ou metaforicamente abordam tais experiências de deslocamento e não-pertencimento, mas com uma diferença: enquanto Goethe e principalmente Flaubert buscam na viagem um perder-se no mundo e uma perda de si que acaba por resultar em um encontrar-se consigo mesmo, o perder-se de si seria o objetivo principal do personagem do conto de Kafka (e do autor, por extensão). (ZILCOSKY, p. 50)

${ }^{214}$ SCHELLING apud FREUD, 1976 
idêntico ao familiar, ou mais: é o que é mais familiar que nos deixa mais desconfortáveis, pois permite que se veja além do imediato. Não permite a representação do sublime e assim, paradoxalmente, aponta em sua direção.

\subsection{Desumano e inumano}

É possível traçar uma interessante analogia entre as figuras homemanimal presentes na obra de Franz Kafka e o amortecimento da consciência de si, se buscarmos no autor os sintomas de um processo que atinge seu ápice no presente: a coisificação do homem e as mudanças sociais que a originam - e que decorrem dela.

Adorno, em sua análise sobre o escritor checo, considera que as diversas ocorrências de zoomorfismo em Kafka são uma representação deste descolamento do homem de si mesmo. O indivíduo (ou o sujeito?) se desvanece, substituído por caricaturas, híbridos que mostram a crise na qual a sociedade administrada os coloca. O inseto Gregor Samsa ${ }^{215}$, que por baixo de sua carapaça ainda é irmão e filho, não é mais reconhecido como pertencente ao núcleo familiar.

A hostilidade daqueles com quem mais se identifica exemplifica esta perda de consciência de si e da relação com o outro pois Gregor encontrase imerso em um mundo que caminha para a barbárie. Um mundo que, apesar de parecer um sistema externo ao indivíduo, é fruto das ações de indivíduos que se sentem desconfortáveis na relação com seus semelhantes:

- É preciso que isso vá para fora - exclamou a irmã -, é o único meio, pai. Você simplesmente precisa se livrar do pensamento de que é Gregor.. Nossa verdadeira infelicidade é termos acreditado nisso até agora. Mas como é que pode ser Gregor? Se fosse Gregor, ele teria há muito tempo

${ }^{215} \mathrm{Em} \mathrm{M}$. 
compreendido que o convívio de seres humanos com um bicho assim não é possível e teria ido embora voluntariamente ${ }^{216}$.

O mundo que nos cerca adquire uma aparência monolítica em contraste com o vazio interior, que soa como uma denúncia desta rigidez. O trágico é o fato de Samsa não perder a consciência no processo e sim senti-la se desvanecer aos poucos. Já o macaco Rotpeter em Um Relatório para a Academia apresenta um domínio completo da razão, haja vista que sua humanização é entendida por ele como a única forma para escapar da jaula que o prendia.

Via aqueles homens andando de cima para baixo, sempre os mesmos rostos, os mesmos movimentos, muitas vezes me parecendo que eram apenas um. Aquele homem ou homens andavam pois sem impedimentos. Um alto objetivo começou a clarear na minha mente. Ninguém me prometeu que se eu me tornasse como eles a grade seria levantada. Não se fazem promessas como essa para realizações aparentemente impossíveis. Mas se as realizações são cumpridas, também as promessas aparecem em seguida, exatamente no ponto em que tinham sido inutilmente buscadas. Ora, naqueles homens não havia nada em si mesmos que me atraísse. Se eu fosse um adepto da já referida liberdade, teria com certeza preferido o oceano a essa saída que se me mostrava no turvo olhar daqueles homens. Seja como for, porém, eu os observava desde muito tempo antes que viesse a cogitar nessas coisas - sim, foram as observações acumuladas as que primeiro me impeliram numa direção definida. (...) Era tão fácil imitar as pessoas! ${ }^{217}$ (itálicos nossos)

Mas até que ponto ele não saiu de uma prisão para outra sem perceber, ao submeter sua natureza ao domínio de uma razão que lhe é,

\footnotetext{
${ }^{216} \mathrm{M}, \mathrm{p} .78$

217 UMR, p. 66-67. A relação mimesis-humanização se torna mais clara desta forma.
} 
realmente, externa ${ }^{218}$ ? Adorno dirá que, no lugar da reflexão sobre o homem e suas lembranças, o que temos é

\begin{abstract}
a prova por exemplo de sua desumanização. Sua pressão impõe aos sujeitos uma involução quase biológica, preparando o caminho para as parábolas animais de Kafka. O momento da resposta, aquele a que tudo aponta em Kafka, é aquele no qual os homens se dão conta de que não são eles mesmos, e sim coisas. (...) Kafka antecipou magnificamente o conceito psicanalítico posterior da estranheza ao $\mathrm{Eu}^{219}$.
\end{abstract}

O animal surge como representação, também, do primitivo atrelado à ideia da incomunicabilidade: Samsa inicialmente ainda consegue entabular comunicação com sua família e com seu superior no trabalho, porém a perda da capacidade de linguagem de Gregor (quando o falar se transforma em um rumorejar ou em sons ininteligíveis) encontra similitude com a "confusão universal" ou "babilônica" referida por Adorno em sua análise da linguagem na sociedade: muito se fala, pouco se diz, menos se reflete.

A palavra perde significado e com ela a articulação do raciocínio se enfraquece: de um momento para outro, nossa humanidade (razão) desaparece ou nossa animalidade é sublimada, como nos dois exemplos de Kafka. O desvanecimento da capacidade de comunicação está relacionado à perda da capacidade de entendimento sobre si, pois o simples desenvolvimento da razão não fez o homem superar sua animalidade. A posse de si e da Natureza não liberta o "eu autônomo"; ao contrário, uniformiza-o, negando-o.

Em um sistema no qual não nos reconhecemos como indivíduos, estamos sujeitos ao discurso que perpetua o domínio de uma razão

${ }^{218}$ Para Adorno e Horkheimer, o esclarecimento "tem perseguido sempre o objetivo de livrar os homens do medo e de investi-los na posição de senhores" (DE. p. 19). Entretanto, a negação do natural em nome do racional, ou a repressão do instintivo pelo superego, traz para os autores "o signo de uma calamidade triunfal" (DE. p. 19). O desencantamento do mundo, com a substituição da imaginação pelo saber, pode ser analogamente visto na jornada de Rotpeter neste conto de Kafka.

${ }^{219}$ AsK. p. 251 
voltada a fins, não-reflexiva e não-contestadora, gerando a ilusão de autonomia e esvaziando a possibilidade de resistência: "A subjetividade absoluta é, ao mesmo tempo, desprovida de sujeito"220

O fragmento "O homem e o animal"221 é um exemplo desta antropologia dialética. Se a animalidade é sinônimo de natureza e humanidade o é de razão ou do domínio sobre esta natureza, o confronto do homem com sua animalidade é tido comumente como uma recaída no mítico, uma demonstração de "fraqueza" a ser superada pela racionalidade.

Neste mundo liberado da aparência, no qual os homens depois da perda da reflexão de novo se tornaram os animais mais inteligentes, que subjugam o resto do universo, quando não estão se dilacerando entre si, respeitar o animal não é mais considerado simplesmente como sentimentalismo, mas como uma traição do progresso. ${ }^{222}$

O homem-coisa, fruto da sociedade administrada, soa como um híbrido estranho entre humanidade e animalidade, perdendo ambas no processo. $O$ indivíduo não se sente em casa - ou em si - nem no seu próprio corpo.

Os traços do cãozinho representam ainda, como os saltos desajeitados do corcunda, a natureza mutilada, enquanto a indústria de massa e a cultura de massa já aprenderam a preparar tanto os corpos dos animais de criação quanto os dos homens segundo métodos científicos. As massas uniformizadas estão tão pouco conscientes de sua própria transformação, da qual no entanto participam tão convulsivamente, que não precisam mais de uma exibição simbólica desta transformação. (...) A dominação não precisa mais de imagens luminosas, ela se produz industrialmente e penetra através delas com uma segurança ainda maior nos homens. ${ }^{223}$

\footnotetext{
${ }^{220}$ AsK, p. 259

${ }^{221}$ DE, pp.229-237

222 DE. p. 236

${ }^{223}$ DE. p. 234
} 
Sendo o homem um animal também, o simples rememorar desta constatação - a existência de sua própria condição humana - soa ao mesmo tempo como uma provocação e um deslocamento de perspectiva em relação ao sistema. "Em vez da ideia de dignidade humana, conceito supremo da burguesia, aparece em Kafka a ideia da salutar semelhança do homem com o animal"224. Algo que surge apenas no confronto com o que já é dado - como um negativo fotográfico, que mostra todo seu conteúdo no contraste com a luz. Este negativo é o que precisa ser desvelado pelo pensamento, rompendo a visão unidimensional da realidade.

Adorno vê o projeto do pensamento moderno de uma forma mais positiva em sua origem: "compreender o arcaico em nós e na realidade: esse foi o passo definitivo tomado pelo pensamento ocidental"225 - e não o estabelecimento de uma relação de repressão com aquilo que não pode ser explicado pelo sistema ou domado pelo ego enrijecido. Contudo, segundo Adorno, algo se perdeu no caminho e aquilo que deveria ser entendido foi interditado à compreensão.

Em vez de uma recaída no mítico, Adorno considera que nas histórias animais de Kafka há um movimento de resgate da razão, que surge do confronto com tais híbridos. A forma da obra kafkiana ganha a expressão do humano em uma época na qual este humano regride à animalidade, devido à repetição do sempre-igual resultante, entre outros fatores, da atuação da Indústria Cultural e da perda do poder da linguagem: "Na medida em que são atribuídos significados e teorias humanas a elementos da natureza (...) o espírito se reconhece neles"226. Pois mesmo imerso no animal, o humano irrompe, porém isto não se dá de forma imediata. Quando finalmente essa irrupção acontece, novamente

\footnotetext{
${ }^{224}$ AsK, p. 268

${ }^{225}$ ADORNO, in HULLOT-KENTOR, p.24

${ }^{226}$ AsK, p. 264
} 
é sob o signo do estranho: como exemplo, a dor, o medo e o ferimento em Samsa o humanizam e também acentuam a sua natureza animal.

No seu torpor não pensava em outra maneira de se salvar senão correndo; e tinha quase esquecido que as paredes estavam à sua disposição, embora aqui elas permanecessem obstruídas por móveis cuidadosamente talhados, cheios de recortes e pontas - quando nesse momento alguma coisa, atirada de leve, voou bem ao seu lado e rolou diante dele. Era uma maçã; a segunda passou voando logo em seguida por ele; Gregor ficou paralisado de susto; continuar correndo era inútil, pois o pai tinha decidido bombardeá-lo. Da fruteira em cima do bufê ele havia enchido os bolsos de maçãs e, por enquanto sem mirar direito, as atirava uma a uma. As pequenas maçãs vermelhas rolavam como que eletrizadas pelo chão e batiam umas nas outras. Uma maçã atirada sem força raspou as costas de Gregor mas escorregou sem causar danos. Uma que logo se seguiu, pelo contrário, literalmente penetrou nas costas dele; Gregor quis continuar se arrastando, como se a dor surpreendente e inacreditável pudesse passar com a mudança de lugar; mas ele se sentia como se estivesse pregado no chão e esticou o corpo numa total confusão de todos os sentidos. Com o último olhar ainda viu a porta do seu quarto ser escancarada e a mãe se precipitar de combinação à frente da irmã que gritava; pois a irmã a tinha aliviado das roupas para permitir que ela respirasse com liberdade enquanto estava desacordada; viua correr ao encontro do pai e no caminho caírem ao chão, uma a uma, as saias desapertadas; e viu quando ela, tropeçando nas saias, chegou até o lugar onde o pai estava e, abraçando-o, em completa união com ele - mas nesse momento a vista de Gregor já falhava -, pediu, com as mãos na nuca do pai, que ele poupasse a vida de Gregor ${ }^{227}$.

Reside aí a força das "parábolas" kafkianas: por lidarem com extremos, levam ao choque; por nos colocarem perante o desconforto da animalidade de seus personagens, resgatam nossa própria natureza animal. Por nos lembrarem o familiar, exigem interpretação, mas não aceitam nenhuma.

${ }^{227}$ M, p. 60-61. O pedido da mãe pela vida do filho encontra correspondência na reação hostil de Gregor à retirada do quadro da senhora que usava peles, ou o retrato que lhe lembrava a mãe. 
A mentalidade dita burguesa somente reconhece nos outros tal animalidade. Em relação a si mesmo, este arcaico se tornou tabu. Kafka, por manobrar exemplarmente as distâncias entre leitor e obra, força-nos a um tipo de interação (não contemplação ou apropriação) com a personagem, em uma situação absurda: não nos sentimos sendo Gregor Samsa, mas nos sentimos como insetos.

$\mathrm{Na}$ Metamorfose, o percurso da experiência se deixa reconstruir na literalidade, como extrapolação. "Estes viajantes são como percevejos", diz a expressão que Kafka deve ter escolhido, alfinetando-a como um inseto. O que acontece com um homem que é um percevejo do tamanho de um homem? ?228 $^{228}$

Se imaginarmos o olhar de uma criança que contempla um adulto integrado a uma sociedade baseada na repressão dos instintos, onde a pulsão é direcionada ao trabalho e o pensamento só opera como validação da estrutura (ou sistema) e não como forma de "liberação do ser" - este ser visto pela criança, de pernas enormes e cabeça pequena, não é assim tão distante do percevejo.

Os híbridos indicam também outra característica do estranhamento: a situação de deslocamento ${ }^{229}$. Em Relatório para uma Academia vemos a humanização do macaco que precisa se adaptar ao ser humano. O movimento reverso ocorre em $A$ Metamorfose, com a adaptação do animal

\footnotetext{
${ }^{228}$ AsK, p. 251

229 Utilizando terminologia deleuziana, teríamos um encontro de desterritorializações: homens e animais em terrenos adversos, fora de suas "naturezas". É interessante notarmos que as visões de Deleuze e de Adorno guardam certa consonância sobre o potencial de ruptura e ressignificação do Eu representado nos híbridos. Para Adorno, ao mesmo tempo em que os homens-animais simbolizam a perda da humanidade, apontam para um resgate do instintivo, do id. Em Deleuze, o devir-animal é uma linha de fuga que "não deixa subsistir nada da dualidade de um sujeito da enunciação e de um sujeito de enunciado, mas constitui um único e mesmo processo, um único e mesmo processus que substitui a subjetividade." (K., pp. 54-55). Ou seja, se mostra como uma reconfiguração não apenas do ponto de vista narrativo, como da própria subjetividade. "A essência animal é a saída, a linha de fuga, ainda que no mesmo lugar ou na gaiola. Uma saída, e não a liberdade. Uma linha de fuga viva, e não um ataque" (K., p. 53 - itálicos do autor). A essência do devir-animal não é uma metáfora simples, mas é liberdade e agressão, estados pelos quais os personagens passam.
} 
ao homem, sendo o inseto uma fuga do confronto entre Gregor e sua família - ou o chefe - em uma situação desconfortável, em terreno novo 230 .

Tanto o homem-animal como o animal-homem mostram seres fora de sua zona de conforto e deslocados de sua natureza originária, imersos numa realidade que obriga os personagens à ação, à ruptura do padrão estabelecido ${ }^{231}$. As figuras animais decorrem e são evidência da tensão existente entre duas realidades opostas ${ }^{232}$.

Um elemento presente neste choque de realidades é a própria arte como manifestação humana, mas simultaneamente representação (Darstellung) de um inumano, de um emocional/animal reprimido pela racionalidade esclarecida e pela tessitura social que nos humaniza, isto é, nos aliena dos impulsos primitivos da libido e da desrazão. O cotidiano humano é satirizado por Kafka, ainda no Relatório, quando Rotpeter, o macaco, nos diz que

Se chego em casa tarde da noite, vindo de banquetes, sociedades científicas, reuniões agradáveis, está me

\footnotetext{
${ }^{230}$ Deleuze verá o devir-animal de Gregor não como uma resposta ou ruptura deste com o pai, mas como "encontrar um caminho onde ele não o encontrou" (K., p. 41), como a busca de uma nova possibilidade. O estranhamento como uma linha de fuga, portanto.

${ }^{231}$ Apesar deste potencial de ruptura, a linha de fuga esboçada nos "contos animais" se mostra sem saída, na visão de Deleuze, pois nos remete novamente a uma reinserção da figura do personagem e do drama familiar, o que é visível principalmente em $\mathrm{A}$ Metamorfose. Temos novamente o encontro entre desejo (animal) e estrutura (família), com a reinserção daquele na esfera desta. Como exemplo, Deleuze e Guattari destacam a reação de Samsa frente à foto da senhora usando peles - simbologia da mãe. Exatamente a partir do momento em que Samsa não deixa a irmã retirar a imagem da mãe de seu quarto, Grete começa a se afastar do irmão, deixando de cuidar de sua subsistência até que este definha e morre. Sua reedipianização o leva à morte. No final do conto, o triângulo edípico está refeito - pai, mãe e filha - e a vida de seus componentes segue independentemente do resto do mundo. Assim, o devir-animal "é uma potencialidade dotada de dois polos igualmente reais: um polo propriamente animal e um polo familiar. Vimos, com efeito, que o animal oscila entre seu próprio devir-animal e uma familiarização demasiado humana. (...) todos os animais oscilam entre um Eros esquizo e um Tanatos edípico. Só deste ponto de vista se corre o risco de que a metáfora se reintroduza com todo seu cortejo antropocentrista" (K., p. 67).

${ }^{232}$ Para Deleuze, o devir-animal mostra uma linha de fuga mas não a percorre, pois "o que as tornava capazes de mostrar a saída era outra coisa agindo dentro delas" (K., p. 68). A tensão entre o desvelamento e a ação, assim como entre animal e humano, sugere um processo dialético em curso, mas que em vez de propor uma síntese totalizante como resultado, aponta a suspensão da possibilidade de tal síntese entre eles.
} 
esperando uma pequena chimpanzé semiamestrada e eu me permito passar bem com ela à maneira dos macacos. Durante o dia não quero vê-la; pois ela tem no olhar a loucura do perturbado animal amestrado; isso só eu reconheço e não consigo suportá-10 233

Em A Metamorfose, quando Gregor busca ouvir a peça de violino que Grete executa para os inquilinos, percebe-se um lampejo da humanidade perdida pelo protagonista inseto. Já no Relatório, ao remeter ao teatro (gesto) para criar sua personagem humana e assim convencer a todos, Rotpeter tem como destino o teatro de variedades, onde pode encenar sua humanidade social no mundo do trabalho - no lar, ele se permite certa inumanidade, mas controlada.

Em síntese: o inumano - a arte, a sensibilidade, a libido ${ }^{234}$ - é aquilo que recupera o ser de sua desumanização.

\footnotetext{
${ }^{233}$ EFK, p. 123

${ }^{234}$ Cf. LYOTARD (2001). Já DELEUZE analisa a questão da libido em Kafka como ligada a seus relacionamentos pessoais, e a literatura como uma espécie de operação do autor no tecido da realidade que permite o afloramento de seus desejos/vontade. Desta forma, cada modalidade de escrita (carta, conto, romance) opera uma função neste mecanismo, chamando especial atenção o papel das cartas, vistas como uma forma de lidar com a dificuldade de relacionamento com o feminino e com os relacionamentos amorosos: "Substituir o amor por uma carta de amor, desterritorializar o amor, substituir o "contrato conjugal tão temido, por um pacto diabólico'” (K., p. 46) que mantém o perigo do casamento à distância e permite às intensidades eróticas aflorarem. Deleuze sugere um caráter vampiresco nas cartas de Kafka a Felícia, e essa relação com o vampiro não é gratuita, se levarmos em conta a intensa significação erótica na imagem de Drácula e no sangue como símbolo de força e energia vitais. O vampiro, especialmente, parece uma figura fascinante no processo. Deleuze aponta a existência de um ensaio de Claire Parnet, o qual não foi possível localizar, em que a relação Kafka-Drácula seria aprofundada. Seria o vampiro um tipo novo de devir-animal, que não reproduz a ideia molar/majoritária que temos dessas criaturas como seres das trevas e encarnação do mal, mas sugere, pelo beber sangue, uma potência de vida que irrompe e flui entre os indivíduos? Ou Drácula e seus amigos seriam o contraponto - e por isso mesmo a resposta e a liberação - ao sujeito domado/dominado/domesticado pela Razão e enredado nos modelos majoritários de bem, moral, segurança, etc.? Se o vampiro (assim como outros monstros) é a personificação de muitos dos medos e desejos humanos, abre-se a intrigante possibilidade da relação medodesejo ser motor e ferramenta de libertação do "majoritário" por meio da transgressão, do desejo de transgredir.
} 


\subsection{Duplos e séries}

O inumano em Kafka não é representado apenas pela natureza animal. Os movimentos repetidos, as máquinas fantásticas e as figuras duplicadas ${ }^{235}$ são exemplos do "princípio hermético" do texto de Kafka, a "subjetividade completamente alienada236" - ou, em outras palavras, do afastamento e alienação extremos na relação do sujeito consigo mesmo e com o semelhante. "O que está contido na bola de vidro kafkiana é mais coerente e portanto mais cruel ainda do que o sistema lá fora porque no espaço e no tempo absolutamente subjetivos não há lugar para algo que possa perturbar seu princípio, o da alienação inexorável ${ }^{237 " . ~ A l i e n a c ̧ a ̃ o ~ d e ~}$ si - ou enxergarmos a nós mesmos como um outro, não nos reconhecendo no mundo que nos cerca - ou a alienação em relação ao outro, que é objetificado e indiferenciado.

Kafka leva ao reconhecimento da nossa própria condição desumanizada - e simultaneamente nossa condição humana - ao mostrar

${ }^{235}$ A recorrência dessas figuras é flagrante em obras como O Castelo, A Preocupação do Pai de Família, Na Colônia Penal, entre outras. Para Deleuze, o próprio texto de Kafka tem tais características maquínicas, devendo ser "desmontado" para seu entendimento. Aqui, a máquina não significa perda de humanidade, mas sim o encontro de linhas de força, de eventos, que compõe o objeto a ser analisado, em uma relação de vizinhança entre termos heterogêneos independentes. A máquina está e é o entorno, não está subsumida ao maquinista. Cada relação de forças é, em si, uma máquina, ou um agenciamento maquínico diferente. A máquina é um "algo" social, é a própria sociedade. E é o mesmo para o organismo: da mesma forma que a mecânica supõe uma máquina social, o organismo supõe, por seu turno, um corpo sem órgãos, definido pelas suas linhas, seus eixos e suas graduações, todo um funcionamento maquínico distinto tanto das funções orgânicas quanto das relações mecânicas. De acordo com esta análise, uma máquina nunca é só técnica, pois sempre faz parte de uma máquina social que usa os homens como peças para seu funcionamento. A aproximação entre a visão da máquina como representação do alienado, e do maquínico como agenciamento de forças individuais e sociais é decorrente da observação dos efeitos destas linhas de força sobre sua resultante, no caso o indivíduo e o corpo social. O corpo sem órgãos, o desejo, é reprimido ou liberado, age nas linhas de força ou sofre a ação delas. O desmontar do maquinismo do texto em Kafka equivale a entender a relação entre autor e realidade que o cerca, como este expressou via linguagem - e a própria linguagem assume uma função neste maquinismo, como um tensor no qual percebemos tais linhas e que as tensiona também. Isso proporciona uma aproximação com a relação entre tecido social e obra de arte conforme pensada por Adorno. O duplo, por sua vez, opera como um espelho e simboliza não apenas uma repetição de signos ou imagens, mas uma diferença entre eles, que se dá no terreno do estranhamento.

${ }^{236}$ AsK, p.258

${ }^{237}$ AsK, p.259. 
personagens cujo relacionamento se dá de forma conflituosa, mesmo sob uma aparente cordialidade. Isso se torna mais visível, como exemplo, nos problemas entre os protagonistas e os personagens femininos das obras (Leni em $O$ Processo, Grete em $A$ Metamorfose $^{238}$, Frieda ou Pepi em $O$ Castelo) ou na relação conflituosa e ao mesmo tempo exagerada descrita na Carta ao Pai - relações marcadas pelo signo da incompreensibilidade.

Este problema no reconhecimento de si e do outro guarda paralelos com o conceito de idiossincrasia, tomado por Adorno como a repulsa irracional em relação ao estranho, o diferente ${ }^{239}$. Mas "o que repele pela sua estranheza é, na verdade, familiar ${ }^{240 " .}$

Esta dupla condição expressa uma relação de amor e ódio, "uma situação em que movimento, ação, e paralisia, inação, se determinam mutuamente e ameaçam conduzir o sujeito diretamente à loucura ${ }^{241 "}$. O conceito psicanalítico do duplo vínculo, usado para definir relacionamentos contraditórios nos quais ocorrem de forma simultânea comportamentos de afeto e agressividade, pode ser visto, como já mencionado, em $O$ Veredicto. E as relações pessoais e sociais dispostas na obra muitas vezes apresentam essa multiplicidade de comportamento. É nesse sentido que

\footnotetext{
${ }^{238}$ Por que razão Grete chora no aposento da esquerda, antes mesmo de saber em que o irmão havia se tornado? O relacionamento em questão é algo mais profundo ou estranho do que parece?

239 Nos Elementos do Antissemitismo (DE, p. 157-194), a idiossincrasia ganha um significado muito além do dicionarismo: em vez de ser o "detalhe de conduta peculiar a um indivíduo determinado e que não pode ser atribuído a processos psicológicos gerais, bem conhecidos" (Dicionário MICHAELIS) - ou seja, a reação personalizada a fatores externos -, idiossincrasia passa a ser entendida como a intolerância completa (seja incompreensão, inamistosidade ou repulsa) a tudo que é diferente de si. Os conceitos de idiossincrasia e mímesis se articulam estranhamente. Neste texto, segundo GAGNEBIN (1993), "Adorno e Horkheimer partem da justificativa tão frequente dos antissemitas: a idiossincrasia, isto é, uma repulsão incontrolável e incontrolada em relação a algo exterior, no caso os judeus. Essa justificativa recusa de antemão questionamentos críticos, pois apela para uma reação fisiológica, pretensamente natural, como de alguém que sofre de alergia à poeira ou ao pêlo dos gatos. Nessa falsa naturalização jaz, no entanto, um elemento de verdade, a saber, a lembrança recalcada de reações miméticas originárias, esses "momentos da proto-história biológica", esses "sinais de perigo cujo ruído fazia os cabelos se eriçarem e o coração cessar de bater". Tais reações, independentes do controle consciente, são uma forma física primeira de mímesis". (GAGNEBIN, p. 75)

${ }^{240}$ DE, p. 170

${ }^{241}$ LAGES, p. 110
} 
para Adorno "os herméticos protocolos de Kafka contêm a gênese social da esquizofrenia" ${ }^{242}$.

A duplicidade pode ser lida também como ambivalência. $O$ uso do duplo (ou das figuras indiferenciadas ou similares) na literatura não é novo, mas funciona como um interessante elemento narrativo: "O tema dos gêmeos indiferenciáveis (...) ou dos simillimi (...) ou dos sósias (...) ou dos duplos (...) tem sido, para a dramaturgia, um filão inesgotável desde a Antiguidade $(\ldots) .{ }^{243 "}$, haja visto que "os equívocos, trágicos ou cômicos, que podem advir de duas personagens ao mesmo tempo diferentes e iguais ${ }^{244 "}$ são um recurso eficaz tanto na comédia como na tragédia.

A perda de sentido do "humano" que surge como consequência dessa duplicidade causa estranhamento, riso ou drama. Em O Castelo, é possível perceber tanto o potencial cômico como o trágico da duplicidade:

Os três então ficaram sentados relativamente em silêncio no salão do albergue, bebendo cerveja numa pequena mesa, K. no meio, à direita e à esquerda os ajudantes. Além desta, só uma mesa estava ocupada por camponeses, de maneira semelhante à noite anterior.

- Com vocês não é fácil - disse K., comparando os seus rostos, como já o tinha feito várias vezes. - Como é que posso distinguir um do outro? Vocês são diferentes apenas no nome, no mais são parecidos como - estacou e depois prosseguiu involuntariamente - no mais vocês são parecidos como cobras.

Eles sorriram.

- Outras pessoas nos distinguem bem - disseram como justificativa.

- Acredito - disse K. - Eu mesmo fui testemunha disso, mas só posso ver com os meus olhos, e com eles não consigo distinguir um do outro. Por isso vou tratá-los como sendo um único homem e chamar os dois de Artur, não é assim que um de vocês se chama... você, por acaso? perguntou K. a um deles.

- Não - disse este. - Eu me chamo Jeremias.

- Bem, dá no mesmo - disse K. - Vou chamar a ambos de Artur. Se eu mandar Artur para alguma parte, vão os dois; se eu der uma tarefa a Artur, vocês dois a fazem;

\footnotetext{
${ }^{242}$ AsK, p. 251

243 FONSECA, p. 10

${ }^{244}$ FONSECA, p. 11
} 
para mim isso tem a grande desvantagem de que não posso usá-los para trabalhos isolados, mas tem também a vantagem de que os dois assumem juntos a responsabilidade de tudo aquilo de que eu os incumbir. Para mim é indiferente de que modo vocês dividem entre si o trabalho, a única coisa que não podem é se desculpar um por causa do outro, para mim vocês são um único homem.

Eles refletiram e disseram:

- Isso seria bem desagradável para nós.

- Como poderia deixar de ser? - atalhou K. Naturalmente que deve ser desagradável, mas é assim que vai ficar ${ }^{245}$.

Vendo a si mesmo como um outro - e vendo o outro como algo indiferenciado - o homem retratado por Kafka é tanto uma representação de figuras do universo do grotesco como uma antecipação de algo mais tenebroso, "homens fabricados em linhas de produção, exemplares reproduzidos mecanicamente semelhantes aos ípsilons de Huxley ${ }^{246 ":}$ o indivíduo fruto da indústria cultural e da ideologia da sociedade administrada.

Tomando essa concepção de Adorno como aplicável a toda a obra de Kafka, esse ambiente repetitivo se mostraria visível em diversos momentos das novelas e contos: se Adorno detecta que o homem padece da ilusão da subjetividade em uma estrutura com todos os dados já condicionados previamente, analogamente, em O Processo, Kafka descreve a confiança ilusória de Josef $\mathrm{K}$, que acredita dominar a situação quando na verdade o processo corre à sua revelia. Se em $A$ Metamorfose Grete acaba por se enfastiar da tarefa que assumiu (por sua própria vontade) de cuidar do irmão-inseto e deseja o fim deste tormento, a análise adorniana sobre a relação do ser com o binômio trabalho-tempo na sociedade administrada mostra que a reprodução dos processos do tempo de trabalho ocorre inclusive no tempo em que não se está trabalhando, de tal modo que o trabalhador não deseja o fim deste processo, pois não consegue perceber a real diferença entre um estado e

\footnotetext{
${ }^{245}$ C, p. 22

${ }^{246}$ AsK, p. 249
} 
outro. $O$ executor do trabalho parece assumir por sua própria vontade o aumento de eficiência, produtividade e mais-valia em benefício do empregador ${ }^{247}$.

Mas talvez o momento onde esta rotina seja mais visível esteja em Na Colônia Penal, onde o suicídio/execução do oficial é literalmente uma relação simbiótica entre o homem e a máquina ${ }^{248}$ : o fato de o oficial programar a máquina de tortura para executá-lo impiedosamente leva ambos à perfeição e à destruição simultaneamente. A simples existência da máquina funcionava como forma de coerção e controle do meio social. Temor e conformidade se misturam transformando o próprio dia-a-dia em condenação. Nas palavras do carcereiro do conto, "seria inútil anunciá-la [a sentença]. Ele vai experimentá-la na própria carne"249. A dualidade e a assincronia na própria noção de si do indivíduo não podem ser lidas sem a relação direta com o ambiente que as gera ou alimenta. O mundo que promove o super-eu é o que destrói a identidade e promove a indiferença ${ }^{250}$.

${ }^{247}$ Deleuze fará uma observação no mesmo sentido em seu texto Post-scriptum sobre as sociedades de controle, apontando que dentre as modificações no tecido social ocorridas desde o colapso das sociedades disciplinares não é das menores o surgimento de uma nova conformação nas relações sociais e de trabalho, cada vez mais semelhantes. $O$ conceito de classes é minimizado e o empregado se vê como um co-laborador, ou alguém que trabalha junto ao chefe. No mundo do trabalho de hoje, diria o autor, "só há gerentes". Isso nos aproxima da leitura adorniana de que a mercadoria assumiu o papel de cultura na sociedade, isto é, as relações humanas passam a ser mediadas pelos códigos da empresa e da mercadoria.

${ }^{248}$ Compreensível tanto pela chave conceitual do fetichismo tecnológico como pela ideia do maquinismo. Entender e conservar o processo de funcionamento da máquina é o que dá sentido à vida do oficial, ao ponto dele ser o único que ainda se importa com aquilo que a máquina executa e representa. Não apenas a relação com a máquina ultrapassa a distância sujeito-objeto (a máquina simboliza/significa um mundo que não retornará mais e que só possui sentido para o oficial) como assume um caráter concreto, uma soma de partes que é mais do que seu todo. Deter o entendimento sobre o funcionamento da máquina pode ser, analogamente, ter a compreensão de como o mundo se inscreve no indivíduo (o que nos aproxima da visão marxiana sobre a determinação da natureza humana por meio das condições materiais - a máquina - da existência). Manter o funcionamento da máquina equivaleria, analogamente, à manutenção de um status quo e de tais processos de inscrição do "mundo" no "sujeito", o transformando/alienando de si - com a máquina sendo o centro de sua vida - e criando um tipo de simbiose homem-máquina na qual decompor o mecanismo da máquina sugere a decomposição do próprio oficial, ou do humano.

${ }^{249}$ NCP. p. 40

${ }^{250}$ Segundo Zischler, um filme que causou grande impacto sobre Kafka foi O Outro (Der Andere, direção Max Mack, 1913) , com Albert Bassermann no papel de um homem que 
Segundo GAGNEBIN, esta indiferença se mostra inclusive na personagem do viajante, que, pretensamente imbuído de uma visão mais "europeia" das coisas e da justiça, apenas contempla o que ocorre sem sequer esboçar algum tipo de intervenção - afinal, como "mais evoluído culturalmente", deve respeitar os estranhos processos como detalhes pitorescos da região que visita: "É sempre problemático intervir com determinação em assuntos estrangeiros ${ }^{251 " . ~ M e s m o ~ c o n s i d e r a n d o ~ a ~}$ máquina um processo desumano, nada faz para mudar o desenlace dos fatos e deixa a ilha sozinho no fim, obrigando o condenado e o soldado a permanecerem naquilo que considera ser uma barbárie. Uma descrição do homem de hoje, no qual o respeito ao que lhe é diferente e ao espaço do outro camufla uma completa indiferença - mais ainda, um desejo confesso de não-intervenção, denunciado também no microconto "Os que passam por nós correndo":

Quando se vai passear à noite por uma rua e um homem já visível de longe - pois a rua sobe à nossa frente e faz lua cheia - corre em nossa direção, nós não vamos agarrá-lo mesmo que ele seja fraco e esfarrapado, mesmo que alguém

desenvolve dupla personalidade após um acidente, um evento mundano. É considerado por ELSAESSER (1996) como o primeiro "filme de autor" alemão, assim como também o primeiro drama psicanalítico do cinema que tratava da dupla personalidade e que já flertava com elementos do cinema fantástico. O Estudante de Praga, do mesmo ano, que também foi assistido por Kafka, lida com a temática do doppelgänger (a réplica andante), símbolo do lado negativo de uma pessoa e sinal de morte iminente, de acordo com as lendas a respeito desta criatura. Neste filme, a criatura negativa triunfa, levando o protagonista Balduin à morte. Metaforicamente, podemos ver isto como um triunfo do lado negativo do ser, mas que, em vez de estar em um espelho ou personificado em uma criatura externa ao protagonista, residiria dentro dele mesmo. As técnicas de filmagem usadas à época (sobreposição de película) permitiam que o ator contracenasse consigo mesmo. Seria possível teorizar que os protagonistas em Kafka realizam o mesmo processo de "atuação", dentro da própria estrutura narrativa? A estrutura de composição de personagens em Kafka parece nos apontar que a esfericidade de um personagem se dá por um choque de naturezas contrárias. Um personagem encerra a si próprio e seu duplo. Um exemplo é Grete, que contém em si tanto a irmã amorosa, substituta da mãe, como a que diz aos pais para abandonarem o pensamento de que o inseto é Gregor (M.,p.78). Sendo o doppelgänger, no folclore da região, também uma espécie de consciência do ser, negativa ou positiva, poderíamos imaginá-lo como sendo o narrador não-onisciente kafkiano? DELEUZE sinaliza que "Em suas cartas, Kafka se serve do duplo, mas seu objetivo é apenas confundir a pista para que troquem seus papéis. Nas novelas, em cada um de seus personagens, Kafka prolifera sobre si sem ter necessidade de se desdobrar nem de passar por duplos" (K., p. 123)

${ }^{251}$ NCP, p.51 
corra atrás dele gritando, mas vamos deixar que continue correndo.

Pois é noite e não podemos fazer nada se a rua se eleva à nossa frente na lua cheia e além disso talvez esses dois tenham organizado a perseguição para se divertir; talvez ambos persigam um terceiro, talvez o primeiro seja perseguido inocentemente, talvez o segundo queira matar e nós nos tornássemos cúmplices do crime, talvez os dois não saibam nada um do outro e cada um só corra por conta própria para sua cama, talvez sejam sonâmbulos, talvez o primeiro esteja armado.

E finalmente - não temos o direito de estar cansados, não bebemos tanto vinho? Estamos contentes por não ver mais nem o segundo homem ${ }^{252}$.

\subsection{0 estranhamento de si}

Se o problema da relação com o semelhante perpassa diversos momentos da obra de Kafka, há quem diga que a própria questão do sujeito é uma das linhas de força de sua produção. Kafka mostraria a falência do modelo de identidade caracterizado pelo sujeito autônomo, senhor de si e dominador da natureza ${ }^{253}$, tanto nas narrativas protagonizadas por animais como no fato de que não temos em sua obra

\footnotetext{
${ }^{252}$ C/F, p. 27

${ }^{253}$ CANEVACCI (1985) realiza uma interessante distinção entre os conceitos de Indivíduo e Sujeito: o primeiro acabou por se referir à esfera psicológico-sensorial humana enquanto o segundo tornou-se uma "qualidade humana que funda as grandes categorias" (p.11), sejam estas transcendentais, sociais ou epistemológicas. Esta cisão, originária da própria organização da sociedade e da separação do homem em relação à natureza, é sistematizada radicalmente na era burguesa, onde o indivíduo se torna a representação daquilo que é "miseravelmente materialista e passional" e o sujeito, o livre-proprietário que transcende tal miséria e é pura categoria ética, lógica, econômica e política. Assim, a posse e o poder deste Sujeito se legitimam e ganham um status quase religioso. Já os sem-sujeito (grupos e pessoas marginalizados durante a história da humanidade: mulheres, escravos, crianças, trabalhadores, etc.) são os que não detêm tal poder ou propriedade das relações sociais de produção. Se o humano, sujeito de si, domina o trabalho, o tempo e a natureza (enquanto o animal é dominado pelo tempo), a perda da condição de sujeito é imanente ao surgimento do que chamamos de sociedade administrada (onde se assiste a um processo reverso de dominação do humano pelo tempo e pelo trabalho)? O homem-animal kafkiano é o ser que surge pelo desenvolvimento das técnicas que subordinam a vida ao imperativo da economia do tempo e da maximização da produção e, simultaneamente, à percepção de perenidade/imobilidade do tempo na estrutura burocrática e, por extensão, nas relações sociais? A cisão do indivíduo se daria, assim, no espaço que ocupa (fábrica, cidade, etc.), nos papéis sociais e também na percepção do fluxo de sua própria vida.
} 
protagonistas que determinam ou influenciam diretamente os fatos descritos na narrativa: eles são levados às situações por forças irresistíveis, as quais muitas vezes desconhecem ${ }^{254}$.

Como os inocentes de Sade - e também dos filmes de terror americanos e dos desenhos animados -, o sujeito kafkiano, especialmente o emigrante Karl Rossmann, pula de uma situação desesperadora e sem saída para outra: as estações da aventura épica transformam-se em uma história de sofrimento. $\mathrm{O}$ nexo imanente se concretiza como uma fuga de prisões ${ }^{255}$.

O trabalho será o definidor da personalidade de cada personagem ${ }^{256}$. Pessoas são descritas como funções ${ }^{257}$ : o gerente, o carcereiro, o agrimensor, o lavrador. Os personagens de Kafka ou são os representantes da máquina burocrática ou são os excluídos da vida social e do alto escalão. São aqueles que arrumam as casas, limpam o lixo, atendem as mesas e as estalagens, levam produtos de porta em porta. Não é uma literatura de grandes heróis, mas de pessoas comuns em situações incomuns (ou situações que, ao serem descritas, parecem incomuns, mas são mais corriqueiras do que se imagina). De certa forma, estão à margem da sociedade - ou sobrevivem nos espaços que ela deixa.

Um exemplo disso é o pintor chamado de Titorelli ${ }^{258}$ : sua existência, basicamente, está voltada à produção de quadros exatamente iguais e ele não tem, na verdade, a ascendência que se espera que tenha sobre os promotores e juízes. Mas isso não o impede de executar sua tarefa e aconselhar Josef $\mathrm{K}$. sobre os rumos que deve tomar - e com isso vender três de seus quadros absolutamente iguais. O fato de mesmo no quarto de Titorelli existirem atalhos para as salas da Justiça pode ser entendido

\footnotetext{
${ }^{254}$ Afinal de contas, quem acusa Josef K? E do que ele é acusado, afinal?

${ }^{255}$ AsK, p. 263

${ }^{256}$ Cf. ANDERS, 2007, p. 67

257 ibid., p. 62

258 "Sei do seu processo através de um certo Titorelli. É um pintor, Titorelli é apenas o nome artístico dele, nem mesmo conheço seu nome real. Já faz anos, de tempos em tempos, vem ao meu escritório". P, p. 127
} 
como uma analogia ao fato de que todos estão, de uma forma ou outra, integrados ao sistema, que permeia todas as instâncias da vida dos indivíduos. Vivem conforme a sociedade e apesar dela. A "identidade" do indivíduo não surge do confronto com o sistema, mas sim da sua adaptação a ele. A identidade vira identificação.

Se os personagens possuem vínculos com o mundo que os cerca, o autor se sente "sem antepassados, sem mulher, sem posteridade, com um violento desejo de possuir antepassados, vida conjugal e posteridade ${ }^{259 " . ~ A ~ s o l i d a ̃ o ~ e ~ d i f i c u l d a d e ~ d e ~ r e l a c i o n a m e n t o ~ g a n h a m ~ t a n t o ~}$ espaço nas interpretações de Kafka por terem se tornado, no nosso século, um problema social ${ }^{260}$. Em um mundo feito de pessoas isoladas, a prosa kafkiana desvela a existência do outro exatamente por sua ausência - pela necessidade de buscar algo que não está ali.

E, quando se observa com maior rigor, Kafka encontra dentro dele mesmo, encravada em sua subjetividade isolada, a presença do social, a dimensão coletiva do humano: "A unidade humana, que todo homem, mesmo o mais social e mais flexível, põe em dúvida de tempos em tempos (ainda que apenas afetivamente) revela-se também, por outro lado, a todo homem - ou parece revelar-se - na harmonia total que pode sempre ser encontrada entre o desenvolvimento do conjunto da humanidade e o desenvolvimento do indivíduo. Mesmo nos sentimentos mais fechados do indivíduo". (Diário, 4-12-1913). ${ }^{261}$

Desta forma, a questão do sujeito se mostra em aberto dentro da obra de Kafka. Um problema fulcral, pois seus textos indicam, mesmo indiretamente, a insuficiência do modelo de um Eu autônomo capaz de deixar sua menoridade - conforme o conceito iluminista. Recorrendo à leitura de Adorno e Horkheimer, tal modelo de sujeito parece resultar exatamente no contrário do que o conceito de emancipação abriga, invertendo-se em repressão de si e dominação dos demais. Isto ocorre

\footnotetext{
${ }^{259}$ Diário, 21 de janeiro de 1922

260 Segundo a análise de KONDER, 1974. p. 107

${ }^{261}$ Ibidem, p. 104
} 
pelo fato da razão ter sido colocada na posição que antes era ocupada pelo sujeito autônomo: a coordenação das instâncias da vida. A instrumentalização da razão e a que foi operada por esta no entendimento da realidade, aparentemente com o objetivo de dar ao ser a capacidade de usar os meios para operar e alterar este real, guarda em si seu contrário, promovendo a liquidação do sujeito por meio de uma subjetivação da realidade ${ }^{262}$.

O processo de subjetivação afeta todas as categorias filosóficas, porém em vez de as reorganizar em uma unidade de pensamento melhor estruturada, as simplificou à posição de fatos a serem catalogados. A própria categoria de Sujeito sofre deste processo, mesmo não podendo mais ser interpretada de forma rígida. É necessário pensar como isso ocorre no mundo e que tipo de mundo dá a base para que isto ocorra.

Buscar saber, de outra forma, "o que acontece com a experiência do mundo quando o fundamento da experiência é um sujeito pensado ${ }^{263 ",}$ mas não realizado, a partir das experiências de unidade, autonomia, transparência e identidade? Conforme Safatle, "a maneira com que compreendemos a categoria de sujeito não poderia deixar de ter consequências na maneira com que definimos o que é um objeto da experiência, quais as condições para que algo aceda à condição de objeto. (...) "264. Assim, "o processo de constituição do Eu moderno, com suas exigências de auto-identidade imediata e de autodeterminação, significou a submissão de toda experiência possível ao primado da identidade e da abstração ${ }^{265 " \prime}$.

262 Se, como algumas correntes filosóficas argumentam, o Sujeito está "morto" e as estruturas/experiências moldam o indivíduo, sendo a vida um aglomerado de substâncias heterogêneas, a exaltação de uma individualidade liberta das garras da mônada liberal que o reduziria a uma figura sem rosto e sem personalidade (o Eu cartesiano-kantiano), paradoxalmente retira tal individualidade deste indivíduo, pois o primado da experiência se sobrepõe ao ser que a frui. O ser se torna objeto da experiência, que é o objeto para sua definição como ser. A subjetivação se transforma na objetivação do ser.

${ }^{263}$ Cf. SAFATLE (2009, p.7)

264 ibidem

265 ibidem. 
Para Horkheimer, tais indivíduos seriam como projeções do que é chamado de "mentalidade do engenheiro", uma forma de pensamento ligada às exigências da produção em si mais do que à busca do lucro e que comanda os homens à posição de "instrumentos sem objetivos

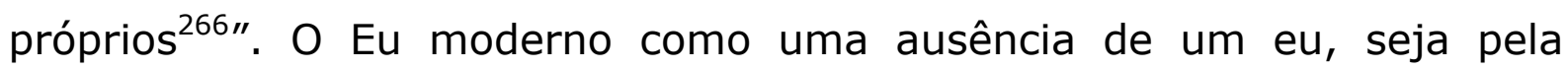
submissão da experiência pessoal à identidade/identificação de massa como da formação da identidade pessoal de acordo com o primado da experiência e do processo social.

Tal situação colocaria o ser humano frente ao que se pode chamar de crise do indivíduo, pois o antagonismo em relação à sociedade, mediante o qual o indivíduo constrói o seu self como projeto, foi substituído na sociedade de consumo por um desejo de adaptação mimética à realidade, seja no ajuste a algo já dado como na ilusão de que a realidade se ajusta a seus desejos. A mediação do poder social pelo poder sobre as coisas implica o domínio do próprio indivíduo pelas coisas, a perda de traços individuais genuínos, a perda de liberdade e a transformação da sua mente num autômato da razão formalizada.

A rigidez de personagens como o oficial em Na Colônia Penal e o pai de Gregor em $A$ Metamorfose remetem à negação adorniana da mímesis, uma característica do pensamento racional na qual "se vinculam a degradação do pensar por imagens e a crítica da força cognitiva da

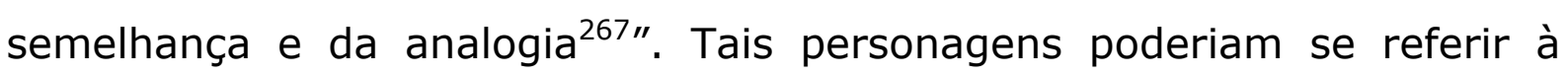
situação do homem moderno, que tem como seu código definidor a negação do seu semelhante, a

identidade do eu que não pode perder-se na identificação com um outro, mas [que] toma possessão de si de uma vez por todas como máscara impenetrável ${ }^{\prime 268}$. Pois a identidade do Eu seria dependente da entificação de um sistema fixo de identidades e diferenças categoriais. ${ }^{269}$

\footnotetext{
${ }^{266}$ HORKHEIMER, p. 156

${ }^{267}$ SAFATLE, 2009, p.6.

${ }^{268}$ DE, p. 24 in SAFATLE. op. cit., p.6

${ }^{269}$ SAFATLE, 2009, loc.cit.
} 
Esta esquematização se mostra nas esferas do pensamento, cultura/arte, sociedade/política e na própria determinação do sujeito. A eliminação da dialética entre indivíduo e sociedade significa a perda da própria noção de si. As categorias de sujeito transcendental, universal e trans-histórico, cristalizadas na expressão kantiana "eu penso", seriam bloqueios ao real entendimento da razão, do sujeito e do social pois estas categorias se projetam sobre o mundo, padronizando a forma de pensar. Isto é chamado, por Adorno, de

falsa projeção ligada à dinâmica do narcisismo e aos processos de categorização do sujeito cognoscente ${ }^{270}$, já que, em última instância, a categorização seria uma projeção do princípio de identidade do Eu na síntese do diverso da intuição em representações de objetos da experiência. ${ }^{271}$

Talvez seja possível ver em um pequeno conto como "A Coleira" tal engessamento da subjetividade, assim como uma manifestação da angústia que surge do confronto entre o externo e o individual. Longe de ser uma peça de teologia, o conto se assemelha muito mais a uma confissão de não-pertencimento a qualquer das realidades descritas, se entendermos Céu e Terra como limites da liberdade e da identidade humanas, ou limites da individualidade e do externo ao indivíduo:

Livre e confiante cidadão da Terra, eis que está preso a uma corrente longa o bastante para the proporcionar liberdade sobre todo o espaço terrestre; conquanto longa apenas de maneira a que não o solicite coisa alguma fora dos limites da Terra. É ao mesmo tempo livre e confiante cidadão do Céu, e eis que está preso a igual corrente celeste.

\footnotetext{
270 "Sempre que as energias intelectuais estão intencionalmente concentradas no mundo exterior (...) tendemos a ignorar o processo subjetivo imanente à esquematização e a colocar o sistema como a coisa mesma. Como o pensamento patológico, o pensamento objetivador contém a arbitrariedade do fim subjetivo que é estranho à coisa". ADORNO, p. 180 apud SAFATLE, 2009, loc.cit.

${ }^{271}$ SAFATLE, ibidem.
} 
Quando pende muito para a Terra, estrangula-o a coleira celeste; quando pende muito para o Céu, estrangula-o a coleira terrestre...

Tem todavia todos os recursos, sente isso; sim, mas obstina-se em negar que tudo se deva a um erro inicial na fixação dos grilhões ${ }^{272}$.

Ao abdicarmos da visão teologizante das obras de Kafka ${ }^{273}$, esta dualidade contida no pequeno conto pode também ser entendida como um confronto entre a dominação da natureza ("sobre todo o espaço terrestre"), característica do sujeito iluminista conforme Adorno, e a dominação/repressão de si. Como nunca atingimos nem o céu ou a terra, nunca ocorre o domínio completo de nenhum dos polos. O mundo das obras é frio, sem vida ou natureza, já que o mundo que nos cerca está

totalmente - mais: totalitariamente - institucionalizado: ou seja, não há mais aquele saldo vacante e inaproveitado que nós costumamos reverenciar ou fruir como "natureza". Essa falta de natureza no mundo kafkiano é verdadeira na medida em que ocupa tudo aquilo que existe - pelo menos virtualmente - como matéria-prima ou fonte de energia, e extermina tudo 0 que seja inaproveitável, mesmo homens. ${ }^{274}$

A questão passa a ser se o sujeito reside nesta projeção do Eu sobre o mundo ou não. Em uma perspectiva adorniana, o sujeito se mostra como um constructo onde "a subjetividade coletiva, a subjetividade individual e o mundo objetivo, cada um em seu devido lugar, apoiam-se

\footnotetext{
${ }^{272}$ EFK, p. 199

273 "É da história 'Josefina', muito bonita, mas - fato estranho - relativamente desconhecida, que se deduz quão pouco Kafka concebeu seus escritos como peça de teologia judaica" (ANDERS, 2007, p. 126). O autor se perfila aos analistas que consideram a interpretação de Max Brod sobre a obra de Kafka, notadamente mística e teológica, como incapaz de captar sua dimensão completa. Anders apresenta Josefina, a camundongo que canta e supõe proteger o povo, mas na verdade é protegida por ele, como uma analogia à religião judaica, considerando sua voz "um intermezzo" na história de seu povo. Por extensão, Anders defende que o recurso à mística judaica, mesmo existindo em certo grau, não é a chave de interpretação correta para dar conta da complexidade da obra de Kafka.

${ }^{274}$ ANDERS, id, p. 125
} 
entre si operando uma dialética da não-identidade"275. Para Adorno este sujeito surge da confrontação entre pensamento e individualidade com os campos empíricos do saber ${ }^{276}$.

Se formos buscar tal problemática na obra de Kafka, ela se mostra na perda da identidade do indivíduo frente ao mundo e da busca pela rememoração dessa mesma identidade, como Gregor Samsa insiste durante todo o seu drama. Ou seja, em uma relação dialética indivíduomundo, eu-outro, buscando superar a lógica identitária que norteia o entendimento do eu e do mundo.

275 JAY, M. in SHOLLE, D. Subject of Adorno. International Communication Association, San Diego, CA, 27/05/2003. Disp. http://www.allacademic.com/meta/p112007_index.html

${ }^{276}$ Tal postulação vai de encontro ao projeto geral do filósofo alemão que, ao contrário da afirmação de Hegel de que a filosofia tem por objetivo "conhecer o que é", considera que a filosofia tem "a tarefa de conhecer o que não é mais, ou seja, de descobrir por que foram vedadas as possibilidades segundo as quais seria possível instituir uma vida melhor aqui e agora, respondendo porque a humanidade, como se lê no começo da Dialética do Esclarecimento, "em vez de entrar em um estado verdadeiramente humano, está se afundando em uma nova espécie de barbárie". (BEHRENS, R p. 2) O esclarecimento, enquanto evolução do pensamento, tem como objetivo a superação do medo (ou do irracional, do mito). Porém, quanto mais esclarecido, o mundo estranhamente recai com maior intensidade no dito irracional. Este processo é detectado na observação do cruzamento entre pensamento filosófico e "ciências particulares": o voltar-se da filosofia (razão crítica) sobre o mundo na busca de uma resposta para suas próprias questões. Deve-se rumar em direção ao tecido da realidade para tentar buscar as respostas que possam superar esta aparente aporia na qual a racionalidade contém em si os germes da barbárie. Porém, é a própria racionalidade - o pensamento que incorpora em si a crítica à sua própria regressão - que pode ser o caminho para libertação deste problema. Safatle, interpretando tal relação, afirma que isso pode nos indicar a existência de objetos "que só podem ser apreendidos na intersecção entre práticas e elaborações conceituais absolutamente autônomas e com causalidades próprias" (SAFATLE, 2009, p.4) e que é impossível "apreender (ergreifen) a totalidade da realidade (Wirklichen) através da força do pensamento" (ADORNO, apud SAFATLE, idem). Desta forma, o que leva Adorno a interrogar temas tão diversos em sua obra é a tentativa de achar uma resposta ao enigma da dialética entre razão e barbárie, buscando no mundo as marcas que permitem o entendimento do problema. É desta fragmentação temática, da articulação entre os assuntos, que surge a força de seu pensamento, pois é neste entrecruzamento que se mostram as verdadeiras interrogações que perpassam o próprio funcionamento do real, as fraturas e oposições invisíveis sob um manto de homogeneidade. No que é produzido na sociedade estão expressas as contradições que a compõem, as quais se mostram de Ulisses até a Indústria Cultural, da perda de sentido do "eu" e a desumanização de si até a repressão das pulsões como uma tentativa malsucedida de domínio da natureza interior; do entrelaçamento entre civilização e barbárie até a "autodestruição do Esclarecimento"; do predomínio da razão abstrata (instrumental) até a mentalidade de ticket e a padronização do pensamento sob um manto de progresso e evolução, que guarda em si o fracasso do pensar. Racionalidade e irracionalidade dialeticamente ligadas, colocando o homem (sujeito/objeto deste mecanismo) em constante confronto com este sistema. 
Essa imersão dos personagens em um mundo estranho tenta responder à pergunta de "como o que nasce no interior de uma situação pode servir de ponto de fuga, como perspectiva que permite criticar esta própria situação"277.

Buscar o Outro na obra de Kafka, surpreendentemente, pode nos levar à investigação do interior dos próprios personagens, o Eu da obra. Como já ventilado na análise do duplo, seria possível imaginar que a construção dos protagonistas de cada novela ou conto de Kafka usa a oposição de características como técnica para lhes conferir esfericidade ${ }^{278}$. Um personagem contém a si mesmo e sua nêmese, seu duplo oposto. Um outro Eu, assim como as técnicas de filmagem permitem a sobreposição da película para que o ator contracene consigo mesmo.

Ou ainda, recorrendo novamente a Carone, os textos de Kafka são construídos para exibir simultaneamente as coisas como são e como são percebidas pelo olhar alienado (alienado de si, estranhado, um outro que é o próprio eu).

Cada personagem, assim, se mostraria cindido já em sua origem e "contracenaria" consigo mesmo na narrativa, mas isso se daria tanto na diferença de percepção ser-mundo (a reação da família à animalidade de Gregor em contraste com a consciência de si, deste como ainda humano) como na percepção de si mesmo (ainda em A Metamorfose, o processo de domínio do corpo-animal por Gregor equivaleria ao domínio de um outro eu). A incapacidade de comunicação de Gregor com sua família o coloca na posição de dependência, assim como uma criança sem a possibilidade de expressar a consciência de si, mesmo que esta já exista em algum grau.

Grete, neste momento, assume para si o papel de mantenedora de seu irmão, papel que exerce até sua tentativa infrutífera de retirar a imagem da dama de peles do recinto, ação que provoca uma reação hostil

\footnotetext{
${ }^{277}$ SAFATLE, 2009, p.7.

${ }^{278}$ Amor/ódio (Grete), decisão/indecisão (Josef K.), animal/humano (Gregor e Rotpeter), dever/desejo (o médico rural), ação/inação (o homem do campo em Diante da Lei), sofrimento/sucesso (a bailarina em Na Galeria), entre outros.
} 
de Gregor. Assumir a situação de dependência completa de Grete 279 simbolizada na retirada do quadro equivale a assumir a perda de humanidade, a incapacidade de si, a perda do Eu: "Elas Ihe esvaziaram o quarto; privavam-no de tudo que the era caro"280.

Ao se insurgir e provocar a ira da irmã e da família, o indivíduo Gregor se rebela contra a tentativa de formatação de um novo Eu, que começa com um quarto todo vazio ${ }^{281}$. Ao mesmo tempo que soa como um retorno à dependência edipiana, pode significar seu contrário: não voltar para a completa dependência.

Ser sujeito é ser expressão de si, seja esta formada pela racionalidade ou pelas intensidades e desejos. A impossibilidade da expressão clara não significa a inexistência do ser, mas a existência de dois seres no mesmo: o que quer expressar e o que não é compreendido. Há um Gregor e um duplo-Gregor simultâneos.

Esta outra identidade dos protagonistas, o duplo, poderia estar no próprio narrador, como alguém que falasse de si mesmo na terceira

${ }^{279}$ Este ponto é considerado por Deleuze como o momento de reedipianização do texto de $A$ Metamorfose, pois Gregor não abandona todos os seus resquícios de humanidade (deste devir-animal) e retorna a uma figura materna abandonando a relação esquizo com a irmã. Isso desembocaria na mudança de comportamento dela em relação ao irmão, que de um ser com nome passa a ser um "isto". Grete, ao assumir o papel de mãe-nutridora, passa a estabelecer uma relação edípica e com forte carga sexual com o irmão, que é rompida por este. É possível interpretar esta visão esquizo, mesmo com cuidado, de forma diversa do proposto por Deleuze: apesar do retorno à figura da mãe, o que não é explícito na imagem da mulher de peles ( $A$ Vênus das Peles de Masoch, recorrendo a outro texto deleuziano?), o que talvez ocorra aqui seja uma ação de afirmação de identidade e de reelaboração do passado.

${ }^{280}$ EFK., p. 264. Os móveis e o ambiente do quarto de Gregor acabam por nos remeter, novamente, ao conceito de ruína benjaminiano, pois o quarto do homem-inseto virou o lugar das "coisas que não se podia vender mas que não se podia jogar fora" (EFK., p. 276); os resquícios do passado que ainda precisam ser ressignificados. Aquilo que compunha sua vida pessoal e familiar, da qual os demais integrantes da família buscavam uma forma de se livrar ou ao menos ocultar de sua vista cotidiana, assim como dos hóspedes. O quartoinseto é o segredo de família, assim como um indivíduo o é, de certa forma, com seu eu formado e deformado pela influência do triângulo familiar e da interação deste com os demais triângulos (burocrático, funcional, econômico, social), exemplificados nos três hóspedes e no gerente. Após a morte de Gregor, a família resolve se mudar para uma casa menor, que não fora escolhida pelo caixeiro-viajante, deixando para trás aquilo que rememoraria o episódio.

${ }^{281}$ Um sujeito a ser preenchido, um nome que não se refere a nada. "O indivíduo não tem mais uma história pessoal" (HORKHEIMER, p.163). Novamente, a limpeza do quarto é simbólica, por ser a retirada desta história de dentro do ambiente-sujeito. 
pessoa? Tal divisão (dividuum) explicitaria o vazio ao qual o personagem se refere e ao mesmo tempo sugeriria um ponto de resistência entre tais identidades, um limite a não ser ultrapassado entre elas? Se, conforme já visto, o narrador não-onisciente de Kafka está tão jogado dentro das situações quanto os personagens, pode ser em si a projeção de um personagem, porém fora do jogo entre enunciação e enunciado - como se realmente olhasse a cena por cima do ombro do protagonista, mas sem ser ele. Como um doppelgänger ${ }^{282}$ : o que se acreditava não-divisível (individuum ${ }^{283}$ ) explode em crise. O sujeito narrador em Kafka é a fratura do $\mathrm{Eu}^{284}$.

Escrevo de forma diferente do que falo; falo de forma diferente do que penso; penso de forma diferente do que deveria pensar - e assim se segue até as profundezas mais escuras do infinito 285 .

${ }^{282}$ Goethe narra em sua autobiografia o que teria sido um encontro que teve com seu duplo na estrada para Drusenheim. Goethe contempla a si mesmo andando a cavalo e a lembrança deste estranho encontro se torna um pensamento reconfortante para ele quando é obrigado a deixar a Alsácia, comparável à retomada da posse de si. Kafka, como leitor ávido de Goethe, certamente não desconhecia esta passagem. Se esta situação influenciou a criação de sua técnica narrativa é outra história, visto que é sabida a atração do escritor checo pelo uso literal de expressões alegóricas (algo a que a expressão "réplica que anda" poderia remeter), o que abre uma interessante possibilidade.

${ }^{283}$ Tradução latina do grego atomon. A construção da individualidade parte da ideia da existência de uma singularidade original sobre a qual o conceito de sociedade e civilização se baseiam e que rege a percepção/ordenação do mundo a partir de si. Isso é perceptível, de forma explícita ou não, em todo o pensamento ocidental (a mônada leibniziana é um exemplo claro, assim como o cogito cartesiano). Conforme Horkheimer, a evolução do conceito do $\mathrm{Eu}$ é um espelho da dupla história do esforço do homem em submeter a natureza e da submissão do homem pelo homem. Assim, tal conceito nasce de forma complicada, pois não há uma contraposição rígida entre natureza e sociedade ou natureza e indivíduo: as relações entre tais "polos" são mediatizadas pela práxis. Não há, como já dizia Marx, uma separação do sujeito em relação ao mundo onde vive, uma subjetividade FORA da natureza, da mesma forma que a natureza não pode ser separada do humano. A ruptura do conceito de Sujeito é, paradoxalmente, um movimento no qual este se reafirma, mas sem a ilusão de uma subjetividade "objetiva", ou seja, estratificada.

${ }^{284}$ Por isso, para Deleuze, Kafka prolifera sobre si nos textos. Proliferação que não é um simples desdobramento, porque um desdobramento pressuporia um algo inteiro que se replica. Aqui a questão é outra, pois a multiplicidade deste Eu é um a priori. Não se trata de um Eu estratificado, mas de uma subjetividade múltipla, composta de diversas facetas. Por meio das obras, conhecemos a multiplicidade da personalidade kafkiana.

${ }^{285}$ Carta a Ottla, 10 de julho de 1914. Esta multiplicidade de visões - ou de Eus - a que Kafka se refere mostraria o fracionamento da noção de sujeito de enunciação, e por conseguinte da noção de Sujeito, em sua obra? 


\subsection{As sobras da razão}

Os personagens que mais se mostram descolados daquilo que poderia ser interpretado como normal são, muitas vezes, a chave para o entendimento da narrativa, pois denunciam, em sua existência, que tal loucura pode ser entendida como a ilusão de liberdade particular e de individualidade numa sociedade cujo cerne é a exploração do ser e a extinção da autonomia do sujeito, substituída por um simulacro de individuação e um pensamento formatado produzido industrialmente.

No imaginário das obras do autor checo, a "loucura objetiva" é mostrada em seu extremo - e paradoxalmente como um caminho para a retomada da razão. É interessante reparar que, para Adorno, Kafka aborda este processo simultaneamente no indivíduo e no tecido social, em ambas as esferas: "como na época da crise do capitalismo, o peso da culpa é tirado da esfera de produção e atribuído a agentes da circulação ou a pessoas que prestam serviços: viajantes, bancários e garçons ${ }^{286 "}$.

O sistema não é questionado diretamente enquanto elemento de desagregação da individualidade: em $O$ Processo, as reações de Josef $\mathrm{K}$. às particularidades do processo se voltam a fatos que não tem relação direta com o procedimento em si: o mal-estar ante a presença dos funcionários, a irritação com a postura protetora de seu tio ou a exasperação em relação a Leni e o advogado, como se estes fossem responsáveis pela situação. Mas desta forma, sem citar nomes, um duplo recado é dado: o sistema que perpassa os homens, e é fruto da apatia destes, tem sua máscara arrancada exatamente pela aparente inação dos personagens. Ao confiarem na coerência do sistema, este os desampara como era de se esperar - e é esta a culpa que carregam: acreditar que "assim é".

${ }^{286}$ AsK, pag. 256 
Kafka não glorifica o mundo pela subordinação, antes resiste a ele pela não-violência. Diante dela, o poder deve reconhecer-se como aquilo que realmente é. Kafka conta com isso. O mito deve se prostrar diante da própria imagem no espelho. Os heróis de O Processo e de O Castelo tornamse culpados não por sua própria culpa - eles não têm nenhuma - mas porque procuram trazer a justiça para o seu lado $^{287}$.

A conformação do indivíduo à administração da sociedade é o que dissolve a instância do subjetivo e dá ao sistema (ou àqueles que se beneficiam dele) a posição de comando, até o ponto em que o próprio sistema ultrapassa a simples relação de poder e dominação entre grupos. A sociedade administrada passa a reger todos os aspectos da realidade, não como uma conspiração perpetrada por um grupo, mas por simples inércia: a imposição de uma forma única de pensamento e ação (o sempre-igual que Adorno detecta na sociedade contemporânea) se dá pelos próprios integrantes do corpus social, que de tão afastados da possibilidade do pensamento reflexivo, perpetuam sua própria condição de alienação: "Integração é desintegração, e nela se encontram o encanto mítico e a racionalidade dominadora ${ }^{288 "}$.

No mundo do racionalismo extremo, a razão voltada a fins assume a posição da nova divindade, replicando a ideologia que perpassa a sociedade, retirando do indivíduo sua autonomia e dando a tudo um ar de semelhança e indiferenciação.

A semelhança cumpre um papel crucial na manutenção do status quo, pois qualquer espaço para o surgimento da diferença pode trazer em si o risco da ruptura deste tecido social:

Sistemas políticos e de pensamento não desejam nada que não se thes assemelhe. Porém, quanto mais fortes ficam, quanto mais reduzem tudo o que existe a um denominador comum, tanto mais oprimem e se afastam do que existe ${ }^{289}$.

\footnotetext{
${ }^{287}$ AsK, p. 269

${ }^{288}$ AsK, p. 253

${ }^{289}$ AsK, p. 253
} 
A obra de Kafka, na visão tanto de Adorno como de Benjamin, se opõe a esta semelhança forçada e forjada pelas ferramentas de dominação do sistema exatamente por seu hermetismo, meio pelo qual denuncia e resiste à reificação, expressando-a na forma literária: "a razão está por trás da obra, revelando a loucura objetiva através do principium stilisationis ${ }^{290 " . ~ O ~ c o n t r a s t e ~ e n t r e ~ u m a ~ o r g a n i z a c ̧ a ̃ o ~ s o ́ c i o-p o l i ́ t i c o-~}$ econômica que busca incessantemente sua auto-replicação e a arte, entendida como tudo aquilo que não é voltado apenas à autopreservação 291 , surge na obra do escritor checo exatamente por meio da apresentação in extremis da disposição maquínica e industrial da sociedade administrada. Ao apresentar a máquina, Kafka a desnuda, já que "nenhum mundo poderia ser mais homogêneo do que o mundo sufocante que ele comprime em totalidade por meio da angústia do

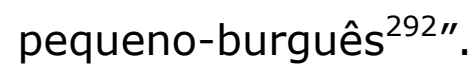

Kafka se recusa a abraçar a vida danificada (a vida que não é mais vida, na qual apenas sobrevivemos ${ }^{293}$ ) e efetua sua denúncia sobre seu

\footnotetext{
${ }^{290}$ AsK, p. 263

291 Este choque está presente na expressão pela qual a filosofia de Adorno é mais conhecida. O oxímoro "Indústria Cultural" guarda em seu interior o mesmo conflito que o humano/indivíduo/sujeito enfrenta na sociedade administrada - a aporia entre um sistema cuja lógica, permeada pelas leis do capital, exige e executa a reprodução de padrões identitários já formatados e destinados a finalidades específicas contra a necessidade e impulso de expressão autêntica tanto do indivíduo que busca a consciência de si (sua autonomia no sentido kantiano) como da coletividade em busca de uma organização condizente com sua realidade. Replicar e condicionar industrialmente este Geist somente é possível por meio da alienação, no sentido do não-reconhecimento de si e do outro, e da veiculação de uma ideologia específica que ocupe o lugar da cultura desta sociedade. Por isso, mais do que transformar cultura em mercadoria, o grande segredo da Indústria Cultural é a transformação da mercadoria em cultura, ou seja, quando a lógica da mercadoria dita o modo de vida da sociedade e do indivíduo, por extensão. Mais do que peças na máquina, somos produtos na prateleira. Desta forma, o caráter de entretenimento da Indústria Cultural opera uma dupla função: direcionar este conflito do sujeito em relação ao Eu para um apaziguamento provisório e simultaneamente reforçar a inexorabilidade do sistema por meio da difusão velada ou não da ideologia que o suporta.

${ }^{292}$ AsK, p. 252

${ }^{293}$ O conceito de vida danificada aparece com o entendimento de que o viver se transformou em "modo de vida" e o indivíduo se encontra subordinado e iludido pela "embalagem positiva" ou espetacular do sistema em que vive, não sendo possível a autonomia. Para Adorno, a vida danificada surge como efeito de uma coerção funcional do indivíduo, ou a circunstância em que o membro particular da espécie humana se vê condicionado por uma
} 
tempo a partir de seus personagens também danificados, retratos de nós mesmos, aqueles que não são os heróis da narrativa histórica, os mantenedores do mecanismo social que as descarta: "Quem parece supérfluo não são os poderosos, mas os heróis impotentes ${ }^{294 ",}$ e em sua impotência tais heróis se tornam fundamentais.

Assim como em outros momentos de sua produção filosófica, a ideia de Adorno de que o pensamento e a arte devem colocar "sua afinidade mimética com o que há de mais morto e arruinado na realidade social ${ }^{295 "}$ pode ser apreendido de sua análise de Kafka: buscar naquilo que parece estar mais formatado ou excluído pelo sistema os espaços para sua ruptura ${ }^{296}$.

Desta forma, estranhamente - pelo estranhamento - a própria saída surge desta aparente falta de saídas. Da contradição existente na obra de Kafka entre a replicação e a recusa, entre a reificação e a angústia, podemos vislumbrar um devir. Mas este não é, necessariamente, a conciliação de tais opostos. Aqui a dialética opera de forma negativa ${ }^{297}$ : sujeito e objeto, ideia e natureza, razão e experiência não estão conciliados, mas imbricados. Desta forma, a tensão entre eles se mantém.

rede funcional ou uma circunstância de descolamento entre o progresso da cultura material e o progresso no campo da sua liberdade e da sua felicidade. O ser acaba por se submeter às coisas que cria, ou seja, "o trabalhador põe sua vida no objeto; porém agora ela já não Ihe pertence, mas sim ao objeto" (MARX, 2001, p.112). A alienação não é apenas em relação ao outro, é a alienação de si mesmo, de sua própria humanidade, nos transformando em escravos das coisas que fazemos. Este é o dano maior que a sociedade provoca no indivíduo. Em Kafka, o estranhamento provocado por sua temática, narrativa e pela forma de sua obra é, segundo Adorno, o caminho para a libertação desta vida danificada, por nos obrigar ao questionamento.

${ }^{294}$ AsK, p. 252. A frase nos remete à visão de Baudelaire sobre o homem na modernidade, também abordada por Benjamin: a sensação de impotência e angústia perante o mundo.

295 SAFATLE, 2005, pp. 21-45.

${ }^{296}$ Neste sentido a insistência adorniana nos aspectos da obra de Kafka que dificultam o entendimento também nos remete à sentença de Beckett "I can't go on, I'll go on": o ponto onde a saída parece estar totalmente interditada é exatamente onde se deve insistir. A partir da força da própria razão, romper a escravidão em que a razão dirigida a fins nos coloca. É necessário questionar a ilusão da subjetividade a partir da própria força do sujeito. Como os problemas não-resolvidos da sociedade voltam na forma da obra de arte, é na própria forma que surge a possibilidade de confrontação destes problemas. Não à toa, Beckett também é objeto da análise do filósofo alemão.

${ }^{297}$ Para Adorno, a experiência estética se caracteriza como a forma mais adequada para o conhecimento pois nela é possível "ir além do conceito, através do conceito" (DN, p. 22) 
A melancolia tende, então, a seu extremo oposto: o humor negro. A resignação empurra em direção à ação. A partir do que parece ser um obstáculo, mostram-se as condições para sua superação; "estar em sua própria língua como estrangeiro ${ }^{298 " ~ g e r a ~ o ~ u s o ~ m e n o r ~ d a ~ l i ́ n g u a . ~ P a r a ~}$ superar a visão psicanalítica da obra, exige-se uma polidez esquizo ${ }^{299}$, uma psicanálise in extremis ${ }^{300}$. Para denunciar o real, levá-lo a seu limite, por superconformidade. Kafka executa operações de linguagem para levala até um momento de pane - e esta pane é o que realmente desvela o sentido da linguagem ${ }^{301}$.

Ao dizer que o "efêmero, ao ser perpetuado, é atingido por uma maldição ${ }^{302 ", ~ A d o r n o ~ a p o n t a ~ o ~ f a t o ~ d e ~ q u e ~ e s t a ~ s e n s a c ̧ a ̃ o ~ d e ~ i n q u i e t a c ̧ a ̃ o ~}$ provocada pela obra também pode ser absorvida ou replicada de forma industrial pelas ferramentas de controle, com a consequente perda de impacto da obra. Porém, ainda permanece um ruído, uma recusa à ideia de integração total : "não há sistema sem resíduo ${ }^{303 " . ~ L o c a l i z a r ~ e s t e ~}$ resíduo é a tarefa.

\footnotetext{
${ }^{298}$ K., p. 41

${ }^{299}$ K., p.26

${ }^{300}$ Tal abordagem soa muito similar à ideia de hiperconformidade conforme Adorno.

301 Surge aqui uma interessante possibilidade de diálogo entre Kafka, a lógica do sentido deleuziana e a análise adorniana sobre a linguagem na Teoria Estética, a ser desenvolvida posteriormente.

${ }^{302}$ AsK, p. 248. Este é um ponto de discordância entre as visões de Adorno e Benjamin relacionado à dinâmica obra/momento histórico. Se Benjamin considera que o momento transitório, cristalizado na obra, já permitia a apreensão do real de forma plena, Adorno necessariamente insere este movimento do fragmentário, do efêmero, dentro de um processo dialético. Se Benjamin abdica, de certa forma, da totalidade em prol do instante, do arruinado na sociedade, Adorno concebe a visão destas ruínas como um tipo de totalização negativa, um todo de múltiplos instantes. Sem o entendimento de seu contexto e sem seus desdobramentos, o efêmero pode ser facilmente reificado.

${ }^{303}$ AsK, p. 253. O resíduo nos aponta a existência de um Outro que se define de forma negativa. Para SAFATLE (2005, p. 39), "na estética adorniana, a mímesis não está diretamente ligada ao imperativo de reconciliação com a imagem positiva da natureza, como poderíamos esperar em uma reflexão tradicional sobre a mímesis na arte. Adorno é extremamente crítico em relação aos projetos que procuraram recuperar algo desta reflexão tradicional como, por exemplo, o programa de reconstituição da racionalidade musical a partir da tentativa de posição de protocolos de afinidade mimética com a faticidade imanente e não-estruturada do sonoro. Neste sentido, a análise da crítica adorniana a John Cage é extremamente instrutiva. Na verdade, a exigência adorniana passa pela necessidade de a arte pôr sua afinidade mimética com o que há de mais morto e arruinado na realidade social", sendo este o resíduo que se revela.
} 
Mesmo com a elevação de Kafka à categoria de estilo literário e de "kafkiano" a adjetivo - enquadrando-o em escolas e sistemas de pensamento ${ }^{304}$ - o estranhamento, elemento fundamental na própria obra e na leitura que se faz dela, nos desafia e provoca nosso pensamento a sair de sua zona de conforto.

Desta forma, a prosa de Kafka ${ }^{305}$ apresenta uma dimensão política no sentido de que abre lacunas ou fissuras no tecido aparentemente homogêneo da sociedade administrada, operando como pontos de apoio para a negatividade. Mais do que isso, podem servir como inspiração para a práxis.

Ao ouvir o som do violino tocado por sua irmã, Gregor modifica sua ação cotidiana de recolhimento e resolve sair do quarto, correndo o risco da visibilidade, mas não num arroubo de coragem ou afirmação e sim como consequência de uma completa exasperação. "Sua indiferença diante de tudo era grande demais para que, como antes, tivesse ficado de costas e se esfregado no tapete várias vezes durante o dia ${ }^{306}$."

E a indiferença o faz agir e ir para a sala de estar: a ação aparece exatamente a partir da aparente inação, da situação de maior imobilidade ou alienação.

Independente da reação escandalosa dos hóspedes, algo foi feito, algo sai do dito padrão ou do esperado. A literatura kafkiana evidenciaria assim a dimensão subjetiva e social que os indivíduos perderiam na sociedade administrada ${ }^{307}$, podendo, na visão de Adorno, apresentar

${ }^{304}$ Podemos imaginar que este enquadramento tentado em relação à obra de Kafka, tanto pelas diversas interpretações de sua produção literária como pelos estereótipos existentes a respeito de sua dificuldade de compreensão, possa ter também o objetivo de amortecer o potencial questionador da obra. Apresentar uma "solução" para o enigma Kafka equivaleria a achar uma fórmula para a produção em série de textos com uma certa atmosfera sombria, fantástica e hermética, porém sem a força de provocar o estranhamento.

${ }^{305}$ Assim como a filosofia de Adorno e a de Deleuze, dentro da questão abordada neste trabalho.

${ }^{306}$ EFK., p.279

${ }^{307}$ Para Adorno, os processos que ocorrem na realidade histórica atual - e nossa percepção desta realidade - estão condicionados pelos processos econômicos visíveis, por exemplo, na Indústria Cultural, que replica a ideologia dominante em um processo de duas vias: na primeira, os bens culturais padronizados já trazem em si uma "resposta" a qualquer aresta ou questionamento que possa surgir. Na segunda, a produção cultural em todas as suas 
também a forma pela qual esta dimensão pode ser "resgatada", o que não se dá senão em um movimento dialético, negativo e de confrontação/crítica, levando a administração social a sua própria ruína.

instâncias é subordinada à lógica de replicação do capital. Na sociedade de consumo do capitalismo tardio, "cultura e estética se amalgamam com a produção e a propaganda para criar um estilo de vida focado no consumo de bens, serviços, imagens de massa e espetáculos" (KELLNER, in CARSON, 2011), perdendo capacidade de operarem como fatores de deslocamento do ponto de visão. O efeito disso é a perda da capacidade de reconhecimento de si e do outro, substituída por uma pseudo-consciência de si mediada "entre opções disponibilizadas pelo mercado" (SAFATLE, 2002, online) e, por conseguinte, acomodada em si e para si. 


\section{A ESTÉTICA POLÍTICA}

De todas as interpretações já realizadas sobre a obra de Kafka, talvez uma das dimensões menos exploradas seja a existência de um caráter eminentemente político em suas obras ${ }^{308}$. A definição de política, aqui, poderia ser vista de forma mais ampla do que as relações e disputas por um poder central ou um aparelho de estado, mesmo levando-se em conta a simpatia que Kafka teria por alguns grupos anarquistas - e talvez até mesmo por isso, visto esta ser uma forma de organização social na qual o conceito de relação de poder é duramente atacado ${ }^{309}$.

É preciso ter em mente que a tensão arte-ideologia-sociedade deve necessariamente operar em um substrato espaço-temporal. A arte tem também na sua forma, não apenas no conteúdo, os registros da experiência histórica. A forma da obra é indissociável do trabalho do conceito e da reflexão, mas isto não os iguala. Uma obra - artística, intelectual, etc. - é pensada de forma completa e significa em sua totalidade, mas esta totalidade não é um em-si, mas sim "a totalidade da

308 "É óbvio que não podemos reduzir a obra de Kafka a uma doutrina política, seja ela qual for. Kafka não produziu discursos, mas criava indivíduos e situações, e exprimia em sua obra sentimentos, atitudes, um Stimmung. O mundo simbólico da literatura é irredutível ao mundo discursivo das ideologias: a obra literária não é um sistema conceitual abstrato, como doutrinas filosóficas ou políticas, mas criação de um universo imaginário concreto de personagens e coisas." (Cf. GOLDMANN, 1959, apud LOWY, 2005)

${ }^{309}$ A críptica frase "Não esquecer Kropotkin" em seus diários traz Kafka a uma problemática política insuspeita na análise mais difundida sobre sua obra, que versa sobre os temas do tribunal íntimo ou de sua natureza teológica. O líder anarquista russo Piotr Kropotkin, considerado um dos fundadores do anarco-socialismo, era leitura comum entre os jovens no círculo de amizades de Kafka, segundo dados constantes nos textos de Brod e Janouch sobre o escritor (Cf. LOWY, 2005). O próprio Kafka teria recebido de presente, segundo MARES (apud WAGENBACH), um exemplar de Palavras de um Rebelde, obra do pensador russo. Independente da veracidade do relato de Mares, bastante contestada, pode-se avaliar que o círculo de Praga no qual o escritor estava inserido não estava alheio ao debate ideológico da época. A simpatia pelo anarquismo ou anarco-socialismo que seria dispensada por Kafka estaria materializada em expressões como "tudo é hierarquizado, tudo está nos grilhões" e, ao se referir ao capitalismo, em afirmações como "um sistema de relações de dependência". Para Lowy, aí residiria um indicativo do conhecimento de Kafka sobre o anarquismo, haja vista que sua crítica não se atém ao modo de produção e à economia, como Marx, e sim às relações de poder. Trata-se de uma visão política de uma estrutura econômica. 
inigualável experiência do pensamento como atividade humana ${ }^{310 ",}$ localizada no espaço e no tempo.

A dicotomia forma e conteúdo é abandonada em prol de uma construção histórico-estética, uma tensão entre o que é mostrado e o como é mostrado que nos permite ver pelas brechas do tecido do real, superando assim as armadilhas do discurso que busca organizar tal realidade. Nas palavras do próprio Kafka,

Escrever é o que me sustenta. Mas não seria mais acurado dizer que é o que sustenta este tipo de vida? O que não significa, é claro, que minha vida é melhor quando eu não escrevo. Ao contrario, às vezes é muito pior, quase insuportável, e inevitavelmente termina em loucura. Isso, claro, ocorre apenas se assumo que sou um escritor até mesmo quando não estou a escrever - o que é de fato o caso: e um escritor que não escreve é, de fato, um monstro cortejando a insanidade ${ }^{311}$

Desta tensão, dialeticamente, insinua-se aquilo que resiste ou desafia a sua própria representação, aquilo que é mais do que nos é mostrado imediatamente: a dimensão estético-política da realidade. Kafka atribuía tal capacidade de desafiar a natureza amortecida do fruidor da obra à literatura ${ }^{312}$. Logo, se há uma ligação entre o real e a obra, esta terá uma dimensão política se este termo for entendido como existência social, o que abarca as relações pessoais, profissionais e as simpatias ideológicas do autor.

Das figuras de autoridade às ineficiências do sistema retratado nas obras, tudo se torna política, inclusive a própria literatura kafkiana. Este ponto será investigado a partir de agora.

\footnotetext{
${ }^{310}$ NOYAMA, S. p. 139

${ }^{311}$ Carta a Max Brod, 5 de julho de 1922.

${ }^{312}$ Cf. Nota 188
} 


\subsection{Literatura a contrapelo}

A literatura é uma violência organizada contra a fala comum ${ }^{313}$

O estranho das relações humanas apresentadas por Kafka em suas obras é, para alguns autores, reflexo e eco de suas relações pessoais. $O$ escrever em Kafka poderia ser visto como uma forma de rearticulação das relações entre escritor e vida: a literatura não é mais constituída a partir de imagens ou reconstruções imaginárias do mundo, e sim a partir da experiência do mundo, dando sentido a este. O próprio Kafka observa, sobre $O$ Processo, em uma anotação no Diário:

Estou escrevendo desde há alguns dias [...] Não me sinto, hoje, tão protegido [...] pelo trabalho como há dois anos, mas adquiri um sentido - minha vida regular, vazia, insensata de celibatário, tem uma justificativa ${ }^{314}$.

A literatura, o ato de escrever, funcionaria como um canal para o desejo de viver de Kafka, espremido entre um emprego relativamente estável e suas já anedóticas dificuldades de relacionamento com as pessoas. Usando a linguagem de escritórios para um significado oposto ao que ela expressaria de forma direta, Kafka surge como criador de um novo continente, uma nova constelação tanto para sua expressão pessoal como para a literatura - e exatamente por isso o articulador de um novo vocabulário que reconfigura a linguagem e seus significados ${ }^{315}$.

\footnotetext{
313 JAKOBSON, apud EAGLETON, 2006, p.3

${ }^{314}$ Diário, 15 de agosto de 1914, em CARONE, p.67.

${ }^{315}$ Por este prisma, a temática kafkiana não é a fraqueza, a sublimação de um mundo demasiado hostil ou uma torre de marfim, mas um rizoma, uma toca que mostra novas possibilidades de conexão e superação. "Uma linha de fuga, sim - mas não um refúgio" (K, p. 41). Captar esta diferença se faz a partir da leitura da obra, de seu funcionamento como máquina: a leitura é tão experimental quanto a escrita teria sido. Deleuze considera que a leitura da obra, em si, não deve seguir um modo estruturante, devendo ser experimentada.
} 
Ao contrário do uso cotidiano da linguagem, em que a comunicação é uma ferramenta social para troca de conhecimento, a linguagem literária ultrapassa esta utilização funcional. O pensamento literário se inicia quando a organização das palavras busca não mais explicitar o que é evidente, mas sim revelar novas possibilidades de compreensão do que é dito, buscando realizar uma aproximação real do que possa ser fato, consequência ou ficção ${ }^{316}$.

O estranhamento na literatura abriria, desta forma, tal possibilidade de desvelamento dos sentidos ocultos, encobertos pela linguagem prosaica. Se o léxico dos escritórios é a fala corrente no dia a dia burocrático, seu uso literário é em si a "violência organizada" em questão. A literatura se constrói como processo de organização e reapropriação de sentidos, por meio de um léxico (ou linguajar) fora de posição ou do que

\footnotetext{
"Só acreditamos numa experimentação de Kafka, sem interpretação nem significação, mas somente protocolos de experiência" (K, p. 7).

${ }^{316} \mathrm{Em}$ sua Filosofia da Composição, Poe detalha o processo de criação de O Corvo, e chama a atenção para o fato de que toda literatura busca, primordialmente, o uso da linguagem para provocar um efeito no leitor. "Há um erro radical, acho, na maneira habitual de construir uma ficção. Ou a história nos concede uma tese, ou uma é sugerida por um incidente do dia, ou, no melhor caso, o autor senta-se para trabalhar na combinação de acontecimentos impressionantes, para formar simplesmente a base da narrativa, planejando, geralmente, encher de descrições, diálogos ou comentários autorais todas as lacunas do fato ou da ação que se possam tomar aparentes, de página a página. Eu prefiro começar com a consideração de um efeito. Mantendo sempre a originalidade em vista, pois é falso a si mesmo quem se arrisca a dispensar uma fonte de interesse tão evidente e tão facilmente alcançável, digo-me, em primeiro lugar: "Dentre os inúmeros efeitos, ou impressões a que são suscetíveis o coração, a inteligência ou, mais geralmente, a alma, qual irei eu, na ocasião atual escolher?" Tendo escolhido primeiro um assunto novelesco e depois um efeito vivo, considero se seria melhor trabalhar com os incidentes ou com o tom com os incidentes habituais e o tom especial ou com o contrário, ou com a especialidade tanto dos incidentes, quanto do tom - depois de procurar em torno de mim (ou melhor, dentro) aquelas combinações de tom e acontecimento que melhor me auxiliem na construção do efeito." (POE, 1999, pp. 101-102). Tal uso da linguagem seria eminentemente operativo, ou seja, como processo do descrever e inscrever que não se separa do enredo descrito. Em Kafka, o efeito se mostraria pelo próprio uso intencional/literal das figuras de linguagem, e a intencionalidade é constitutivo do processo, do início ao fim do texto. Citando $\mathrm{POE}$, "só tendo o epílogo constantemente em vista, poderemos dar a um enredo seu aspecto indispensável de consequência, ou causalidade, fazendo com que os incidentes e, especialmente, o tom da obra tendam para o desenvolvimento de sua intenção". (idem, p.101). E o aforismo 26 de Kafka se encerra afirmando: "Existe um objetivo, mas nenhum caminho; o que chamamos de caminho é hesitação" (EFK, p. 193). Para alguém que se definia como um escritor mesmo quando não escrevesse, tal afirmação soa por demais interessante para se deixar de lado um paralelo entre vida e narrativa.
} 
se espera ${ }^{317}$. Isto provoca o choque e o estranhamento. Um fracasso bem-sucedido da estabilidade semântica, no qual o estranho se completa e opera no estranho.

Dentro desta abordagem, a introdução à edição norte-americana da obra de Deleuze sobre Kafka apresenta um interessante tour de force entre a visão deleuzoguattariana e a de Walter Benjamin, a começar da recusa que ambos fazem a determinadas leituras comuns sobre o escritor checo: a psicanalítica e a teológica ${ }^{318}$, pois estas reduziriam a força de Kafka ou a conflitos no seio familiar ou a um subproduto da ideia de que "o homem nunca tem razão em face de Deus ${ }^{319 ", ~ e m ~ p r e j u i ́ z o ~ d e ~ s u a ~}$ inserção no mundo. Para ambos, a obra kafkiana possui um caráter político - o caráter de referência direta à realidade e do entranhamento/estranhamento entre artista e meio social. Se Deleuze o abrigará dentro de seus postulados da literatura menor, Benjamin descartará de pronto a relação psicanalítica tão cara a outros

${ }^{317}$ Poderíamos supor que Kafka, que dominava alemão e checo de forma quase bilíngue, ao apreender o uso "de trabalho" do idioma alemão efetuou uma operação simples, bem humorada e que qualquer estudante de línguas já fez: ler as expressões idiomáticas ou os falsos cognatos de "forma literal"? O olhar do estrangeiro sobre a língua de uma região é um híbrido entre suas experiências pessoais e a incapacidade de compreensão completa daquele meio ao qual não se pertence em sua totalidade. Como a comunicação é uma necessidade da qual o estrangeiro não pode se furtar, 0 ato de comunicar deve, necessariamente, passar por um uso recursivo e extensivo da linguagem a ser compreendida. Este olhar estrangeiro pode ser aquilo a que Deleuze se refere quando observa que, para Kafka, há a "impossibilidade de não escrever, impossibilidade de escrever em alemão, impossibilidade de escrever de qualquer outra maneira."(K., p. 29) Lembremos que apenas $7 \%$ da população da região da Boêmia dominava o idioma alemão, percentual no qual se incluía Franz Kafka, que aprendeu alemão por obra de sua mãe, que fora alfabetizada em alemão e somente depois aprendera o checo. A região da Boêmia fazia parte do Império Austro-Húngaro. Praga, sede administrativa da região, concentrava o funcionalismo público do qual Kafka fazia parte e que usava o alemão como língua oficial para documentos, processos e procedimentos.

${ }^{318}$ Para BENJAMIN, "há dois mal-entendidos possíveis com relação a Kafka: recorrer a uma interpretação natural e a uma interpretação sobrenatural. As duas, a psicanalítica e a teológica, perdem de vista o essencial" (p. 152). Para DELEUZE, "os três temas mais deploráveis em muitas interpretações de Kafka são a transcendência da lei, a interioridade da culpa, a subjetividade da enunciação. Estão ligados a todas as estupidezes que se escreveram sobre a alegoria, a metáfora, o simbolismo de Kafka" (K., p. 68). Diga-se de passagem, diversas outras citações poderiam ser feitas a partir do texto de Deleuze, mas consideramos que esta dá conta de maneira exemplar, até mesmo por enumerar os problemas interpretativos, assim como Benjamin faz.

${ }^{319}$ Conforme a citação que Benjamin faz de Willy Haas in BENJAMIN, p. 153. Tal afirmação mostra-se bastante similar ao entendimento deleuziano. 
comentadores em prol de uma aproximação entre a dinâmica filho-pai e a relação homem-mundo:

O pai é a figura que pune. A culpa o atrai, assim como atrai os funcionários da Justiça. Há muitos indícios de que o mundo dos funcionários e o mundo dos pais são idênticos para Kafka ${ }^{320}$.

Essa visão é estranhamente similar a de Deleuze quando este diz que

Os juízes, comissários, burocratas, etc., não são substitutos do pai; é antes o pai que é um condensado de todas essas forças, às quais ele próprio se submete e convida seu filho a submeter-se $\mathrm{sin}^{321}$.

Tal condensação entre o poder paterno e o da instituição é bastante visível neste trecho de $A$ Metamorfose, no qual a força recobrada pelo pai parece ter uma relação direta com o uniforme que ele enverga e, indiretamente, com o trabalho simbolizado por este. A atitude do pai/empregado contra o filho inseto sem condições de trabalhar é a de puni-lo, tratá-lo com severidade extrema, transferindo a culpa pela metamorfose a Gregor:

Agora, porém ele estava muito ereto, vestido com um uniforme azul justo, de botões dourados, como usam os contínuos de instituições bancárias; sobre o colarinho alto e duro do casaco se desdobrava o forte queixo duplo; sob as sobrancelhas cerradas os olhos escuros emitiam olhares vívidos e atentos; o cabelo branco, outrora desgrenhado, estava penteado com uma risca escrupulosamente exata e luzidia. Atirou o quepe - no qual estava gravado um monograma dourado, provavelmente de um banco - até o sofá, descrevendo um arco por todo o quarto, e caminhou para Gregor, o rosto irascível, as mãos nos bolsos das calças, as abas do comprido casaco do uniforme atiradas

\footnotetext{
${ }^{320}$ BENJAMIN, p. 139
}

${ }^{321}$ K., p. 19 
para trás. Certamente ele mesmo não sabia o que estava querendo, de qualquer modo, levantava os pés a uma altura pouco comum e Gregor ficou espantado com o tamanho gigantesco das solas das botas. Mas não ficou nisso, já sabia desde o primeiro dia da sua nova vida que diante dele, o pai só considerava adequada a severidade extrema. ${ }^{322}$

Outra relação entre culpa e punição, assim como quanto à lei e a justiça, está na estranha máquina Odradek, de A Preocupação do pai de família. Indefinível por princípio, pois até mesmo a origem de seu nome é alvo de debates - se eslava ou alemã -, tudo o que sabemos é que ela existe, mesmo que não nos seja possível entendê-la. Nas palavras de Kafka, "naturalmente ninguém se ocuparia de estudos como esses se de fato não existisse um ser que se chama Odradek ${ }^{323 " . ~}$

Para Benjamin, este ser é "o mais estranho bastardo gerado pelo mundo pré-histórico com seu acasalamento com a culpa ${ }^{324 ", ~ u m ~}$ casamento que remete ao mítico, a uma história primeva da humanidade, a qual o Esclarecimento e a sociedade buscam reprimir. Odradek "se aloja, segundo os casos, em sótãos, escadas, corredores, vestíbulos ${ }^{325 ", ~ o ~}$ que na visão benjaminiana permite um paralelo com os ambientes descritos em $O$ Processo, onde o tribunal persegue a culpa.

Da mesma forma, Benjamin aponta que Odradek é o "aspecto assumido pelas coisas em estado de esquecimento 326 " - aquilo que existe,

\footnotetext{
${ }^{322}$ M., p. 32-33

${ }^{323}$ UMR, p. 43

324 BENJAMIN, p. 158. Nas correspondências entre Benjamin e Adorno, este observa que Odradek não poderia ser reduzido a tal acasalamento de forma direta. Necessariamente, operar-se-ia uma dialética entre o arcaico e a modernidade, assim como entre culpa e superação da culpa. Conforme ADORNO, se o lugar de Odradek "é junto ao chefe de família, não representaria ele precisamente a preocupação e o perigo para este último, não anteciparia ele precisamente a superação do estado de culpa da criatura, e não seria essa preocupação - um verdadeiro Heidegger posto de cabeça para cima - a cifra, a mais indubitável promessa de esperança, precisamente na superação do lar?" (ADORNO, BENJAMIN, p. 131). Da junção do pré-epocal e da culpa, surge o signo da distorção (a estranha máquina), mas também "um emblema do transcender" ( $p$. 132), do ultrapassamento do mítico e da culpa em direção a uma reconciliação entre orgânico (animal, humano) e inorgânico (máquina, razão).

${ }^{325}$ ibidem, loc. cit.

${ }^{326}$ ibidem, loc. cit.
} 
mas com suas origens já perdidas no tempo, ligadas à tradição e transmitidas pelo movimento das forças históricas. O sótão onde Odradek se aloja "é o lugar dos objetos descartados e esquecidos ${ }^{327 ", ~ o ~ l u g a r ~ o n d e ~}$ o indivíduo guarda seus fantasmas - e a sociedade suas origens.

Trata-se então de apontar de que formas a tradição sobreviveria até o presente, tendo nisso um profundo interesse histórico. "A porta da justiça é o estudo ${ }^{328 " ~ d a ~ t r a d i c ̧ a ̃ o / l e i / d i r e i t o, ~ m a s ~ B e n j a m i n ~ c o m b a t e ~ u m a ~}$ associação direta da justiça em Kafka à exegese judaica: "Kafka não se atreve a associar a esse estudo as promessas que a tradição associava aos estudos da Torá329". A justiça - representada nos investigadores, empregados, mensageiros, assistentes, nas criaturas de sua obra - não procuraria o mito, e sim o percurso da culpa. Ao buscar a sala onde deveria comparecer na Juliusstrasse no primeiro interrogatório em $O$ Processo, Josef K. "mentalmente brincava com a recordação das palavras do guarda Willem, segundo as quais a justiça era atraída pela culpa. A ser assim, a escada que por acaso escolhera iria dar, sem dúvida, à sala dos interrogatórios" ${ }^{\prime 330}$, o que realmente aconteceu.

Voltando ao caso Odradek, a preocupação do pai não parece ser em relação ao estranho ser, mas sim a respeito do que a existência deste híbrido - do qual sabemos coisas impressionantes, porém nada realmente essencial - Ihe remete: a finitude. Mesmo após a morte do pai de família, Odradek permanece, e sua existência ainda será indecifrável - como era antes.

Inutilmente eu me pergunto o que vai acontecer com ele. Será que pode morrer? Tudo que morre teve antes uma espécie de meta, um tipo de atividade e nela se desgastou; não é assim com Odradek. [...] Evidentemente ele não prejudica ninguém, mas a ideia de que ainda por cima ele deva me sobreviver me é quase dolorosa ${ }^{331}$.

${ }^{327}$ BENJAMIN, p.158

${ }^{328}$ Idem, p. 164

${ }^{329}$ Idem, p. 103

${ }^{330}$ P., p. 27

${ }^{331}$ UMR, p. 44-45. A sobrevivência de Odradek é apontada por ADORNO (2012) como um sinal da conciliação orgânico/inorgânico apontada anteriormente, assim como de uma "superação da morte" (ADORNO, BENJAMIN, p. 132). O incômodo que gera a preocupação 
Já Deleuze e Guattari verão o estranho dispositivo em formato de carretel, que ri e fala, de outra maneira: como uma "máquina abstrata (...) transcendente e reificada332", arruinada pelo tempo e hoje um destroço, mas que ainda funciona (o que não seria uma característica comum nas máquinas abstratas). A profusão dos fios soltos em Odradek, que indicariam a ruptura ou incompletude deste, parece não ser o suficiente para tornar o dispositivo inoperante. Kafka diz que "em parte alguma podem ser vistas emendas ou rupturas; (...) o todo na verdade se apresenta sem sentido, mas completo à sua maneira ${ }^{333 \prime \prime}$ esta é a descrição de Odradek ou, de certa forma, da realidade que cerca o autor? Mas esta realidade, agora, se apresenta sem uma metanarrativa que the dê coerência.

Há certa proximidade na leitura de Benjamin e de Deleuze e Guattari sobre a transcendência da culpa na obra de Kafka, mas estes interpretam esta transcendência como uma característica da lei, que não se relaciona mais com a justiça - campo do desejo ${ }^{334}$. A forma da lei não

do pai - a atemporalidade da máquina - o faz contemplar necessariamente sua dimensão orgânica.

${ }^{332}$ K. p. 125. Tal transcendência apontada por Deleuze e Guattari guarda certo paralelo com a que Adorno observa, variando apenas a questão da reconciliação entre humano e nãohumano, que não ocorre para Deleuze. Em ambas, o caráter arruinado de Odradek se destaca. Parece, assim, haver uma aproximação entre os autores sobre o potencial de ruptura contido naquilo que é colocado à margem do sistema vigente.

${ }^{333}$ UMR, p. 44

334 "Mas o caso contrário também aparece nas novelas: máquinas abstratas surgem por si mesmas e sem índices, todas montadas, mas desta vez elas não tem ou não têm mais funcionamento. Assim a máquina da Colônia Penal, que responde à Lei do velho comandante e que não sobrevive à sua própria desmontagem, ou a bobina chamada Odradek, a qual "seríamos tentados a acreditar que outrora teve uma forma útil e que agora é algo quebrado, mas isso sem dúvida seria um erro (...), o conjunto parece vazio de sentido, mas completo em seu gênero" (UMR, p. 44), ou as bolas de pingue-pongue de Blumfeld. Ora, parece que a representação da lei transcendente, com seu cortejo de culpa e de incognoscibilidade, é essa máquina abstrata. Se a máquina da Colônia Penal, como representante da lei, aparece como arcaica e ultrapassada, não é de modo algum, como frequentemente se disse, porque ali haveria uma nova lei mais moderna, mas porque a forma da lei em geral é inseparável de uma máquina abstrata autodestrutiva e que não pode desenvolver-se concretamente". (K., p. 71-72). Fica a questão, ainda em aberto, sobre qual seria a possibilidade de desenvolvimento de uma nova máquina, transcendente, para lidar com tal questão. Deleuze apostaria na própria escrita como uma possibilidade provocadora: 
pode se desenvolver de maneira concreta. No texto de Deleuze, a justiça também representada nos mesmos empregados, investigadores, serviçais, pintores - está à procura de sua libertação da culpa, pois não possui nenhuma relação com a lei: "a justiça é desejo, e não lei ${ }^{335 "}$ ". Em $O$ Processo, isso se torna mais evidente quando Josef $\mathrm{K}$. conversa com a Srta. Burstner sobre o inquérito:

- Está vendo? - disse K. - Não tem muita experiência em
questões judiciais.
- Não, não tenho - disse a senhorita Burstner -, e já o
lamentei muitas vezes, pois gostaria de saber tudo e são
justamente as questões judiciais as que mais me
interessam. O tribunal tem uma força de atração singular,
não é? ${ }^{336}$

não é mais o simbólico - a lei - que torna o real (a justiça) impossível, mas o próprio real que interdita sua possibilidade de realização. Talvez isso signifique que os agenciamentos passam a se dar segundo a lógica do simbólico e não mais em oposição a ele, ou talvez a lei (linguagem de papel, norma pseudo-transcendente) passe a ser o desejo dos agenciamentos (práticas) concretos. Se esta posição da máquina abstrata só é atingida por meio de um agenciamento específico (o de enunciação) e este revela a maquina literária como seu mecanismo, "qual é a aptidão de uma máquina literária, de um agenciamento de enunciação ou de expressão, para formar ele mesmo essa máquina abstrata enquanto campo do desejo?" (K, p. 119). Seriam estas as "condições de uma literatura menor?" (idem). A possibilidade seria a de entender a própria máquina literária do autor como o instrumento de medida de tais agenciamentos. Desta forma, o romance seria em si um agenciamento - sua referência e engajamento ao real é absoluta, e seu absurdo é a descrição quase premonitória daquilo que nos espera. Falamos de práticas que soavam como absurdas, pois o momento de sua enunciação (o ontem) não é o mesmo de sua realização (o hoje). Matar toda a metáfora, toda a significação, levando em conta questões de estilo da obra, pode implicar ser realista por meio de alegorias "literais" - e com especial crueza, como vimos: "Eis então as características novas do agenciamento maquínico romanesco, em oposição aos índices e às máquinas abstratas. Eles impõem, não uma interpretação nem uma representação social de Kafka, mas uma experimentação, um protocolo social-político. A questão torna-se: como funciona o agenciamento, já que ele funciona realmente no real?" (K, p. 73). Ou seja, como se dá a relação política (no real) deste agenciamento kafkiano (sua própria obra)?

${ }^{335}$ K., p. 74.

${ }^{336}$ P., p. 29. Há diferenças entre a tradução deste romance feita por Carone e a tradução portuguesa (feita por Gervásio Álvaro). Em especial, uma destas diferenças acaba por mostrar a presença do desejo e da libido como componentes do texto: quando a senhorita Burstner diz a K. que "A justiça tem um poder de sedução fora do vulgar, não acha?". O poder de sedução seria não apenas daqueles que executam o processo da justiça, mas a própria justiça seria sedutora. Há componentes de sedução, de desejo e de vontade (o fazer) ligados à posse e o exercício do poder. Ter poder é atrativo para quem o detêm e para quem o deseja. 
Seja o mapeamento do passado promovido por Benjamin ou a busca de intuição do futuro articulada por Deleuze, em ambos os casos tem-se uma preocupação com os efeitos da obra kafkiana no presente e no mundo onde ela está inserida, um mundo arruinado, composto por criaturas estranhas e deslocadas de onde se esperaria encontrá-las. Ou seja, um caráter político e de deslocamento. Não é possível, para ambos, separar o autor da obra, "a ferramenta do artesão, o leitor como

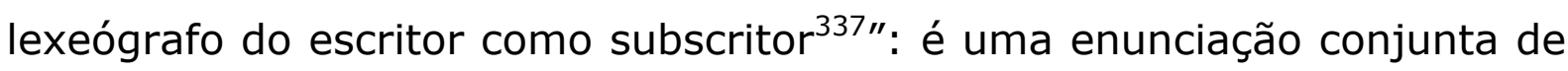
um mundo, um novo território do qual temos a intuição da existência nas brechas que surgem na aparente coesão da realidade. O esquecimento, para Benjamin, é o que deve ser combatido, e rememorar é entender o presente:

Aquilo que foi esquecido (...) nunca é algo puramente individual. (...) O esquecimento é o receptáculo a partir do qual emergem à luz do dia os contornos do inesgotável mundo intermediário nas narrativas de Kafka. "Aqui, a plenitude do mundo é considerada a única realidade" 338

Há uma relação possível entre esquecimento e a sensação de perda, a "melancólica contemplação das ruínas do passado, sem qualquer pretensão de alcançar a neutralidade de uma posição distanciada339". Da impossibilidade de alcançar esta neutralidade surge a possibilidade de transformar tal melancolia em sua superação. Memória e esquecimento são "protocolos de experiência $340 "$ do viver; o mundo intermediário é o que se encontra entre tais protocolos, entre o que ficou para trás e o que se abre para o futuro. Entre o arcaico e o contemporâneo.

\footnotetext{
337 BENSMAÏA. R, The Kafka Effect (Prefacio à edição norte-americana de K)., p. xii. A interpretação que parece mais acertada para os termos lexeograph e subscriptor constantes no original seria a seguinte, de acordo com a referência a Roland Barthes: para o primeiro, o leitor como peça fundamental na construção semântica do texto - por onde o sentido do texto emerge e, para o segundo, o autor como interessado ou leitor da própria obra.

${ }^{338}$ BENJAMIN, pp. 156-157

${ }^{339}$ KAMPFF-LAGES, p. 235

${ }^{340}$ K., p. 17
} 
A aproximação em relação a este mundo intermediário, no entanto, é diferente em cada comentador. A partir do mesmo ponto - a máquina do real em Kafka - os autores tomam vias diversas: se Benjamin vê melancolia, Deleuze realiza uma "leitura prática ${ }^{341 " ~ d a ~ o b r a, ~ u m a ~}$ experiência de vida, comédia e desejo ${ }^{342}$, ao afirmar que Kafka "é um autor que ri com profunda alegria, uma joie de vivre ${ }^{343 ":}$

Arriscamo-nos de duas maneiras a ignorar um grande autor. Por exemplo, ao desconhecer sua lógica profunda ou o caráter sistemático de sua obra. (Falamos, então, de suas "incoerências", como se elas nos dessem um prazer superior). Ou, de outro modo, ao ignorar sua potência e seu gênio cômicos, de onde a obra retira geralmente o máximo de sua eficácia anticonformista. (Preferimos falar das angústias e do aspecto trágico). Na verdade, não se pode admirar Kafka sem rirmos ao lê-lo ${ }^{344}$.

As lembranças de tempos passados evocadas em A Metamorfose, como "as conversas animadas dos velhos tempos, nas quais Gregor sempre pensava com alguma nostalgia quando, nos pequenos quartos de hotel, tinha de se atirar cansado à cama úmida ${ }^{345 ", ~ n a ̃ o ~ s a ̃ o ~ a p e n a s ~ e c o s ~}$ de um tempo no qual o problema da transformação não havia atingido o protagonista, mas funcionam como um impulso para este continuar vivendo. Gregor

às vezes pensava em reassumir os assuntos da família, exatamente como antes, na próxima vez em que a porta se abrisse; nos seus pensamentos apareceram de novo, depois de muito tempo, o chefe e o gerente, os caixeiros e os aprendizes, o contínuo tão obtuso, dois, três amigos de outras firmas, uma arrumadeira de um hotel no interior recordação agradável e passageira, - uma moça que trabalhava na caixa de uma loja de chapéus que ele tinha

\footnotetext{
${ }^{341}$ BENSMAÏA, p. xxi

342 "Ao mergulharem profundamente nos "métodos" e processos que Kafka usou para revogar o mistério da lei e relacioná-lo com seus lugares de enunciação, e os descrevendo com precisão, Deleuze e Guattari abrem caminho para - talvez pela primeira vez - uma leitura "alegre" de Kafka: uma Gaia Ciência do trabalho kafkiano". (BENSMAÏA, p. xix).

${ }^{343}$ K., p. 41

${ }^{344}$ DELEUZE, 1962, p. 3.

${ }^{345}$ M., p.34
} 
cortejado seriamente, mas devagar demais; todos eles surgiram entremeados com estranhos ou pessoas já esquecidas, mas ao invés de o ajudarem e à família, estavam sem exceção inacessíveis, e ele ficou feliz quando desapareceram ${ }^{346}$.

Mas o rebate de Benjamin às interpretações naturais e "supernaturais" da obra de Kafka também soa como uma advertência à linha de interpretação adotada por Deleuze: "É mais fácil extrair conclusões especulativas das notas póstumas de Kafka do que investigar

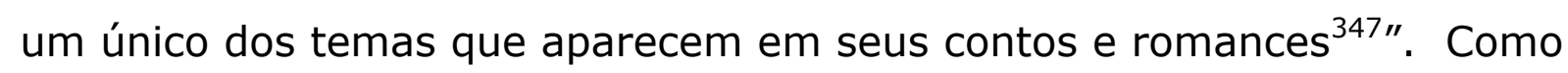
já visto, a obra é para ser tomada literalmente, sem metáforas ${ }^{348}$, ou sem a transformação destas em uma "adequação exata entre representação e realidade $349 "$.

Deleuze, mesmo se utilizando de elementos externos às obras para desmontar o funcionamento das máquinas de expressão kafkianas (elementos principalmente fornecidos por Max Brod - contestado fortemente em suas análises por Benjamin, por Adorno e pelo próprio Deleuze, que verá o biógrafo como o responsável pela inflexão da obra de Kafka em direção à teologia negativa ${ }^{350}$ - e também pela leitura dos

\footnotetext{
${ }^{346}$ M., p.36

347 BENJAMIN, p. 154. Mesmo se considerarmos que Benjamin não conhecia o teor das correspondências entre Kafka e Brod, assim como o conteúdo dos "Diários", o pensador alemão faz um chamado à sobriedade na leitura kafkiana. Benjamin irá utilizar o conceito de alegoria, um tipo de narrativa que é referente a uma coisa ou processo vivo, um relato de uma ação. Se na metáfora os significados são transferidos por meio de relações analógicas, comparativas, proporcionais, referenciais, entre outras, a composição alegórica atribui uma condição de ser normalmente imprópria à coisa à qual se refere, gerando novos objetos de significação. (cf. tópico Símbolo, Alegoria e Parábola)

${ }^{348}$ No sentido bergsoniano do termo, tão caro a Deleuze, a metáfora expressaria o conceito, porém no processo pode reduzir uma coisa a outra. "Para que a metáfora sirva como meio de aproximação direta da realidade é preciso que a imagem não cristalize um significado, mas sugira uma visão, que não é interpretação, mas contato." (SILVA, p. 97).

349 SILVA, p. 97. O deslocamento/estranhamento na forma literária, no léxico, surge exatamente pela não-correspondência entre o escrito e o real (a literalidade) que ocorre a partir do fato da linguagem ser literal em si.

350 Deleuze considera que a organização dos capítulos em O Processo, feita por Brod, nos joga na atmosfera da teologia negativa e da onipresença da ausência de Deus. Como exemplo, irá dizer (pp. 43 - 46) que a execução de K ao final do livro poderia, talvez, fazer parte de uma experiência onírica que se passaria na abertura do romance em vez de
} 
Diários do escritor), centra seu foco nos temas das obras como enunciações da coletividade. Kafka seria a voz dos judeus checos de Praga de seu tempo, uma inserção da "obra" no tecido do real" ${ }^{351}$ : "como é possível alguém alegrar-se com o mundo, a não ser quando se refugia nele?"1352

\subsection{Burocracia}

A sisudez da linguagem dos escritórios, a burocracia e o pasmo do humano frente a uma série de processos e relações de forças que para ele soam como absolutamente incompreensíveis já são, há muito, apontadas como temáticas presentes nas obras kafkianas. Essas obras, segundo LOWY, descreveriam "um mundo entregue ao absurdo, à injustiça autoritária e à mentira, um mundo sem liberdade em que a redenção

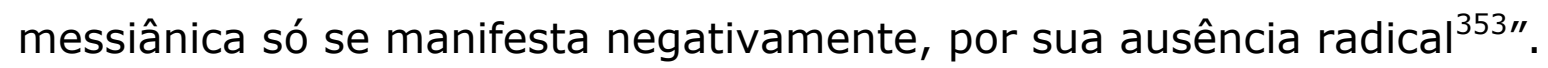

Sabendo-se que Kafka tinha uma especial afeição pelo trabalho com provérbios e frases do senso comum, levando-as ao pé da letra até que seu significado fosse totalmente reconfigurado, o monumental $O$ Processo poderia remeter ao ditado alemão: "A falta de resposta também é uma

encerrá-lo com o fecho da desesperança. Já a relação "conflituosa" entre Brod e os frankfurtianos pode ser inferida da análise feita por SANTOS de que nestes últimos "o que sobressai é o desejo de libertar Kafka de uma leitura estritamente religiosa. Nesse sentido, Benjamin foi provavelmente quem com mais veemência combateu as interpretações de Max Brod. Adorno é totalmente favorável a esse combate com Brod" (p.155)

${ }^{351}$ Como já visto, a visão de Anders sobre o conto Josefina ou O povo dos Camundongos é similar a esta abordagem deleuziana. Anders vê no conto a ineficácia da religião (e, por extensão, da tradição) como forma da preservação dos códigos do povo judeu. O narrador, um dos ratos, vocaliza o espanto, o desapontamento e a indiferença dos ratos com as habilidades da cantora. Kafka formularia assim, para ele, a posição dos judeus no mundo ou "a atitude dos judeus que não eram mais judaicos diante dos judeus judaicos" - os judeus de Praga são como um outro povo, uma coletividade imersa em um grupo majoritário.

${ }^{352}$ EFK, p. 192

${ }^{353}$ LOWY, 2005, p. 132. Tal comentário nos remete à análise de TRAGTEMBERG (2002) de que toda forma de organização social ou religiosa é erigida sobre a ideia do absurdo e tende à burocracia. $O$ papel da religião se mostraria similar ao das organizações administrativas nas quais Kafka se encontra imerso, assim como está imerso na comunidade judaica de Praga. 
resposta ${ }^{354 " . ~ J o s e f ~} \mathrm{~K}$. pergunta do que é acusado, mas principalmente quem é seu acusador ${ }^{355}$. E tais questões, os motores do romance (e que estão ligadas indelevelmente à sua frase de abertura ${ }^{356}$ ), nunca são respondidas: o máximo que se tem é a suposição de que se trata de uma calúnia, mas nem disso temos certeza. Mas a inexistência formal desta resposta não impede o desenrolar do processo, como se o silêncio e os procedimentos e informações confusas a respeito de seu trâmite funcionassem como confissão de culpa por um crime que ninguém sabe qual é.

A "confusão" é, visivelmente, uma das características que o sistema burocrático descrito no livro provoca não apenas em Josef K., mas principalmente nos leitores. Perante tal dificuldade de compreensão ${ }^{357}$, Kafka a eleva até chegar ao extremo do chiste: perante aquilo que não parece ter solução, pouco há a fazer senão rir do absurdo que se aproxima.

Em O Processo, o extremo já se insinua na própria divisão do texto: ao lermos a disposição e os nomes dos capítulos, a impressão que se tem é a de que se está a contemplar um relatório jurídico, ou uma investigação: nomes, profissões, locais, ações. Os passos da lei e do sistema. Os níveis das repartições e órgãos da máquina burocrática envolvidos em cada fase até o final/execução da sentença.

As etapas (ou instâncias jurídicas) do processo são a espinha dorsal do romance, assim como o processo em si pode ser visto como um protagonista, talvez o principal, da história. Mas é um protagonista sem

\footnotetext{
${ }^{354}$ Keine Antwort ist auch eine Antwort, no idioma original.

355 "Tiro essa conclusão do fato de ser acusado e não conseguir descobrir a mínima culpa da qual me pudessem acusar. Isso também é secundário, a questão principal é: por quem sou acusado? Que autoridade conduz o processo? Os senhores são funcionários?" (P., p.16)

356 "Alguém certamente havia caluniado Josef $\mathrm{K}$, pois uma manhã ele foi detido sem ter feito mal algum". (P., pg.7)

357 O que nos levaria novamente à presença, na temática kafkiana, do problema da incomunicabilidade e da dificuldade de entendimento, como visto em $A$ Metamorfose e $O$ Veredicto. A solução tentada por Kafka para este problema poderia ser uma recuperação da linguagem face seus lugares-comuns cotidianos, no qual o provérbio que encerraria a lição de sabedoria se encontra esvaziado de sentido na realidade, por meio de uma superconformidade/literalidade entre o enunciado e o significado?
} 
nome: descobrimos como os funcionários se chamam, mas nunca como o processo em si é nomeado, isto é, a que crime ele se refere, nem quem o atribui/imputou contra K. Uma nêmese que não se mostra, mas cuja presença é constante. Tal embate entre o indivíduo e a estrutura permite considerarmos que um dos temas centrais de $O$ Processo é "o funcionamento de uma hipócrita máquina burocrática na qual o herói foi

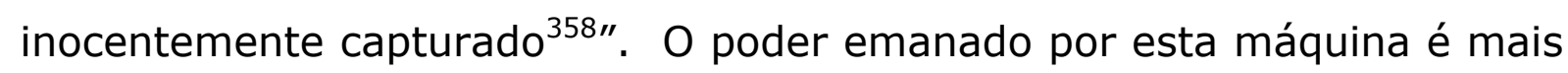
tirânico do que o concentrado na figura de um ditador, por exemplo, exatamente por não ter rosto ou nome, por ser um sistema que funciona independentemente de quem seja o nome ou rosto que, simbolicamente, o comandaria. Onde o processo em si é mais importante do que os seres envolvidos em seu desenrolar ${ }^{359}$. Para Kafka, "as cadeias da humanidade torturada são feitas de papel de escritório $360 "$ ".

A relação entre o homem e as figuras de autoridade condensadas na burocracia, no pai ou na religião, guardariam em si a dualidade entre a alienação e a busca pela liberdade. Ao mesmo tempo em que, em $O$ Castelo, K. tenta de todas as formas contato com Klamm para receber as instruções para a execução de seu trabalho, a negativa do contratante coloca o protagonista em uma situação verdadeiramente alienada, de anulação da personalidade individual: o que o definiria naquela comunidade onde é o recém-chegado é o fato de ser o agrimensor, mas ele acaba sendo contratado para não fazer aquilo a que teoricamente teria

\footnotetext{
${ }^{358}$ ARENDT apud LOWY, 2005, p. 110

${ }^{359}$ Tanto Horkheimer/Adorno como Deleuze observam a existência de processos sociais nos quais isto ocorre, variando apenas as nomenclaturas usadas pelos frankfurtianos em relação ao filósofo francês (sociedade administrada e sociedades de controle). A dita "mentalidade do engenheiro" que caracteriza a razão instrumental coloca o engenho, o processo, a forma de fazer como aquilo ao qual o ser humano deve se adaptar. Desta forma, o papel da técnica se inverte: em vez de conjunto de procedimentos e ações com as quais o ser humano transforma o mundo, torna-se um sistema ao qual quem deve se adaptar é o próprio humano, o que se estende ao tecido social como um todo. A sociedade passa a ser gerida como uma empresa, ou mais precisamente, como uma linha de produção na qual o produto são os próprios indivíduos; que se modifica de acordo com a demanda do capital e as mudanças nos modos de produção.

360 KAFKA apud LOWY, 2005, pp.13 et seq. Este comenta que tal imagem "sugere, ao mesmo tempo o caráter opressivo do sistema burocrático, que subjuga os indivíduos com seus documentos oficiais, e o caráter precário das cadeias, que facilmente poderiam ser rompidas se os homens quisessem libertar-se delas" (p. 15)
} 
sido chamado. Para não ser o que é: "não tenho relação com os camponeses nem pertenço ao castelo ${ }^{361 " \text {. }}$

Uma das reações de K., investindo na sedução de Frieda (conhecida por ser amante de Klamm) pode ser vista como uma forma de readquirir certo controle da situação e de si, pois paira a dúvida se a moça não seria apenas um joguete para uma audiência com ele. Com a exceção de Amália, todas as figuras de autoridade têm consigo a submissão quase voluntária das pessoas do vilarejo. Para K., subverter esta cadeia de poder no vilarejo adquire uma função emancipatória, mesmo que ao final ele não seja visivelmente bem-sucedido no processo ${ }^{362}$.

A burocracia do mundo retratado se faz acompanhar por uma obediência tácita a ela: vivemos em um mundo no qual a autoridade é vista como natural e a adaptação à ordem é um comportamento elogiável e aconselhado em todos os momentos, efetuado até mesmo por aqueles que em tese deveriam criticá-lo, ao ponto em que desaparecem as distinções entre as esferas pessoal e oficial: onde termina o K. agrimensor e começa o indivíduo K.?

E o que era ali, na realidade, aquela outra vida? Em lugar nenhum K. tinha visto antes, como ali, as funções administrativas e a vida tão entrelaçadas - de tal maneira entrelaçadas que às vezes podia parecer que a função oficial e a vida tinham trocado de lugar. O que significava, por exemplo, o poder até agora apenas formal que Klamm

\footnotetext{
${ }^{361}$ C., p. 8

362 LOWY (2005, passim) considera que O Castelo se refere, mesmo que de forma indireta, às insurreições na Europa entre 1818 e 1922, o que colocaria a obra dentro de uma temática de resistência ao poder, ainda que uma resistência individual, como Amália, ou uma busca de sentido da estrutura deste poder, como o próprio $\mathrm{K}$. O fato do livro terminar "no ar", no meio de uma frase, não soluciona a situação, o que para alguns seria a indicação de que o terror burocrático não teria saídas, assim como o final de O Processo sugere. Ou isso pode ser visto como uma saída em aberto. Para ele, uma das temáticas da obra de Kafka é a liberdade, e que seus escritos possuem forte viés antiautoritário, chegando às raias do anarquismo (o que explicaria a famosa citação "Não esquecer de Kropotkin"). Este não aparece enquanto doutrina política, mas na forma "de um estado de espírito e de uma sensibilidade crítica - cuja principal arma é a ironia, o humor" (p. 57). Mas nem por isso a obra pode ser reduzida a esta característica. "Kafka estava longe de ser um "anarquista", mas o antiautoritarismo - de origem romântica e libertária - atravessa o conjunto de sua obra romântica e libertária, num movimento de universalização e de abstração crescente do poder da autoridade paterna e pessoal até a autoridade administrativa e anônima" (p. 59).
} 
exercia sobre o ofício de K.. comparado com o poder que Klamm tinha em toda a sua efetividade no quarto de dormir de K. $?^{363}$

Analogamente, uma peça como Josefina, considerada como portadora de uma temática crítica religiosa ${ }^{364}$, pode ser vista como uma ácida comparação das relações que sustentam a burocracia. Comparativamente, se a ratinha supõe proteger o povo, mas é protegida por ele e é mantida nesta ilusão, são as tradições e as inter-relações humanas que acabam por dar a forma e a força à estrutura burocrática que surge aparentemente para a defesa dos componentes do grupo, mas que é ineficaz nesta tarefa. Esta estrutura também acaba sendo mantida, a despeito de sua exemplar inoperância. Vejamos que a ratinha reclama de qualquer quebra no padrão de seus espetáculos: um estado jurídico/burocrático é especialmente afeito a seus rituais.

A autoridade religiosa também é um corpus burocrático: mandamentos são regras de conduta de uma sociedade. Desrespeitá-las significa atrair a ira do socius, que insufla ódio pela diferença e impõe o silêncio e a resignação ${ }^{365}$. A voz débil consegue, mesmo assim, calar.

\footnotetext{
${ }^{363}$ C., p. 43. Para LOWY (2005), esta sensação de falta de limite entre o oficial e o individual é a expressão mais clara do termo "kafkiano", que significaria "um aspecto da realidade que as ciências sociais tendem a ignorar e para o qual não têm qualquer conceito pertinente: a opressão e o absurdo da reificação burocrática tal como são vividos pelas pessoas comuns" (pp. 204-205).

${ }^{364}$ Para ANDERS (2007), este conto "apresenta inequivocamente a religião judaica como um incidente na história do povo judeu" (p.126), como já visto.

${ }^{365}$ A religião acabaria por assumir um papel contratualista na relação entre as pessoas. Para Adorno e Horkheimer, os princípios ético-reflexivos do judaísmo e das demais religiões antigas se encontram entranhados no socius que suporta tais modelos de crença, ordenando a vida do grupo que os adota. Tal relação se quebra com a ascensão do cristianismo, que separa César (a lei, o estado, a organização do império romano, até mesmo nas moedas cunhadas com o rosto do govenante) de Deus (o transcendente e atemporal). "A transformação do ritual pagão do sacrifício não se consumou apenas no culto, nem apenas na mente, pois ela também determinava a forma do processo de trabalho" (DE, p.166). Por extensão, determina a forma das relações que constituem a sociedade, onde o "sacrifício" é necessário para a manutenção e funcionamento do organismo/sistema como um todo: os finais de O Processo e Na Colônia Penal são instrutivos neste sentido. O monstro burocrático nos remeteria, então, a uma visão weberiana da organização social por parte de Kafka?
} 
Ela tem só desprezo por aqueles que têm opinião contrária à sua - e provavelmente um ódio não confessado [...] a arte dela nos faz bem e quando nos sentimos bem, assobiamos; mas sua audiência não assobia, nela nem um rato bole, como se participássemos todos da paz almejada, da qual nosso próprio assobio no mínimo nos aparta - e por isso silenciamos. É seu canto o que nos enleva ou a quietude solene que envolve a fraca vozinha ${ }^{366}$ ?

Persiste a dúvida sobre a razão pela qual a audiência (comunidade) se deixa levar por tão débil canto, mas esta razão parece residir em uma autoridade que se transformou em necessidade: criou-se dependência de um sistema que se passa por "salvador a posteriori deste povo367", o que, apesar de inverossímil e sabido por todos, é aceito sem muita hesitação.

As regras de casa também representam uma modalidade de burocracia, como pode ser visto em $O$ Veredicto e também na famosa Carta ao Pai. No primeiro, o fluxo epistolar entre Georg e seu amigo pode ser visto de forma análoga à troca de memorandos, principalmente porque o pai era o "representante [do amigo] aqui no lugar ${ }^{368 " ~ e ~ o ~ a m i g o ~}$ realiza um procedimento que é descrito de forma quase cartorial para se informar do que acontece, pois, segundo seu representante, ele

sabe de tudo cem vezes mais do que você [Georg] mesmo, amassa sem abrir as suas cartas na mão esquerda enquanto com a direita segura as minhas diante dos olhos para ler ${ }^{369}$.

Ao final, a sentença proferida pelo pai-juiz e cumprida à risca por Georg acaba por apresentar a face bizarra da autoridade $^{370}$ : a nãoliberdade, pois o uso do poder se dá sem propósito ou justificativa e o cumprimento estrito da ordem denuncia seu absurdo. De igual teor é a

\footnotetext{
${ }^{366}$ AF/C, pp. $40-41$

${ }^{367}$ AF/C, p. 46

${ }^{368}$ EFK, p. 40

369 ibidem, p.41

${ }^{370}$ A relação figura paterna-figura burocrata também é assumida como possível por Deleuze e por Benjamin, conforme visto no tópico 5.1.
} 
opressão do pai de Kafka sobre este, mesmo sendo de ordem psíquica e não física. A descrição minuciosa dos "recursos educativos ${ }^{371 " ~ e m p r e g a d o s ~}$ pelo velho Hermann na educação de seu filho Franz encontram paralelos nos procedimentos detalhados para o cumprimento das sentenças em $\mathrm{Na}$ Colônia Penal: se a máquina interioriza no condenado a ordem do sistema, aniquilando-o em todos os níveis, o exercício da autoridade de forma tão ostensiva por parte do pai interioriza nos irmãos e no próprio Franz o modelo a ser seguido, como um manual de procedimentos ${ }^{372}$.

Nesses momentos, portanto, a crítica kafkiana opera como uma possibilidade de resistir, de não se submeter. Para tal, é preciso compreender como funcionam, mas principalmente como fracassam, os mecanismos de submissão. A exemplar ineficiência da máquina da burocracia/lei/autoridade (destruída em Na Colônia Penal, ridicularizada em O Processo, enfrentada na Carta ao Pai, entre todos os exemplos já elencados) aponta para uma situação de crise do modelo ao qual ela se remete. A estrutura só é risível e motivo de chacota porque o modelo que Ihe daria suporte já não existe mais, fazendo com que ela perca o sentido, deixando o processo burocrático com seu significado encerrado em si mesmo e a lei como pura forma vazia, sem conteúdo ${ }^{373}$.

De certa forma, a insuficiência deste modelo antevê um momento no qual a compreensão que temos do processo civilizatório - ou do modelo de sociedade existente até então, influenciada pelos ideais iluministas não seria mais capaz de dar sentido à existência. O tecido social onde e sobre o qual Kafka escreve já mostra os sinais daquilo que Deleuze chamará de "potências diabólicas que batem à porta: fascismo, estalinismo e americanismo ${ }^{374 "}$.

\footnotetext{
${ }^{371} \mathrm{CP}, \mathrm{p} .13$

${ }^{372}$ A interiorização de procedimentos nos "próprios corpos" em Na Colônia Penal permite o estabelecimento com os conceitos de disciplina e "corpos dóceis" conforme descritos por FOUCAULT (2007).

${ }^{373}$ Para Deleuze, Kafka entenderá que da relação entre a máquina da lei e a prática de justiça é que surge a relação de poder: da assincronia entre um código permanentemente anacrônico e as práticas diárias, o desejo de justiça, do certo e do errado. Lei e culpa se inter-relacionam, assim como justiça e desejo - uma diferença entre normatização e prática. ${ }^{374}$ K., p. 41
} 
Se isso for observado pelo prisma da relação entre indivíduo e sociedade - sua inserção direta no mundo e as relações estabelecidas a partir disso - a falência do modelo abriria espaço tanto para a irrupção de formas mais livres de associações ou mais igualitárias do ponto de vista da justiça como também para as formas mais temíveis de opressão do indivíduo, em que a lei - linguagem de papel que versa sobre a sociedade - passa a ser o ponto de referência do tecido social e das interações humanas, sobrepondo-se de certa forma a estas.

Porém, a insuficiência dos procedimentos jurídico-burocráticos como campo de regulação social - e o absurdo dos intermináveis escritórios, tribunais e instâncias de julgamento (ao ponto em que podemos interpretar em certas horas o romance $O$ Processo como as atas de um processo ou como o processo social que mostra tal ineficácia) mostra que aqui há uma clara oposição entre o modelo e a realidade: a burocracia (transcendente) e a vida (imanente) não se relacionam mais, ou nunca se relacionaram, pois pertencem a mundos diferentes e que se encontram em mutação. Surgiria, dentro da obra kafkiana, uma busca por liberdade que

não aparece como tal em lugar nenhum em seus romances e contos: ela existe somente em negativo, como crítica de um mundo totalmente desprovido de liberdade, submetido à lógica absurda e arbitrária de um "aparelho" todopoderoso ${ }^{375}$.

Assiste-se, então, a um embate entre o você deve - a representação da norma, materializada na lei e na burocracia - e o eu quero - a expressão da vontade e do desejo pessoais: o personagem $\mathrm{K}$. vive dentro do mundo burocratizado (que opõe regra e desejo), saindo de uma situação de oposição entre lei e vontade (espírito/corpo; processo/processado) para a onipresença de um desejo, de uma ação, que mesmo não explicitados se encontram vivamente presentes.

${ }^{375}$ LOWY, 2005, p. 56 
Mas na obra de Kafka não há uma questão hierárquica envolvida apenas nas relações entre o protagonista e o aparelho. As formas de organização social, de maneira geral, mostram-se entremeadas pelas relações de poder dos indivíduos que as compõem. O desejo de agir, como constitutivo do indivíduo, faz parte do mundo na medida em que o indivíduo participa do socius. O poder não é exclusivo da subjetividade, mas surge como fruto das relações entre indivíduo e tecido social.

Aquilo que denominamos como poder acaba por desenvolver desdobramentos e tentáculos eficazes para a sustentação de estruturas hierárquicas (ou administrativas) incoerentes, que acabam sendo utilizadas em benefício de alguns.

Para isso, as relações humanas são uma ferramenta especialmente eficaz: não apenas a relação entre Frieda e K, como a entre Leni e Josef K., dentre outras na obra kafkiana, podem ser consideradas relações-fim, segundo as quais o envolvimento entre os personagens é pautado por um objetivo específico dentro das estruturas de poder. Relações burocráticas, pois ocorrem dentro do próprio organismo do poder: se o processo é o próprio romance em si, tudo que ocorre ali se dá dentro das malhas da lei e da ordem. Norma e libido, devidamente plasmadas ${ }^{376}$.

${ }^{376}$ A ideia de que a burocratização da sociedade é uma forma de lidar com o impulso do Eros, o desejo, nos remete já ao conceito freudiano do direcionamento da pulsão para o trabalho e ecoa nas análises tanto de Adorno como de Deleuze, inclusive em seus textos sobre Kafka. Em Adorno, tanto a análise da mímesis como a da pulsão, ou a "tendência inerente a todo ser humano de retorno a uma situação anterior" abordam tal problemática. Para Adorno, "Inicialmente, em sua fase mágica, a civilização havia substituído a adaptação orgânica ao outro, isto é, o comportamento propriamente mimético, pela manipulação organizada da mimese e, por fim, na fase histórica, pela práxis racional, isto é, pelo trabalho." (DE., p. 168). A dominação do Eros ocasiona aquilo que é chamado por Adorno de domínio "crispado" do homem sobre a natureza. Se o projeto de racionalidade iluminista passa pelo domínio deste medo via trabalho e reflexão, mas não o elimina completamente, o medo reaparece na própria proibição ao medo: a racionalidade dirigida a fins surge como forma de disciplina contra a própria razão e a possibilidade de reconhecimento do outro, pois haveria sempre um resíduo do qual a normatização acabaria por não dar conta. A burocracia, como elenco de códigos normatizadores da sociedade, operaria como uma tentativa constante de formatação social a um ponto no qual os próprios integrantes da sociedade cuidam de eliminar a diferença, buscando homogeneidade e a realização da ideologia na qual se inserem, acaba por operar em dois circuitos: catarse (pulsão de morte irracional) e a manutenção do status quo (razão dirigida a fins e como um instrumento de dominação). "O rigor com que os dominadores impediram no curso dos séculos a seus próprios descendentes, bem como às massas dominadas, a recaída em modos de viver 
K. abriu o livro de cima da pilha e apareceu uma gravura obscena. Um homem e uma mulher estavam sentados nus num canapé; a intenção vulgar do desenhista era claramente discernível, mas sua inabilidade tinha sido tão grande, que afinal podiam ser vistos apenas um homem e

miméticos - começando pela proibição social dos atores e dos ciganos e chegando, enfim, a uma pedagogia que desacostuma as crianças de serem infantis - é a própria condição da civilização. A educação social e individual reforça nos homens seu comportamento objetivo como trabalhadores e impede-os de se perderem nas flutuações da natureza ambiente. Toda diversão, todo abandono tem algo de mimetismo. Foi enrijecendo contra isso que o ego se forjou." (DE., p. 169). O sujeito que desenvolve uma conduta que se assujeite ao pensamento e à prática totalitária é levado a tal por um mecanismo de projeção reversa, "o reverso da mimese genuína, profundamente aparentada à mimese que foi recalcada, talvez o traço caracterial patológico em que esta se sedimenta. Só a mimese se torna semelhante ao mundo ambiente, a falsa projeção torna o mundo ambiente semelhante a ela" (DE., $p$. 174). A falsa projeção está na categoria do recalque: a interdição do reconhecimento do outro e do processo mimético tem, como contrapartida, a ilusão de controle e de conformação do mundo ao Eu, fazendo o indivíduo ignorar completamente as relações estruturais presentes no corpus social e produzir uma falsa segurança de si e para si. A negação da mimese e dos impulsos do id acaba por fazer o indivíduo projetá-los como características do objeto de cobiça ou ódio, por exemplo. A confusão se forma pelo fato de que, a partir de um determinado ponto, é impossível determinar o que é projeção e o que é intrínseco ao objeto. Mas tal resíduo do Eros acaba por aparecer dentro do próprio sistema. O Eros reprimido e recalcado acaba por encontrar uma expressão nos próprios elementos que simbolizam tal recalque: Adorno notará o caráter erótico existente, por exemplo, na repetição de gestos e na disciplina extrema (no exemplo do oficial nazista nos Elementos do Antissemitismo), ao ponto de sugerir uma relação direta entre autoritarismo e repressão sexual. Em Deleuze, o Eros jurídico-burocrático surge não como uma repressão do impulso libidinal, mas como efeito positivo de sua existência: "Onde se acreditava que havia lei, há de fato desejo e apenas desejo. A justiça é desejo e não lei. (...) Se todo mundo pertence à justiça, se todo mundo é seu auxiliar, do padre às mocinhas, não é em virtude da transcendência da lei, mas da imanência do desejo." (K., p.74 e p.76). O desejo é o que cria/produz a estrutura, não o que é reprimido por ela. Em Kafka, o desejo - a relação com o feminino não é, no caso, uma busca pela mãe ou musa inspiradora - seria uma fonte de "força física para escrever" (K., p. 47). No caso do romance, a exposição e mapeamento do Eros burocrático, policial, judiciário, econômico ou político, ou a construção de uma nova forma de entendimento da relação entre lei/sistema e os agenciamentos de desejo, ou entre querer e poder realizar. A análise deste autor sobre Sacher-Masoch e o caráter contratual do chamado masoquismo (que envolve palavras-chave, combinações de limites, aceitação e transferências de objetos, logo sujeito a regras e leis como um Eros burocrático exige e condiciona ao mesmo tempo que gera novas regras para tal) reforça esta abordagem. Somos máquinas desejantes, estabelecemos agenciamentos-associações e relações de acordo com o objetivo de satisfazer a tensão que nos impele a um fim. Inoculamos o produzir no que produzimos: a obra literária, na visão de Deleuze, não é apenas o livro - o próprio ato de sua confecção passa a ser um constitutivo de seu significado. Em Kafka a produção seria uma forma de lidar com a tensão de seus relacionamentos e seu medo do casamento. Com certa ironia, pode-se sugerir aqui um mecanismo freudiano de direcionamento da pulsão em direção ao trabalho em busca de novas linhas de ação, intensidades ou velocidades; para ORLANDI (1995), "com a concepção produtivista do desejo, Deleuze e Guattari operam uma transposição do conceito de pulsão para o de máquina desejante" (p. 178 apud ARAGON, 2006, p.18). Parafraseando a frase de Henry Kissinger, no caso do Eros burocrático, "o poder é o afrodisíaco mais forte". 
uma mulher que sobressaíam da gravura com uma corporeidade excessiva, sentados os dois em posição demasiado ereta e, em consequência da falsa perspectiva, só se voltavam um para o outro com dificuldade. K. não continuou a folhear, abriu somente a página de rosto do segundo livro; era um romance com o título: Os tormentos que Grete teve de sofrer com seu marido Hans.

- São estes os códigos de lei estudados aqui - disse K. -, é por homens assim que devo ser julgado ${ }^{377}$.

\subsection{O caso K: estranhamento e arte política}

A priori, antes de suas obras, a arte é uma crítica da feroz seriedade que a realidade impõe sobre os seres humanos ${ }^{378}$

Toda ação humana envolve, mesmo que de forma implícita, a presença/existência de um outro, ou de uma coletividade, uma polis. As relações entre as pessoas, desta maneira, podem ser entendidas como políticas pois ocorrem dentro de um tecido social que lhes dá suporte. Qualquer inter-relação entre o ser e a realidade (sejam outros seres ou o espaço que os abriga) é um ato político, seja em escala macro ou micro. Toda ação é uma ação política. A vida é política em sua totalidade ${ }^{379}$.

\footnotetext{
${ }^{377}$ P., p. 53. A interessante referência que Kafka faz ao nome de uma de suas personagens mais famosas, a irmã de Gregor, faz com que imaginemos o que possa ter acontecido após o final de A Metamorfose. A relação de Gregor e Grete também é, como já visto, contaminada pela tensão libido-autoridade, naquilo que Deleuze chama de "incesto esquizo" e que, ao não se concretizar, dispara a ira de Grete (será a mesma que sofre com Hans?): "No fundo, é o que a irmã não tolera. Ela aceitava Gregor, queria como ele o incesto esquizo, o incesto de fortes conexões, o incesto com a irmã que se opõe ao incesto edipiano, o incesto que testemunha uma sexualidade não humana como um devir animal. No entanto, ciumenta do retrato, ela passa a odiar Gregor e o condena. A partir daí a desterritorialização de Gregor em seu tornar-se animal fracassa: ele se faz reedipianizar pelo lançamento da maçã, e só resta morrer, maçã incrustada nas costas." (K., p.23)

378 TE, p. 13

379 "Toda sociedade, mas também todo indivíduo, são pois atravessados pelas duas segmentaridades ao mesmo tempo: uma molar e outra molecular", sendo que "sempre uma pressupõe a outra. Em suma, tudo é político, mas toda política é ao mesmo tempo macropolítica e micropolítica" (MP, p.90)
} 
Como exemplo, o mundo da burocracia está presente na vida de Kafka, assim como também está presente na obra do escritor ${ }^{380}$. Mais do que simplesmente descrever em seus textos o dia-a-dia das repartições ou dar à obra um caráter confessional, Kafka usa a burocracia como elemento operante na obra e como indicativo das relações humanas, que se mostram mediadas pelo aparato de leis e normas. Uma imbricação entre um modelo social ou sócio-político, visto que a existência de uma estrutura organizacional jurídica pressupõe a existência de um sistema de forças e relações de conquista e manutenção de poder ${ }^{381}$, e as relações de autoridade, digamos, na vida privada ${ }^{382}$, alteradas pelas estruturas mas também alteradoras destas estruturas.

Ainda que não de forma explícita, ou atrelada a uma ideologia, a obra de Kafka se torna política exatamente pela temática abordada e pela forma que tal temática se apresenta na estrutura da própria obra. Para muitos, Kafka é considerado um realista, mesmo que tal realismo se mostre por meio de imagens que não parecem ter ligação com a realidade. Ou seja, sua obra realizaria uma abordagem objetiva da realidade, estaria engajada neste real.

\footnotetext{
${ }^{380}$ Constituindo-se, de certa forma, em um plano de imanência da obra kafkiana. Burocracia e política são terrenos imbricados. KORFMANN (2009, passim) levanta uma hipótese bastante plausível que relaciona a simpatia de Kafka pelo pensamento de esquerda a seu trabalho como funcionário público: Kafka fez carreira como funcionário público na Arbeiter Unfall- Versicherungs - Anstalt, chegando a uma posição gerencial intermediária. Além disso, produziu "artigos especializados sobre sua área, que deviam classificar empresas industriais quanto a seu grau de perigo para a saúde dos trabalhadores. Para uma compreensão melhor de processos industriais, frequentou cursos sobre tecnologia mecânica na Universidade de Praga e visitava regularmente as fábricas, onde via de perto os danos físicos causados pelas máquinas, descrevendo as consequências em textos ilustrados". Como via os efeitos da mecanização nos indivíduos, inclusive descrevendo amputações e episódios de invalidez de trabalhadores em tais papers, aproximou-se do pensamento próproletariado.

381 Emprestando tal definição de política do pensamento de Maquiavel. O poder dos funcionários da Justiça sobre os destinos de Josef K., assim como o poder de Klamm sobre o agrimensor, deriva de suas posições dentro deste socius narrado por Kafka.

382 O que já foi tratado, ainda que de forma incompleta, no tópico sobre a burocracia, e que é visível em diversos relacionamentos dos personagens dos contos e romances. Avançando neste paralelo em direção à vida pessoal de Kafka e sua imbricação com sua obra, a Carta ao Pai se torna eminentemente política, visto que não se esgota na relação edípica, mas aponta para um conflito de gerações ou de autoridades, resultante de diferentes visões de mundo. Retorna-se aqui ao conceito de menor, ou revolucionário, em Deleuze: a expressão de uma diferença frente a um padrão dominante.
} 
O objeto a ser pensado, então, não é a busca por um posicionamento político-ideológico panfletário na obra kafkiana, mas entender como a questão política pode ser um dos componentes em sua própria elaboração e quais características desta obra provocariam tal efeito.

O estranhamento é uma política da obra kafkiana, um modo de agir por meio da escrita que visa comunicar uma mensagem, assim como provocar um efeito específico e intencional sobre o receptor de tal mensagem ${ }^{383}$. Conforme já visto no decorrer deste trabalho, o próprio autor via tal provocação, tal situação de deslocamento/"desloucamento", como uma ação calculada em seu texto ${ }^{384}$. Tal ação possui um caráter político, de acordo com a definição usada para este termo - que agora abrange todo o processo da existência. Qual seria então a interpretação política possível para o estranhamento na obra de Kafka?

A não-familiaridade a partir do familiar, ou a sensação de ser um estranho em sua própria terra, coloca a realidade sob suspeita. "Kafka deslouca a aparência aparentemente normal do nosso mundo louco, para

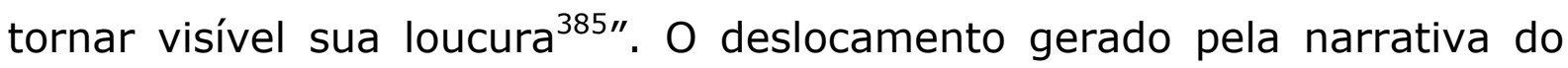
autor checo nos remete ao pensamento de Adorno sobre a imbricação entre a forma-conteúdo da obra de arte e o mundo que a suporta, não sendo possível abdicarmos de um polo em benefício do outro; a fratura do texto (presente desde a economia da linguagem até a passagem entre

\footnotetext{
${ }^{383}$ Pode-se, a partir desta observação sobre Kafka, apontar a existência de uma economia politica da literatura: as regras internas da obra, regras de ação narrativa que conduzem os modos de ação e de relação autor-texto-leitor, mediando seus efeitos e impactos.

${ }^{384}$ Cf. nota 188: a escrita como o machado que rompe o mar de gelo que há nas pessoas e em cada indivíduo. Carone observa que, em $A$ Metamorfose, a precisão da expressão ungeheueres Ungeziefer (inseto monstruoso) mostra o cuidado de Kafka com a linguagem e com aquilo a ser transmitido. Como etimologista amador, o autor checo saberia exatamente o efeito da repetição do prefixo un (que cria uma atmosfera negativa para o desenrolar da novela), assim como o da escolha da palavra ungeheuer, que etimologicamente significa "aquilo que não é mais familiar", ou seja, estranho, opondo-se a geheuer, ou familiar. Interessante observar que tal palavra acaba por ter significado muito próximo - se não igual - à relação unheimlich/heimlich, que também designam o estranho e o familiar.

${ }^{385}$ ANDERS, 2007, p. 15
} 
situações aparentemente inconciliáveis) indicia ${ }^{386}$ - pois não se trata de apenas alegorizar - os contrastes e contradições da realidade: "Ele [Kafka] é o criptograma da fase final e resplandecente do capitalismo, que Kafka excluiu para determiná-la mais precisamente em sua negatividade" ${ }^{\prime 387}$.

A obra de arte acaba por assumir o papel do negativo em relação à realidade na qual foi engendrada, abrindo um campo que pode ser reconhecido como uma alteridade a esta realidade. Mas uma alteridade que contém em si os elementos da própria realidade geradora. Assim, a relação entre arte e sociedade não é mediada, e sim direta. Para COHN,

os componentes fundamentais do processo histórico-social no interior do qual a obra é produzida estão incorporados nela, na forma da obra. Adorno não vai procurar elos intermediários entre a música de Beethoven e a sociedade europeia pós-revolucionária e napoleônica. Vai procurar a marca dessa sociedade na tessitura das obras mesmas, nos problemas que o compositor enfrentou para dar conta do material - ou seja, do conjunto de elementos técnicos e construtivos historicamente constituídos de que dispunha - e nas soluções encontradas na efetuação da lógica interna da lei formal - na composição de uma sinfonia, por exemplo. ${ }^{388}$

O mundo onde a obra de Kafka surge já é um mundo em transformação, onde as contradições que desenham o presente estão

\footnotetext{
${ }^{386}$ Em Semiótica, o Índice é um signo que situa o fato, o indicando no espaço e no tempo. É quando o significante remete ao significado tomando como base a experiência vivenciada pelo interpretante (PEIRCE, apud CARDOSO, M. 2012, p.166). Por exemplo, ao ver uma imagem de um carro sem a maçaneta, estando apenas um buraco no seu lugar, isto é um índice de uma tentativa de assalto. Mas isso só se torna evidente porque temos experiências anteriores com assaltos, seja através de experiências pessoais, seja por reportagens vistas no telejornal diário. Para Peirce, o índice opera pela conexão de contiguidade de fato entre dois elementos, porém não de forma alegórica mas referencial: o que é próximo ao fato remete a ele, mas não o cita diretamente nem o narra de forma pictórica. Utilizamos a palavra indiciar para se referir a este processo pois a raiz indício possui o significado de "sinal ou fato que deixa entrever alguma coisa, sem a descobrir completamente, mas constituindo princípio de prova" (Dicionário MICHAELIS online). Kafka não acusa a realidade de ser caótica, mas aponta os indícios disso.

${ }^{387}$ AsK, p. 252

${ }^{388}$ COHN, 1986, p.20
} 
também indiciadas na obra: as estruturas que cercam o indivíduo e a relação entre desejo, sublimação e ato na construção do eu social - o que caracteriza a inserção do indivíduo na sociedade, esta um constructo no qual os signos do capital se transformam no modo de vida e nos códigos culturais que unem a coletividade.

A Metamorfose nos traz uma possibilidade interessante de análise nesse sentido: Gregor, o arrimo da família, está em um ponto de sua carreira no qual já não é um simples trabalhador braçal, mas não chegará a uma posição de chefia - até mesmo pelo fato de ser um profissional relativamente autônomo pertencente à pequena burguesia ${ }^{389}$. A transformação em inseto traz, em primeiro lugar, a preocupação com a relação de trabalho e com possíveis punições por parte do chefe, com a consequente decadência financeira que isso pode trazer à família, devedora ainda por "cinco ou seis anos"390". Mas também é um obstáculo ao desejo de liberdade de Samsa, pois não conseguir quitar o débito significa a permanência do estado de coisas. Se a transformação em inseto é uma prisão para o corpo, impossibilitado de trabalhar, e da mente, incapaz de sair do pensamento à prática, a manutenção da humanidade de Gregor seria a sua própria prisão dentro do sistema ${ }^{391}$.

${ }^{389}$ Em alguns dos principais textos de Kafka, os protagonistas parecem se encontrar dentro
de um estrato social caracterizado por certa autonomia em relação ao trabalho braçal, mas
nunca em posições de real destaque na cadeia de produção e valor. Exemplos: o médico da
província; o agrimensor K., contratado por empreitada; o caixeiro-viajante Samsa; Josef K,,
o bancário; a família de comerciantes em O Veredicto. O tecido social abordado parece ser
o que Marx chama de pequena burguesia, a popular classe média, ou mediana como seus
personagens; uma literatura de uma burguesia decadente.
390 EFK, p. 228. A dívida é vista por Gregor como aquilo que o impede de declarar sua
independência do trabalho que o extenua: a dívida dos pais é um tipo de prisão para o filho.
Além das implicações óbvias relacionadas à tradição judaica, ao pecado e à psicologia, tal
questão pode ser vista como uma referência à perda de identidade do ser dentro do socius,
assim como do peso das relações econômicas normatizando as ações e os vínculos
familiares (a micropolítica da família).
391 Conforme Adorno, em Kafka "a origem social do indivíduo revela-se no final como a força
que o aniquila" (apud CARONE, p.224). Pode-se entender tal origem social como a família,
pela interpretação de Carone, que realiza uma inversão da figura de Gregor: de parasitado a
parasita da família, aquele que impede que as potencialidades surjam e que obriga a todos
na casa a ajustarem sua vida ao problema do filho-inseto, que agora nem mesmo colabora
para a renda da casa. Mas também é possível ver tal "origem" como um indicativo das
relações de trabalho e da problemática do sujeito: o indivíduo preso às engrenagens do
sistema, que o define como homo oeconomicus e que forma suas noções de personalidade. 
Já em $O$ Processo temos outro tipo de relação política: indivíduo versus aparato de Estado, ou a ausência da liberdade mesmo quando ela aparenta ainda existir. Quando Josef K. vai procurar Titorelli, este diz que nunca presenciou algum caso no qual o acusado fosse absolvido.

Esqueci de the perguntar primeiro que tipo de libertação deseja. Existem três possibilidades, ou seja, a absolvição real, a absolvição aparente e o processo atrasado. Naturalmente o melhor é a absolvição real, só que não tenho a mínima influência sobre esse tipo de solução. Na minha opinião, não existe nenhuma pessoa que pudesse ter influência sobre a absolvição real. Provavelmente, aqui decide apenas a inocência do acusado. Uma vez que o senhor é inocente, seria de fato possível que confiasse apenas na sua inocência. Mas aí não precisa de mim nem de qualquer outra ajuda. ${ }^{392}$

Se não há como fugir ao peso da lei e a condenação é certa, a liberdade é apenas retórica, o que valeria tanto no processo de Josef $\mathrm{K}$. como nos processos ditos cotidianos, no próprio desenrolar de sua existência individual em inter-relação com o mundo: "a diferença é que a absolvição aparente exige um esforço concentrado e temporário, e o processo arrastado um esforço muito menor, mas duradouro ${ }^{393 " . ~ O ~}$

A classe social como origem do pensamento que aliena e ideologiza, afastando o indivíduo do seu semelhante. O sujeito também é sujeitado pela estrutura.

${ }^{392}$ P., p. 164

${ }^{393}$ P., p.168. Deleuze vê esta frase de Kafka como o indicativo de passagem de modelos sociais entre as sociedades disciplinares e as de controle: "Nas sociedades de disciplina não se parava de recomeçar (da escola à caserna, da caserna à fábrica), enquanto nas sociedades de controle nunca se termina nada, a empresa, a formação, o serviço sendo os estados metaestáveis e coexistentes de uma mesma modulação, como que de um deformador universal. Kafka, que já se instalava no cruzamento dos dois tipos de sociedade, descreveu em $O$ processo as formas jurídicas mais temíveis: a quitação aparente das sociedades disciplinares (entre dois confinamentos), a moratória ilimitada das sociedades de controle (em variação contínua) são dois modos de vida jurídicos muito diferentes, e se nosso direito, ele mesmo em crise, hesita entre ambos, é porque saímos de um para entrar no outro." (Conv., p.252). O fato do processo ser prorrogado indefinidamente poderia significar, na visão de alguns, a conservação da liberdade por mais tempo antes da execução da sentença, mas isso pode ser visto também como um novo tipo de prisão, sem grades: a sociedade moderna. "A prisão como segmentaridade rígida (celular) remete a uma função flexível e móvel, a uma circulação controlada, a toda uma rede que atravessa também os meios livres e pode aprender a sobreviver sem a prisão. Parece um pouco com a "prorrogação indefinida" de Kafka, que já não necessita de detenção nem de condenação" 
discurso da liberdade esconde em si um subtexto de disciplina e normatização em trechos como a apresentação de Josef $K$. ao juiz de instrução (em que o protagonista padece da ilusão de controle sobre o rumo do processo) ou todo o encontro do protagonista com o sacerdote, quando a entrada pela porta, ou a libertação do tormento da espera, guarda em si a aceitação de todo o texto da Lei, assim como da hierarquia relacionada a este. "A liberdade é o sonho de angústia de Kafka"394. O estranho aqui reside no fato de que ao tentar entrar na Lei, o homem do campo se mostra já dentro dela, mas pelo lado de fora, seguindo escrupulosamente as determinações do representante desta "legalidade" 395 . Seguindo a Lei sem estar nela: quando a porta se fecha, o homem do campo já está para dentro, e o que se cerrou foi a saída.

Como nascemos imersos dentro de um sistema de relações sociais, a possibilidade de saída se tornaria inexistente. A negação do sistema (seja pela ausência do trabalho ou até da vida) apenas o reafirmaria, e a anulação máxima do indivíduo (o alienar-se de si, substituído ou por uma

(Conv., p. 161). O novo modelo apontado por Kafka chega para substituir a lei, símbolo e ferramenta das sociedades disciplinares, mas esta nova máquina transcendente, esta nova organização normativa descontínua e horizontal, ainda não está desenhada, logo não temos a noção clara de sua operação. O processo contra Josef $\mathrm{K}$. abriga esta dupla situação de ser regulado por um dispositivo legal hermético e definido (com início, meio e fim) e simultaneamente não ter início (ninguém sabe quem caluniou Josef $\mathrm{K}$. e do que ele foi acusado) nem fim. Conforme CHEVITARESE e PEDRO (2003) "Compreender O Processo como um romance interminável significa renunciar ao "final" proposto no Cap. X.: a execução de K. Deleuze destaca que "nada nos diz que o capítulo final tenha sido escrito ao fim do Processo; pode ser que ele tenha sido escrito no início da redação (...) Poderia ser um sonho situável no correr do romance (...) Essa maneira de terminá-lo pela execução de K. é contradita por toda démarche do romance, e pelo estado de 'prorrogação ilimitada' que regula o Processo." (DELEUZE, 1977, p. 66 - grifos nossos)

${ }^{394}$ ANDERS, 2007, p. 37

${ }^{395}$ A ausência de liberdade se dá exatamente onde mais ela parece existir: o homem do campo ainda não está oficialmente dentro da lei, ou seja, seria livre. Mas já segue os ditames desta, ainda que do lado de fora da porta. Tanto para Adorno como para Deleuze, tal assincronia entre a liberdade e sua negação são características dos tempos em que a decisão das pessoas em seguir o sistema não se dá pela ordem, mas pelo convencimento efetuado pelos meios de comunicação e da expansão desenfreada da tecnologia, seja com as nomenclaturas de Sociedade Administrada (Adorno) ou Sociedade de Controle (Deleuze). Quanto maior a liberdade aparente, menor é a de fato, pois as opções para o exercício de tal liberdade - seja do consumo, da informação, do entretenimento - já estão determinadas previamente, produzindo subjetividades pré-fabricadas e controladas, às quais o próprio indivíduo busca desesperadamente se adequar para se sentir único e simultaneamente como pertencente ao grupo. 
coletividade forçada ou por uma individualização artificial) é condição de princípio da organização hierárquica da sociedade. A cena de Na Colônia Penal, na qual o oficial programa a máquina de tortura para executá-lo impiedosamente, é didática neste sentido: a eficiência completa da máquina é também a negação da vida; a perfeição do ato é a completa destruição do agente; a realização plena do desejo de conservação do sistema combinada com eficiência técnica a toda prova. O oficial encontra seu fim (ou objetivo) em sua mais completa alienação: o alienar-se de si mesmo em prol das máquinas sociais, machina machinarum reguladora da relação ato-vontade ${ }^{396}$. E assim como o oficial, vivemos da mesma forma, longe de nós mesmos e dentro da máquina ${ }^{397}$ : Kafka coloca-nos em situação de desconforto, pois tal abandono que está oculto no cotidiano se desvela em especial crueza em sua obra.

Não é este o mundo que o escritor checo deseja para si ou para qualquer pessoa: em suas próprias palavras,

Você pode se conter diante dos sofrimentos do mundo - é algo que tem liberdade de fazer e corresponde à sua natureza, mas talvez seja esse autocontrole o único sofrimento que você poderia evitar ${ }^{398}$.

396 Para Deleuze, "o que sofre ou goza em Kafka não é um pai, um super-eu ou um significante qualquer: é já a máquina tecnocrática americana, ou a burocrática russa, ou a máquina fascista" (K., p. 21). Uma situação na qual o conceito de individualidade já está perpassado pelas "potências diabólicas" de um mundo que é como o pai da Carta: técnico, funcional, rápido (o que reforça a visão benjaminiana da relação entre figuras da burocracia e figuras paternas em Kafka). Considerando que a literatura menor tem como uma de suas características tal caráter político, ou no mundo, indivíduo e sociedade existem em interpenetração, e tal caráter não dá espaço para diálogos dentro do triângulo pai-mãe-filho, já que esta relação familiar é tocada e esgarçada por outras, externas e sociais, que concorrem em sua composição: a história de um - seja ele Gregor ou Josef K., ou o rato que nos conta sobre Josefina - é a história de todos, a história que se guarda em si contra este mundo e a deste próprio mundo. Nas palavras do próprio Kafka, novamente, "a literatura tem menos a ver com a história literária do que com o povo" (Diários, 25 de dezembro de 1911).

397 A dimensão política da alienação e da perda de si já foi abordada no decorrer do trabalho, mas nunca é demais reforçar que a fragmentação da consciência de si possui relação direta com a incapacidade de um indivíduo ou de um povo de estabelecer cadeias de ação social de acordo com seus interesses e os da coletividade, tornando-se passível de manipulação por um sistema de processos dos quais muitas vezes o indivíduo nem desconfia. Este caráter de "ingenuidade" ou ignorância do indivíduo perante o sistema está presente em diversas obras de Kafka.

${ }^{398}$ Aforismo 103. EFK, p. 206 
Da análise desta passagem, surgiria um Kafka surpreendentemente interessado no que se passa em torno de si. A visão de um Kafka alheio ao mundo, tradicionalmente atribuída ao autor, não parece fazer sentido se aplicada a este aforismo, visto que evitar o sofrimento do autocontrole perante aquilo que $\mathrm{o}$ mundo traz de daninho equivale a sair da imobilidade em direção a algum tipo de ação. A perda do controle, no caso, é uma escolha de engajamento: algo que não é o imobilismo precisa ser feito, para que ao menos este sofrimento seja evitado. Não se fala de um confronto direto ou de um engajamento nos moldes revolucionários, mas sim de algo que poderia ser definido como a "astúcia ${ }^{399 "}$ de Kafka: a denúncia velada, a referência a algo que não está escrito. A alegoria literal como o que cria o espaço/estranhamento.

Ao adotarmos a definição de que a arte é algo que resiste ou desafia a sua própria representação, algo que é mais do que nos é mostrado imediatamente, a leitura da obra de Kafka permite - por sua astúcia - uma aproximação severa entre o caráter político evidente da literatura menor deleuziana (atravessada pelo meio social onde se desenvolve) e a assertiva adorniana de que não há mediação entre arte e sociedade (pois a mediação, conforme Adorno, "não se limita a perguntar como a arte se situa na sociedade, mas reconhece como a sociedade se objetiva nas obras de arte $\left.{ }^{400 "}\right)$. Esta "torção do dilema político da estética supõe uma outra torção na própria definição do processo da arte ${ }^{401 "}$, tomado agora uma forma de resistência a todo um sistema/mundo no qual ela surge.

Fala-se então de resistência não apenas no sentido de oposição ou combate como também de "afirmação de um modo de existência. Trata-se

${ }^{399}$ A observação de Adorno sobre a relação de Kafka com o poder e o mito funciona de forma precisa neste contexto ("Kafka não pregou a humildade, mas um comportamento mais testado contra o mito: a astúcia". AsK, p. 268). Política e cadeias de poder estão intrinsecamente ligadas.

${ }_{400}$ ADORNO, 1988, p.114

401 RANCIĖRE, Jacques. Será que a Arte resiste a alguma coisa? Artigo disponível em http://www.rizoma.net/interna.php?id=316\&secao=artefato. Publicado em 17/12/2008. Acessado em 17/03/2009 às 14:01h 
de uma re-existência, já que na atualidade, só a vida é capaz de resistir ${ }^{402 " . ~ D e s s a ~ m a n e i r a, ~ a s ~ f i g u r a s ~ c r i a d a s ~ p o r ~ K a f k a ~ g a n h a m ~ n o v a s ~}$ possibilidades de interpretação: novas existências, reinventadas por meio do estranhamento que causam ${ }^{403}$.

Podemos ver a morte do oficial no conto Na Colônia penal como a epítome deste descortinar de possibilidades de ação e como uma forma de colocar tal problema em discussão. Para Deleuze, com a execução "o homem introduz-se completamente ${ }^{404 " ~ n a ~ m a ́ q u i n a, ~ i m p r e g n a n d o-a ~ d e ~}$ humanidade. Na negação determinada de Adorno, trata-se de afirmar o humano em oposição completa à máquina. Mas a resistência, no caso, ocorre pela integração para destruir/recriar, pela oposição direta de forças ou surge de uma imbricação tensa de ambas as visões?

Cremos que no desenvolvimento deste trabalho tal tensão pôde ser mapeada, ainda que certamente de forma incompleta, tanto na análise da linguagem como da estrutura da obra de Kafka, tornando possível

402 ROQUE, 2003, pp.24-25 apud CHEVITARESE (2003). A resistência soa como uma contrainformação em relação à sociedade, como ato de negação ou de ressignificação. Um ponto de fuga descolado simultaneamente do protagonista, da história e do leitor, como o narrador original de Kafka. Malraux, citado por Deleuze, dirá que "a arte é a única coisa que resiste à morte" (O Ato de Criação, conferência publicada na Folha de S. Paulo de 27/06/1999), Ou seja, permanece para além desta. É resistência no espaço e no tempo, assim como uma prática de resistir. A re-existência, em um quadro como o que se vivencia atualmente (cfe. VIRTANEN) exigiria a ressignificação do chamado "pathos da distância, a subjetividade humana sem nenhuma direção ou tarefa específica, apática, indiferente e que possui uma imunidade paradoxal para qualquer tentativa significativa de organização" ( $p$. 66). Esta reorganização somente seria possível se, partindo desta apatia, buscássemos invertê-la: da ambivalência ou instabilidade resultante do "isolamento do ser humano de si mesmo" e do convívio com o outro poderiam advir novas relações de cooperação. A obra kafkiana, ao mostrar a fratura do Eu, apontaria a necessidade de superá-la, tendo como ponto de partida esta mesma fratura. Assim, o sujeito ainda existente no interior da subjetividade definida pelo mercado e o processo de resgate deste sujeito de dentro desta "subjetividade constituída" passa a ter um caráter político. Isso torna esta linha de pensamento muito similar à apresentada por Adorno, já abordada anteriormente.

${ }^{403}$ Continuando a relação entre existência, resistência e morte, que poderiam caracterizar o processo da arte como um todo (e não somente em Kafka), Deleuze observa que "basta contemplar uma estatueta de 3.000 anos antes de Cristo para descobrir que a resposta de Malraux é uma boa resposta. Poderíamos dizer então, de forma mais tosca, do ponto de vista que nos interessa, que a arte é aquilo que resiste, mesmo que não seja a única coisa que resiste. Daí a relação tão estreita entre o ato de resistência e a obra de arte. Todo ato de resistência não é uma obra de arte, embora de uma certa maneira ela faça parte dele. Toda obra de arte não é um ato de resistência, e no entanto, de uma certa maneira, ela acaba sendo" (idem)

${ }^{404}$ K., p 26 
reconhecer em sua produção os sintomas de um processo político-social que atinge seu ápice no presente: a coisificação do homem e as mudanças sociais que originam tal processo e simultaneamente decorrem dele. Conforme já visto, Adorno localiza Kafka como alguém que evidencia o funcionamento da sociedade burocrática administrada. Já Deleuze caracteriza o escritor checo como aquele que, com sua obra, representa a passagem entre os dois modelos sociais apresentados em sua produção filosófica: as sociedades disciplinar e de controle.

Apesar das diferenças de terminologia ou de aparatos de conceituação, temos uma coincidência de objeto/processo histórico ${ }^{405}$. Se Adorno declara que Kafka traz o conceito da desumanização e da estranheza ao eu para a berlinda, Deleuze vê esse homem perdido no mundo no cruzamento dos modelos que indica. Mantendo-se em terreno deleuzoguattariano, desnudar os escritos kafkianos equivaleria a especificar o funcionamento dos dispositivos que estruturam estes desenhos de sociedade:

Só acreditamos numa política de Kafka, que não é nem imaginária nem simbólica. Só acreditamos numa ou em máquinas de Kafka, que não são nem estruturas nem fantasma. Só acreditamos numa experimentação de Kafka,

\footnotetext{
${ }^{405}$ CHAUÍ (2012, informação verbal), a partir da leitura de Merleau-Ponty e Claude Lefort, observa que o momento histórico é imanente à obra do pensamento (categoria na qual podemos incluir tanto a filosofia como a arte/literatura), pois toda produção (a escrita, por exemplo) é uma apreensão (leitura) do e no momento em que a obra é produzida. Quem escreve lê o que escreve ao mesmo tempo. Assim, a obra de um autor trataria simultaneamente do momento espaço-temporal em que é escrita e do que ela aponta para o devir (agora presentificado) ou, ainda, aquilo que permanece e tem caráter, digamos, "universal". A própria interpretação da obra por aqueles que a recebem compõe o corpus da obra. A obra de Kafka teria em si, de forma intrínseca e imbricada, o momento histórico no qual foi produzida, as questões pessoais e político/sociais, o indicativo dos processos que ocorrem a partir desta escrita em direção ao futuro e até mesmo as mais diversas interpretações possíveis para seus textos - também elementos constituintes da obra em si. Uma obra do pensamento que perdura é a que fala simultaneamente ao presente e ao que virá, pois sempre levantará questões maiores do que sua circunscrição imediata. A expressão adorniana de que a autoridade de Kafka emana dos textos (no que Deleuze concorda) não significaria, então, reduzir sua leitura a uma exegese ou a um formalismo metodológico, mas exatamente conhecer seus elementos constituintes, suas interpretações (mesmo para descartá-las) e suas "linhas de fuga" (utilizando um termo deleuziano propositadamente) imanentes à obra do autor checo.
} 
sem interpretação nem significação, mas somente protocolos de experiência ${ }^{406}$

A relação entre arte e política se torna explícita: aquela, trespassada pelas linhas de força do mundo que a abriga, é uma experiência que se dá no dito real, e seus efeitos são sentidos neste tecido. Neste ponto, os conceitos de Deleuze e Adorno se completam rumo a uma definição de arte menor, compartilhando as mesmas características. A "arte política" decorre, então, de sua inserção no mundo da vida como forma de resistência.

Viver é em si um ato político - o estar em relação com o que o cerca - e o estar no mundo é algo sempre presente em Kafka, mesmo que em uma sala ao lado, mesmo que de forma marginal. O artista contempla de fora e ao mesmo tempo está imerso no mundo, como Gregor Samsa eternamente preso no quarto enquanto tudo se passa nos ambientes contíguos, mas nem por isso deixando de atuar. Resiste-se às potências diabólicas ${ }^{407}$ do mundo no próprio mundo.

O papel do desejo e da pulsão também ganha uma nova dimensão, pois antes era fruto da interdição realizada pela lei (era submetido e impunha sua própria submissão): "não é Édipo que produz a neurose, é a neurose (...) que produz Édipo ${ }^{408}$, o valor de mercado da neurose". Deve-

\footnotetext{
${ }^{406} \mathrm{~K}$, p. 17
}

407 Construindo um paralelo entre Deleuze e Lyotard, se estas potências diabólicas (fascismo, stalinismo, tecnocracia) representam o inumano da sociedade, Kafka responde a isto revelando as possibilidades contra este inumano por meio de suas figuras subhumanas: o tornar-se animal, o devir-animal como macaco, inseto, cachorro - não como arquétipo ou substituto do pai, mas como intensidades liberadas "onde os conteúdos se libertam das suas formas assim como de sua expressão, do significante que o formaliza" (K, p. 13)

408 K., p. 21. Deleuze e Guattari combatem com especial fúria o que chamam de psicanalização excessiva de Kafka, principalmente nas leituras da "Carta ao Pai", vista como epítome de um complexo de Édipo latente (ou manifesto) na obra. Porém, segundo o próprio autor - e de acordo com seu biógrafo - não há este traço nos textos, e não se trata de sublimar pulsões, o que mostra um embate intrigante entre a ideia da literatura como expressão da intimidade de um autor (ou como representação de um Eu ou de um recorte específico no tempo e espaço) e a produção de linhas de fuga em relação aos cenários descritos: "Kafka sabe perfeitamente que nada disso é verdade: a sua inaptidão para o casamento, a sua escrita, a sedução do seu mundo desértico intenso têm motivações 
se entender a neurose, então, para além do "desejo já submetido que busca comunicar sua própria submissão409", já que um desejo não é algo que tenha existência ontologicamente determinada, não é autônomo em si. A categoria de desejo pressupõe uma relação direta com uma subjetividade e uma coletividade (um socius): o desejo é um processo em um indivíduo ou coletividade, não uma forma ou um ente.

A neurose sim representa um ente externo, as "potências diabólicas' que se alegram sem medida por poder irromper em nós ${ }^{410 "}$. Como em um jogo de polaridades, temos pares conceituais operando no bloqueio e ao mesmo tempo no estímulo deste desejo: repressão e impulsão, auto-alienação e recalque, autojulgamento e condenação ${ }^{411}$. E a produção e experimentação surgem como forma de vencer a interdição da neurose ${ }^{412}$ : o desejo agora se torna excesso, produção que se afirma a si mesma - se torna política, práxis.

Kafka tematiza, por meio de sua prosa econômica e tensa, a política como sistema de regras e (des)organização de uma sociedade em mutação ${ }^{413}$. E também a política (o modo de ação e organização) do ser humano ao buscar uma maneira de lidar com esse processo ${ }^{414}$. A pena de

totalmente positivas do ponto de vista da libido, e não são reações derivadas de uma relação com o pai" (K., p. 15)

${ }^{409}$ K., p. 15

${ }^{410}$ K., p. 23

${ }^{411}$ Tal jogo de polaridades poderia ser estabelecido também entre resistência e mundo, mas de uma forma que nos leve a uma superação deste por aquela. Apesar da recusa clara de Deleuze à formação de qualquer sistema, principalmente polar ou dialético, esta recusa não é um impeditivo à ultrapassagem, se pensarmos que o rizoma - figura-base dos agenciamentos deleuzianos - pode ter elementos em oposição e que essa oposição seja o que impulsione ao devir, sem a obrigatoriedade de uma síntese dos opostos: uma inversão dialética da própria dialética que é criticada. Leituras múltiplas, como rizomas, são sempre bem vindas, e da multiplicidade brotam novos significados que são, em si, revolucionários.

412 VIRTANEN (2011) observa que, no quadro social atual, a neurose não se caracteriza mais por uma interdição de significados ou do desejo, mas por uma "psicose relacionada à sobrecarga de energia e informação" (p.59) e consequentemente pela perda de centros de sentido que operem como referenciais. Se o excesso pode romper a interdição, pode também criar novas cadeias de arbítrio.

${ }^{413}$ Cf. nota 392

414 BOSI (2008) observa que a relação entre narrativa/literatura e resistência se dá, de praxe, em dois níveis: quando a resistência é o tema da narrativa (como a literatura de resistência na França, com profundo compromisso ético e político - o engajamento sartreano) e quando ela é forma imanente da escrita, ou quando suas tensões internas nos levam à posição de desvelamento da relação sujeito/contexto existencial e histórico. Assim, 
Kafka volta-se então não contra ele mesmo, como em um tribunal íntimo, mas contra seu tempo ${ }^{415}$. Para Deleuze, "um escritor não é um homem escritor, senão um homem político416". Para Adorno, "não há sistema sem resíduo. Contemplando-o, Kafka profetiza o futuro ${ }^{417 " . ~ J a ́ ~ K a f k a ~ m o s t r a ~}$ um otimismo - ou esperança - insuspeitos na capacidade do ser humano de sair de seu "sonambulismo":

A maioria dos homens não é ruim - disse Franz Kafka enquanto falávamos do livro de Leonhard Frank, O homem é bom. - Os homens tornam-se maus e culpados porque falam e agem sem imaginar o efeito que terão suas palavras e

conforme o autor, a resistência seria "um movimento interno ao foco narrativo" (p. 134). Em Kafka, a segunda acepção do termo é facilmente percebida, mas para Bosi a primeira também é presente. A "coexistência de absurdo e construção de sentido, de desespero individual e esperança coletiva; (...) de escolha social arrancada do mais fundo sentimento de impotência individual" (p.128) que caracterizaria o pensamento existencialista engajado politicamente à esquerda (do qual Sartre, Camus, Bernanos, etc., seriam exemplos claros) já se encontra na obra kafkiana, conforme o próprio Camus expõe no Mito de Sísifo. Este posicionamento pressupõe um profundo senso ético e uma atitude de confronto que não se dá pela simples oposição, mas por uma nulificação da realidade (relações existentes) por meio da criação de uma linguagem/palavra "radicalmente antiburguesa, não conformista, revolucionária, voltada para a construção do novo Homem em uma perspectiva imanente" (p.129). A segunda acepção de resistência - que surge da tensão causada pela própria linguagem - "não resgata apenas o que foi dito uma só vez no passado. (...) Também o que é calado no curso da conversação banal, por medo, angústia ou pudor soará no monólogo narrativo, no diálogo dramático. E aqui são os valores mais autênticos e mais sofridos que abrem caminho e conseguem aflorar à superfície do texto ficcional" (pp. 134-135). Desta forma, a linguagem opera como maneira pela qual o sujeito pode, em vez de permanecer imerso nos processos mecânicos do cotidiano, experienciar um deslocamento que o permita ver a si mesmo dentro do corpus social: "a escrita pode cavar um vazio nessa espessa materialidade. O vazio, negatividade grávida de um novo estado do ser, é a consciência jamais preenchida pelo discurso especular das convenções ditas realistas" ( $p .134)$. A leitura da Carta ao Pai como um libelo antiautoritário e de imensa dimensão política ganha corpo com tal visão, assim como as transformações animais/humanas exemplificam tal deslocamento.

415 "Kafka propõe-se a extrair das representações sociais os agenciamentos de enunciação e os agenciamentos maquínicos e de desmontar esses agenciamentos" (K., p. 46). Mas isso não é feito apenas como denúncia, mas também como uma desterritorialização: expandir o processo ao limite do esgarçamento.

${ }^{416}$ K., p. 17

417 AsK, p. 253. Interessante observar a coincidência plena entre as visões de Adorno e Deleuze sobre esse caráter político/"profético" da obra kafkiana. O francês comenta que "de uma ponta à outra [Kafka] é um autor político, adivinho do mundo futuro" (K., p. 119)., reforçando a definição de política como a relação das forças sociais e da arte como forma de captura e entendimento das interações de tais forças. Uma arte política/social na sua forma mais direta. Logo, uma arte que não pode ser vista como uma interpretação ou representação, mas como um "protocolo social-político" (K, p. 73), como destacamos. 
seus atos. São sonâmbulos, não patifes. ${ }^{418}$

Ao mesmo tempo que sua arte é política por ocorrer em um mundo que a suporta, Kafka abre a expansão das possibilidades de ação neste mundo, talvez visando despertar o homem de seu sonambulismo. A Kafka se aplica a ideia de que "a literatura, por ser ficção, resiste à mentira. É nesse horizonte que o espaço da literatura, considerado em geral como o lugar da fantasia, pode ser o lugar da verdade mais exigente ${ }^{\prime 419}$ : o lugar onde o autor cumpre o compromisso consciente com tal despertar da consciência.

Por meio da literatura, Kafka coloca-se ${ }^{420}$ à margem de si, como um duplo de si mesmo, um inseto ou um animal falante, enquanto interage com o mundo - nos libertando das "cadeias da existência cotidiana421" - e abre a possibilidade de realizar tanto a denúncia como uma ressignificação de um novo mundo, efetuando uma "cartografia do outro de todo o mundo, o que faz do mundo um outro (...) tornando assim possíveis

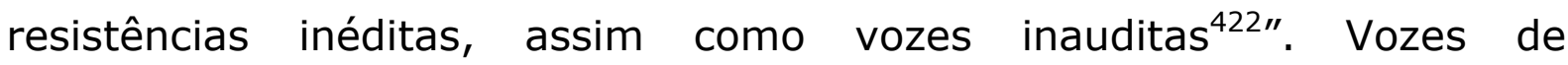
estranhamento, que nos dizem muito mais do que o que está escrito.

\footnotetext{
418 JANOUCH,1971, pp. 112-113

${ }^{419}$ BOSI, 2008, p.135

${ }^{420} \mathrm{E}$ também nos coloca à margem de nós mesmos no processo.

${ }^{421}$ PELBART, 2000, p.298

422 idem
} 


\section{ExcurSO: FORMA E ESTILO}

Alguns elementos da obra kafkiana foram objeto de uma análise mais atenta tanto por Adorno como por Deleuze. Em especial, há um elemento que, apesar da diferença de terminologia entre os autores citados, parece estar em destaque para ambos. Se, para estes dois pensadores, a dimensão política de uma obra estaria expressa em sua própria escrita, como isso aproximaria as definições de forma da obra, por Adorno, e estilo de uma obra, por Deleuze, não apenas nas análises sobre o escritor checo, mas em tudo aquilo que é chamado de trabalho do pensamento?

É necessário retomar estes conceitos para averiguar a possibilidade de sua articulação. Para Deleuze, o estilo de um texto - o como algo é dito - é parte integrante do próprio conceito a ser descrito no texto, ou seja, do que é dito. Na história do pensamento, um mesmo objeto (mental, social, etc.) é abordado de forma diferente por filosofias diferentes até mesmo pelo uso de um outro léxico, gramática ou idioma.

É interessante observar que aquilo que Hegel atribui à Arte Grega (ou seja, que esta só poderia ser da forma que era, naquele tempo e sob aquelas condições específicas) reaparece aplicado ao trabalho do pensamento de forma tortuosa mas instigante: uma filosofia não é definida apenas pelo tempo na qual foi elaborada, mas pelo próprio fato de ter sido elaborada daquela forma, ou melhor, pelo estilo em que foi elaborada. E o estilo de um filósofo é parte integrante de sua filosofia.

A definição de estilo, de acordo com a análise literária, consiste nos diversos tipos de linguagens usadas na elaboração de um discurso, de forma a que este discurso seja compreensível e identificável pelo leitor. Desta forma, é possível dizer que estilo é 
um estilo na forma de apresentar pensamentos ou sentimentos através da palavra ${ }^{423}$.

A função dos personagens conceituais, como figuras de estilo, é apresentar uma resposta à questão que motiva a sua criação, mas tal resposta está subsumida às condições que geraram sua problemática motriz (o que inclui até mesmo questões geográficas, tradições culturais, idiomas, etc. Um exemplo disso estaria na própria terminologia "Filosofia contemporânea de matriz francesa" ou "matriz alemã", por exemplo). Um mesmo problema pode ser objeto de conceituações diversas.

Nunca uma filosofia é idêntica a outra, portanto. Podem ocorrer semelhanças, mas não uma coincidência conceitual completa, mesmo com a coincidência de objetos que estão sob análise. Logo, é possível o estabelecimento de um sistema que envolva diversas filosofias, mas não é possível entender uma filosofia por meio de outra. Até mesmo os comentadores fazem parte do corpus de estudo da filosofia principal, da mesma forma em que a leitura de uma obra é um componente da máquina de expressão da própria obra.

Com base nisso, a visão deleuziana poderia ser comparada ao pensamento de Adorno de que as contradições da época em que uma obra é gerada retornam como contradições ou elementos da forma da obra, de sua apresentação. De acordo com Selligman, Adorno é afiliado a uma "certa tradição de pensamento alemã, que via na forma, na apresentação (Darstellung), um momento indissociável do trabalho do conceito e da reflexão ${ }^{424 " .}$ Assim

para Adorno não existiria a possibilidade de separar, sem mais, o conteúdo da forma de uma obra. Toda tentativa de redução representaria uma traição do original - e isso não

\footnotetext{
${ }^{423}$ FERREIRA, 2012, p.2

${ }^{424}$ SELIGMANN, 2009, p.6. A influência hegeliana em Adorno é visível nesta questão: para Hegel, em sua Estética, a obra de arte é a expressão (Darstellung) da verdade ideal em uma forma sensível, ou o resultado do trabalho humano em uma comunidade, o Espírito objetivo. Deixando o idealismo de Hegel de lado, assim como a necessidade de síntese da dialética hegeliana, percebe-se a proximidade entre os conceitos citados.
} 
significa de modo algum que ele reduzisse a obra a uma intencionalidade primária, pura, que seu autor teria passado sem mediação para o texto ${ }^{425}$.

Porém, isso que é chamado de apresentação não poderia ser lido como estilo? A recepção de uma obra (sua pragmática) está diretamente relacionada com a forma como o autor ou escritor manobra a linguagem e a codificação oferecida ao leitor. Tudo pode ser entendido como a forma que o autor usa para se fazer entender, ou de se fazer respeitar esteticamente.

Quando falamos de apresentação, automaticamente se fala de estilo, no sentido descrito acima: uma inter-relação entre forma/léxico e conteúdo, na qual ambos se impulsionam e se limitam mutuamente. Conforme Adorno, "faz parte da técnica de escrever ser capaz de renunciar até mesmo a pensamentos fecundos, se a construção o exigir"426.

Deleuze e Adorno destacam que a prosa, em Kafka, é mais do que um veículo da obra; ela é um elemento constitutivo que, em si, transmite um significado. Das características de estilo a serem analisadas em Kafka, não é de pouca importância a análise da estrutura de linguagem.

Como exemplo, a análise estatística ${ }^{427}$ da prosa kafkiana mostra-nos que, na medida em que a produção do autor aumentava, o vocabulário utilizado recrudescia, mostrando que o estilo do autor se solidificava. 0 léxico utilizado em Amerika é mais rico do que o encontrado em $O$ Processo e O Castelo.

No nível sintático, fatores como a pontuação, a preferência pelo subjuntivo e o emprego de certas preposições e conjunções são determinantes na produção do efeito desejado, assim como o uso de advérbios e expressões condicionais deixa espaços livres para a

\footnotetext{
425 idem, ibidem

${ }^{426}$ MM, p.73

${ }^{427}$ Cfe. CURCIO (2007), in http://www.textodigital.ufsc.br/num04/veronica.html
} 
interpretação daquilo que está descrito/escrito no nível semântico. Conforme Curcio,

Günter Anders destaca a frequência de subjuntivos e o forte uso da conjunção wenn (se), e esta última é justamente uma das particularidades que Martin Walser propõe sobre a limitação da prosa kafkiana; são os "ses" das possibilidades e impossibilidades que se manifestam também como as co-ocorrências de vielleicht e wahrscheinlich, e nas sutilezas do narrador com wie wenn, als $o b^{428}$.

E de que forma esta indeterminação pode nos dizer algo sobre o pensamento de Kafka, assim como da relação entre pensamento, obra e socius no qual o escritor estava inserido? Conforme já abordado, a indeterminação do narrador pode apontar uma fratura no conceito de Sujeito, o que reflete, de certa forma, o processo de perda da identidade concomitante às mudanças nos modelos econômico e político que se aceleravam desde meados do século XIX. A época da perda das certezas parece trazer a Kafka uma certa angústia em relação à própria escrita e ao entendimento de si, o que é visível nesta passagem do Diário

Não escrevi muito sobre mim nestes dias, (...) em parte também por medo de trair o conhecimento que tenho de mim. Este medo justifica-se, porque uma pessoa só devia permitir fixar na escrita a sua autopercepção quando o puder fazer com a maior integridade, com todas as consequências secundárias e também com toda a verdade ${ }^{429}$.

As contradições de um tempo no qual as certezas do projeto iluminista eram rapidamente substituídas pelo florescimento de ideologias totalitárias e da alienação de si reverberam, inclusive, na ausência ou na negação da escrita. Segundo Pawel, a literatura, à época de Kafka, era

\footnotetext{
${ }^{428}$ CURCIO (2007), in http://www.textodigital.ufsc.br/num04/veronica.html. Vielleich significa "talvez" ou "possivelmente"; wahrscheinlich, "provável" ou "provavelmente"; wie wenn é "como se" ou "que se"; als ob significa "como se".

${ }^{429}$ D., p. 23
} 
vista como "uma espécie de religião430", um sintoma de uma era de desencantamento com a fé, os ritos e as tradições: "la mystique de qui ne croit à rien" (a mística de quem não crê em nada) ${ }^{431}$. A literatura, nesta visão, passa a ser uma tentativa de, por meio de palavras, dar significado ao existente.

Toda essa literatura é um esforço para romper a fronteira. Não fosse pela intervenção do sionismo, ela se teria facilmente transformado num novo misticismo, numa Cabala. Há tendências incipientes nesse sentido. O que se faz necessário, entretanto, é algo inconcebível, que lance raízes nos séculos ancestrais ou que as recrie por completo, e que, ainda assim, não se desgaste na tarefa, mas apenas dê início ao seu trabalho ${ }^{432}$.

Assim, a linguagem em si não pode ser mais entendida como um meio neutro capaz de representar os objetos físicos ou mentais de forma plena e integral ${ }^{433}$. A relação entre o que é dito e o como é dito, ou seja, entre significado e signo, esconde mais do que a simples intencionalidade do autor do discurso: esta relação reproduz, sugere ou critica o próprio meio social onde é gerada e registrada ${ }^{434}$.

430 PAWEL, 1986, p. 95. "Religião", aqui, pode ser entendida como um processo de construção de uma comunidade, que reforça (religa) seus laços por meio de atos, símbolos e discursos. A literatura ocuparia o lugar da história e da tradição como narrativa voltada a possibilitar a compreensão da realidade em que é engendrada e o estabelecimento de relações entre os componentes da comunidade. Por outro lado, esta narrativa seria capaz de influir na percepção desta realidade, funcionando de maneira análoga a uma ideologia.

${ }^{431}$ FLAUBERT, G., apud PAWEL,1986, p. 96.

432 KAFKA, apud PAWEL, 1986, p.98

433 A visão positivista é reproduzida pelo tratamento dado à linguagem pela Indústria Cultural: um instrumento de apresentação e exaltação da imediaticidade do presente. Do que se apresenta sem nuances ou intencionalidade. Por isso, o discurso crítico ou questionador das relações de produção e reprodução da cultura é visto como ideologizante: é fácil ver ideologia no discurso que critica as ações cotidianas, e quase impossível reconhecer que suas próprias palavras e ações são carregados de ideologia. A linguagem seria uma mimesis da realidade (ou de uma realidade), mesmo quando se refere ao fantasioso ou quando pretensamente teria isenção em relação ao real? Seria este o caráter político da própria linguagem? Esta seria a origem do caráter "menor" de uma literatura?

${ }^{434}$ A semelhança apontada por CURCIO (2007) entre as construções semânticas adotadas em diversos textos de Kafka e a linguagem dos jornais praguenses à época de sua produção, além de nos revelar um hábito de leitura do escritor, mostraria uma estratégia da escrita de Kafka: a semântica jornalística, por definição, estaria atrelada a uma descrição o 
Nunca há apenas uma voz em um discurso, mas várias. O unívoco não se verifica na prática: a polifonia é a característica básica de qualquer discurso. Assim a linguagem (forma da obra) ecoa, em suas entrelinhas, as contradições da época na qual é materializada. Pelo mesmo motivo, de acordo com Deleuze, Kafka seria a voz de todos os judeus de Praga do seu tempo, ou um sujeito coletivo de enunciação. Ou talvez como um estilo de ser e se expressar de um povo ${ }^{435}$.

A proximidade conceitual entre os dois filósofos sob análise não se restringe à questão de forma e estilo: conforme Seligmann, "para Adorno, filosofia é acima de tudo 'comentário e crítica'436", que só podem existir "no espaço da tradição e de sua crítica calcada politicamente no presente ${ }^{437 " .}$ Assim,

nas obras de arte - musicais, literárias e plásticas - Adorno aplicaria do modo mais original essas premissas. Para ele, a cultura não podia ser pensada separadamente da crítica; a esta cabe o papel de revelar a não-verdade da primeira. Assim, na Teoria Estética (sua última obra), Adorno apresentaria a estética como "a filosofia em si", e não como um campo dela, ou como a aplicação de teoremas ao universo artístico-cultural ${ }^{438}$.

A relação entre estética e pensamento também pode ser encontrada na produção deleuziana: o "criar conceitos" é a atribuição máxima da filosofia, mas que também é realizada pela arte e pela ciência, muitas vezes para problematizar situações que ainda não estão nominadas ou

mais objetiva possível da realidade ou do fato ocorrido. Ao mobilizar tal léxico jornalístico em suas narrativas "desloucadas", Kafka atribui, por meio da linguagem, status de verossímil ao que é inverossímil. A partir desta análise de CURCIO, pode-se teorizar que este procedimento de Kafka, em vez de tornar seu texto críptico, o faria surpreendentemente acessível às massas.

${ }^{435}$ Para PAWEL (1986), a literatura, por ser a ferramenta de Kafka para lidar com o malestar gerado pela sensação de não-pertencimento, do não-ser, tornou-se "uma insígnia daquela 'alteridade', daquele sentimento de ser diferente, que, para muitos dos que pertenceram à geração de Kafka, passou a ser a soma e a essência do judaísmo" (p. 57).

${ }^{436}$ SELIGMANN, 2009, p. 10

${ }^{437}$ ibidem

438 idem, p.11 
"conceituadas". O conceito, como obra de criação, é de todo modo uma criação estética e estilística do filósofo para dar conta de um problema específico.

O filósofo é o amigo do conceito, ele está em potência de
conceito. Isto quer dizer que a filosofia não é uma simples
arte de formar, de inventar ou de fabricar conceitos, porque
os conceitos não são necessariamente formas, achados ou
produtos. Mais rigorosamente, a filosofia é a disciplina que
consiste em criar conceitos. (...) Criar conceitos sempre
novos, esse é o objeto da filosofia. ${ }^{439}$

Mesmo com a ressalva adorniana de que os objetos do pensamento são dados nos conceitos, mas não por meio destes simplesmente - isto é, que cada conceito contém em si uma constelação de elementos nãoconceituais que são componentes do processo de aproximação entre o conceito e o conceituado - a importância da estruturação de conceitos novos, vinculados à realidade que os gera, é terreno comum aos dois autores ${ }^{440}$. Criação, comentário e crítica de conceitos, calcadas no presente e indicativas do futuro.

Os conceitos criados estão sempre no passado em relação à suas críticas, também geradoras de novos conceitos que serão devidamente criticados. A cultura não pode ser pensada separadamente de sua crítica e vice-versa, uma dialética encontrada em todo o trabalho do pensamento (filosofia, arte e ciência). Para Adorno, na relação entre o conceitual e o não-conceitual é que é possível vislumbrar realmente o objeto ao qual o conceito se refere, e não nos extremos:

\footnotetext{
${ }^{439}$ OQF, p.9

440 É possível aproximar as "constelações" conceituais de Adorno do "campo de imanência" dos conceitos em Deleuze, mas esta relação não será abordada neste trabalho. Por enquanto, pode-se apontar que, se o campo de imanência é pré-conceitual (como afirma Deleuze), o espaço ocupado pelo conceito está em relação direta com esta préconceitualidade, ou seja, com o problema que originou a criação deste conceito. Pode-se afirmar, ainda, que de modo análogo, em Adorno (cfe. SELIGMANN, 2009) "a construção e a leitura das constelações e dos campos de força devem tensionar as diversas estrelas (a saber, os conceitos e suas configurações), a partir da força de gravidade que emana do presente" (p.13), o que significa dizer que há aqui também um dado apriorístico no processo, ou seja, "pré-conceitual": um fator que está na origem da elaboração do conceito.
} 
o conhecimento se dá numa rede onde se entrelaçam prejuízos, intuições, inervações, autocorreções, antecipações e exageros, em poucas palavras, na experiência, que é densa, fundada, mas de modo algum transparente em todos os seus pontos. Desta, a regra cartesiana segundo a qual só devemos nos ocupar com aqueles objetos "dos quais nosso espírito parece poder atingir um conhecimento certo e indubitável", fornece um conceito tão falso (...) quanto a doutrina que lhe é contrária, mas intimamente aparentada, da 'intuição das essências'441

O conceito pode ser visto como forma e figura de estilo do pensamento simultaneamente. Como ato criativo, se aparenta à arte ou toma elementos desta, mesmo que tais elementos não estejam vinculados à forma da obra de arte em sentido estrito, colocando a imaginação a serviço da razão. Tal identidade pode ser encontrada na constatação de que o escrever filosófico tem necessariamente um quê literário. Melhor dizendo, a escrita filosófica compartilha características com o processo de composição literária. O grande escritor e o grande filósofo são criadores e codificadores de realidades e conceitos, a partir do terreno da sua individualidade e do socius que o rodeia, por meio de um processo no qual a liberdade de criação se articula com o rigor do pensamento.

Sendo assim, por que razão a obra de Kafka é instigante a ambos os filósofos abordados como epítome desta relação entre arte e filosofia? A título de comparação, Kafka vê sua própria obra como a tentativa de "comunicar algo incomunicável, explicar algo inexplicável, falar de algo que sinto apenas em meus ossos e que só pode ser experimentado nestes ossos... ${ }^{442 " . ~ J a ́ ~ A d o r n o ~ v e ̂ ~ a ~ f i l o s o f i a ~ c o m o ~ " o ~ e s f o r c ̧ o ~ p e r m a n e n t e ~ e ~}$ mesmo desesperado de dizer o que não se pode propriamente dizer ${ }^{443 " . ~ E ~}$ a criação conceitual deleuziana - a filosofia como a "arte de formar, de

\footnotetext{
${ }^{441}$ TF, p. $69-70$

${ }^{442}$ Carta a Milena, in PAWEL, 1986, pp.95-96

${ }^{443} \mathrm{TF}, \mathrm{p} .63$
} 
inventar, de fabricar conceitos $444 "$ - é, ao fim e ao cabo, a busca por uma maneira de enunciar o que ainda não foi dito, um devir-linguagem para um devir-povo, o que só é possível realizar ao se encontrar o estilo (ou a forma) apropriados. Invertendo propositadamente os termos, a escrita kafkiana é seu estilo ao denunciar as contradições não-resolvidas da realidade, assim como sua forma de criar, inventar e fabricar/maquinar a resistência a estas contradições, de propor um novo caminho, menor ou revolucionário.

${ }^{444}$ OQF, p. 8 


\section{REFERÊNCIAS}

ADORNO, T. \& BENJAMIN, W. Correspondência 1928-1940. São Paulo : Ed. Unesp, 2012

ADORNO, T. \& HORKHEIMER, M. Dialética do Esclarecimento: fragmentos filosóficos. Rio de Janeiro : Jorge Zahar Editor, 1985

ADORNO, T. "Apuntes sobre Kafka", in , Prismas - la crítica de la cultura y la sociedad. Trad. Manuel Sacristán. Barcelona : Edicciones Ariel, 1962 , Anotações sobre Kafka, in sociedade. São Paulo : Editora Ática, 1998 Prismas, Crítica cultural e Dialética Negativa. Rio de Janeiro : Jorge Zahar Editor, 2009 Negative Dialektik. Frankfurt : Suhrkamp, 1975

Teoria Estética. Lisboa : Edições 70, 1988

Résumé sobre Indústria Cultural. Disp. Em http://www.robertexto.com/archivo5/resume adorno.htm. 2004 Indústria Cultural e sociedade. $2^{a}$ ed. São Paulo : Paz e Terra, , "Sobre a ingenuidade épica" e "Posição do narrador no romance contemporâneo", in Notas de Literatura I. São Paulo : Ed. 34, 2003

A arte é alegre? In: RAMOS-DE-OLIVEIRA, N.; ZUIN, A. Á. S.; PUCCI, B. (Orgs.). Teoria crítica, estética, educação. Campinas: Unimep, 2001. p. 11-18.

Minima Moralia: Reflexões a Partir da Vida Danificada. $2^{a}$ ed. Trad. L.E. Bicca. São Paulo: Ática, 1993

, Terminologia filosófica - Tomo I. Trad. Ricardo Sanchez Ortiz de Urbina. Madrid: Taurus, 1976

AGAMBEN, G. Profanações. São Paulo : Boitempo Editorial, 2007

ANDERS, G. Kafka: Pró e Contra. Tradução, posfácio e notas Modesto Carone. São Paulo: Cosac e Naify, 2007.

ANSCROMBE, J-C; DUCROT, O; TODOROV, T. Dicionário Enciclopédico das Ciências da Linguagem. $3^{a}$ edição, $4^{a}$ reimpressão. São Paulo : Ed. Perspectiva, 2010

ARAGON, L.E. O Anti-Édipo não é anti-psicanálise. Conferência. XXV Semana da psicologia Unimep - Cem anos da teoria da sexualidade e suas ramificações. $\quad$ Piracicaba, $2007 . \quad$ Disp. em www.pucsp.br/nucleodesubjetividade/Textos/antiedipoaragon.pdf

ARNAO, M. A distinção entre representação de palavra e representação de coisa na obra freudiana: mudanças teóricas e 
desdobramentos filosóficos. Ágora (Rio J.) [online]. 2008, vol.11, n.2, pp. 187-201. ISSN 1516-1498.

AUERBACH, E. Ensaios de Literatura Ocidental - Filologia e Crítica. Org. Davi Arrigucci Jr. e Samuel Titan Jr. São Paulo : Ed. 34/Duas Cidades, 2012

AVELAR, S.M.M. Benjamin e a Aura. Revista Exagium, vol I, Abril/2008. Disp. Em www.revistaexagium.com.br/edicoes/edicao\%201/savelar.pdf

BACKES, M. Prefácio, em KAFKA, F. Carta ao Pai. Porto Alegre : L\&PM, 2004

BARRENTO, J. O arco da palavra: ensaios. São Paulo : Escrituras Editora, 2006

BARROS, M.A.; BORDIN, L. Estética e política contemporânea: Bertolt Brecht e Walter Benjamin: uma prática estética contra a barbárie e em defesa da vida. Revista Ágora Filosófica (Universidade Católica de Pernambuco), ano 6, no 2, jul/dez 2006, pp. 67-102

BARTHES, R. Grau zero da escrita (seguido de novos ensaios críticos). São Paulo : Martins Fontes, 2000

BASTOS, T. O processo como alegoria de ser Judeu: Franz Kafka e um de seus destinos. Revista Psicol. clin., Rio de Janeiro, v. 19, n. 2, Dec. 2007 . Available from <http://www.scielo.br/scielo.php?script=sci_arttext\&pid=S0103$56652007000200011 \& \mathrm{lng}=$ en\&nrm $=$ iso $>$. $\quad$ access on 19 Mar. 2013.2 http://dx.doi.org/10.1590/S010356652007000200011 .

BEHRENS, R. "A Dialética negativa da negação determinada: algumas implicações estéticas na teoria crítica da sociedade de Theodor Adorno". Trad. Eduardo Soares Neves Silva. In DUARTE, R. et al (orgs) Theoria Aesthetica. Porto Alegre : Escritos, 2005

BENJAMIN, W. "Franz Kafka: a propósito do décimo aniversário de sua morte" e "O Narrador: considerações sobre a obra de Nikolai Leskov" in , Magia e Técnica, Arte e Política. São Paulo: Brasiliense, 1985 Arquivos. Notícia disponível no portal Terra. Link: http://diversao.terra.com.br/arteecultura/noticias/0, OI5432400EI3615,00-

Arquivos+do+filosofo+Walter+Benjamin+sao+apresentados+em+Paris $+p$ ela+primeira+vez.htm

BENSMAÏA. R, The Kafka Effect (Foreword). In: DELEUZE, G.; GUATTARI, F. Kafka: toward a minor literature. Minneapolis : University of Minnesota Press, 1986 
BEZERRA. C.C., Ocidente: Terra do Poente - Considerações sobre filosofia e literatura. Rev.Let. São Paulo, v.50, n2, pp 327-336, jul/dez 2010.

BOSI, A. Literatura e Resistência. $1^{\text {a }}$ reimpressão. São Paulo : Companhia das Letras, 2008

BROD, M. Franz Kafka: A Biography. New York: Da Capo Press, 1995. Disp.

http://books.google.pt/books?id=BOkXnR4TACMC\&printsec=frontcover\&hl $=p t-B R \&$ source $=g b s \_v p t \_b u y \# v=$ onepage $\& q \& f=$ false

BRUMER, A. O Humor Judaico em Questão. In: WebMosaica - Revista do Instituto Cultural Judaico Marc Chagall. V1 No2 - Jul-dez 2009

CAMUS, A. O Mito de Sísifo: ensaio sobre o Absurdo. Rio de Janeiro : Record, 2004

CANEVACCI, M. (org.) Dialética do Indivíduo: o indivíduo na natureza, história e cultura. Trad: Carlos Nelson Coutinho. São Paulo : Brasiliense, 1981

CAUSO, R. Ficção Científica, fantasia e horror no Brasil - 1875 a 1959. Belo Horizonte : UFMG, 2003

CARDOSO, M.J.d'E. Peirce, Lacan e a questão do signo indicial. Ágora (Rio J.) [online]. 2012, vol.15, n.1. Disp. em http://www.scielo.br/scielo.php?pid=S1516$14982012000100011 \&$ script=sci_arttext

CARONE, M. Lições de Kafka. São Paulo : Companhia das Letras, 2009 CEBRAP. No. $80 \quad$-Mar.2008. Disp. http://www.scielo.br/scielo.php?pid=S0101-

33002008000100013\&script $=$ sci_arttext O parasita da família, Revista Psicologia USP, no 3, p. 131$141,1992$.

CARSON, B. Towards a Postmodern Political Art: Deleuze, Guattari, and the Anti-Culture Book. Rhizomes: Cultural Studies in Emerging Knowledge 7 (2003). Ohio, EUA. Acesso em 28/11/2011 http://www.rhizomes.net/issue7/carson.htm

CHAUÍ, M. Fazer história da filosofia. Conferência plenária XV Encontro Nacional ANPOF. 26 de out. 2012. No prelo. 
CHEVITARESE, L.; PEDRO, R. A questão da 'liberdade' na Sociedade Tecnológica, por uma alegoria de Kafka e Dick. In: $27^{\circ}$ Encontro anual da ANPOCS, CD-ROM, 2003.

COHN, G. Introdução: Adorno e a teoria crítica da sociedade, em: Theodor W. Adorno (Coleção Grandes Cientistas Sociais 54). São Paulo : Ática, 1986.

COLERIDGE, S.T. Samuel Taylor Coleridge, ed. por H. J. Jackson. Oxford : Oxford University Press, 1985

COSTA, L.I.O., Destruição e transmissibilidade: o narrador Kafka na correspondência entre Benjamin e Scholem. Congresso Internacional Deslocamentos na Arte UFOP/UFMG/ABRE. Anais (pp. 129-138). Belo Horizonte, 2010.

COUTINHO, C.N., Lukács, Proust e Kafka. Rio de Janeiro: Civilização Brasileira, 2005

Entrevista. Editora Record. Disp. em http://www.record.com.br/autor_entrevista.asp?id_autor=2949\&id_entre vista $=100$.

CURCIO, V.R. Sintaxe da frustração: análise estatística do estilo de Kafka. Orientação: Prof.Dr. Alckimar Luis dos Santos. Dissertação de mestrado, UFSC, 2007.

Disp. http://repositorio.ufsc.br/xmlui/handle/123456789/89918

Repetições de Kafka: uma análise estatística. Texto Digital, Florianópolis, ano 3, n. 1, Julho 2007. ISSN 1807-9288. Disp. http://www.textodigital.ufsc.br/num04/veronica.html

DAVIS, G. Pode algo ser salvo ao ser defendido? Benjamin com Adorno. Revista Remate de Males, Campinas-SP, (30.1): pp. 25-44, Jan./Jun. 2010

DELEUZE, G. A filosofia crítica de Kant. Colecção O saber da Filosofia. Lisboa : Edições 70, 2000 Post-scriptum sobre as Sociedades de Controle. In:

Conversações: 1972-1990. São Paulo : Ed. 34, 1992. , Controle e Devir. In: Conversações: 1972-1990. São Paulo : Ed. 34, 1992

1985

Cinema 1: a imagem movimento. São Paulo : Brasiliense, Cinema 2: the time image. Minneapolis : University of Minnesota Press, 1989

, Critica y clínica. Barcelona : Editorial Anagrama, 1996 Rousseau: precursor de Kafka, Céline e Ponge. Arts, no 872, 6-12 junho, 1962. 
, Sacher-Masoch: o frio e o cruel. Trad. Jorge Bastos. Rev. técnica Roberto Machado. Rio de Janeiro : Jorge Zahar, 2009

, Lógica do Sentido. São Paulo : Perspectiva/EdUSP, 1974

1992

Conversações. Trad. Peter Pal Pelbart. São Paulo : Editora 34,

Foucault. São Paulo : Brasiliense, 1998

"O ato de criação". Trad. José Marcos Macedo. Em: Folha de São

Paulo, Caderno Mais!, 27 de junho de 1999

DELEUZE, G. \& GUATTARI, F. Kafka. Por una literatura menor. Trad. Jorge Aguilar Mora. México : Edicciones Era, 1978.

Kafka: toward a minor literature. Minneapolis : University of Minnesota Press, 1986

1977

Kafka. Por uma literatura menor. Rio de Janeiro : Imago,

Kafka. Pour une littérature mineure. Collection Critique. Paris

: Les Éditions de Minuit, 1975

Press, 1987

A Thousand Plateaus. Minneapolis: University of Minnesota Editora 34, 2010

Mil Platôs - Vols 1-5. São Paulo : Editora 34, 1995

O que é a filosofia?, Trad. Bento Prado Jr. e A.A. Muñoz, São

Paulo: Ed. 34, 1992

DUNKER, C.; SAFATLE, V.; SILVA JUNIOR. N. Fetichismo, reificação e Corporeidade: análise de uma patologia social. Disciplina do programa de pós-graduação em Filosofia. FFLCH/IP-USP. 2010

EAGLETON, T. Teoria da Literatura: uma introdução. $6^{a}$ edição. São Paulo: Martins Fontes, 2006

ECO, U. Seis Passeios pelos bosques da ficção. $2^{a}$ edição. São Paulo : Companhia das Letras, 1994

ELISSON, D. Ethics and Aesthetics in European Modernist Literature: From the Sublime to the Uncanny. Cambridge : Cambridge University Press, 2004

FAVARETTO, C. F. A cena contemporânea: criação e resistência. In: FONSECA, T.M.G.; PELBART, P.P; ENGELMAN, S. (Org.). A Vida em Cena: Teatro e subjetividade. Porto Alegre : EdUFRGS, 2008

Deslocamentos: entre a arte $e$ a vida. Congresso Internacional Deslocamentos na Arte UFOP/UFMG/ABRE. Anais (pp. 6576). Belo Horizonte, 2010

FEIL, G.S. Kafka Erótico. Revista Travessias, no 1. n/d. Disp. em www.unioeste.br/travessias 
FELDMAN, L. Humor judaico: o sorriso entre lágrimas. São Paulo : Webmosaica. 2009

FERRARI, S.C.M. Kafka, Benjamin: o natural e o sobrenatural. Revista Trans/Form/Ação, São Paulo, 30(2): 151-165, 2007

FERREIRA, J. O estilo literário. Ensaio disponível no endereço eletrônico http://www.usinadeletras.com.br/exibelotexto.php?cod=419\&cat=Ensaios \&vinda $=S$

FOERSTE, G.M.S. e CAMARGO, F.M.B. Estranhamento como categoria estética em arte. $19^{\circ}$ Encontro da Associação Nacional de Pesquisadores em Artes Plásticas "Entre Territórios" (Anais), pp 2057-2070. Bahia, 2010

FREITAS, N.A. Apontamentos sobre mímesis em Adorno e Benjamin. Comunicação disp. em www.ip.usp.br/laboratorios/lapa/versaoportugues/2c60a.pdf

FREUD, S. O Estranho. In: Obras Completas. Vol. 12. Tradução de Jayme Salomão. Rio de Janeiro: Imago, 1985.

Recordar, repetir e elaborar. Trad. Paulo C.L. Souza. Jornal de Psicanálise, São Paulo, 27(51): págs. 125-136, jul. 1994

FONSECA, C.A.L. Introdução. In: PLAUTO. Os dois Menecmos. Col. Textos Clássicos. Vol. 16. Coimbra : Instituto Nacional de Investigação Científica, 1983

FOUCAULT, M. Vigiar e Punir. Petrópolis : Vozes, 2000

GADAMER, H. Verdade e método: traços fundamentais de uma hermenêutica filosófica. 3a ed. Petrópolis : Vozes, 1997.

GAGNEBIN, J.M. Lembrar, Escrever, Esquecer. São Paulo : Ed. 34, 2006.

Prefácio. In: BENJAMIN, W. Obras Escolhidas: Magia e Técnica, Arte e Política. São Paulo : Brasiliense, 1985

Le printemps adorable a perdu son odeur. In ALEA, vol. 9, no 1, Janeiro-Junho de 2007

Do conceito de mímesis no pensamento de Adorno e Benjamin. Texto apresentado no Ciclo de Conferências sobre a Escola de Frankfurt, realizado na Faculdade de Ciências e Letras da UNESP, Campus de Araraquara, em 1990. Perspectivas, São Paulo, 16: 67-86, 1993

GANCHO, C.V. Como analisar narrativas. $8^{\mathrm{a}}$ ed. revista. Série Princípios. São Paulo : Ática, 2004 
GATTI, L. Constelações - Crítica e verdade em Benjamin e Adorno. São Paulo : Loyola, 2009

GOETHE, J.W.W.V. Truth and Poetry: from my own life. Trad. John Oxenford. Londres: Thirteen Books, 1848 Máximas e Reflexões, trad. de José M. Justo. In: Obras

Escolhidas de Goethe, vol.5. Lisboa : Círculo de Leitores, 1992

GUATIMOSIM, B.M.B. O belo e o sublime. Psicanálise \& Barroco em Revista v.6, n.3: 48-59, jul.2008

GUATTARI, F. Máquina Kafka. Trad. Peter Pál Pelbart. São Paulo/Helsinki : $\mathrm{n}-1,2011$

GUATTARI, F; ROLNIK, S. Micropolítica: Cartografias do desejo. $2^{\mathrm{a} a}$ Ed. Petrópolis : Vozes, 1986

HARMAN, M. "Digging the Pit of Babel": Retranslating Franz Kafka's "Castle". New Literary History, Vol. 27, No. 2, Problems of Otherness: Historical and Contemporary (Spring, 1996), pp. 291-311. The Johns Hopkins University Press. Disp. Em http://www.jstor.org/stable/20057354. Acesso em 07/02/2011 12:36

HEGEL, G.F.W. Cursos de Estética. Vol I e II. Trad. Marco Aurélio Werle. São Paulo : EdUSP, 2001.

HORKHEIMER, M. Eclipse da Razão. $7^{a}$ edição. São Paulo : Centauro, 2007

HUBNER.B. Franz Kafka, A Metamorfose - possíveis leituras. Disp no site www.filologia.org.br/iiijnlflp/textos_completos, p.1-14. s/d.

HULLOT-KENTOR, R. Translator's introduction. In: ADORNO, T. Aesthetics Theory. Londres : Continuum, 2002

JESUS, R. Die Werwandlung (A Metamorfose): refazendo o caminho de Kafka. Revista Garrafa, no 25. Set-dez 2011. UFRJ

JANOUCH, G. Conversations with Kafka. New York : WW Norton \& Company, 1971

KAFKA, F. A Metamorfose. Trad. Modesto Carone. $2^{a}$ edição. São Paulo : Companhia das Letras, 2003

Essencial. Trad., seleção e comentários de Modesto Carone. São Paulo : Penguin Classics/ Companhia das Letras, 2011 34,2003

O Desaparecido. Trad. Susana Kampff Lages. São Paulo : Ed. 
Discurso sobre a língua iídiche. In: Obras Completas. Lisboa/Madri : Editorial Teorema - Visión Libros, 1983

, El Proceso. Biblioteca virtual Librodot, 2002

Letras, 2000

O Processo. Trad. Modesto Carone. São Paulo: Companhia das

O Processo. Tradução, organização, prefácio, glossário e notas de Marcelo Backes. Coleção L\&PM Pocket. Porto Alegre : L\&PM, 2004

O Processo. Trad. Gervásio Álvaro. 4a edição. Colecção dois mundos. Lisboa: Livros do Brasil, 1999

O veredicto \& $\mathbf{~ N a}$ colônia penal, trad. de Modesto Carone, $3^{a}$ edição, São Paulo : Brasiliense, 1991

Um médico rural: pequenas narrativas. Trad. Modesto Carone. 4a reimp. São Paulo: Companhia das Letras, 2010

Contemplação/O Foguista. Trad. Modesto Carone, São Paulo : Companhia das Letras, 1999

Carta ao Pai. Trad. Modesto Carone. São Paulo : Companhia das Letras, 2003

Um Artista da Fome/A Construção. Trad. Modesto Carone. São Paulo: Companhia das Letras, 2000

Parábolas e Fragmentos. Prefácio e tradução: João Barrento. Lisboa: Assírio \& Alvim, 2004

, Carta ao Pai. Tradução, organização, prefácio, glossário e notas de Marcelo Backes. Coleção L\&PM Pocket. Porto Alegre : L\&PM, 2004

The blue octavo Notebooks. EUA : Exact Change, 2004. Disp. em https://docs.google.com/document/d/1gD981HZ190BUJF3czZNX3DsFWvqp3cq-Z4QS4d-9gw/edit?hl=en

O abutre e outras histórias. Tradução Noémia Ramos, rev. Francisco Silva Pereira. Colecção Resgatados. Cascais: Estrofes \& Versos, 2009

Diarios 1910-1923. Ed. Max Brod. Trad. Feliu Formosa. Colección Fabula. Barcelona : Tusquets, 1995

Die Verwandlung. Acessado em 08/fev/2011. DigBib.org. Disp. em NDAL8PCAG/www/digbib.org/Franz_Kafka_1883/Die_Verwandlung

KANT, I. Crítica da Faculdade do Juízo. Trad. Valério Rohden e Antônio. Marques. $2^{a}$ ed. Rio de Janeiro: Forense Universitária, 2008

KATE, C. Towards minor theory. Environment and Planning D:Society and Space, vol. 14, pp 487-499. New York, 1996

KESTLER, I.M.F. "O conceito de literatura universal em Goethe", in Revista Cult, ed. 130, $2010 . \quad$ Disp. em http://revistacult.uol.com.br/home/2010/03/o-conceito-de-literaturauniversal-em-goethe/

KLEIN, V. Inquietante política. Revista Tempo Freudiano, 2009. Disp. http://www.tempofreudiano.com.br/artigos/detalhe.asp?cod=65 
KLEINES

TASCHENWÖRTERBUCH

DEUTSCH-PORTUGIESISCH

(Dictionnaires Garnier). Org R.de Mesquita. Rio de Janeiro / Paris : H. Garnier, s/d

KONDER, L. Kafka - vida e obra. $5^{a}$ edição. São Paulo : José Álvaro Editor / Paz e Terra, 1974.

KORFMAnN, M. A respeito do Processo de Kafka. Revista Contingentia, v.4, no1, 2009. UFRGS. Acesso em 26.dez.2012 às 17h49. Disp. em http://seer.ufrgs.br/contingentia/article/view/8650/5022

KORFMANN, M / KEPLER, F. A literatura e o cinema como novo medium artístico: Hanns Heinz Ewers e 0 estudante de Praga (1913). Revista Pandaemonium germanicum, 12a ed., 2008, pp. 45-64. Disp. Em www.fflch.usp.br/dlm/alemao/pandaemoniumgermanicum. Acesso em 07/09/2012 às 15:35

KRIPS, H. A Mass Media Cure for Auschwitz: Adorno, Kafka and Zizek. International Journal of Žižek Studies, Vol 1, No 4 (2007). Disp http://zizekstudies.org/index.php/ijzs/article/view/67

LAGES, S. K. O Enigma Compartilhado. Revista Cult, 12/03/2010

2002

Walter Benjamin: tradução e melancolia. São Paulo : EdUSP,

LEMOS, C.A., A imitação em Aristóteles. Revista Anais de Filosofia Clássica, vol. 3 no 5, 2009.

LOWY, M. Franz Kafka: sonhador insubmisso. Rio de Janeiro : Azougue Editorial, 2005

Franz Kafka e o socialismo libertário. Disp. http://pt.protopia.at/wiki/Franz_Kafka_e_o_socialismo_libert\%C3\%A1rio \#cite_note-14

Apresentação, in COUTINHO, C.N., Lukács, Proust e Kafka. Rio de Janeiro: Civilização Brasileira, 2005

LUKACS, G. Realismo critico hoje. Trad. Ermínio Rodrigues. Introdução por Carlos Nelson Coutinho. Brasília : Coordenada-Editora de Brasília, 1969

La signification présente du réalisme critique. Les essais XVC. Trad. Maurice de Gandillac. Paris : Gallimard, 1960

34,2000

A Teoria do romance. Coleção Espírito Crítico. São Paulo : Ed.

Franz Kafka or Thomas Mann? in CRAIG, D. (org) Marxists on Literature: an anthology. New York : Penguin Books, 1975

LYOTARD, J-F. O Inumano: considerações sobre o tempo. $2^{\mathrm{a}}$ edição. Lisboa : Editorial Estampa, 1997 
MACHADO, R. Deleuze: a Arte e a Filosofia. Rio de Janeiro : Jorge Zahar Editor, 2009

MALDONADO, M. El Expresionismo y las vanguardias en la literatura alemana. Madrid : Síntesis, 2006

MAQUIAVEL, N. O Príncipe. Comentado por Napoleão Bonaparte. São Paulo : Martin Claret, 2008

MARANHÃO, H.P. Entre Kafka e Foucault: anotações do poder no "corpo disciplinado". Revista Aulas - Dossiê Foucault. No 3 - dezembro de 2006/março de 2007. Unicamp. Campinas, 2007

MARTINeZ, V. Estado K. ou o Povo dos Camundongos. Simpósio "Estranhamento e sociabilidade: uma análise crítica de O Processo de Franz Kafka". UNESP-Marília, 07/10/2005. Disp. http://www.sociologiajuridica.net.br/lista-de-publicacoes-de-artigos-etextos/45-direito-e-ficcao-/127-estado-k-ou-o-povo-dos-camundongos-

MARTINS, N.S. Introdução à estilística. $4^{a}$ edição revista. São Paulo, EdUSP, 2008

MASSARA, G. O estético e o ético na psicanálise: Freud, o sublime e a sublimação. Tese de doutorado. Orientação Prof.Dr. Vladimir Pinheiro Safatle. São Paulo : USP, 2010. Disp. Em www.fflch.usp.br/df/site/.../2010.../2010.mes_guilherme_massara.pdf

MICHAELIS MODERNO DICIONÁRIO ESCOLAR da Língua Portuguesa. 7aa ed. São Paulo : Melhoramentos, 2010. Disp. em http://michaelis.uol.com.br/moderno/portugues/index.php

MORAES, A. L. Sobre a negatividade do conceito de indivíduo em Adorno: a resistência possível. Psicol. USP [online]. 2006, vol.17, n.3 [citado 2012-10-14], pp. 127-144. Disponível em: $<$ http://www.revistasusp.sibi.usp.br/scielo.php?script=sci_arttext\&pid=S1 678-51772006000300010\&lng=pt\&nrm=iso >. ISSN 1678-5177.

MUSSE, R. A Dialética como método e filosofia no último Engels. Revista Crítica Marxista no. 05, pp. 40-54. São Paulo: Xamã, 1997.

NESBITT, N. The Expulsion of the Negative: Deleuze, Adorno, and the Ethics of Internal Difference - Revista SubStance - Ed.107 (Volume 34, Number 2), 2005, pp. 75-97. University of Wisconsin Press. Disp. http://muse.jhu.edu/login?uri=/journals/substance/v034/34.2nesbitt.html 
NOYAMA, S. Adorno e o "ensaio como forma". Revista Itaca, no 14, UFRJ, 2009. Disp. www.revistaitaca.org/versoes/vers14-09/135-147.pdf

OXFORD KAFKA RESEARCH CENTRE. Portal. http://www.kafkaresearch.ox.ac.uk/index.php

PEQUENO DICCIONARIO PORTUGUEZ-ALLEMÃO (Dictionnaires Garnier). Org R.de Mesquita. Rio de Janeiro / Paris : H. Garnier, s/d

PAWEL, E. O pesadelo da Razão: a vida de Franz Kafka. Trad. Vera Ribeiro. Rio de Janeiro : Imago, 1986

PELBART, P.P. Da Clausura do Fora ao fora da clausura: loucura e Desrazão. São Paulo : Brasiliense, 1989

A bordo de um veleiro destroçado, in GUATTARI, F. Máquina Kafka. São Paulo/Helsinki : $n-1,2011$

A vertigem por um fio: políticas da subjetividade contemporânea. São Paulo : Iluminuras, 2000

PELLEJERO. E, Literatura e fabulação: Deleuze e a política da expressão. Trad. Susana Guerra. Polymatheia - Revista de Filosofia, vol IV, no 5, pp 61-78. Fortaleza, 2008.

PEREIRA, M. Barroco, símbolo e alegoria em Walter Benjamin. Revista Analecta, v. 8, no 1, p. 11-18. Jan-jun 2007

PODDIS, J. G., Os insetos e o homem na literatura e no cinema: uma metamorfose. Anais do SILEL. Volume 1. Uberlândia: EDUFU, 2009.

POE, E. A. Poemas e Ensaios. Trad. Oscar Mendes e Milton Amado. $3^{a}$ edição revista. São Paulo: Globo, 1999.

PUCCI, B. Para Rosa com Adorno: a luta agônica da palavra e do conceito em busca do "quem" das coisas. Revista Artefilosofia n. 08, abril de 2010, p.122-133

RANCIÈRE, J. Será que a Arte resiste a alguma coisa? Artigo disponível

em

http://www.rizoma.net/interna.php?id=316\&secao=artefato. Publicado em $17 / 12 / 2008$. Acessado em 17/03/2009 às $14: 01 \mathrm{~h}$

ROBERTSON, R. Kafka: a very short introduction. Oxford : Oxford University Press, 2004

ROSENFIELD, K. Walser por Xerxenesky, Joca Terron e Kathrin Rosenfield.

Disp. em

http://oglobo.globo.com/blogs/prosa/posts/2011/04/02/walser-porxerxenesky-joca-terron-kathrin-rosenfield-372501.asp 
SÁ, M.C. Da literatura fantástica (teorias e contos). Dissertação de mestrado em Teoria Literária e Literatura Comparada. 2003 : FFLCH/USP. Orientadora. Profa. Dra. Sandra Margarida Nitrini. Disp. em http://www.teses.usp.br/teses/disponiveis/8/8151/tde-23102003190256/publico/TeseMarcioSa.pdf. Acesso em 21/10/2011

SAFATLE, V. Para introduzir a experiência intelectual de Theodor Adorno. In: ALMEIDA, J.; BADER, W., Pensamento alemão contemporâneo. São Paulo: Cosac e Naify, 2009.

Espelhos sem imagens: mimesis e reconhecimento em Lacan e Adorno. Trans/Form/Ação, Marília, v. 28, n. 2, 2005 . Available from <http://www.scielo.br/scielo.php?script=sci_arttext\&pid=S0101$31732005000200002 \& \mid n g=e n \& n r m=$ iso $>$ access on 01 Dec. 2011. http://dx.doi.org/10.1590/S010131732005000200002

Trópico, 2002

Pós-modernidade: utopia do capitalismo. Revista Virtual

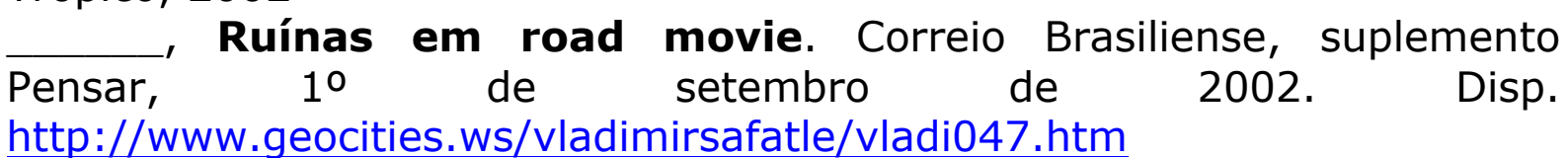
, Linguagem e negação: sobre as relações entre pragmática e ontologia em Hegel. Revista doispontos, Curitiba/São Carlos, vol. 3, n. 1, p.109-146, abril, 2006

SANTOS, P.S. Benjamin e Adorno: considerações ao redor de Kafka. Tempo da Ciência (UNIOESTE), v. 15, p. 147-157, 2008

(Im)possibilidades na literatura de Franz Kafka. Dissertação de mestrado em Sociologia. FFLCH/USP. Orientador: Prof. Dr. Leopoldo Waizbort. Disp. $\mathrm{Em}$ www.teses.usp.br/teses/disponiveis/8/.../PATRICIA_SILVA_SANTOS.pdf

SANTOS, T.B. Tecnologia e media óticos em Franz Kafka. Dissertação de Mestrado em Literatura Comparada. Orientação Prof. Dr. Michael Korfmann. UFRGS. Porto Alegre, 2010. Disp. em www. lume.ufrgs.br/bitstream/handle/10183/.../000749333.pdf?...1

SARTRE, J-P. Que é a Literatura? $3^{\mathrm{a}}$ ed. $3^{\mathrm{a}}$ impressão. São Paulo : Ática, 2006

SCHLHESENER, A. Mímesis e infância: observações acerca da educação a partir de Walter Benjamin. São Leopoldo : UNISINOS, 2009

SELIGMANN-SILVA, M. Adorno. Coleção Folha Explica. São Paulo : Publifolha, 2009 
e Coetzee. Congresso Mal-estar na Cultura / Abril-Novembro de 2010. Departamento de Difusão Cultural - PROREXT-UFRGS; Pós Graduação em Filosofia - IFCH - UFRGS. Disp. em: http://.difusaocultural.ufrgs.br\%2Fadminmalestar\%2Fdocumentos\%2Farq uivo\%2FMarcioSeligmannSilva.pdf

SERCEAU, M. De la littérature au cinema, de Kafka à Orson Welles. Un exemple d'adaptation-interprétation: Le Procès. Association des Professeurs de lettres (site). Disp. Em http://www.aplettres.org/de_Kafka_a_Orson_Welles.pdf

SHOLLE, D. The Subject of Adorno. Palestra. International Communication Association. Disp. http://www.allacademic.com/meta/p112007_index.html. Acesso em 26/11/2008.

SCHOLLHAMMER, K. As práticas de uma língua menor: reflexões sobre um tema de Deleuze e Guattari. Revista Ipotesi, Juiz de Fora, 2002

SCOTT, J. O enigma da igualdade. Revista Estudos Feministas, Florianópolis, 13(1): 216, janeiro-abril/2005- Disp. em http://www.scielo.br/pdf/ref/v13n1/a02v13n1.pdf

SILVA, F.L. Bergson: intuição e discurso filosófico. São Paulo : Loyola, 1994

SILVA, H. Os filmes desnarrativos de David Lynch. São Paulo : Revista Trópico, $2008 . \quad$ Disp. Em http://pphp.uol.com.br/tropico/html/textos/2999,2.shl

SOUZA, L. S., Avessos da dialética: Adorno, Lukács e o realismo no século XX. Revista Verinotio, no 12, ano VI, out/2010. Disp. em http://www.verinotio.org/

TADEU, T. Deleuze e a questão da literalidade: uma via alternativa. Educ. Soc., Campinas, vol. 26, n. 93, p. 1331-1338, Set./Dez. 2005. Disponível em http://www.cedes.unicamp.br

TELLAROLI, S. Entrevista in CARVALHO, P. Visionário de pequenas coisas (resenha sobre a obra Jakob Von Gunten, de WALSER). Diário de Pernambuco, edição de 22 de abril de 2011

THEODOR ROSENTHAL, E. Introdução à Literatura Alemã. Rio de Janeiro : Ao Livro Técnico, 1968.

THOBURN, N. Deleuze, Marx and Politics. Routledge Studies in Social and Political Thought. Londres : Routledge, 2003. 
TIBURI, M. Crítica da razão e mímesis no pensamento de Theodor W. Adorno. Porto Alegre : EDPUCRS, 1995

TRAGTENBERG. M. Franz Kafka - Romancista do Absurdo. in Revista Alfa, no 1. F.F.L.C. Marília. Marília, 1962

TRONCA, F.Z. O estilo enquanto lógica de identificação: elo entre as características expressivas complexas que se coadunam no trânsito do processo histórico e a manifestação expressiva particular e singular de um indivíduo. E-periódico ModaPalavra Ano 1, n.2, ago-dez 2008, pp. $60-68$. ISSN 1982-615x

TODOROV, T. Introdução à Literatura Fantástica: Teoria da Literatura. Debates. São Paulo : Editora Perspectiva, 2008.

VIRTANEN, A. O discreto charme do precariado, in GUATTARI, F. Máquina Kafka. São Paulo/Helsinki : n - 1, 2011

WALLACE, D.F. Laughing with Kafka. Conferência no simpósio Metamorphosis: a new Kafka. PEN American Center. Nova Iorque, 1998. Publicada em Harper's Magazine, edição de jul/1988

ZILCOSKY, J. Kafka's Travels: Exoticism, Colonialism, and the Traffic of Writing. Palgrave Macmillan, Nova Iorque : 2003. Disp. em http://books.google.com.br/books?id=-

TZVKQFicTEC\&printsec $=$ frontcover\&hl $=p t-B R \# v=$ onepage $\& q \& f=$ false

ZISCHLER, H. Kafka vai ao cinema. Trad. Vera Ribeiro. Rio de Janeiro : Jorge Zahar Editor, 2005 